


\section{Combating organized crime}

\section{A study on undercover policing and the follow- the-money strategy}


ISBN: 9789053832288

Thesis layout and cover design: proefschrift-aio.nl

Copyright: (C) 2017, Edwin W. Kruisbergen 


\section{COMBATING ORGANIZED CRIME A STUDY ON UNDERCOVER POLICING AND \\ THE FOLLOW-THE-MONEY STRATEGY}

\section{ACADEMISCH PROEFSCHRIFT}

ter verkrijging van de graad Doctor aan de Vrije Universiteit Amsterdam, op gezag van de rector magnificus prof.dr. V. Subramaniam, in het openbaar te verdedigen ten overstaan van de promotiecommissie van de Faculteit der Rechtsgeleerdheid op maandag 9 januari 2017 om 15.45 uur in de aula van de universiteit, De Boelelaan 1105

door

\section{Edwin William Kruisbergen}

geboren te "s-Gravenhage 
promotoren:

prof.dr. E.R. Kleemans

prof.mr.dr. M.J. Borgers 
Thesis committee: $\quad$ prof. N. Fyfe prof.dr. W. Huisman prof.mr. T. Kooijmans prof. M. Levi prof.dr. P. Ponsaers 



\section{Contents}

1 General introduction 11

1.1 The rise of organized crime on the political agenda 11

$\begin{array}{ll}\text { 1.1.1 Organized crime in the Netherlands } & 12\end{array}$

$\begin{array}{ll}1.2 \text { Combating organized crime } & 13\end{array}$

$\begin{array}{ll}\text { 1.2.1 The criminal justice approach } & 14\end{array}$

$\begin{array}{ll}\text { 1.2.2 The financial approach } & 18\end{array}$

1.3 Research on counterstrategies to organized crime 23

1.4 Purpose and research questions of this thesis 25

$\begin{array}{ll}1.5 \text { Empirical data } & 27\end{array}$

1.6 Outline of this thesis 32

2 Undercover policing: assumptions and empirical evidence 33

2.1 Introduction 33

2.2 Undercover operations: a brief history 34

2.3 Academic and legislative debate: theory and assumptions 36

2.3.1 Academic debate 36

$\begin{array}{lll}\text { 2.3.2 Legislative debate } & 37\end{array}$

2.3.3 Assumptions in academic and legislative debate 39

2.4 Current Study 40

2.5 Undercover operations in the Netherlands: numbers, types, course and results 41

2.5.1 Numbers 41

2.5.2 Types 41

$\begin{array}{ll}\text { 2.5.3 Measuring success and failure } & 42\end{array}$

2.5.4 The unpredictable criminal environment 45

2.6 Undercover operations and the court 47

2.7 Discussion 48

3 Infiltrating organized crime groups: theory, regulation and results of a last resort method of investigation $\quad 53$

3.1 Introduction 53

3.2 Undercover policing 55

3.2.1 Policing organized crime 56

3.2.2 Undercover policing in historical perspective: from Judas to 'Mr. Big' 58

$\begin{array}{ll}3.3 \text { Regulation of undercover policing } & 60\end{array}$

$\begin{array}{ll}\text { 3.3.1 Affairs and legislative debate } & 61\end{array}$ 
3.3.2 Regulation in the Netherlands

$\begin{array}{ll}3.4 \text { Current study } & 64\end{array}$

3.5 Infiltration operations in the Netherlands 66

3.5.1 The assessment of proposed infiltration operations by the Central Assessment Committee (CTC) and the Board of Procurators General 66

3.5.2 In which cases and on what grounds does a public prosecutor opt for an infiltration operation? $\quad 67$

3.5.3 Course and results of infiltration operations 68

3.6 Analysis: unpredictability and regulation of undercover operations 71

3.6.1 Unpredictability, the consequence of participating in illegal markets 71

3.6.2 Implementation of regulatory procedures in the investigative practice $\quad 73$

3.7 Discussion 77

4 Profitability, power, or proximity? Organized crime offenders investing their $\begin{array}{ll}\text { money in legal economy } & 79\end{array}$

4.1 Introduction $\quad 80$

$\begin{array}{lll}4.2 & \text { Theoretical perspectives and empirical research } & 81\end{array}$

$\begin{array}{lll}\text { 4.2.1 Theoretical perspectives } & 81\end{array}$

4.2.2 Empirical research $\quad 82$

$\begin{array}{ll}4.3 \text { Methodology } & 84\end{array}$

$\begin{array}{lll}4.3 .1 & \text { Definition } & 84\end{array}$

$\begin{array}{ll}\text { 4.3.2 Data and methods } & 84\end{array}$

4.4 Results: investments of organized crime $\quad 85$

4.4.1 Investments: property and companies $\quad 86$

$\begin{array}{lll}\text { 4.4.2 Scope of investments } & 92\end{array}$

4.5 Conclusion and discussion $\quad 97$

$\begin{array}{lll}\text { 4.5.1 Empirical results } & 97\end{array}$

4.5.2 Profitability, power, or proximity? 97

$\begin{array}{lll}\text { 4.5.3 Implications } & 99\end{array}$

5 Explaining attrition: investigating and confiscating the profits of organized $\begin{array}{ll}\text { crime } & 101\end{array}$

$\begin{array}{ll}5.1 \text { Introduction } & 101\end{array}$

$\begin{array}{lll}\text { 5.1.1 Present study: purpose and research questions } & 102\end{array}$

5.2 Prior research 103

5.3 Methodology 104

5.4 Follow the money in the Netherlands:institutional framework 105 
5.6 Court procedures: from public prosecutor's claim to Supreme Court 110

5.6.1 Court procedures: determining the amount of criminal profit 111

$\begin{array}{ll}\text { 5.6.2 Court procedures: lengthy procedures } & 113\end{array}$

5.6.3 Court procedures: taking into account the convict's financial capacity 114

5.7 The collection of confiscation orders: What do they actually pay? 114

$\begin{array}{ll}\text { 5.7.1 Legal reasons to stop collection without (full) payment } & 115\end{array}$

5.7.2 Convict is unwilling to pay and succeeds in hiding his assets 116

$\begin{array}{lll}\text { 5.7.3 The convict is unable to pay } & 116\end{array}$

$\begin{array}{ll}5.8 \text { Conclusion and discussion } & 117\end{array}$

$\begin{array}{lll}\text { 5.8.1 Empirical results } & 117\end{array}$

$\begin{array}{ll}\text { 5.8.2 Explaining attrition } & 118\end{array}$

$\begin{array}{lll}5.8 .3 & \text { Implications } & 118\end{array}$

6 Conclusion and discussion $\quad 121$

6.1 This thesis: research questions, data and summary of the empirical results $\quad 121$

$\begin{array}{lll}6.1 .1 & \text { The criminal justice approach } & 121\end{array}$

$\begin{array}{ll}\text { 6.1.2 The Financial approach } & 126\end{array}$

6.2 Scope of this research and methodological considerations 130

$\begin{array}{ll}6.2 .1 & \text { Scope and limitations } \\ 6.2 .2 & 130\end{array}$

$\begin{array}{ll}\text { 6.2.2 Value of this study } & 134\end{array}$

6.3 Implications 137

6.3.1 Controlling the use of special methods of criminal investigation 137

$\begin{array}{ll}\text { 6.3.2 Crime money and the legal economy } & 141\end{array}$

6.3.3 Investigating and confiscating the proceeds of organized crime 142

6.4 Research on counterstrategies to organized crime 145

$\begin{array}{ll}\text { 6.4.1 Why should we do research on organized crime policies? } & 145\end{array}$

$\begin{array}{ll}\text { 6.4.2 Suggestions for further research } & 146\end{array}$

$\begin{array}{ll}\text { 6.4.3 Concluding remarks } & 148\end{array}$

$\begin{array}{ll}\text { References } & 149\end{array}$

$\begin{array}{ll}\text { Samenvatting (Dutch summary) } & 177\end{array}$

$\begin{array}{ll}\text { Curriculum vitae } & 199\end{array}$

$\begin{array}{ll}\text { Publications } & 201\end{array}$ 



\section{General introduction}

This thesis presents empirical evidence on two counterstrategies to organized crime in the Netherlands: the criminal justice approach and the financial approach. For the criminal justice approach, it focuses on a specific method of criminal investigation: undercover policing. For the financial approach, it looks into what organized crime offenders actually do with their money as well as the efforts of law enforcement agencies to confiscate criminal earnings.

\subsection{The rise of organized crime on the political agenda}

According to Paoli and Fijnaut, the term 'organized crime' was coined in the United States at the close of the nineteenth century (2006: 308-309). Although organized crime flourished in the early decades of the twentieth century - when criminal groups were active in the liquor trade and had control over unions and legitimate businesses - it was not until the 1950s that the phrase became really popular in the United States. Since that date, several U.S. congressional bodies have put the issue on the political agenda. These bodies viewed organized crime mainly as the work of a nationwide, centralized, Italian mafia organization. The Kefauver senate investigating committee stated in its final report: 'The public now knows that the tentacles of organized crime reach into virtually every community throughout the country' (U.S. Senate, 1951). Mafia leaders were believed to be in control of the most lucrative criminal activities. In 1963, former Mafioso Joe Valachi testified before the Senate Permanent Subcommittee on Investigations. Because his testimony was broadcasted on television, this awareness of - or view on - organized crime became popularized among the American public (Paoli and Fijnaut, 2006: 308-309; Fijnaut, 2014: 72-74).

From the 1960s onwards, illegal drugs gave an impulse to organized crime. The popularity of cannabis, heroin, cocaine and synthetic drugs have fostered a trade in drugs and stimulated the rise of distribution networks on a national as well as an international level. It brought lucrative chances for those who are capable of bridging the distance between regions where these drugs are produced and regions where consumer markets are located (Paoli and Fijnaut, 2006: 315; Van Duyne and Levi, 2005). ${ }^{1}$

For a historical overview of 'organized crime', such as banditry in seventeenth- and eighteenth-century Northwestern Europe, see Fijnaut, 2014. For a history of the concept of organized crime, see Paoli and Fijnaut, 2004a. 


\subsubsection{Organized crime in the Netherlands}

Until the 1970s, the term 'organized crime' was almost exclusively used in the United States. For a long time, Dutch criminologists and policymakers considered organized crime to be a predominantly foreign problem, similar to what their colleagues in most other European countries thought. It was not until the early 1990s that organized crime 2 reached the political agenda in the Netherlands. ${ }^{3}$ Authorities had become more aware of the huge profits made by offenders who engaged in trafficking cannabis, cocaine and heroin. The fact that, on several occasions, these criminals used deadly violence to deal with threats or to solve other problems with 'colleagues', also helped to raise the sense of urgency. On an international level, two bomb attacks in Italy in 1992, killing the prominent judges Giovanni Falcone and Paolo Borsellino, produced huge shock waves and played a significant role in putting organized crime on the European crime control agenda. In the Netherlands, in particular the killing of alleged Mafia don Klaas Bruinsma in 1991 served as a 'wake-up call' (Kleemans, 2007: 163-164; Paoli and Fijnaut, 2006: 308-309; Paoli, 2014: 1; Van Duyne and Vander Beken, 2009: 265-266).

The organized crime problem became a hot topic on the Dutch political agenda. In the early 1990s, the dominating view on organized crime was that of the Mafia-type organizations that existed in Italy and the United States. The problems with the mafia in Italy and the United States, where mafia organizations controlled certain economic sectors or regions, functioned as a powerful symbol of what could happen to the Netherlands as well. ${ }^{4}$ Empirical research showed, however, that this picture actually contradicted the phenomenon of organized crime in the Netherlands. Mafia-type organizations were found to be the exception rather than the rule. The concept of criminal networks turned out to be a better-fitting description of the flexible structures within which offenders operate. Furthermore, no evidence was found of criminal organizations controlling economic sectors or regions (Kleemans, 2007: 163-164; Kleemans, 2004, 2014b; Van de Bunt, 2004: 689).

Many forms of organized crime in the Netherlands can be described as 'transit crime', i.e. criminal groups are primarily involved in international illegal trade. The major business

2 Following the work of Fijnaut et al. (1998: 26-27), organized crime is defined as crime committed by groups that primarily focus on illegal profit, systematically commit crimes that adversely affect society, and are capable of effectively shielding their activities, in particular by being willing to use physical violence or eliminate individuals by way of corruption. One of the main sources of information for this thesis, the Dutch Organized Crime Monitor, uses a wide interpretation of shielding of activities. Besides (the threat of) violence and corruption, it includes the use of cover businesses, code language, counter-surveillance activities, and the misuse of certain occupational groups, such as notaries, public lawyers and accountants (Kleemans et al., 1998: 22-23; Van Koppen, 2013a: 1).

3 The same is true for many other European countries with the exception of Italy.

4 This view was clearly present in a memorandum issued by the Dutch government in 1992. According to the memorandum, titled 'Organized Crime in the Netherlands: An Impression of Its Threat and a Plan of Action' (Ministerie van Justitie/Ministerie van Binnenlandse Zaken, 1992), organized crime posed a major threat to the integrity of Dutch society; economic sectors and political institutions were at risk of being infiltrated by organized crime (Kleemans, 2007: 163-164). 
of organized crime groups in the Netherlands boils down to international smuggling activities. In these activities, the Netherlands can be a country of destination, a transit country or, in the case of cannabis and synthetic drugs, a production country. In these types of crime, offenders simply make use of the legal opportunities, such as the economic and physical infrastructure, instead of trying to monopolize it. The Netherlands is an important logistical node in Europe, which brings good opportunities for international trade, be it legal or illegal. The logistical attractiveness is probably one of the causes of the Netherlands being a major transit country for drugs. Besides the physical infrastructure, the Netherlands also provides a good social opportunity structure for international drug trafficking. Migration has created strong social ties with drug-producing or exporting countries (or islands) such as the Antilles, Morocco, Surinam and Turkey (European Monitoring Centre for Drugs and Drug Addiction, 2015; Fijnaut et al., 1998; Kleemans, 2007: 163-164; Kleemans, 2004, 2014b; United Nations Office on Drugs and Crime, 2015; Van de Bunt, 2004: 689).

\subsection{Combating organized crime}

The rise of organized crime confronted authorities with challenges, challenges that were met with 'new' strategies in crime control. On the one hand, a shift took place within the criminal justice approach. The criminal justice approach was - and perhaps still is - the most dominant where fighting crime is concerned. It basically boils down to policing, arresting and prosecuting offenders. Because of the consensual nature of several types of organized crime, traditional, reactive policing methods became less adequate. This led to a shift from reactive methods of criminal investigation to proactive methods (Harfield, 2008: 64; Roberts, 2007: 99; Maguire and John, 1996: 316-318; Fyfe and Sheptycki, 2006: 319-320; Paoli and Fijnaut, 2004b: 1043). Furthermore, policymakers and others involved in the crime debate became convinced of the need for an additional approach to organized crime, a financial approach. This was fuelled by growing concern with regard to the money made by offenders and the effects 'dirty money' could have on society as a whole. As a result, an array of anti-money laundering policies and confiscation laws were introduced worldwide (Gallant, 2005: 11). The rise of (certain kinds of) proactive methods of criminal investigation as well as the introduction of a financial approach, were in large part instigated by U.S. policies. Both approaches will be elaborated upon below. ${ }^{5}$

\footnotetext{
Later on, a third approach to organized crime emerged; the so-called administrative approach. This approach, inspired by initiatives of New York authorities in the 1990s, is now a widely accepted and acclaimed counterstrategy to organized crime in the Netherlands. The administrative approach involves local governments and other partners in fighting and preventing organized crime. On a national level, the approach was manifested in 2003, when the Bibob Act came into effect. Bibob stands for the Wet bevordering integriteitsbeoordelingen door het openbaar bestuur, which translates as the Public administration probity screening Act (Stb. 2014, no. 445). The act provides a legal basis for authorities to refuse or withdraw permits, licenses, grants and subsidies in case of a serious threat of criminal abuse (Van de Bunt and Van der Schoot, 2003; Ayling, 2014; Beare and Woodiwiss, 2014: 565; Paoli and Fijnaut, 2006: 326; Kleemans, 2007; Van der Vorm, 2016).
} 


\subsubsection{The criminal justice approach}

Roughly from the 1960s onwards, as was explained in the first section, drug trafficking gave a powerful impulse to organized crime activities around the world. People involved in these activities (often) participate with mutual consent. The wholesale drug trafficker, the truck driver who transports the drugs from a port to a stash, the street-level drug dealer and his customers, and the money mule who moves 'dirty' cash; they all benefit from their participation. ${ }^{6}$ The same holds for people involved in the illegal arms trade, illegal gambling and underground banking, among other organized crime(-related) activities. Therefore, unlike traditional crimes such as burglary, robbery or rape, for that matter, organized crime does not generate victim reports. This means that reactive policing is becoming increasingly inadequate, as it is primarily instigated by victim reports, and criminal events and behaviour in the past. For this reason, policing organized crime (also) requires the use of proactive investigative methods. Proactive policing focuses on gathering evidence about the current and future behaviour of offenders. It includes methods of investigation such as wiretapping, surveillance, the use of informers and undercover policing. ${ }^{7,8}$

\section{Undercover policing}

Wiretapping, surveillance, the use of informers and undercover policing have a common feature; they are all covert methods of investigation. Subjects are unaware of their use, as opposed to police activities such as arrests, house searches and interrogations, which cannot be deployed without subjects knowing it. However, in contrast to wiretapping and surveillance, undercover operations are not only covert but also deceptive (as is the use of informers). An undercover agent hides his true identity, poses as a 'fellow criminal', for example, tries to gain the subject's trust, and uses his cover to gather information on the subject or people in his surroundings. Another distinctive characteristic of undercover operations is that, in some cases at least, undercover agents participate in the very crimes that are under investigation (Marx, 1988: 11-13; Ross, 2008: 239). Such is the case in operations, for instance, in which an undercover agent participates in a criminal group involved in drug trafficking. These specific features bring with them certain investigative opportunities as well as certain risks. They are probably also an important reason why

${ }^{6}$ Some people might be forced to cooperate. However, due to the opportunity to earn 'quick money' (or, as is the case for customers, the opportunity to satisfy the need for drugs), there are many willing perpetrators.

7 These methods of investigation are also applied in reactive criminal investigations. Undercover operations, for example, have been used to elicit confessions from suspects in investigations regarding murder and missing people, among other crimes (see chapters 2 and 3 ).

8 Strictly speaking, the use of the phrase 'proactive' is incorrect since, in many cases of proactive investigations, there is information indicating that crimes already have been committed. However, in a proactive investigation, the police (also) focus on criminal activities that are still ongoing or still have to be committed, for instance on offenders who have probably participated in drug trafficking operations in the past and are expected to continue these crimes (see also Tweede Kamer, 1996-1997, 25 403, no. 3: 4). 
undercover policing is one of the most controversial methods of criminal investigation and has been the subject of heated legislative debate. ${ }^{9}$

Undercover methods are certainly not a twentieth-century invention. Undercover tactics, in different manifestations and with different purposes, have been used for centuries (see chapter 3 for a brief historical overview). However, their deployment became more prominent when, in the 1960 s, the fight against drug trafficking rose on the agenda. Law enforcement agencies in the United States deployed undercover operations on a large scale, mainly in the form of so-called buy-bust operations. In such an operation, an undercover agent poses as someone who wants to buy drugs (for example). As the 'war on drugs' became part of U.S. foreign policy, the American Drugs Enforcement Administration (DEA) exported these operations to Western Europe (Ross, 2008: 241; Fijnaut and Marx, 1995a: 15-16; Van Duyne and Levi, 2005: 19).

Accompanying this criminal justice approach to organized crime, institutional reforms were implemented in many countries. These reforms concerned setting up new police units and the regulation of methods of investigation such as undercover policing (Paoli, 2014: 2; Paoli and Fijnaut, 2006: 325-326; Van der Tak, 2000: 1). On the one hand, these changes were introduced to facilitate the fight against organized crime. On the other hand, they are meant to enhance the control of police activities, as policing is increasingly being subjected to formal statutory regulation (Newburn et al., 2007: 547-548; Roberts, 2007: 97-102; Groenhuijsen and Kooijmans, 2011: 62). Specific criminal cases, incidents and outright scandals often served as driving forces behind the legislative debate on investigative powers.

In the United Kingdom, the Khan case played an important role in the regulation of police powers (see chapter 2), while in Belgium, undercover policing became discredited as a result of the so-called François scandal, and in the United States a controversy emerged around the Abdul Scam (see chapter 3). The course of the legislative debate in the Netherlands was defined by the IRT affair. Undercover operations gave cause for this affair, which in turn ultimately resulted in a major legal reform with regard to investigative powers.

\section{Undercover policing in the Netherlands}

Interregional investigation squads (IRTs), joint investigation teams put together from several regional police forces, were established in response to growing concerns about organized crime in the 1990s. The IRTs deployed 'experimental' investigative methods against criminal groups involved in large-scale international drug trafficking. Informers

\footnotetext{
Historical, social or cultural characteristics of a country may also result in a critical attitude towards undercover operations. In post-war Europe, for example, undercover methods were initially discredited, due to the intensive use the national-socialist Third Reich and the communist Soviet Union had been making of government espionage against their own populations (Marx, 1988: 22-32).
} 
imported several tons of drugs under the supervision of the police. The informers, themselves criminals, were assisted by the police and customs to pose as trustworthy and successful criminal entrepreneurs, in the hope that they would move to the top of criminal organizations. Internal disputes, however, led to the sudden dismantling of the AmsterdamUtrecht IRT in 1993. This 'IRT affair' resulted in the appointment of fact-finding committees and, eventually, in a full-fledged Parliamentary Inquiry Committee on Criminal Investigation Methods (in Dutch: Parlementaire Enquêtecommissie Opsporingsmethoden (PEO)).

The committee concluded that some of the new policing methods were unacceptable. It questioned whether the police were running the informers or vice versa. Overall, criminal investigation in the Netherlands, according to the committee, suffered from three fundamental flaws. First, the committee concluded that there was a legal vacuum regarding certain investigative methods. In continental European jurisdictions belonging to civil law systems, such as the Dutch one, the exercise of police powers requires a formal basis in the national police law or code of criminal procedure (Roberts, 2007: 96). However, until 2000, there were no specific sections in the Dutch code of criminal procedure that covered investigative methods such as undercover policing and surveillance. Second, the organization of the criminal justice system was found to be inadequate. Third, the command and control of criminal investigations was poor (PEO, 1996, Eindrapport).

The committee's report, published in 1996 (PEO, 1996, Eindrapport), provided the foundation for the new Act on Special Investigative Police Powers (in Dutch: Wet bijzondere opsporingsbevoegdheden (BOB Act)), effective as from 2000 (Kleemans, 2007: 164-165). ${ }^{10}$ The BOB Act - addressing the aforementioned fundamental flaws regarding criminal investigation - is built on three basic principles. First, methods of criminal investigation that are likely to involve a breach of fundamental human rights or pose a risk to the integrity of the officers conducting the criminal investigation, should have a statutory basis. The BOB Act regulates several methods of criminal investigation. Since the act came into effect, most investigative powers are covered by specific sections in the code of criminal procedure. Second, the public prosecutor has the authority over a criminal investigation. The BOB Act enhances the role of the public prosecutor in the criminal investigation process. The public prosecutor formally decides on the use of investigative powers (Bokhorst et al., 2002: 185-186). ${ }^{11}$ Third, the deployment of methods of criminal investigation should be verifiable and therefore transparent. The BOB Act prescribes that a report is made of the used methods of investigation. Furthermore, in principle, the

\footnotetext{
10 Act on Special Investigative Police Powers (Wet bijzondere opsporingsbevoegdheden, complete reference in Dutch: Wet van 27 mei 1999 tot wijziging van het Wetboek van Strafvordering in verband met de regeling van enige bijzondere bevoegdheden tot opsporing en wijziging van enige andere bepalingen (bijzondere opsporingsbevoegdheden), Stb. 1999, no. 245).

11 The deployment of some methods of investigation also requires authorization of an examining magistrate.
} 
deployment of a special investigative method has to be accounted for at trial (Beijer et al., 2004: 277-278). Before the BOB Act was introduced, judges were often not even informed about the fact that an undercover operation, for example, had been deployed (Van Traa, 1997: 16).

Since the BOB Act came into effect, it is, in principle, not allowed to 'supervise' the importation of drugs, as the IRT did. Illegal goods or substances that constitute a risk to public health or public safety, such as drugs or weapons, have to be confiscated. ${ }^{12}$ Furthermore, participation in criminal activities by police officers or by civilians working under police supervision has to comply with laws and regulations (Beijer et al., 2004: 278).

With regard to undercover operations, the Dutch legislator chose to distinguish between three powers in the BOB Act: systematic intelligence gathering, the purchase of illegal goods or substances or the rendering of illegal services (undercover buys), and infiltration. ${ }^{13}$ Infiltration is assumed to involve more risks than the deployment of an undercover buy does, which in turn is assumed to be more risky than the use of systematic intelligence gathering. During an infiltration operation, the undercover agent actually becomes a member of a criminal group. Joining a criminal organization is a crime. Furthermore, as the legislator argues, it entails the risk of moral contamination of the police officer by the criminal environment, as well as risks concerning the physical safety of the undercover agent and his relatives. During an undercover buy, an undercover agent buys illegal goods or substances from a suspect, such as weapons, child pornography or drugs. ${ }^{14}$ When an undercover agent buys such goods or substances, he also participates in a crime. However, according to the legislator, that criminal participation is less far-reaching and less sustained than is the case with infiltration. Systematic intelligence gathering is assumed to involve fewer risks than the other two undercover powers, because the undercover agent 'only' collects information and does not participate in any crimes. The legal requirements for the deployment of undercover powers correspond to the assumed level of risk attached to them. Infiltration is only allowed in investigations targeting the most severe crimes (proportionality) and only if other policing methods have proven (or are expected to be) ineffective (subsidiarity). Undercover buys and systematic intelligence gathering, however, may be deployed against a (much) broader category of crimes and without an exhaustive exploration of alternative methods of investigation.

In addition, where infiltration is concerned, further authorization requirements have to be met. After deliberation with the regional chief public prosecutor, a public prosecutor who wants to deploy an infiltration operation has to submit a substantiated proposal to the

12 Under certain conditions, seizure may be delayed.

13 Infiltration operations may involve one or several undercover buys.

14 Instead of buying illegal goods or substances from a suspect, an undercover agent may also render services to a suspect, such as when he provides transportation for a drug trafficking operation. 
Central Assessment Committee (in Dutch: Centrale Toetsingscommissie (CTC)). The CTC tests the proposed operation for proportionality and subsidiarity, among other factors. If the CTC considers the operation permissible, the proposal goes to the Board of Procurators General, where the ultimate decision is made whether the infiltration operation is allowed or not. If an infiltration operation is allowed, continuation of the infiltration operation requires the prosecutor to submit a plan for continuation on a three months' basis.

At the moment that the empirical data on undercover policing was collected for this thesis, there were five active specialized undercover units within the Dutch police one national and four regional teams. ${ }^{15}$ Civilians may be used in undercover operations. However, in undercover buys and infiltration operations, civilians may only be used if police officers are incapable of deploying the operation. In the case of infiltration, the use of civilians who are themselves criminals was initially forbidden. ${ }^{16}$ Later on, in the aftermath of $9 / 11$, the ban on criminal civilian infiltrators was slightly loosened when the Dutch Minister of Justice deemed the use of criminal civilians permissible in terrorism investigations (Tweede Kamer, 2002-2003, 27 834, no. 28). In 2013, the ban was loosened still a bit further. In 'very exceptional cases' of organized crime, and only if police officers and non-criminal civilians cannot be used, criminal civilians may be used in an infiltration operation (Tweede Kamer, 2012-2013, 29 911, no. 83: 4).

\subsubsection{The financial approach}

From the mid-1980s onwards, organized crime control policies became supplemented with another type of approach: a finance-related strategy. Instead of 'just' investigating, arresting and prosecuting offenders, the focus shifted to attacking them financially. The financial approach basically consists of two parts: anti-money laundering measures, which aim at criminalizing the handling of 'dirty' money and preventing criminals from using the legal financial-economic infrastructure; and confiscation laws, which aim at taking away criminals' assets (Gallant, 2005: 11).

The United States played a decisive role in putting this strategy on the agenda. This dominance in setting the international agenda on the control of organized crime, similar to what we saw with regard to undercover policing, is closely linked to the exportation of the 'war on drugs' (Andreas and Nadelmann, 2006: 241-244; Beare and Woodiwiss, 2014: 545-548; Van Duyne and Levi, 2005: 19; Gelemerova, 2011; see also Paoli and Fijnaut, 2006: 325-326). Whereas the United States was a driving force behind the crime money control policies as a tool to combat drug trafficking, since the 1990s, the scope has

\footnotetext{
15 As the result of a reorganization that took place in 2008, the various undercover teams have been joined into one centrally controlled unit: the Unit Werken Onder Dekmantel (WOD), which translates as the Working Undercover Unit (see chapter 6)

16 The BOB Act itself did not specifically forbid the use of criminal civilians in infiltration operations, but such a prohibition could be inferred from the legislative debate (Beijer et al, 2004: 277-278).
} 
broadened and the financial approach has been developed into a strategy against all sorts of organized crime. In the new millennium, terrorism became the principal concern driving the expansion of the financial approach. Today, jurisdictions all over the world are familiar with anti-money laundering laws and confiscation legislation (Albanese, 2011; Hsu, 2012: 211; Kilching, 2014: 655-660; Kroeker, 2014: 272-273; Levi, 2002: 183, 186; Levi, 2012: 610; Levi, 2013: 9; Levi, 2014: 419-420; Levi and Reuter, 2009; Naylor, 2002: 247; Reuter and Truman, 2005).

\section{Anti-money laundering measures and confiscation of criminal earnings}

As stated earlier, the financial approach consists of two elements: anti-money laundering measures and the confiscation of criminal earnings.

From an offender's point of view, the aim of money laundering is to conceal the criminal origin of funds while still retaining control over them (Levi, 2014: 426). Generally, offenders participate in organized crime to gain financial (or other) benefit. Success in organized crime, however, brings its own problems for a criminal. Spending his criminal earnings carelessly might catch the attention of law enforcement authorities and could result in the offender getting arrested and losing his assets. Basically, money laundering refers to the measures an offender has to take to solve this problem. Laundering can involve various types of action. An often used but also criticized description of the laundering process identifies three sequential elements: placement of 'dirty' cash into the financial system; the layering (or structuring) of transactions to obscure the money trail by using several (foreign) accounts and shell companies, for example; and integration into the economy, which comes down to the criminal being able to consume or invest his money (Levi, 2014: 421). ${ }^{17}$

This integration, or rather 'infiltration', of criminal groups into the economy and into the licit society at large, is one of the biggest worries ever since organized crime came to be taken seriously (e.g. Barone and Masciandaro, 2011: 116; Europol, 2006; see also Verhage, 2011; Naylor, 2002: 34). The perceived threat of criminals earning and spending huge sums of money and gaining influence in economic, social and political spheres is one of the driving forces behind anti-money laundering measures (see for a review, e.g. Levi and Reuter, 2009). U.S. anti-money laundering legislation started in 1970, when the Bank Secrecy Act was introduced. The act, by establishing rules regarding record keeping, for

17 The model implies that money laundering requires all three elements. Also, by using the model, money laundering is often represented as quite complex (e.g. Schneider and Windischbauer, 2008: 394). However, investigative practice shows that laundering might also take place via rather simple methods, and without having to complete all three steps. An offender might, for example, simply smuggle his cash to a foreign country where financial supervision is poorly developed, or he keeps his money within the national borders and spends (a part of) it on an expensive car and a house registered in somebody's else's name (Akse, 2003; Kleemans et al, 2002: 108; Kruisbergen, Van de Bunt et al., 2012; Kruisbergen and Soudijn, 2015; Soudijn and Akse, 2012; PEO, 1996, Bijlage X: 135-136). 
example, required U.S. financial institutions to assist authorities in detecting and preventing criminal money flows. In the 1980s and 1990s, several other laws followed, such as the Money Laundering Control Act (1986), which established money laundering as a federal crime. Starting in the 1980 s, the financial approach to the United States' 'war on drugs' became increasingly linked with international crime control policies. The 1988 United Nations Convention against Illicit Traffic in Narcotic Drugs and Psychotropic Substances established anti-money laundering provisions. The convention emphasizes the danger of crime money enabling 'criminal organizations to penetrate, contaminate and corrupt (...) society at all its levels' (United Nations, 1988: 1). In 1989, the Financial Action Task Force (FATF) was set up, an intergovernmental body that develops and promotes anti-money laundering policies, issues 'international standards' and recommends countries to adopt measures to enable the confiscation of the profits of crime, among other things. Today, international organizations such as FATF, EU, UN, IMF and the World Bank, promote the implementation of finance-related crime control policies (see also Gelemerova, 2011).

The confiscation of criminal earnings is the second major element of the financial approach. It entails the enforcement of the ideological notion that no one should be allowed to profit from a crime; 'crime should not pay'. Furthermore, it is assumed that confiscation acts as a deterrent because it reduces its profitability and therefore the motive for crime. Confiscation is also meant to remove the financial means to participate in criminal operations and/or to 'infiltrate' in licit society. Finally, confiscated assets compensate society for the impacts of crime (Bartels, 2010: v; Lusty, 2002: 345; Naylor, 2002: 247; Nelen, 2004: 523-526). With its aggressive confiscation regime, the United States is a forerunner, but efforts to take away criminals' money are made in many countries around the world. To facilitate the confiscation of criminals' assets, legislation has been introduced, specialized organisations have been set up, and available resources have been increased (Bartels, 2010: v; Brå, 2008; Hofmeyr, 2013; Levi, 2013; Vettori, 2006: 113; Cabana, 2014: 1718; Freiberg and Fox, 2000: 239-240; Kennedy, 2007: 33-34; Kilchling 2014: 663; Lusty, 2002: 345, 351).

Although the value of recovered assets is growing, many jurisdictions are confronted with attrition, i.e. a gap between estimated criminal profits on the one hand and the actually recovered amount of money on the other. Attrition may take place during various steps of the confiscation process, e.g. regarding the number of cases in which asset recovery is applied, the court procedures, or the collection of confiscation orders. In several countries, disappointing results lay at the heart of new legislation to further enhance the possibilities for confiscation (Nelen, 2004: 520-522; Cabana, 2014: 17; Freiberg and Fox, 2000: 253; Levi, 2013: 3; Lusty, 2002: 345, 351; Van Duyne et al., 2014; Bullock et al., 2009: ii; House of Commons, 2014). 


\section{Anti-money laundering measures and confiscation of criminal earnings in the Netherlands}

In 1991, the council of the EU formulated its Directive on Money Laundering. ${ }^{18}$ This socalled 'first pillar' anti-money laundering directive obliges the member states to put effort into the fight against money laundering. ${ }^{19}$ In line with the 1991 EU directive, the Dutch legislator issued two laws in 1993: the Identification $A c t^{20}$ and the Disclosure of Unusual Transactions Act. ${ }^{21}$ The first requires clients to identify themselves before financial services are provided to them. The latter requires financial service providers to report unusual transactions to the authorities. Over the years, the sectors falling under this disclosure obligation were broadened. Furthermore, the Dutch legislator introduced a special article in the Criminal Code (article 420bis to quater) in 2001 that established the penalisation of money laundering as a crime in itself (Van der Schoot, 2006: 33-96). ${ }^{22,23}$

Although Dutch policy does not focus on specific types of crime, the anti-money laundering measures are explicitly presented as tools to target organized crime (Van der Schoot, 2006: 33-96). Just like its international counterparts, Dutch policy emphasises the dangers of large amounts of crime money entering the legal economy. Large-scale money laundering activities, according to the explanatory memorandum to the legislation penalizing money laundering, could allow organized crime groups to achieve powerful positions in the legal economy. For this reason, money laundering poses a serious threat to society (Tweede Kamer, 1999-2000, 27 159, no. 3: 5).

The possibility of depriving offenders of illegally obtained profits - which constitutes the other cornerstone of the financial approach - was introduced in Dutch general criminal

18 Council Directive 91/308/EEC of 10 June 1991 on prevention of the use of the financial system for the purpose of money laundering (Official Journal L 166 of 28.06.1991).

19 The directive focused on the laundering of proceeds of drug crimes. In 2001, a new directive was formulated (Directive 2001/97/EC). The new directive noted that fighting money laundering is an important tool to combat more types of organized crime and that the list of predicate offences should be adapted accordingly. With this new directive, therefore, money laundering applied to a broader range of crimes. Later on, a third (Directive 2005/60/EC) and a fourth directive (Directive (EU) 2015/849) followed.

20 Complete reference in Dutch: Wet van 16 december 1993 houdende nieuwe bepalingen inzake identificatie van cliënten bij financiële dienstverlening (Wet identificatie bij financiële dienstverlening), Stb. 1993, no. 704.

21 Complete reference in Dutch: Wet van 16 december 1993 betreffende melding ongebruikelijke transacties bij financiële dienstverlening (Wet melding ongebruikelijke transacties), Stb. 1993, no. 705.

22 Complete reference in Dutch: Wet van 6 december 2001 tot wijziging van het Wetboek van Strafrecht en enkele andere wetten in verband met de strafbaarstelling van het witwassen van opbrengsten van misdrijven, Stb. 2001, no. 606.

23 Money laundering became a criminal offence without the necessity of proving a specific predicate offence. Furthermore, the new article made it possible to prosecute somebody for laundering the proceeds of a crime he himself committed. Before 2001, money laundering could be prosecuted by the penalization of fencing. However, a person who committed a predicate offence could not be prosecuted for fencing with regard to the goods obtained by that offence (Van der Schoot, 2006: 33-96). 
law in $1983 .{ }^{24}$ New legislation was adopted in $1993 . .^{25}$ The new law introduced the possibility, once a defendant had been convicted, not only to claim the confiscation of the earnings resulting from the facts for which he was convicted, but to claim the confiscation of profits in relation to other crimes as well. ${ }^{26}$ In the next decades, the legislation was further amended, such as in 2003 and 2011, for example. In 2003, new legislation introduced the instrument of coercive custody of a maximum of three years in case a convict does not pay a confiscation order (after which the offender still has to pay). ${ }^{27}$ The 2011 legislation made it possible, among other things, to deploy special methods of criminal investigation such as wiretapping for the purpose of executing a confiscation order. ${ }^{28}$ Furthermore, the budget available for efforts to take away criminals' money increased in 2011 as well as in 2013 (Borgers, 2001: 270-272; Nelen, 2004: 517-520; Van Duyne et al., 2014). ${ }^{29}$

A prosecutor who wants to claim a confiscation order against a person who has been convicted of a crime has to start a separate legal procedure. At first, a district court decides on this claim, after which both the convict and the prosecution can go to the appeal court, and ultimately to the Supreme Court. ${ }^{30}$ In order to claim a confiscation order, the volume of criminal profits has to be determined by means of a financial investigation. The public prosecutor has authority over the financial investigation. The confiscation order is not the

24 It was already introduced in Dutch economic criminal law in the 1940s (Borgers, 2001: 51-67).

25 Complete reference in Dutch: Wet van 10 december 1992 tot wijziging van het Wetboek van Strafrecht en het Wetboek van Strafvordering en enkele andere wetten ter verruiming van de mogelijkheden tot toepassing van de maatregel van ontneming van wederrechtelijk verkregen voordeel en andere vermogenssancties, Stb. 1993 , no. 11 .

26 The offender's involvement in these 'other crimes' does not have to be proven to a criminal standard.

27 Complete reference in Dutch: Wet van 8 mei 2003 tot wijziging en aanvulling van een aantal bepalingen in het Wetboek van Strafrecht, het Wetboek van Strafvordering en enige andere wetten met betrekking tot de ontneming van wederrechtelijk verkregen voordeel (aanpassing ontnemingswetgeving), Stb. 2003, no. 202.

28 Complete reference in Dutch: Wet van 31 maart 2011 tot wijziging van het Wetboek van Strafrecht, het Wetboek van Strafvordering en enige andere wetten ter verbetering van de toepassing van de maatregel ter ontneming van wederrechtelijk verkregen voordeel (verruiming mogelijkheden voordeelontneming), Stb. 2011, no. 171.

29 In 2014 and 2015 new changes in the law came into force. Since 2015, the confiscation law contains a section that stipulates that judges can deduct costs directly linked to the criminal activities under consideration. This is in line with legal practice before this amendment came into force. However, as is clear from the explanatory memorandum, the amendment is intended to limit the actual deduction of costs (complete reference in Dutch: Wet van 19 november 2014 tot wijziging van het Wetboek van Strafrecht, het Wetboek van Strafvordering en de Wet op de economische delicten met het oog op het vergroten van de mogelijkheden tot opsporing, vervolging, alsmede het voorkomen van financieel-economische criminaliteit (verruiming mogelijkheden bestrijding financieeleconomische criminaliteit), Stb. 2014, no. 445; see chapter 6).

30 A case can be settled out of court when both the prosecutor and the defendant settle for an agreement on an amount of money the defendant will pay. 
only available way to recover crime money. ${ }^{31}$ However, as opposed to instruments such as fines, seizures and forfeitures, or fiscal measures, the confiscation order was introduced for the specific purpose of depriving criminals of their illegal earnings, and as such it has received the most attention in the Dutch public debate on asset recovery.

Nelen and Sabee evaluated the amended Dutch confiscation law of 1993 and found that the total sum of recovered money was way below the government's expectations (Nelen and Sabee, 1998; Nelen, 2004). In recent years, the amount of recovered money has grown considerably, especially when the results for confiscation orders, settlements out of court, and cash and other seizures and forfeitures are taken together (Openbaar Ministerie, 2014, 2015 , 2016) ${ }^{32}$ However, the confiscation process still suffers from attrition, as is clear from available data on the actual collection of confiscation orders, for example (Van Duyne et al., 2014).

\subsection{Research on counterstrategies to organized crime}

Organized crime is considered to be a threat to society. Counterstrategies to organized crime, such as the deployment of special methods of investigation or the confiscation of assets as discussed above, not only require the use of substantial amounts of public funds, they are also likely to involve a breach of fundamental human rights. These are important reasons why these counterstrategies are the subject of, sometimes heated, debate - and they should be. To provide a basis for debate and to validate underlying assumptions, organized crime policies should be a topic of empirical research. If there are no publicly available sources that provide empirical insight into organized crime and into the practice and results of counterstrategies, it is impossible to debate publicly in a rational way (Kleemans, 2014a).

When it comes to methods of investigation that are used against organized crime, empirical research is scarce. Criminal investigation is a relatively neglected field of empirical research for criminologists. One reason for this might be the simple fact that, historically, criminal investigation is just not a main point of interest within the criminological society. Another reason is the reluctance of authorities to open up to scientists and give them access to police files, for example. Scholars who do want to make an effort studying criminal investigation, therefore, often have to rely on sources such as court records, media accounts or reports of a scandal (De Poot, 2010: 102; Grabosky, 2010: 364; Marx, 1995: 329; see also Kleemans et al., 2014).

31 Other instruments are: a fine, which in some cases is used for the purpose of confiscation; the seizure and forfeiture of objects that are directly linked to a crime, e.g. when offenders involved in underground banking are arrested carrying tens of thousands of euros in cash; a transaction, stating conditions such as the payment of a sum of money, under which the right to prosecute the crime that generated the profits is cancelled (an agreement only cancels the confiscation procedure); compensation for victims; and fiscal measures (Nelen, 2004: 517-520).

32 For a significant part, the rise of the total sum of recovered money is caused by a few cases in which offenders settled out of court and paid tens of millions of euros (Openbaar Ministerie, 2014, 2015, 2016; see also chapter 6). 
Looking specifically at undercover methods of investigation, there certainly is literature on the subject. In most of the literature, undercover policing is looked upon from a critical perspective; it is often problematized as a (un)necessary evil (Ross, 2008: 240; Ross, 2007: 493; Fijnaut and Marx, 1995a: 1; Wachtel, 1992: 145). However, little empirical research has been done on undercover operations (Marx, 1988: 108-128; Brodeur, 1992: 108; Langworthy, 1989: 30; Smith et al., 2009; Giacornantonio, 2011: 453). Because of this criminological gap, very little is known about the results that undercover operations yield for criminal investigations and how regulatory procedures actually work out in investigative practice. As said, one reason concerns the fact that researchers are denied access to police files, which is perhaps even more so when a covert and deceptive method such as undercover policing is the topic of interest (Loftus and Goold, 2011: 276-277, 286). Police agencies in the Netherlands are relatively open to social science researchers. This openness is a characteristic of a progressive police force, but, in part, it is also produced as a response to the 'IRT affair'. ${ }^{33}$ Yet, in the Netherlands, too, empirical knowledge regarding methods of investigation such as undercover policing is limited. Besides the efforts of the Parliamentary Inquiry Committee on Criminal Investigation Methods (PEO, 1996, Eindrapport; Bijlage V), one empirical study has been done on undercover policing in the Netherlands (Kruissink et al., 1999). However, this research was conducted in the late 1990 s, before the introduction of the BOB Act, which significantly changed the regulation of methods of criminal investigation. ${ }^{34}$

The finance-related strategy of crime control has also been the subject of academic and political debate, but once again, the empirical research literature is very slight. There are many publications available that provide reviews of anti-money laundering policy. Yet, there is only limited empirical insight into the practice and results of policy measures (Kilching, 2014: 666; Levi, 2014: 422; Malm and Bichler, 2013; Van Duyne and Levi, 2005; Levi and Reuter, 2009: 359; Suendorf, 2001: 9; Verhage, 2011: 172; Van Duyne, 2003: 68-69; Fernández Steinko, 2012: 909; Levi, 2012). The same holds for efforts to confiscate criminal earnings. Although asset recovery as a tool to fight organized crime has received a lot of applause as well as criticism, knowledge of 'the law in action' is limited (Collins and King, 2013; Fleming, 2008: 9, 10, 21; Freiberg and Fox, 2000: 239-242; Vettori, 2006: 20). ${ }^{35}$

33 The Research and Documentation Centre (in Dutch: Wetenschappelijk Onderzoek- en Documentatiecentrum (WODC)) plays a major role in research on organized crime and criminal investigation. Because of its position as part of the Ministry of Security and Justice, researchers of the WODC have access to confidential data sources, such as police files (Kleemans, 2007; Van de Bunt, 2004: 678-679; De Poot, 2010; see also Marx, 1995: 329).

34 A number of studies have been carried out in the United States on specific types of so-called sting operations (Roberts, 2000: 272), such as on the efficacy of police anti-fencing operations (see chapter 2). However, there is almost no research that deals with the practice and results of undercover operations as an investigative instrument in general.

35 Yet, what is clear from existing literature and data is that, in several confiscation regimes, the amount of money actually collected contrasts (sharply) with the criminal profits initially estimated (see section 1.2.2). 
So although counterstrategies regarding organized crime are heavily debated, they are not often subjected to empirical research (see also Paoli, 2014: 6). As a consequence, debates and policies lack a firm empirical basis and are mainly based upon normative grounds and untested assumptions.

\subsection{Purpose and research questions of this thesis}

The aim of this study is to contribute to the empirical evidence by giving insight into the practice and results of two counterstrategies to organized crime in the Netherlands: the criminal justice approach and the financial approach.

For the criminal justice approach, we focus on a specific method of criminal investigation: the use of undercover police officers ${ }^{36}$, one of the proactive policing methods on which the police rely to investigate organized crime. As was explained before, it is also one of the most controversial methods. Furthermore, undercover operations lay at the heart of the IRT affair, which defined the course of legislative debate. In the first empirical piece of this thesis (chapter 2), data are analysed on Dutch criminal investigations in 2004, in which an undercover operation was considered. The following research questions will be addressed:

- How often are undercover operations deployed?

- What different types of undercover operations exist?

- What results have these operations produced?

The results produced by undercover operations are mainly explored by assessing the contribution an operation has made to the criminal investigation and/or trial. Such a contribution may consist of: inclusion, i.e. evidence generated by the operation that is subsequently used to get a suspect convicted; exclusion, i.e. the insight that a suspicion is probably untrue; and steering information, i.e. information that is useful for a criminal investigation in a more indirect manner, such as when the undercover operation produces information about the means of communication used by suspects. However, in addition to the contributions made by undercover operations to investigations and trials, the 'legal tenability' of these operations might also be understood as being a part of the 'results'. In order to explore how courts judge on legal issues regarding undercover operations, such as alleged entrapment, for example, Dutch case law is examined.

The answers to the stated research questions provide insight into investigative practice and results of undercover policing in the Netherlands. Furthermore, the empirical results are used to discuss the validity of some of the assumptions underlying the legislative and academic debate (which are also explored in chapter 2).

36 The use of civilians in undercover operations is not included. 
As was explained earlier, the Dutch code of criminal procedure distinguishes between three undercover police powers: systematic intelligence gathering; the purchase of illegal goods or substances or the rendering of illegal services (undercover buys); and infiltration. All of these three undercover powers are used in organized crime cases, but they may also be used to solve other types of crime. However, infiltration, the legally most serious undercover power in the Dutch code of criminal procedure, is mainly deployed in cases focusing on organized crime-related activities (or terrorism). The second set of research questions focuses on this specific type of undercover operations (chapter 3). The analysed data cover all infiltration operations in the Netherlands during the 2000-2005 period (the use of civilians in infiltration operations is not included). The legal requirements with regard to the use of infiltration are stricter than they are with regard to the other two undercover powers. In addition, a public prosecutor who wants to deploy an infiltration operation also has to comply with internal authorization procedures within the prosecution service (see section 1.2.1). One of the research questions therefore specifically looks into how regulatory procedures work out in practice.

- How often are infiltration operations deployed?

- What results have these operations produced?

- What outcomes do the regulatory requirements produce in the investigative practice?

The third and fourth sets of research questions concern the financial approach to organized crime. They focus on what organized crime offenders actually do with their money and on the efforts of law enforcement agencies to confiscate criminal earnings, respectively.

The financial approach mainly comprises of anti-money laundering policy on the one hand and confiscation or criminal forfeiture laws on the other (Gallant, 2005: 11). An important driving force behind anti-money laundering measures is the perceived threat of criminals earning and spending huge sums of money and gaining influence in the economy and in licit society at large (for a review, see e.g. Levi and Reuter, 2009; see also Barone and Masciandaro, 2011: 116; Europol, 2006; Verhage, 2009, 2011; Naylor, 2002: 34). However, there is relatively little empirical research on how offenders actually spend their money. This thesis, therefore, focuses on offenders' spending behaviour (chapter 4). The main point of interest concerns offenders' investments in legal economy, because these kinds of investments seem to be the most important reason for concern among policymakers. The empirical data consist of 150 cases from the Dutch Organized Crime Monitor. The data are used to address the following set of research questions. 
- What do offenders in organized crime invest their money in?

- Where do they invest their money?

- What can be inferred from offenders' investments about underlying strategies and motives?

The fourth and final set of research questions looks into the efforts of law enforcement agencies to confiscate criminal earnings (chapter 5). It concentrates on one specific instrument to take away an offender's money; the confiscation order. As was explained in section 1.2.2, this instrument was introduced for the specific purpose of depriving criminals of their earnings and it has received the most attention in the Dutch public debate on asset recovery.

As was explained earlier, the focus in combating organized crime has shifted from merely putting offenders in prison to taking away their money. Although the amount of recovered money is growing, many jurisdictions are confronted with the problem of attrition, i.e. the gap between estimated criminal profits on the one hand and the actually recovered assets on the other (Nelen, 2004: 520-522; Cabana, 2014: 17; Freiberg and Fox, 2000: 253; Levi, 2013: 3; Van Duyne et al., 2014; Bullock et al., 2009: ii; House of Commons, 2014). This thesis provides insight into this common but scarcely researched problem. It uses empirical data from the Dutch Organized Crime Monitor, confiscation order court files and the Central Fine Collection Agency. Together, the data sources shed light on financial investigation in practice and give a complete picture of the confiscation order court procedures as well as the execution of those orders for 102 convicted offenders; from public prosecutors' claims and rulings of the initial court, the appeal court and the Supreme Court, to what offenders actually pay. Two research questions are addressed.

- How do the investigation and confiscation of criminal profits work out in organized crime cases?

- What explanations can be offered for the phenomenon of attrition?

In the next section, the empirical data will be explained in more detail.

\subsection{Empirical data}

The first two sets of research questions, on undercover operations, are addressed, among other things, by using data on these police activities retrieved from the police and the public prosecution service. ${ }^{37}$

All the data used to address the research questions on undercover policing derive from a comprehensive research project that was conducted by the WODC (Kruisbergen and De Jong, 2010). 
Information was retrieved from the five operational specialized police undercover units with regard to all 37 Dutch $^{38}$ criminal investigations in $2004^{39}$ during which an undercover unit was consulted and in which it was decided to deploy an undercover operation. Four of the five undercover units could also produce information with regard to the investigations in 2004 during which an undercover unit was consulted, and in which an undercover operation was considered as a possible method of investigation, but where the decision was made not to deploy such an operation (46). The fifth undercover unit could not produce information on 'negative decisions'. Assuming that the ratio of positive decisions to negative decisions for these four units is also valid for the fifth unit, the total number of negative decisions comes down to 52, which brings the total number of criminal investigations in which an undercover unit was consulted for the possible deployment of an undercover operation to $(37+52=) 89 . .^{40}$

For each deployed undercover operation we interviewed the public prosecutor and/or the detective who was in charge of the criminal investigation. All these interviews, except one, took place by telephone. Furthermore, we gathered information on the undercover operations from the archives of the undercover units. Together, these sources produced insight into the sort of criminal investigations in which undercover operations are used, the length and intensity of these operations, their course and their results. Information regarding undercover operations that were not actually carried out was derived from the archives of four of the five undercover units. This information mainly concerned the reason why the operation was not executed.

The 37 (planned) undercover operations mentioned above all concerned systematic intelligence gathering and/or undercover buys; none of them concerned infiltration. To address the second set of research questions, on infiltration, we gathered information over a longer period of time, from 2000 to 2005. In general, cases in which infiltration is deployed are more complex than cases in which 'only' systematic intelligence gathering or an undercover buy is deployed; their duration is longer, they involve more suspects and/or more other methods of criminal investigation are used. ${ }^{41}$ Thus, in this research design, the data collection with regard to infiltration operations is more extensive.

38 Undercover operations within the context of international legal assistance were not included.

39 The year 2004 refers to the moment in which an undercover unit was first consulted with regard to a specific criminal investigation.

40 With regard to the four undercover units that could produce information on positive as well as negative decisions, the numbers are: 79 criminal investigations in 2004 during which they were consulted, 33 (41.8\%) times of which it was decided to deploy an undercover operation, and $46(58.2 \%)$ times of which it was decided not to deploy an undercover operation. With regard to the fifth undercover unit, it is known that in four investigations, it was decided to deploy an undercover operation. Applying the same percentages as just mentioned, the estimated number of negative decisions for this undercover unit is six.

41 However, the combination of systematic intelligence gathering and several undercover buys, for example, could result in a relatively complex operation. 
A public prosecutor who wants to deploy an infiltration operation has to submit a proposal before the CTC, as was explained in section 1.2.1. During the 2000-2005 period, such a proposal was submitted with regard to 24 Dutch criminal investigations. ${ }^{42}$ One of these cases concerned an infiltration operation that was still ongoing at the time the research was conducted. This case was excluded. For all of the remaining 23 criminal investigations, the files at the CTC were analysed, using a checklist that focused on (among other things) the grounds on which the public prosecutor wanted to deploy an infiltration operation and the decision of the CTC and the Board of Procurators General regarding the requested approval. Subsequently, for 19 of those 23 cases, we analysed the actual police files at the public prosecutor's offices. For three cases, none of which went to trial, the police files could not be traced. For one case, the public prosecutor requested the exclusion of the file. ${ }^{43}$ The police files contain the results of all police activities that were deployed in a case, such as testimonies of undercover agents and reports of wiretaps, bugging, police observations, interrogations of offenders and witnesses, financial investigation, and seizures. The files were analysed by using an extensive checklist that mainly focused on the strategy and tactics of the infiltration operation, the course and results of the operation, and the course and results of other investigative methods.

In addition, we conducted face-to-face interviews with 35 people, 20 of whom were involved in the infiltration cases we studied. The other 15 respondents were selected on grounds of their involvement in other cases in which undercover operations were used. The 35 respondents consisted of: the (former) heads of the special police undercover units (8), detectives of the National Crime Squad (6), detectives of regional crime squads (5), public prosecutors (11), staff members of the CTC (2), a procurator general (1), and other specialist members of the police (1) and Public Prosecution Service (1). Included in the interviews was the following range of topics: the kind of criminal cases and circumstances that are (not) suitable for deployment of an undercover operation; the planning, preparation and strategy of undercover operations; contacts between the undercover agent and the target; results of undercover operations; risks related to undercover operations; and the implementation of regulatory procedures.

Furthermore, we have examined Dutch case law with regard to undercover operations (systematic intelligence gathering, undercover buys and infiltration).

The third and fourth sets of research questions cover the financial approach to organized crime. The third set focuses on what organized crime offenders spend their money on, in particular their investments in the legal economy. Here the empirical data consist of a

\footnotetext{
42 Proposed infiltration operations within the context of international legal assistance were not included.

43 Information on this case was gathered by means of an interview with detectives who were involved in the investigation, and by analysing the CTC file.
} 
dataset of 1,196 individual assets of (suspected) participants in organized crime. To build this dataset, all 150 cases of the Dutch Organized Crime Monitor were analysed.

The Dutch Organized Crime Monitor is an ongoing research project that originated in the aftermath of the 'IRT affair'. A positive side effect of the Parliamentary Inquiry Committee that looked into this affair was its encouragement of empirical research on organized crime. The committee appointed an external research group, chaired by Professor Fijnaut, to make an inquiry into the nature, seriousness and scale of organized crime in the Netherlands (see Fijnaut et al., 1998). After the Fijnaut group's report was published, the Minister of Justice promised the Dutch Parliament to report periodically on the nature of organized crime in the Netherlands. To meet this need for information, the Research and Documentation Centre (in Dutch: Wetenschappelijk Onderzoek- en Documentatiecentrum (WODC)) started the Organized Crime Monitor, a systematic analysis of police investigations of criminal groups (Kleemans, 2007: 165-166). ${ }^{44}$ The main sources of information for this research project are closed Dutch criminal investigations into criminal groups. In four data sweeps, during the 1996-2011 period, 150 criminal investigations were analysed, covering a broad range of types of organized crime, such as different sorts of drug trafficking/production, human smuggling, human trafficking and illegal arms trade, but also (large-scale) fraud and money laundering. Since each case focuses on a criminal network, together, the 150 case reports contain information on many hundreds of suspects.

The selection of case studies takes place following a survey of criminal investigations of the police force and special investigative policing units. The selection is not random. In fact, a random sample is inconceivable in organized crime research, because police priorities - highlighting certain criminal activities and certain suspects - provide the basis for any sample researchers should want to construct. The researchers therefore opt for a strategic sample that incorporates the heterogeneity of criminal activities and offenders (for more information, see: Kleemans, 2007). When selecting cases, richness of information is an important selection criterion. Furthermore, efforts are made to avoid focusing solely on, for example, drug trafficking. Some types of organized crime are 'oversampled' on purpose, as they add more knowledge to what we already know (Van Koppen, 2013b: 11). Each case study starts with an interview with a police officer and/or public prosecutor. Subsequently, using an extensive checklist, the police files are analysed and a case report is written. The checklist elaborates upon: the composition of the group and how offenders cooperate; the illegal activities they participate in and the modus operandi used; the interaction with the licit as well as the criminal environment; the criminal earnings and how these earnings are spent; the criminal investigation itself; the criminal court case; and opportunities for prevention

44 Major reports to Parliament were published in 1998, 2002, 2007 and 2012 (Kleemans et al., 1998, 2002; Van de Bunt et al., 2007; Kruisbergen, Van de Bunt et al., 2012). 
(Van Koppen et al., 2010: 108; Kleemans and De Poot, 2008: 70; for more information, see: Kruisbergen, Van de Bunt et al., 2012; Kleemans, 2007).

To answer the third set of research questions, all 150 case reports were checked for available information on offenders' assets. This resulted in a database of 1,196 individual assets, which were entered in SPSS. When checking the case reports, every source of information available was used, i.e. not only confiscated assets were taken into account but also statements of suspects and witnesses, intelligence from informers, seized bookkeeping and records, and monitored telephone conversations, among other sources. As said, the focus is on investments in the legal economy, such as real estate objects, companies, bonds and options, leaving aside investments in criminal activity as well as any form of consumption, such as money spent on nightlife and cars. Cash money and deposits are also excluded from our analyses. For the purpose of this thesis, keeping money in cash is not considered as an 'investment'. ${ }^{45}$

The fourth and final set of research questions focuses on financial investigation and confiscation orders applied in organized crime cases. Three sources of empirical data were used. The first source consists of cases from the Dutch Organized Crime Monitor. At the moment a case is studied for this monitor, the court procedures are often not completed, let alone the execution of measures such as confiscation orders. Therefore, a second data source was used; the Central Fine Collection Agency (CJIB), responsible for the execution of sanctions such as fines and confiscation orders. From the 120 cases of the first 3 data sweeps of the Dutch Organized Crime Monitor, we retrieved the names as well as date and place of birth of more than 1,600 suspects. ${ }^{46}$ This dataset was sent to the CJIB to be matched with their confiscation database. The matching procedure produced 119 convicts for whom it could be established that their involvement in one of the cases resulted not only in a criminal conviction but also in a confiscation order. The CJIB sent back a database with information on the actual collection of those 119 confiscation orders. The third data source consists of court files. These were analysed to retrieve information on court procedures preceding the final confiscation order, the grounds on which a court decided whether or not to diverge from the prosecutor's claim (and/or from the decision of lower courts), and the facts and assumptions used to estimate the criminal profit. For 102 convicts information was found on all phases of the court system; the district court, the appeal court and the Supreme Court (not all cases went to higher courts). The information on these 102

45 Furthermore, if cash money and deposits would be included in the analyses, consequently, some 'investments' would be entered twice in the dataset. This would be the case if, for example, information in a case report indicates that an offender has smuggled cash to a foreign country to buy a house. In such a case the house is entered in the dataset as a real estate object; also entering the cash would produce a double entry.

46 Because court procedures as well as the execution of confiscation orders can take a long time, the fourth data sweep was not included. 
confiscation cases was entered into SPSS. Seventeen convicts for whom the information was not complete were excluded from the database. These combined three data sources give insight into the financial investigations in organized crime cases and give a complete picture of the confiscation order court procedures as well as the execution of those orders for 102 convicted offenders; from public prosecutors' claims and rulings of the initial court, the appeal court and the Supreme Court, to what offenders actually pay. The strengths and weaknesses of the methods and data used will be elaborated upon in chapter 6 .

\subsection{Outline of this thesis}

In chapter 2, all the undercover operations deployed in the Netherlands in 2004 are analysed. Furthermore, the academic and legislative debate on this policing method are discussed. Chapter 3 focuses on the regulation, practice and results of the legally most severe undercover power in the Netherlands, infiltration. All the infiltration operations during the 2000-2005 period are analysed. Chapters 4 and 5 address the financial approach to organized crime. Chapter 4 looks into the investments of organized crime offenders in the legal economy. This chapter holds the outcomes of analyses of a database of 1,196 assets of offenders. Chapter 5 focuses on the practice and results of financial investigation and confiscation in organized crime cases. For 102 convicted offenders, it gives a complete picture of the confiscation order court procedures as well as the execution of those orders. The final chapter (6) provides a summary of the results of the previous chapters, as well as an integration of those results and a discussion of the possible implications with regard to counterstrategies to organized crime. Furthermore, the methodological strengths and weaknesses of this thesis are discussed and some suggestions are made for further research.

Chapters 2, 3, 4 and 5 were previously published as articles in journals. As a consequence, certain information, on the history and regulation of undercover operations, for example, may be found in more than one chapter. 


\section{Undercover policing: assumptions and empirical evidence}

This chapter describes and analyses the implementation and results of undercover operations in one country (the Netherlands). ${ }^{47}$ First, we discuss assumptions underlying academic and legislative discourses relating both to the regulation and control of undercover operations and to the kind of results the operations may produce. Second, we analyse documentation and interviews relating to all 89 Dutch criminal investigations in 2004 in which undercover teams were consulted.

\subsection{Introduction}

Recent years have seen a shift from reactive to proactive policing (Roberts, 2007: 99; Maguire and John, 1996: 316-18). This shift, caused by the rise of organized crime and concerns about terrorism, has been accompanied by the use of increasingly invasive investigative techniques. ${ }^{48}$ Examples are covert yet non-deceptive techniques such as telephone tapping and electronic surveillance, but also deceptive techniques such as undercover policing. Compared to other methods of criminal investigation, undercover operations are different not only because of their covert and deceptive nature, but also because the police participate in the very crimes they are investigating (Ross, 2008: 239).

In many countries, the use of covert policing has been the subject of heated debate, sometimes as a result of outright (political) scandals (see section 2.3; see also Ross, 2008: 240). The debates usually imply that undercover policing is a controversial investigative method: a necessary or unnecessary 'evil'. Commonly, however, these debates lack basic empirical evidence and are mainly based upon normative grounds and untested assumptions.

This chapter describes and analyses the implementation and results of undercover operations in one country (the Netherlands). First, we discuss assumptions underlying academic and legislative discourses relating both to the regulation and control of undercover operations and to the kind of results the operations may produce. Second, we analyse

\footnotetext{
47 A slightly different version of this chapter was earlier published as: Kruisbergen, E.W., De Jong, D. and Kleemans, E.R. (2011). Undercover Policing: Assumptions and Empirical Evidence. British Journal of Criminology, 51(1): 394-412.

48 In section 2.2, we elaborate upon the growing importance of proactive policing.
} 
documentation and interviews relating to all 89 Dutch criminal investigations in 2004 in which undercover teams were consulted. ${ }^{49}$

We will address the following research questions: How often are undercover operations deployed? What different types of undercover operations exist? and What results have these operations produced? The empirical data consist of all undercover police operations in the Netherlands in 2004 and the available Dutch case law (over several years) regarding undercover operations. For a further discussion of these data sources, we refer to section 2.4.

In addressing these research questions, we briefly examine the history of undercover operations in Europe and the United States (section 2.2) and look into the academic and legislative debate regarding undercover operations (section 2.3). Furthermore, we introduce our empirical data (section 2.4), present empirical insight into the numbers, types, course and results of undercover operations in the Netherlands (section 2.5), and examine the Dutch courts' judgments regarding the legitimacy of undercover operations (section 2.6). Finally, we summarize the results and discuss the validity of the assumptions underlying the academic and legislative debate (section 2.7).

\subsection{Undercover operations: a brief history}

The use of spies and informants to gather information on rivals and subjects was described by the Romans (Gibbon, 1831). However, the systematic use of undercover policing became possible only with the emergence of more or less modern police organizations (Marx, 1988: 17). Such a police organization first came into being in Paris at the end of the seventeenth century. Its goal was to protect the political order of the city, yet it also targeted criminal matters. The notorious bureau de surêté deployed undercover operations on a large scale (Fijnaut and Marx, 1995a: 2-3). During the eighteenth century, the United Kingdom became acquainted with the thief takers: citizens who were part of the underworld and who recovered stolen property for a reward. Undercover methods were also used by what is often called London's first professional police force, the Bow Street Runners, set up in the mid eighteenth century by Henry Fielding. Modernization of the police system took place with the passage of the Metropolitan Police Improvement Act, in 1829. The traditional system of parish policing was replaced by the new police (Fijnaut and Marx, 1995a: 7-8; Goddard, 1957). To contrast the new police with the broadly feared continental, 'tyrannical' type of policing, Home Secretary Sir Robert Peel presented the model of

49 We retrieved information from the five specialized undercover units with regard to all 37 criminal investigations in 2004 during which an undercover unit was consulted and in which it was decided to deploy an undercover operation. Four of the five undercover units could also produce information with regard to 46 investigations in which the consultation ended in a decision not to deploy an undercover operation. Assuming that the ratio of positive decisions to negative decisions for these four units is also valid for the fifth unit, the total number of negative decisions comes down to 52 , which brings the total number of criminal investigations in which an undercover unit was consulted to $(37+52=) 89$ (see chapter 1$)$. 
policing by consent. It expressed the philosophy of preventive policing via a uniformed presence rather than a secret police presence (Roberts, 2007: 97; Fijnaut and Marx, 1995a: 7-9). However, because the system was not effective enough, in 1842, a team of plainclothes detectives was formed. Threats to the political order during the last decades of the nineteenth century, such as the Fenian bombings, led to an expansion and specialisation of active forms of undercover policing (John and Maguire, 2007: 200; Fijnaut and Marx, 1995a: 8-9).

The United States shared the British fear of a continental police system and its associated informants and spies - a fear that was enhanced by its struggle for independence. It lacked federal investigation services of any size until the beginning of the twentieth century, when the Federal Bureau of Investigation (FBI) was formed. During the 1920s and 1930s, the FBI used undercover operations in the fight against espionage and sabotage committed by communist and fascist groups (Fijnaut and Marx, 1995a: 10-14).

During roughly the same period, the political use of undercover policing steeply increased in Europe as well. Yet, in post-war Europe, undercover methods were initially discredited, as a result of the intensive use the national-socialist Third Reich and the communist Soviet Union had been making of government espionage against their own populations (Marx, 1988: 22-32).

An increase in the use of undercover operations by the regular police (outside the sphere of state security) has occurred from the 1960s onwards, during a period when organized crime, primarily centred on drug trafficking, has been growing. Because of the consensual nature of these crimes, reactive investigative methods are less adequate. Reactive policing, primarily instigated by victim reports and criminal events and focused on gathering evidence on past behaviour of offenders, is therefore increasingly replaced by proactive policing, which aims at gathering evidence on the current and future behaviour of offenders. In the United States, this has resulted in the large-scale use of undercover operations, mainly in the form of so-called buy-bust operations. These are operations in which the police create the opportunity for someone to commit a crime, such as by having an undercover agent pose as someone who wants to buy drugs. As part of its war on drugs, the American Drugs Enforcement Administration (DEA) exported the use of this investigative instrument to Western Europe. Because of the 'importation' of these operations, the use of undercover methods by the police has increased in Europe as well (Ross, 2008: 241; Fijnaut and Marx, 1995a: 15-16).

The use of undercover operations is not limited to investigations into drug crimes. In the United States, so-called anti-fencing sting operations are directed against property crimes (Marx, 1988: 108-128). More recently, sting operations are brought into action on the Internet, too, with American undercover agents posing as juveniles in order to catch online sex offenders (Mitchell et al., 2005: 251-256). Undercover operations against drug trading, just as those against fencing and online sex offenders, are usually proactive. Yet, 
undercover operations are also applied in reactive criminal investigations. They have been used to elicit confessions from suspects in investigations regarding, among other crimes, murder and missing people (e.g. Maguire and John, 1996: 316-318; Choo and Mellors, 1995; see also Smith et al., 2009). In these 'befriending' operations, an undercover agent befriends a suspect and tries to build up such a relationship with him (or her) that the suspect confides his guilt to his 'friend'. ${ }^{50}$

\subsection{Academic and legislative debate: theory and assumptions}

\subsubsection{Academic debate}

In the literature on this subject, Gary T. Marx's (1988) Undercover: Police Surveillance in America is still the standard work. In his exploratory study, Marx examines the different manifestations of undercover operations, the developments in their use, and their intended and unintended consequences. The author mostly uses interviews, literature and documents. The full scope of Marx's treatment of the subject is unique. Often, other authors only discuss a partial aspect of this investigative instrument.

Many studies focus on the deception or manipulation to which citizens caught up in undercover operations are assumed to be exposed. These studies often pursue the issue of entrapment in buy-bust and sting operations (Ross, 2008: 242). The central question regarding entrapment is whether such operations actually tackle real criminals, or whether the police incite individuals to committing a crime who did not have any criminal intent to begin with (e.g. Ashworth, 2002; Colquitt, 2004).

While deception in a buy-bust operation takes place for the purpose of catching a person red-handed, in another type of operation, people are deceived in order to get them to confess to crimes already committed. This is the case in the aforementioned befriending operations. According to some, during those operations, the safeguards applying to the interrogation of a suspect are skirted.

Several authors have focused on the risks that may be involved in undercover operations for undercover agents. Such risks involve, among others, a compromised integrity (Girodo 1991) and psychological problems (e.g. Miller, 2006; Macleod, 1995). Ross (2004; 2007) and Fijnaut and Marx (1995b) have approached the subject from the point of view of the sociology of law; they describe the international differences in the field of undercover policing.

Many studies discuss the lack of control over undercover policing, in light of secrecy, deception and risks attached to the instrument (e.g. Den Boer, 1997; Wagner, 2007). A

\footnotetext{
50 A notorious British example is the befriending operation that was deployed in the Rachel Nickell murder investigation in 1992.
} 
number of authors advocate a more strict regulation (e.g. Joh, 2009: 195-196; Roberts, 2000: 273; Maguire and John, 1996: 320-321, 332-334; Choo and Mellors, 1995).

An important part of the scientific literature looks upon undercover operations from a normative, critical point of view (Ross, 2008: 240). These studies frequently problematize undercover operations as a necessary evil (Fijnaut and Marx, 1995a: 1; Wachtel, 1992: 145; Ross, 2007: 493). They often chiefly examine the assumed negative aspects of undercover methods, paying less attention to the possible value of this means to criminal investigations, thus making undercover operations seem more of an unnecessary evil. Yet, what do we actually know about the practice of the execution of undercover operations and about the results they yield for criminal investigations? Not much. Little empirical research has been done on undercover operations (Marx, 1988: 108-128; Brodeur, 1992: 108; Langworthy, 1989: 30; Smith et al., 2009; see also Grabosky, 2010: 364), though some research has been done in the United States (Roberts, 2000: 272). A number of very specific studies have been carried out, such as on the efficacy of police anti-fencing operations (e.g. Bowers and McCullough, 1982; see also Langworthy, 1989). These studies primarily focused on the output of these operations, namely the number of arrests and convictions and the amount of recovered property. Such studies also provided the foundation on which Marx based his discussion of the 'intended consequences of undercover work' (Marx, 1988: 108-128). More recently, Webster et al. (2006: 228-229) have carried out a study on stings in the United States, the aim of which was to prevent the spread of firearms from the legal arms trade into the underworld. Furthermore, Mitchell et al. (2005: 251256) have studied undercover operations in which American undercover agents posed as minors in chat sessions on the Internet, in order to trace potential sex offenders (see also Fulda, 2002). Thus, some studies provide information on the results of specific types of sting operations. Yet, almost no research exists that deals with the practice and results of undercover operations as an investigative instrument in general. ${ }^{51}$

\subsubsection{Legislative debate}

Legislation and guidelines regarding police powers are the most formal and direct means used to control police activities. Incidents and specific criminal cases play a key role in the development of regulation concerning police powers. In the United Kingdom, for example, the ideology of policing by consent was accompanied by a common law tradition of implicit police powers, namely police activity required no explicit legal authorization. Although this tradition still stands, policing methods are increasingly subjected to formal statutory regulation (Roberts, 2007: 97). The judgment of the European Court of Human Rights in Malone v. United Kingdom (1985) led to the Interception of Communications Act 1985. Another case that played a significant role in the regulation of police powers is the

51 Such research has been done once in the Netherlands (Kruissink et al., 1999). 
case of Khan. ${ }^{52}$ In this case, the police mounted monitoring equipment to the outside wall of a house. The House of Lords criticized the lack of any legislation for such an invasive investigative method. Khan was one of the motivating factors behind the Police Act 1997. The most important statute today is the Regulation of Investigatory Powers Act (RIPA) 2000, which also regulates covert policing methods.

In the United States, the Abdul Scam (ABSCAM), which ran in the late 1970s, led to a controversy. In this operation, undercover agents, dressed as rich Arabs, approached members of Congress and offered them money in return for political favours. ABSCAM resulted in several convictions, but the use of this technique was criticized as well. In the aftermath of this operation, the Department of Justice issued The Attorney General Guidelines for FBI Undercover Operations (Gershman, 1982: 1585-1586).

In continental European jurisdictions, the exercise of police powers requires a formal basis in the national police law or code of criminal procedure (Roberts, 2007: 96). However, until 2000, the Dutch code of criminal procedure lacked specific sections that covered intrusive investigative techniques such as undercover policing and surveillance. This legal vacuum was at the basis of the IRT affair, which defined the course of the Dutch legislative debate. In response to growing concerns about organized crime in the 1990s, interregional investigation squads (IRTs) were established. The sudden dismantling of the AmsterdamUtrecht IRT in 1993 and internal disputes within the police resulted in a parliamentary inquiry committee. The IRTs had deployed new investigative methods and the committee concluded that some of them were unacceptable. Several tons of drugs had been imported under the supervision of the police, in the hope that particular informers would move to the top of criminal organizations. It was questioned, however, whether the authorities were running the informers or vice versa. Furthermore, the committee made a thorough inquiry into several criminal investigation methods, including undercover operations. Some of the major conclusions were that there was a legal vacuum concerning criminal investigation methods and that the command and control of criminal investigations should be improved. The report of the committee (PEO, 1996, Eindrapport) led to the Act on Special Investigative Police Powers (in Dutch: Wet bijzondere opsporingsbevoegdheden (BOB Act)). The BOB Act, effective as from 2000, regulated several investigative powers, enhanced central authority in criminal investigations, and required accountability at trial for the deployment of the investigative powers (Kleemans, 2007: 164-165).

In regulating undercover operations, Parliament opted for a threefold division in powers in the BOB Act: systematic intelligence gathering; the purchase of illegal goods or substances or the rendering of illegal services (undercover buys); and infiltration. The deployment of infiltration is assumed to be more risky than the deployment of an undercover buy, which, in turn, is assumed to be more risky than systematic intelligence gathering. The

52 R. v. Khan (1996) 3 All ER 289. 
underlying idea is that during systematic intelligence gathering, the undercover agent 'just' collects information; he is not committing any crimes, as he would be when purchasing illegal goods or substances, nor is he taking part in any criminal organization, as is the case with infiltration. The requirements for the deployment of the undercover powers differ correspondingly. Infiltration is only allowed in investigations that target the most severe crimes (proportionality), whereby other investigative methods are ineffective (subsidiarity), and only after authorisation from the highest level within the Public Prosecution Service (the Council of Procurators General). By contrast, the other two undercover powers (undercover buys and systematic intelligence gathering) may be deployed against a (much) broader category of crimes, without an exhaustive exploration of alternative methods of investigation, and without authorisation of the Council of Procurators General.

\subsubsection{Assumptions in academic and legislative debate}

In this chapter, we focus upon three assumptions from academic and legislative debate. The first assumption relates to the control of the course that undercover operations will take. An important underlying idea, or fear, is that the police, through deception, exert a manipulative influence on citizens while executing undercover operations. The assumption seems to be that the actual execution of an undercover operation, namely the interaction between undercover agent and subject, is completely determined by the undercover agent: 'the undercover agent leads the subject into a trap.' Thus, in the contact between both actors, a mainly active, directive role is attributed to the agent, while a more passively following part is attributed to the subject.

Second, in the existing literature, the results of undercover operations are discussed almost exclusively in terms of arrests, seizures and convictions. ${ }^{53}$ Almost no attention is paid to other possible yields. These are, for instance, the possible insight an undercover operation may provide into the composition and mode of operation of a criminal organization, or the evidence that someone has been under suspicion by mistake. The assumption entertained here is that undercover operations can only lead to proving someone's guilt. Hence, criminal investigation seems to be represented as a linear process, leading from suspicion to conviction.

The third assumption is the legislator's supposition that undercover operations can be clearly distinguished - such as in the Dutch BOB Act - into three different types of operations, and that growing risks are attached to them.

After presenting our empirical results in the next sections, we will confront our results with these three assumptions in the final section and discuss their validity.

53 Sometimes, the possibly deterrent, preventive effect of undercover operations is discussed as well. 


\subsection{Current Study}

The empirical data we use in this chapter consist of two sources. In the Netherlands, most undercover operations are carried out by specialized undercover units. ${ }^{54}$ When a public prosecutor, who, under Dutch law, has the authority over a criminal investigation, considers the use of an undercover operation, he usually contacts the undercover unit. Our first data source covers all 89 Dutch criminal investigations in 2004 in which these specialized teams were consulted. ${ }^{55}$ This data source is unique, since information on undercover operations is generally not available to researchers, let alone to the broader public. ${ }^{56}$ For every undercover operation that was actually deployed (see Figure 1), we gathered information from the archives of the undercover unit and we interviewed the public prosecutor and/or the detective who was in charge of the criminal investigation. This produced insight into the sort of criminal investigations in which undercover operations are used, the length and intensity of these operations, their course and their results. ${ }^{57}$ Information regarding undercover operations that were considered but not actually carried out was also derived from the archives of the undercover units. This information mainly concerned the reason why the operation was not deployed.

The second data source consists of documents relating to judicial reasoning regarding the legitimacy of undercover operations. In the Netherlands, judicial sentences are stored in a public database. ${ }^{58}$ In total, we have looked at the relevant documentary evidence relating to judicial reasoning in more than 60 cases that involved an undercover operation and in which a judge has passed judgment on the legitimacy of covert policing as an investigative instrument. $^{59}$

${ }^{54}$ At least when the research was conducted (see also section 6.2.1 in chapter 6).

55 We retrieved information from the five specialized undercover units with regard to all 37 criminal investigations in 2004 during which an undercover unit was consulted and in which it was decided to deploy an undercover operation. Four of the five undercover units could also produce information with regard to 46 investigations in which the consultation ended in a decision not to deploy an undercover operation. Assuming that the ratio of positive decisions to negative decisions for these four units is also valid for the fifth unit, the total number of negative decisions comes down to 52 , which brings the total number of criminal investigations in which an undercover unit was consulted to $(37+52=) 89$ (see chapter 1$)$.

56 As mentioned before, the Dutch law distinguishes between three kinds of undercover powers. In 2004, all undercover operations consisted of the undercover powers of systematic intelligence gathering and/or undercover buys. In 2004, infiltration was not used. For cases in which infiltration was used, we gathered information over a longer period of time, from 2000 to 2005. During those six years, infiltration was deployed in 14 cases. In this chapter, we only use the 2004 data.

57 In order to guarantee anonymity, examples of undercover operations that we present in this chapter are generalized and lack concrete details.

58 Only a very small part of all sentences is entered into the database. We searched this database for the period 2000-August 2007 and expanded our results with rulings before and after this period that were brought to our attention by members of the Public Prosecution Service or the literature.

59 For more elaborate information on the data, see chapter 1 (see also Kruisbergen and De Jong, 2010). 


\subsection{Undercover operations in the Netherlands: numbers, types, course and results}

\subsubsection{Numbers}

The archives of the undercover units show that, in 2004, the deployment of an undercover operation was considered in 89 criminal investigations (see Figure 1) ${ }^{60}$ In 52 cases, it was eventually decided that the use of this method was not possible or unnecessary. One reason was the lack of sufficient information on the suspect and his entourage, which made it impracticable to come up with an adequate approach plan. Another reason was the presence of factors that impeded the safe deployment of an undercover operation, such as a mentally unstable and therefore unpredictable suspect. In other cases, an undercover operation turned out to have become unnecessary because the aims of the investigation had already been attained by other means, such as through an unexpected tip-off from the underworld.

Thus, in 37 cases, it was decided to set up an undercover operation. In three of these cases, however, the operation was abandoned even before the start. This happened, for example, in an investigation into firearms trafficking. In this investigation, observations and telephone taps made clear where the weapons were stored, which resulted in the arrest of the suspect and seizure of the firearms. Ultimately, 34 undercover operations have actually been carried out. We may conclude that undercover operations are not used very often in the Netherlands. This becomes even more clear when we compare it to the use of telephone taps: in 2008, 26,425 Dutch telephone numbers have been tapped (Tweede Kamer, 2008-2009, 30 517, no. 13).

\subsubsection{Types}

In criminal investigation, we discern three types of undercover operation, which largely correspond with the three different undercover powers distinguished by Dutch legislation. The first category of undercover operations consists of cases involving systematic intelligence gathering: an undercover agent tries to gather information on the involvement of a suspect in, for instance, a seriously violent crime or sexual exploitation. An example of this is a case in which an undercover agent tried to find out, by befriending the suspect, whether the suspicion was correct that a man has been involved in a murder. The second category of operations usually focuses on the trading of stolen property, drugs or weapons.

60 We retrieved information from the five specialized undercover units with regard to all 37 criminal investigations in 2004 during which an undercover unit was consulted and in which it was decided to deploy an undercover operation. Four of the five undercover units could also produce information with regard to 46 investigations in which the consultation ended in a decision not to deploy an undercover operation. Assuming that the ratio of positive decisions to negative decisions for these four units is also valid for the fifth unit, the total number of negative decisions comes down to 52 , which brings the total number of criminal investigations in which an undercover unit was consulted to $(37+52=) 89$ (see chapter 1). 
During these undercover buys, the idea is that the undercover agent purchases such goods from a suspect to obtain direct proof that the suspect is indeed involved in these crimes. Several times, the cause for these cases has been that the police got notified of illegal or stolen goods being on offer on the Internet. During the ensuing operation, an undercover agent then responded to the offer and tried to buy the goods concerned.

In the third category of operations, undercover buys are part of the undercover operation as well. The difference with the second category is that the undercover operation does not target individual suspects, but criminal organizations and, to a large extent, the large-scale drug or firearms trade. Furthermore, apart from the gathering of direct evidence, the aim of these operations is to gain insight into the composition and mode of operation of the criminal organization. These operations may involve infiltration or an combination of systematic intelligence gathering and (an) undercover buy(s).

The different types of operation vary greatly with regard to their duration, intensity and the sort of contact between the undercover agent and the subject. Some undercover operations only take a day and consist of no more than a brief business contact with a suspect. One example is a case in which the police intercepted a drugs parcel sent by post; an undercover agent then posed as the postman delivering the parcel in order to arrest the recipient. An undercover operation may also last more than a year, however, and may encompass many meetings between undercover agent and suspect. In general, the application of systematic intelligence gathering and infiltration requires a longer period of time and more intensity than when a single undercover buy is applied.

Between the different types of operation, the nature of the contacts varies as well. The contacts may be purely businesslike, such as in many investigations targeting drugs or weapons (undercover buys and infiltration). Yet, in cases in which an undercover agent befriends a suspect in order to get information about his involvement in a seriously violent crime (systematic intelligence gathering), as in the murder case mentioned above, the undercover agent sometimes has to establish a quite intensive personal and emotional bond with the suspect. It is clear that this requires a very different 'investment' on the part of the undercover agent.

\subsubsection{Measuring success and failure}

What defines a successful undercover operation? Particularly with regard to operations that are not directed at specific suspects, but rather focus on a category of persons - so-called fishing expeditions or honey pot operations - it can be hard to determine indicators of success. Examples of these unfocused operations are the aforementioned anti-fencing stings in the United States. Yet, honey pots are also used to detect crimes such as corruption among politicians and civil servants. How many thieves must be caught or how many stolen goods must be seized during such an operation for it to be ranked as a success? And when a politician does not take the 'bait' of a corrupting offer posed to him by an undercover 
Figure 1 Implementation and results of undercover operations in the Netherlands, 2004.

\section{Deployment of undercover operation is considered: $\mathbf{8 9}$}

\begin{tabular}{|c|c|}
\hline $\begin{array}{l}\text { Decision to deploy } \\
\text { undercover operation: } \mathbf{3 7}\end{array}$ & $\begin{array}{l}\text { Decision not to deploy } \\
\text { undercover operation: } \mathbf{5 2}\end{array}$ \\
\hline $\begin{array}{l}\text { Undercover operation is } \\
\text { implemented: } 34\end{array}$ & $\begin{array}{l}\text { Undercover operation is } \\
\text { not implemented: } 3\end{array}$ \\
\hline $\begin{array}{l}\text { Undercover agent makes } \\
\text { contact with target: } \mathbf{3 1}\end{array}$ & $\begin{array}{l}\text { Undercover agent makes } \\
\text { no contact with target: } 3\end{array}$ \\
\hline $\begin{array}{l}\text { Undercover operation delivers } \\
\text { contribution to investigation } \\
\text { and/or trial: } 12 \\
\text { - evidence used for conviction of } \\
\text { suspect (inclusion): } 7 \\
\text { - exclusion suspect: } 4 \\
\text { - steering information: } 1\end{array}$ & $\begin{array}{l}\text { Undercover operation delivers no } \\
\text { contribution to investigation and/or } \\
\text { trial: } 22\end{array}$ \\
\hline
\end{tabular}

agent, does this mean that the operation has failed or that the official has been deterred by earlier undercover operations, or that he never intended to commit a crime in the first place (Marx, 1988: 108-109)?

All Dutch undercover operations we studied were focused; specific targets (suspects) were identified in advance. According to Marx (1988: 108-109), the assessment of success for these kinds of operations is much simpler. And, indeed, when a sting operation is targeted at a single suspected drug trafficker, for example, and the suspect sells drugs to an undercover agent, resulting in the arrest of the suspect, assessing the success of the operation might seem straightforward.

However, not all targeted undercover operations are that simple, and even in the given example, one might argue about what indicates its success. Should we take the direct result 
into consideration, namely the successful undercover buy and possibly an arrest, or is the eventual conviction the only result that matters? And does it suffice solely to measure the success of an undercover operation by arrests and convictions?

In our study, we determined the success of an undercover operation by assessing the contribution an operation has made to the investigation and/or trial. To this end, we make a distinction between three kinds of contribution. The first of these is inclusion, which means that the undercover operation has generated evidence that is subsequently used to get a suspect convicted. In the literature on undercover operations, the presented indicators of success of an operation often only consist of convictions, arrests and seizures. However, undercover operations can produce other types of results as well. They can, for instance, yield the insight that a suspicion is probably untrue. A second kind of contribution is, therefore, exclusion. Third, there are operations that neither directly result in convictions nor lead to exclusion, but that do yield information that is useful for a criminal investigation in a more indirect manner. An example of this is information about the means of communication or the smuggling methods used by suspects. We call this kind of contribution steering information.

Figure 1 shows the implementation and results of Dutch undercover operations in 2004. An undercover operation was set up in 34 cases. What were the results of these operations? In 12 cases, the undercover operation has contributed to the investigation and/ or trial. This means that the undercover operations did not make any contribution in the remaining 22 cases.

In seven cases, the operation yielded evidence that was used to convict the suspect(s). One example was an undercover operation set up when stolen goods worth hundreds of thousands of Euros were put on offer in bulk on the Internet. An undercover agent succeeded in buying these goods. This undercover buy was then used to convict the suspect and also led, through the apprehension of the receiver, to the arrest of the thief. Another example is a protracted undercover operation targeting illegal arms trade. The undercover agent managed to identify the suspect who, until then, had been unknown. He built up a contact with this man successfully and eventually bought a consignment of weapons from him. This undercover buy, too, played an important part in the suspect's conviction.

In four cases, a suspect could be excluded from the investigation based on the results of the undercover operation. Exclusion is a valuable result, because it enables the investigators to focus on other suspects or to abandon the investigation altogether. In one of these four cases, an undercover agent was put into action against a person suspected of being involved in a murder. The undercover agent befriended the suspect and gained his trust - the suspect stated in an intercepted telephone call that the undercover agent was one of only two persons he could trust. This strong bond and the candour with which the suspect confided in his 'friend' enabled the investigation team at one point to conclude that their suspicions against this man were probably incorrect. In another case, an investigation 
was started as a result of information that at a certain 'location', drugs were being traded and girls were being sexually exploited. After visits of an undercover agent to this location, it became clear that the initial information was not correct.

In one case, the undercover operation did not lead to evidence or exclusion, but 'only' generated steering information. In this investigation, the undercover operation provided a picture of the composition of the criminal organization, and of the means of transportation this organization used for its drug trafficking. A planned undercover buy, however, could not be effected.

Twenty-two of the 34 executed undercover operations have ended without generating results. In three of these cases, the investigators failed to come into contact with the target. In one such case, the team initially deemed the possibilities to make contact with the target to be favourable. Yet, suddenly, the catering establishments in which these contacts were planned to take place were no longer frequented by the target, among other reasons because he (the target) was refused admittance. In 19 cases, the undercover agent did actually succeed in establishing contact with the (initial) target, yet, in the end, the operations still failed to contribute to the investigation or trial concerned. There are various backgrounds to these failures. Sometimes, the undercover agent's assignment is to make contact, through the initial target, with the person who is the actual subject of the investigation, the main suspect. This plan can fall through because the assumed relation between the initial target and the actual subject no longer exists or has never existed. In the majority of the unsuccessful cases, however, contact between the undercover agent and the subject of the investigation has been established, but the meetings and conversations held and the observations made by the undercover agent failed to generate the decisive information needed to either confirm or negate a suspicion. In one investigation into terrorism, an undercover agent maintained fairly good relations with the suspect concerned, but the suspect did not talk about relevant topics during their meetings. Operations involving undercover buys also regularly fail to yield results.

\subsubsection{The unpredictable criminal environment}

The most remarkable characteristic of undercover operations we have studied is the unpredictability of how the meetings between the undercover agent and the suspect, and thus the entire operation, will work out. We have already mentioned the case in which an undercover agent could not establish contact with a suspect because the latter unexpectedly failed to show up in the establishments where the contact was meant to take place. Yet, unpredictability manifests itself most strongly during the phase in which contact has already been established and mainly during operations involving undercover buys, such as in many investigations into the drug trade, the illegal arms trade or the traffic in stolen goods. The unpredictability of those operations is caused to a large extent by the dangers of criminal entrepreneurship. 
In undercover operations set up to combat profit-motivated crime, such as the drug trade, an undercover agent, in order to gather evidence against a suspect, often poses as a criminal entrepreneur. He uses the cover of a drug dealer, for instance, who is interested in buying drugs. Because the undercover agent plays the role of fellow criminal, operating on the criminal market, the risks involved in criminal entrepreneurship apply to him, too - a hazard that also looms over the success of the undercover operation.

There are three types of risk attached to criminal entrepreneurship (cf. Reuter, 1983: 113-117). First, the environment in which criminal entrepreneurs operate is unregulated. There are no formal procedures to revert to, such as regarding drafting a contract, there is no mediating, judging authority that offers a solution when a disagreement occurs, and there is no possibility to insure oneself against unexpected setbacks. Second, criminal entrepreneurs run risks as a consequence of the activities of the police and the law. These risks consist of seizures, arrests and imposed punishment. Even when it is not the criminal himself who falls 'victim' to a criminal investigation, but a relation such as the foreign drug supplier, this may pose serious problems to the criminal's own entrepreneurship. Third, partly because of the lack of regulation, the colleagues of a criminal entrepreneur, his fellow offenders, constitute an important risk factor. Fellow offenders may betray the criminal entrepreneur, may steel from him or may not keep to agreements in other ways. A business partner may also prove to be incompetent, such as because he turns out to be less well connected or have less financial means than he has made it appear. After all, there is no public quality assessment regarding criminal entrepreneurs. All in all, many things may go wrong. This is especially true for complex activities such as transnational criminal activities, whereby the chain of the criminal process involves many links. A European who wants to import and trade cocaine, for example, has to take care, either directly or indirectly, of the following links: its transportation from South America to Europe; its importation into Europe; its initial transportation and storage here; its further processing (adulteration); and its delivery at the next buyer's. All these links harbour risks: the cocaine may not arrive (properly); it may 'disappear' during its importation or further transportation; it may get adulterated with the wrong substances or in the wrong proportion; or it may turn out that, in the end, there is no buyer. In addition, when something goes wrong, it is often unclear whether this is the result of ill intentions, incompetence or a misunderstanding - have the drugs indeed been seized through unsuspected police attention, or has the driver simply stolen the consignment, or has he got caught because of his stupid, amateurish behaviour? All in all, criminals have reason enough to distrust one another.

Because of these risks, criminal entrepreneurship is surrounded by great insecurity and unpredictability, and so are the undercover operations that target criminal entrepreneurs. As mentioned above, the unpredictability especially holds for undercover buys. Of the 34 undercover operations started in 2004, 15 focused (among other things) on bringing about one or more undercover buys. Of these 15 operations, ten did not work out according to plan. We present a taxonomy of undercover buys that passed off differently from expected: 
- Either an undercover buy does not take place at all because:

- the suspect in the end turned out to be unable to deliver, as happened in a case in which a concrete deal had been struck with the suspect, but on the day the actual buy should have taken place, the suspect turned out to be unable to supply the drugs;

- the suspect in the end turned out to be unwilling to deliver, as in a case in which the subject initially seemed willing to do business, but in the end was too suspicious to go through with it;

- the suspect repeatedly did not show up at arranged meetings;

- the goods were found to be sold to another buyer;

- the circumstances indicated that the suspect may have intended to close a rip deal instead of a deal, which means that the suspect did not actually intend to sell anything to the undercover agent, but intended to rob him.

- Or the undercover buy does take place, but:

- the size of the undercover buy is smaller than originally expected because the subject is unable to live up to his promises - 'I can deliver a whole container, no problem'.

The fact that undercover buys often do not work out 'as planned' does not automatically mean that an undercover operation has failed entirely and has not contributed in any way to the investigation and/or trial. Of course, an undercover buy that does take place but not quite as expected can still generate evidence. Even an undercover buy that never actually takes place may nevertheless yield proof. ${ }^{61}$ In general, however, unexpected developments do have a negative influence on undercover operations: they cause operations to last longer or to lack intended results. Because of the great frequency with which commitments are not kept, trade qualifications turn out to be false or undercover buys do not meet the expectations in other ways, it certainly is not easy to 'do business' with criminals efficiently.

\subsection{Undercover operations and the court}

In addition to the contributions made by undercover operations to investigations and trials, the 'legal tenability' of this investigative instrument might also be understood as being a part of the 'results'. During criminal trials, how do judges respond to the plea put forward by the defence regarding undercover operations?

\footnotetext{
${ }^{61}$ In one case, for instance, a suspect has been convicted for preparing a drug delivery to an undercover agent, even though in the end, the delivery fell through because of logistic problems on the suspect's side.
} 
To answer this question, we have examined Dutch case law. In total, we have studied more than 60 court decisions in cases involving an undercover operation. ${ }^{62}$ The two most important grounds of defence that lawyers have put up in these cases related to alleged entrapment (argued in 30 cases) and incompatibility with the principles of proportionality and subsidiarity (argued in 17 cases). ${ }^{63}$ The vast majority of pleas on these and other grounds have been dismissed by the judges. Transparency is of great importance in this context, namely the extent to which the police and the Public Prosecution Service provide information on the considerations that were decisive in the use of an undercover operation, the circumstances under which the operation has been carried out and the findings the operation has yielded.

When this transparency is present, the pleas put forward by the defence are not often judged to be valid. In the small number of cases in which a plea has been accepted, the reason has often been the inadequate reporting of and poor insight given into the undercover operation and consequently the judge's inability to verify the operation's legitimacy. In the great majority of the cases that we have studied, the judge's opinion was that he had been presented with a good picture of the way in which the undercover operation had been carried out. In the same vein, earlier research has shown that Dutch judges are of the opinion that they have gained more insight into the application of the special powers of criminal investigation since the introduction of the BOB Act (Beijer et al., 2004: 282). This Act prescribes that the use of investigative instruments in a criminal case must be transparent and verifiable. Before the introduction of this act, judges often were not even informed about the simple fact that an undercover operation had been part of a particular criminal investigation (Van Traa, 1997: 16).

\subsection{Discussion}

In this chapter, we have given an account of empirical research into undercover operations. We have made use of two data sources: (1) a unique insight into the execution and results of all undercover operations carried out in the Netherlands in 2004; and (2) the available Dutch case law regarding undercover operations. We will briefly summarize our most important findings. First, it has become clear how scarcely undercover operations are carried out in the Netherlands: 34 times in 2004. Thus, these operations represent a method of investigation that is not often applied. This may be caused by the fact that in the Netherlands, contrary to the United States (Ross, 2007: 512-513, 562-563), especially the more controversial forms of undercover operations can only be used when other investigative instruments have failed, although legislation does not explicitly prescribe that undercover operations in general are only to be used as a last resort. It may be possible, of course, that there is

\footnotetext{
62 An overview of the case law studied is included in the references.

63 When the court permits such a plea, the court has discretionary power to choose one of the following remedies: mitigation of the sentence, exclusion of evidence, or dismissal of the case.
} 
simply no need for a more frequent use of undercover operations. Interviews with police and judicial practitioners have revealed that other factors play a role as well. One of these factors is the limited knowledge of and experience with undercover operations at the Public Prosecution Service and in the police force. Precisely because it is so rarely used, covert police operations are sometimes simply overlooked during criminal investigations. In addition, due to the IRT affair and its aftermath, some public prosecutors view undercover operations as a very invasive and drastic method of investigation that is only to be used as a last resort. Finally, some prosecutors fear that by opting for an undercover operation, especially where infiltration is concerned, they will lose control, because the deployment of this investigative method requires the authorisation of higher echelons within the Public Prosecution Service (and feedback on a regular basis; see chapter 3).

Second, we have mapped out how many and what sort of results undercover operations generate. Of the 34 cases in 2004 in which an undercover operation was used, in seven cases, the operation provided evidence that has been used in convicting the suspect(s). In four cases, the undercover operation has resulted in exclusion, which means that the investigation team has grown convinced, based on the information gathered during the undercover operation, that the suspicion against someone was partly or completely untrue. In one case, the undercover operation has resulted neither in evidence nor in inclusion, but 'only' in steering information. In total, the undercover operation instrument has contributed to an investigation and/or trial in 12 cases, while it has failed to contribute anything in 22 cases.

Third, the course of undercover operations turns out to be very unpredictable. This unpredictability is worst during operations in which undercover buys play a role, such as in many investigations into the trading of drugs, weapons or stolen property. Because undercover agents often pose as fellow criminals in these operations, who are game for a good deal, they are confronted with the unreliable and unpredictable behaviour common to the criminal entrepreneurial market.

Fourth, readings of Dutch case law suggest that transparent reporting on an undercover operation is of crucial importance for the outcome of the legitimacy test that is carried out by Dutch judges. When both the Public Prosecution Service and the police provide sufficient insight into the background, the execution and the results of an undercover operation, the objections put forward by the defence against the use of this means are usually dismissed and the operation is judged to be legitimate. According to the assessment of Dutch judges, the stipulated condition of transparency for criminal cases has been fulfilled.

Fifth, we have examined three assumptions that are inherent in legal and/or academic discourses, the first being the supposition that undercover agents have the power to completely determine their interactions with the subject. It is true that undercover operations involve an undercover agent who misleads the suspect. Yet, the idea that the undercover agent is the one who completely dominates the course of the operation passes over the fact 
that in many operations, the undercover agent himself is subjected to the unpredictability of criminals. Especially during operations focusing on suspects of the trade in drugs, firearms or stolen goods, the practical course taken by an operation is to a large extent determined by the unpredictable behaviour of the suspect(s).

A second assumption relates to the results of undercover operations. From the academic literature, it appears that these results are only made up of arrests, convictions and seizures. This idea is founded on a conception of an investigation as a linear process, leading from a suspicion to a conviction. Our research shows, however, that undercover operations may not only lead to the arrest of a suspect, but also to his or her exclusion from further investigation. Furthermore, an operation may also yield steering information. Thus, the reality of criminal investigation is less linear and should preferably be viewed as a more open process focused on establishing the truth.

A third assumption is at the foundation of the Dutch legislation regarding undercover operations. It relates to the distinction made by the legislator between three different undercover powers: systematic intelligence gathering, undercover buys and infiltration. The legal conditions stipulated for infiltration are stricter than those stipulated for undercover buys, while the conditions for this latter power are stricter than those for systematic intelligence gathering. The underlying supposition is that systematic intelligence gathering, that 'only' entails the gathering of information, is less invasive and risky than infiltration, during which an undercover agent actually becomes part of a criminal organization. In the investigative practice, however, the application of systematic intelligence gathering has frequently proven to be more invasive than infiltration. The reason for this is that in some cases of systematic intelligence gathering, the undercover agent needs to get very close to a suspect, while during infiltration, the contact more often stays limited to a businesslike level. Infiltration is mainly used to investigate the drugs and arms trade. An undercover agent tries to infiltrate a group of suspects trading in those goods. The agent's assignment most often is to get a clear picture of the criminal organization and to attain a position within the group that is favourable for setting up the buy of a substantial batch of drugs or weapons. In order to achieve that, the suspects have to be convinced that the undercover agent is a capable business partner, namely someone who has something to offer, such as certain facilities that come in useful in the drug trade or simply a lot of capital to purchase drugs from the suspects. In order to do business with the undercover agent, the suspects also have to perceive him as reliable: will he meet his commitments, without cheating on them? Although it will certainly help if the suspects and undercover agent more or less like each other on a personal level, the main issues here, namely competence and reliability, relate to a more 'professional' level.

Systematic intelligence gathering, on the other hand, is often used to gather information about a suspect's involvement in crimes such as murder. When an undercover agent is deployed to find out whether a man has killed his wife, for instance, he must 
try to build up a totally different relation to the suspect than if he were involved in a drugs investigation. Often, the undercover agent has to see to it that the suspect trusts him personally, like a friend, in order to get him to talk. Building a friendly relationship and then betraying this 'friendship' by stating damaging information about this man can be much more psychologically taxing to an undercover agent than playing the role of a drug dealer in a drugs investigation (Beijer et al., 2004: 103-104). In this way, the execution of the type of undercover operation for which the legislator has stipulated the lightest conditions (systematic intelligence gathering) may have more dramatic consequences, for both undercover agent and suspect, than the execution of the legally most serious undercover operation (infiltration). Although this empirical result relates specifically to the Dutch legislation, it leads to a conclusion of broader relevance: rather detailed regulation and judicial distinctions may not be attuned to investigative practice.

Thus, these assumptions are not in line with our empirical results. The most important lesson to be drawn from this is that there is a need for more generally accessible information on this investigative instrument: how often is this means applied, for which crimes, in which forms (e.g. undercover buys, befriending operations), and how many and what sort of results do undercover operations yield? Not only scholars, but also Parliament does not have this information. For the verifiability of undercover operations, however, it is essential to gain empirical insight into the matters we have mentioned. It would provide scholars with a foundation for critical perspectives and discussions. Most importantly of all, it would enable regulatory bodies to monitor the deployment of this method of investigation and, whenever necessary, make well-informed decisions regarding legislation and guidelines. Thus, transparency may serve as an alternative for policy instruments arising from the understandable need to have control over the police, but that at the same time relate badly to the complex, unpredictable character of criminal investigations in general and undercover operations in particular. 


\section{Infiltrating organized crime groups: theory, regulation and results of a last resort method of investigation}

This chapter gives insight into the Dutch investigative practice of a specific type of undercover police strategy: infiltration ${ }^{64}$. Infiltration is legally the most serious kind of undercover operation, which is mainly deployed against organized crime. Based on research covering all infiltration operations in the Netherlands during the 2000-2005 period, this chapter provides empirical insight into the use of this 'last resort' method of investigation. It looks into the numbers, course and results of infiltration operations but also into the practical outcomes of formal, regulatory requirements.

\subsection{Introduction}

The purpose of this chapter is to give empirical insight into the investigative practice in the Netherlands of an undercover police strategy that is used against organized crime: infiltration. During an infiltration operation, an undercover police officer (undercover agent) takes part in a criminal organization or a criminal group.

Organized crime, as a policy issue, has a prominent position on the political agenda. As a topic of scientific research, organized crime also has a history that spans several decades (Paoli and Fijnaut, 2004a; Kleemans, 2012). However, when it comes to investigative methods that are used against organized crime, empirical research is scarce.

For criminologists, criminal investigation is a relatively neglected field of research, especially when organized crime is concerned (Grabosky, 2010: 364; see also De Poot, 2010: 102). When looking at the most-cited scholars and their most-cited works, it is clear that criminologists focus on criminals (and their treatment) rather than on criminal

\footnotetext{
${ }^{64}$ A slightly different version of this chapter was earlier published as: Kruisbergen, E.W. (2013). Infiltrating organized crime groups. Theory, regulation and results of a last resort method of investigation, Cahier Politiestudies, 20133/28: 109-136.
} 
investigation (Cohn and Farrington, 2012). ${ }^{65}$ Others, e.g. Brown et al. (2012: 1), have pointed out the fact that the evidence base on how the investigative process works is growing, but that research on investigative methods focuses on scientific techniques such as use of DNA or fingerprints. Research on other methods of investigation is rare.

Those other methods include proactive methods of investigation such as wiretapping, surveillance, and undercover policing. The deployment of proactive policing strategies was stimulated by the rise of organized crime groups during the 1960s and 1970s (Fijnaut and Marx, 1995a: 15-16; see section 3.2). In many countries, the use of proactive methods of investigation has been the subject of heated debate (see section 3.3). Furthermore, it has served as an important driving force behind the growing attention for police governance and accountability (Walsh and Conway, 2011: 61). The need to control police activity, as expressed in academic and legislative debates, is especially strong where controversial methods such as undercover policing are concerned.

Although there certainly are scientific publications on the subject, little empirical research has been done on undercover policing (Smith et al., 2009; Brodeur, 1992: 108; Giacomantonio, 2011: 453) ${ }^{66}$ Loftus and Goold assume that this lack of empirical knowledge is probably due in part to the police desire to protect this covert and deceptive method of investigation (Loftus and Goold, 2011: 276-277, 286) ${ }^{67}$ Because of this criminological gap very little is known about the results that undercover operations yield for criminal investigations. Also, there is little knowledge of the outcomes regulatory procedures produce in the investigative practice. As a consequence, debates on police powers lack empirical evidence.

In the Netherlands, infiltration is the legally most serious undercover power (in section 3.3, we will elaborate on the legislation). Infiltration is only permitted in investigations targeting the most serious crimes and only if other investigative methods have proven (or are expected to be) ineffective. Infiltration is mainly used against organized crime. Besides conditions regarding proportionality and subsidiarity, an investigation team has to comply with strict authorization procedures; infiltration requires the approval of the highest level of authorization within the Public Prosecution Service.

${ }_{65}$ Among the most popular subjects are criminal careers, effectiveness of correctional treatment, and causes of delinquency.

${ }_{66}$ According to Ross, there is a 'plethora of critical perspectives' (Ross, 2008: 240). An important part of the literature looks upon the subject from a judicial and/or normative, critical point of view. Many studies focus on the issue of entrapment in buy-bust and sting operations. Basically, entrapment concerns the question whether an undercover operation actually tackles real criminals or whether such an operation incites individuals to commit a crime who did not have any criminal intent to begin with (e.g. Allen et al., 1999; Ashworth, 2002; Colquitt, 2004; Dillof, 2004).

67 A number of American studies provide information on the results of specific types of sting operations (cf. Roberts, 2000: 272). Some examples: Bowers and McCullough (1982) and Langworthy (1989) evaluated police anti-fencing operations; Webster et al. (2006) studied stings that targeted the spread of firearms from the legal arms trade into the underworld; and Mitchell et al. (2005) studied operations in which undercover agents posed as minors in online chat sessions, in order to trace potential sex offenders (see also Fulda, 2002). Yet, very little is known about the practice and results of undercover operations as an investigative instrument in general. 
In this chapter, unique data are used to provide empirical insight into the numbers, course and results of infiltration operations as well as into the practical implementation of the regulatory requirements.

The following research questions will be addressed: How often are infiltration operations deployed? What results have these operations produced? And what outcomes do the regulatory requirements produce in the investigative practice? To answer these research questions we use data on all infiltration operations in the Netherlands during a six-year period, 2000-2005.

In section 3.2, we will elaborate on undercover policing as a method of criminal investigation. In section 3.3, we will examine the legislative debate regarding undercover policing. In section 3.4, we will elaborate on empirical data and methodology. Section 3.5 provides empirical insight into the deployment of this policing method: the numbers, course and results of infiltration operations in the Netherlands in the 2000-2005 period. In section 3.6 we will look more in depth into the investigative practice of infiltration operations. That section provides an analysis of the unpredictable course of infiltration operations, as well as an analysis of the possible outcomes that regulatory procedures may produce. In section 3.7, we will summarize the findings and discuss some implications.

\subsection{Undercover policing}

Proactive methods of investigation such as wiretapping, surveillance, the use of informers and undercover policing, share their covert nature as a common feature. Subjects are unaware of their deployment, as opposed to methods such as arrests, house searches and interrogations, which cannot be used without subjects knowing it. However, in contrast with wiretapping and surveillance, undercover police operations (as well as the use of informers) are not only covert but also deceptive. An undercover agent, for example, poses as a 'friend' or 'fellow criminal', tries to gain the trust of the suspect and uses his cover to gather evidence or other information. Another distinctive characteristic of undercover agents is that, in some cases, they participate in the very crimes that are under investigation (Ross, 2008: 239). Such is often the case in infiltration operations, when for example an undercover agent joins a criminal organization involved in drug trafficking. These specific features bring with them certain investigative opportunities as well as certain risks. They are also the reason why undercover policing is controversial.

In this section, we will elaborate on undercover policing as a method of criminal investigation deployed against organized crime (3.2.1). However, the use of undercover methods is much older and has served much more purposes than the fight against organized crime (Paoli and Fijnaut, 2004a; also see Von Lampe, 2001). The second part of this section will therefore provide a brief historical perspective on undercover methods (3.2.2). 


\subsubsection{Policing organized crime}

'Modern policing no longer relies solely on detection, confession and the hope that witnesses will come forward. Increasingly, law enforcement agencies in the United Kingdom and in other countries are turning to pro-active, intelligence-led methods such as the use of surveillance devices, informants and undercover officers'

(Noorlander, 1998: 49; see also Martellozzo, 2012: 113).

Proactive investigative methods have become increasingly important. This shift is caused by the rise of organized crime and growing concerns about terrorism (Harfield, 2008: 64; Roberts, 2007: 99; Maguire and John, 1996: 316-318; Fyfe and Sheptycki, 2006: 319-320; Paoli and Fijnaut, 2004b: 1043). The nature of organized crime in the Netherlands has been described as transit crime; criminal groups are primarily involved in international illegal trade. The major business of organized crime groups in the Netherlands comes down to international smuggling activities. The Netherlands can be either a country of destination, a transit country, or, in the case of synthetic drugs and cannabis, a production country (Kleemans, 2004, 2007). ${ }^{68}$ Parties involved in these types of organized crime (often) participate with mutual consent. The wholesale drug trafficker, the airport employee who offers drug traffickers a 'safe passage' through airport security, the lower level drug dealer and his customers, and the financial specialist who provides money laundering services, they all act out of free will and - except for the customers - are driven by financial profit ${ }^{69}$. Therefore, organized crime, unlike traditional crimes such as burglary or rape, for that matter, does not generate victim reports. ${ }^{70}$ As a consequence, reactive policing, which is primarily instigated by victim reports and criminal events and behaviour in the past, becomes inadequate and is increasingly replaced by proactive policing, which focuses on gathering evidence about the current and future behaviour of offenders. Instruments that are used as proactive methods of investigation are, among others: wiretapping, surveillance, the use of informers, and undercover policing. ${ }^{71}$

Some proactive policing methods can be deployed without the police, or other people on behalf of the police (informers), actively interacting with criminals. When the police keep a suspect under observation and tap his telephone calls, they, in a sense, deploy

68 Synthetic drugs and cannabis that are produced in the Netherlands are not only used for international trade. The drugs are also distributed on the Dutch market.

${ }^{69}$ Of course there are cases in which people are forced to cooperate. The point here is that, due to the opportunity to earn 'quick money', there are many willing perpetrators.

70 Some types of organized crime, such as the production of synthetic drugs, do produce 'crime scenes'. Others, such as drug trafficking, do not.

71 Wiretapping, surveillance, informers and undercover policing can also be deployed in reactive criminal investigations. Undercover operations, for example, have been used in investigations regarding, among other crimes, murder and missing people (see section 3.2.2). 
passive methods of investigation. They follow the suspect and listen in to his conversations. However, some crimes may be hard to perceive by using these methods. Offenders in organized crime generally try to conceal their activities. They may, for example, change means of transportation when travelling from one location to another or use concealed language. ${ }^{72}$ In those cases the police might want to use a more active approach, i.e. informers or undercover agents who interact with the targets.

In many cases informers are actively involved in crime. Some consider these so-called participating informers as the best informers (Billingsley et al., 2001a: 6). Being criminals themselves, they produce the most valuable information. Using informers, however, has certain important drawbacks as well. Precisely because informers often are themselves criminals, they have their own agendas. As a consequence, they are less reliable. Also, it can be conceived as irresponsible to expose civilians to the risks involved in (befriending and) betraying criminals. Furthermore, the use of civilians might be limited by law, as is the case in the Netherlands.

Reliability is much less an issue when one uses specialized police officers: undercover agents. Also, since undercover agents are trained professionals, the risks involved may be more controllable (Billingsley, 2001: 81-97; Greer, 2001: 125; Billingsley, 2008: xv-xvii). When using undercover agents, one of the main disadvantages relates to the fact that the undercover agent lacks a criminal identity. An undercover agent (or the police undercover unit) has to create a cover story and find a way to make contact with his target(s).

When developing a strategy for an infiltration operation, the police benefit from the fact that organized crime is dependent on social relations.

\section{Undercover policing and the social embeddedness of organized crime}

The social network approach on organized crime stresses the fact that criminal entrepreneurs thrive and are dependent on social capital. Social relations dissolve problems of co-operation in an unfriendly environment. Offenders operate in a hostile and uncertain habitat. Due to the illegality of their activities, there are no formal rules and arrangements to revert to, such as those regarding contracts, there is no mediating, judging authority to turn to in case of disagreement, and an offender cannot insure himself against unexpected setbacks. Furthermore, criminal entrepreneurs run risks because of police activity: assets can be seized and people can be arrested at any moment. And, last but not least, the colleagues of a criminal entrepreneur constitute an important risk factor. Those 'colleagues' are not bound by any regulation and there is no public quality assessment regarding criminal entrepreneurs. They may steel from him, betray him or may prove to be incompetent (cf. Reuter, 1983: 113-117; Kleemans, 2014b). These problems of distrust are mitigated through

Under those circumstances surveillance or wiretapping may still generate relevant information (although perhaps not evidence). 
the 'social embeddedness' of transactions, i.e. transactions take place within networks of personal relations (Kleemans, 2014b; Kleemans and Van de Bunt, 1999). In many cases of organized crime it turns out that family, friends and acquaintances work together and introduce each other to third parties.

Not only do social relations dissolve problems of co-operation in an unfriendly environment, they may also offer new opportunities through the use of each other's resources. By making use of his social network, an offender may enhance his financial or logistic power, he may be introduced to new potential partners, and/or he may gain access to new markets. The most valuable relations are those that enable an offender to bridge 'structural holes', i.e. to form a connection between (parts of) networks that are poorly connected as a consequence of geographical, social and/or ethnic barriers between different countries, groups, and between the underworld and the licit world (Burt, 1992; Kleemans, 2007).

The social network approach is of value here because it clarifies what an undercover agent must do when targeting offenders involved in organized crime. An undercover agent must penetrate the offenders' social network. He must somehow make contact with the target or his entourage and make his target believe that he is a capable and reliable partner. An offender, when looking for possibilities to enlarge his operational scope, might consider the undercover agent an asset to his network, provided the agent uses the right cover.

If an undercover agent succeeds in infiltrating an organized crime group, his participation in the group may prove very useful for the criminal investigation and trial. When an undercover agent, for instance, buys several kilos of cocaine from a suspect, this generally serves as very convincing evidence, i.e. evidence that is much more unequivocal than, for example, a monitored telephone conversation during which suspects constantly talk about drinking 'coffee with milk'. However, realizing a successful undercover buy may prove to be quite a task, since, as will be clear when discussing the results of infiltration operations (sections 3.5.3 and 3.6.1), participation in criminal markets carries its own problems.

\subsubsection{Undercover policing in historical perspective: from Judas to 'Mr. Big'}

Undercover methods are certainly not new. Spies and informers have been used for centuries to gather information on adversaries or to sabotage their actions. Such methods were deployed, for instance, by the Romans (Gibbon, 1831). A well-known example of undercover tactics can be found in the Bible; Judas, as one of Jesus' disciples, was turned into an informer and the information he passed on to the authorities led to the arrest of his master.

It was not until the emergence of more or less modern police organizations, however, that the systematic use of undercover policing became possible (Marx, 1988: 17). A modern police organization was first created in Paris at the end of the seventeenth century. Initially, undercover methods were deployed in particular to protect political and economic interests, 
but later they were used in operations targeting regular crime as well. Twenty inspecteurs de police of the notorious bureau de surêté formed a well-developed undercover unit. During undercover operations the inspecteurs gathered information on citizens in both political and criminal matters.

In the eighteenth-century United Kingdom, undercover operations were executed by citizens as well as by police officers. In the thief-taker system, citizens - thief takers, many of whom were themselves criminals - recovered stolen property for a reward. Undercover tactics were also used by officers of what is often called London's first modern police force, the Bow Street Runners (Fijnaut and Marx, 1995a: 2-16; Goddard, 1957). An early example of an undercover operation used by the police in the Netherlands dates back to 1846, when a police officer of the city of The Hague infiltrated a group of counterfeiters (Blaauw, in Frielink, 1990: 9).

The use of undercover operations in criminal investigations, as opposed to the deployment of undercover methods for state security reasons, increased from the $1960 \mathrm{~s}$ onwards as a result of a rise of organized crime groups. ${ }^{73}$ As the fight against drug trafficking became more prominent, the police in the United States used undercover agents on a large scale, mainly in the form of so-called buy-bust operations. During a buy-bust operation, the police create the opportunity for someone to commit a crime, such as when an undercover agent poses as someone who wants to buy drugs. When the American Drugs Enforcement Administration (DEA) exported President Nixon's war on drugs to Western Europe, the use of undercover methods by the police increased in Europe as well (Ross, 2008: 241; Fijnaut and Marx, 1995a: 15-16).

However, undercover policing is not limited to drug investigations, nor is it exclusively used in organized crime investigations. Undercover operations are directed against a broad range of crimes, such as drug trafficking, arms trafficking, evasion of excises, property crimes, murder and other violent crimes, and sex crimes. In the United States, so-called sting operations have been deployed for over forty years. A well-known type of sting operation is the use of false storefronts, directed at property crimes. Undercover agents may pose, for instance, as pawnbrokers who are willing to buy stolen property (Newman, 2007: 1, 7; Marx, 1988: 108-128). In the Netherlands, undercover operations are also deployed against property crimes, e.g. undercover agents purchasing goods from online suppliers of stolen property (Kruisbergen and De Jong, 2010: 144). Cyberspace offers a lot of possibilities, for criminals as well as for the police. Undercover agents, for instance,

73 This does not mean that the use of undercover methods for state security purposes was abolished. In the United States, the FBI used undercover operations during the 1920s and 1930s in the fight against espionage and sabotage committed by communist and fascist groups (Fijnaut and Marx, 1995a: 10-14). In the same period, and for the same reason, the political use of undercover policing increased in Europe as well (Marx, 1988: 22-32). After World War II, undercover methods initially became discredited in Europa because Nazi Germany and the communist USSR had made large-scale use of these methods in suppressing their own population. However, the heat of the Cold War again induced deployment of undercover tactics for state security purposes. 
may pose as juveniles in order to catch online sex offenders, as is done, for instance, in the United States and the United Kingdom (Mitchell et al., 2005: 251-256; Martellozzo, 2012). Moreover, in the Netherlands as well as in other countries, undercover operations are deployed in investigations into murder and other violent crimes. In these 'befriending' operations, an undercover investigator tries to build up such a relationship with a suspect that the latter confides his guilt to his 'friend' (Kruisbergen and De Jong, 2010: 143-144; Maguire and John, 1996: 316-318; Choo and Mellors, 1995; Smith et al., 2009: 169-170).

A specific application of befriending is the so-called ' $M r$. Big' technique, which is used by the Canadian police in murder investigations, among others. Usually undercover agents posing as members of a criminal organization befriend the suspect and suggest that he may join their gang. Then the undercover agents involve the suspect in minor crimes, perhaps even pay him for his activities, and display evidence of wealth. Once the suspect is committed to the organization, he is offered a higher level job. But first the suspect is to be subjected to a job interview with the organization's leader, 'Mr. Big'. Furthermore, before becoming a full-fledged member, the suspect must confess to a crime he is said to have committed, i.e. the crime that is under investigation, usually murder. The suspect is told that his candour is required as a form of 'insurance' - so they have something on him if he ever betrays them. Another reason might be that 'Mr. Big', once he knows the truth, can pull some strings to make the evidence against the suspect disappear (Smith et al., 2009: 169-170). According to estimations, the technique has been used hundreds of times across Canada (Puddister and Riddell, 2012: 386). Variations of ' $M r$. Big' have also been used by the Australian police as well as the Dutch police (Stuesser, 2008). ${ }^{74}$

Thus, undercover operations are deployed in criminal investigations targeting a broad range of crimes. This also applies to the Netherlands, where, as mentioned earlier, undercover operations are used against drug trafficking and illegal arms trade, but also in murder and property crime investigations, among others. Infiltration, however, the most serious kind of undercover police power in the Dutch code of criminal procedure, is mainly used against organized crime.

\subsection{Regulation of undercover policing}

The last three decades have shown a growth in the instruments used to enhance the control of police activities. Policing is increasingly subjected to formal statutory regulation, both in common law jurisdictions such as England and Wales, and in civil (continental) law jurisdictions such as Belgium and the Netherlands (Kruisbergen, Kleemans et al., 2012; Roberts, 2007: 97-102; De Roy and Van Dromme, 2004; Traest and Meese, 2000).

74 A variation of the 'Mr. Big' technique has been used, for example, in a very recent Dutch murder case, the Heidy Goedhart case. 
Furthermore, in some countries, including the Netherlands, authority over criminal investigations has been centralized (Van de Bunt, 2004: 711-712; Terpstra, 2011; Terpstra and Van der Vijver, 2005; Jongeneel-Van Amerongen, 1997: 62-63). ${ }^{75}$ Outright scandals, incidents and specific criminal cases are important impetuses behind 'the flood of rules on investigative powers', as some put it (Groenhuijsen and Kooijmans, 2011: 62).

\subsubsection{Affairs and legislative debate}

In the United Kingdom, the case of Khan played a significant role in the regulation of police powers. ${ }^{76}$ In the Khan case, the police attached monitoring equipment to the outside wall of a house. The House of Lords criticized the fact that such an invasive investigative method was deployed in the absence of any legislation. The Khan case was one of the catalysts behind the Police Act 1997.

In Belgium, undercover policing became discredited as a result of the François scandal, that took place in the 1970s. Léon François, a Rijkswacht (federal police) captain, was the head of a special police unit that deployed undercover operations against drug trafficking. During an undercover buy, François lost roughly $€ 41,000$. To cover up his failure, François wrote a false report regarding this action. Furthermore, to close the gap in his budget that resulted from the failed undercover buy, he withheld cocaine during following operations. When he had 'saved' two kilos of cocaine, he arranged to sell the drugs to a Dutch drug trafficker. The 'drug trafficker', however, turned out to be a member of a Dutch undercover unit. François and some fellow policemen were arrested and tried (Fijnaut, 1983: 93; Van Oss, 1994: 1-2). In the 1980s, possibly as a result of the François scandal, as Frielink (1990: 115) assumes, conditions regarding undercover operations were laid down in Belgian case law. ${ }^{77}$ Today, investigative methods, including undercover policing, are regulated by the Act on Special Investigative Police Methods (BOM Act), that came into force in 2003 (De Roy and Van Dromme, 2004).

The course of the Dutch legislative debate was defined by the IRT affair. The Interregional Investigation Squads (IRTs) were established in the fight against organized

75 In the Netherlands, the organizational structure of the police force has been subjected to change and political debate since the early nineteenth century (Croes, 2005). Effective as from 2013, the Dutch have one national police force.

76 R. v. Khan (1996) 3 All ER 289.

77 Three other crises in Belgium had a major impact on public opinion and the political debate regarding the police. These were the Heysel Stadium Disaster (1985, rioting before a soccer match and poor crowd control resulted in 39 dead); the events involving the Nijvel Gang (Bende van Nijvel; 1983-1987, an extremely violent gang that raided supermarkets, killing 29 customers); and the Dutroux case (1995-1996, Marc Dutroux kidnapped, abused and killed several children). These affairs, however, did not involve the deployment of specific methods of investigation, as opposed to the François incident, which centred on undercover policing. Rather, they centred on a lack of police competence. All three affairs resulted in a parliamentary inquiry committee and these inquiry committees all reached the conclusion that the police had failed in handling the crisis. Several organizational police reforms were introduced in the aftermath of the crises (Enhus and Ponsaers, 2005: 345-346). 
crime in the early 1990s. The IRTs deployed 'experimental' methods of investigation. After the sudden dismantling of the Amsterdam-Utrecht IRT in 1993 and internal disputes within the police, a Parliamentary Inquiry Committee on Criminal Investigation Methods (in Dutch: Parlementaire Enquêtecommissie Opsporingsmethoden (PEO)) was set up. The committee concluded that some of the new investigative methods were unacceptable (PEO, 1996, Eindrapport). Several tons of drugs had been imported under the supervision of the authorities, in the hope that so-called 'growth informers' would rise to what was alleged to be the top of criminal organizations. The informers, themselves criminals, were assisted by the police and the customs to pose as trustworthy and successful criminal entrepreneurs. The committee, however, questioned whether the police were running the informers or vice versa. Furthermore, the committee concluded that there was a legal vacuum regarding methods of investigative methods such as undercover policing and surveillance. In the Netherlands, until 2000, the code of criminal procedure lacked specific sections that covered such intrusive techniques. Another major conclusion of the committee was that the command and control of criminal investigations should be improved. The committee's report provided the foundation for the new Act on Special Investigative Police Powers (in Dutch: Wet bijzondere opsporingsbevoegdheden (BOB Act)), effective as from 2000. The BOB Act regulates several investigative powers, strengthens the authority of the Public Prosecution Service in criminal investigations, and requires accountability at trial for the deployment of investigative powers (Kleemans, 2007: $164-165) .^{78}$

In the following section, we will look into the BOB Act and additional authorization procedures concerning undercover operations in the Netherlands.

\subsubsection{Regulation in the Netherlands}

Since the BOB Act came into effect, participation in criminal activities by police officers or by civilians working under supervision of the police, has to comply with laws and regulations, and in some cases it is forbidden. The Act requires that illegal goods or substances that constitute a risk to public health or public safety, such as drugs or weapons, be confiscated (Beijer et al., 2004: 278). Therefore, it is, in principle, not allowed to 'supervise' the importation of drugs, as the IRT did.

78 In other countries, incidents and affairs played a key role in the legislative debate as well. In the United States, the so-called ABSCAM ( $A b d u l$ Scam) led to a controversy. ABSCAM was an undercover operation run by the FBI, which ran in the late 1970s. It was a typical 'fishing expedition' or 'honey pot operation', i.e. it was not directed at specific suspects but rather targeted a category of persons. It involved undercover agents who tried to bribe members of Congress. The operation resulted in several convictions but it was criticized as well. In the aftermath of ABSCAM, Congress considered the introduction of an Undercover Act, but the bill was never put to the vote. However, the Department of Justice did issue The Attorney General Guidelines for FBI Undercover Operations (Gershman, 1982: 1585-1586). 
In regulating undercover operations, the Dutch legislator opted for a three-fold division of powers in the BOB Act (Kruisbergen, Kleemans et al., 2012: 401-402). The code of criminal procedure distinguishes between systematic intelligence gathering, the purchase of illegal goods or substances or the rendering of illegal services (undercover buys), and infiltration. An infiltration operation may - and often does - involve one or several undercover buys.

The deployment of infiltration is assumed to involve more risks than the deployment of an undercover buy, which in turn is assumed to be more risky than the deployment of systematic intelligence gathering. The underlying idea is that during infiltration, the undercover agent actually becomes a member of a criminal organization. Not only is joining a criminal organization a crime but, as the legislator summarizes the risks, it also entails the risk of moral contamination of the police officer by the criminal environment, as well as risks concerning the physical safety of the undercover agent and his relatives. When an undercover buy is used, an undercover agent also participates in a crime. However, that participation is less far-reaching and less sustained than is the case with infiltration. Systematic intelligence gathering is assumed the least risky because the undercover agent 'only' collects information and does not participate in any crimes. ${ }^{79}$

The legal requirements for the deployment of the undercover powers differ in accordance with the assumed level of risk attached to them. Infiltration is only allowed in investigations targeting the most severe crimes (proportionality) and only if other investigative methods have proven (or are expected to be) ineffective (subsidiarity). The other two undercover powers (undercover buys and systematic intelligence gathering), however, may be deployed against a (much) broader category of crimes and without an exhaustive exploration of alternative methods of investigation.

Civilians may be used in undercover operations to gather information, to deploy an undercover buy or to deploy an infiltration operation. The use of civilians for undercover buys and infiltration operations, however, is permitted only if police officers are not capable of deploying the operation. In the case of infiltration, the use of criminal civilians was initially forbidden. ${ }^{80}$ Later on, in the aftermath of $9 / 11$, the ban on criminal civilian infiltrators was slightly loosened when the Dutch Minister of Justice deemed the use of criminal civilians permissible in terrorism investigations (Tweede Kamer, 2002-2003, 27 834, no. 28). In 2013, the ban was loosened still a bit further. In 'very exceptional cases'

79 In practice, however, systematic intelligence gathering may be more invasive than infiltration, for both undercover agent and suspect. This is due to the fact that in some cases of systematic intelligence gathering, an undercover agent has to build (and betray) a very close, personal relationship with the suspect, whereas during infiltration, as the undercover agent often poses as a criminal entrepreneur, the relationship may be limited to a more 'professional' level (Kruisbergen, Kleemans et al., 2012: 405).

80 The BOB Act itself did not specifically forbid the use of criminal civilians in infiltration operations, but such a prohibition could be inferred from the legislative debate (Beijer et al, 2004: 277-278). 
of organized crime, and only if police officers and non-criminal civilians cannot be used, criminal civilians may be used in an infiltration operation (Tweede Kamer, 2012-2013, 29 911, no. 83: 4).

To ensure accountability, the BOB Act requires that a report is made of the methods of investigation used and that their deployment is accounted for at trial (Beijer et al, 2004: 277-278).

In addition to the legal conditions provided by the BOB Act, a public prosecutor has to comply with internal rules and procedures within the Public Prosecution Service ${ }^{81}$ Larger, more long-term criminal investigations targeting organized crime can only be started after a more or less centralized decision-making process, in which the targets of an investigation have been compared with general investigative priorities.

Once an investigation has started, a public prosecutor certainly is not completely autonomous. When he intends to deploy an undercover operation, he generally has to discuss this with a specialized investigative prosecutor and subsequently with the regional chief public prosecutor. ${ }^{82}$ In case of infiltration, the legally most far-reaching undercover power, a public prosecutor has to comply with further authorization requirements. In those cases, a prosecutor, after deliberation with the regional chief public prosecutor, has to submit a substantiated proposal to the Central Assessment Committee (in Dutch: Centrale Toetsingscommissie (CTC)). The CTC tests the proposed operation for proportionality and subsidiarity, among other factors. If the CTC considers the operation permissible, it puts the proposal to the Board of Procurators General, the highest level of authorization within the Public Prosecution Service. The board of Procurators General ultimately decides whether the infiltration operation is allowed or not. After the Board has given its approval, continuation of the infiltration operation requires the prosecutor to deliver feedback and to submit a plan for continuation on a three months' basis.

\subsection{Current study}

In the Netherlands, police agencies are relatively open to social science researchers. The Research and Documentation Centre (in Dutch: Wetenschappelijk Onderzoek- en Documentatiecentrum (WODC)) plays an important role in research on organized crime and criminal investigation. Because the WODC is part of the Ministry of Security and Justice, researchers of this institute have access to confidential data sources, such as police files (Van de Bunt, 2004: 678-679; De Poot, 2010; Marx, 1995: 329). Yet, in the Netherlands, too, empirical knowledge regarding undercover policing is scarce. One empirical study has

\footnotetext{
81 Under Dutch law, the authority over a criminal investigation lies with a public prosecutor.

82 At least when the research was conducted.
} 
been done on undercover policing in the Netherlands. However, Kruissink et al. (1999) conducted their research in the late 1990s, before the introduction of the BOB act. ${ }^{83}$

The data we use in this chapter cover all 23 Dutch criminal cases during the 2000-2005 period in which a proposal for an infiltration operation was submitted to the CTC. ${ }^{84}$ The data derive from a research project that was conducted by the WODC (Kruisbergen and De Jong, 2010).

For all of these 23 criminal investigations, we analysed the files of the CTC. When analysing these files, we made use of a checklist and collected information on (among other things) the grounds on which the public prosecutor wanted to deploy an infiltration operation and the decision of the CTC and the Board of Procurators General regarding the requested approval. Subsequently, for 19 cases we analysed the actual police files at the public prosecutor's offices. For three cases, none of which went to trial, these files could not be traced. With regard to one case the public prosecutor requested the exclusion of the police file. ${ }^{85}$ The police files include sources of information such as testimonies of undercover agents and reports of wiretaps, police observations and interrogations of offenders and witnesses. The files were analysed by means of a checklist that mainly focused on the strategy and tactics of the infiltration operation, the course and results of the operation, and the course and results of other investigative methods.

In addition, we conducted face-to-face interviews with 35 people, of which 20 were involved in the cases we studied. The other 15 respondents were selected on grounds of their direct or indirect involvement in other cases in which undercover operations were used. The respondents consisted of the (former) heads of the special police undercover units (8), detectives of the National Crime Squad (6), detectives of regional crime squads (5), public prosecutors (11), staff members of the CTC (2), a procurator general (1), and other specialist members of the police (1) and Public Prosecution Service (1). The interviews covered a range of topics (among other things): the kind of criminal cases and circumstances that are (not) feasible for deployment of an undercover operation; the planning, preparation and strategy of undercover operations; contacts between the undercover agent and the target; results of undercover operations; risks related to undercover operations; and the implementation of regulatory procedures.

83 Kruissink et al. gathered information on proposed undercover operations that were submitted for permission in 1996. Before the introduction of the BOB Act, the Dutch code of criminal procedure lacked specific sections that covered undercover policing. Kruissink et al. labelled every undercover operation in his research as 'infiltration', whereas undercover operations are divided into three different types since the BOB Act came into effect (see section 3.3).

${ }^{84}$ During the 2000-2005 period, authorization for an infiltration operation was requested in 24 Dutch criminal investigations. However, as in one case the infiltration operation was still ongoing at the time the rearch was conducted, that specific case was not included. Furthermore, the research only considers Dutch criminal investigations. Infiltration operations within the context of international legal assistance (for which approval was requested in seven cases during the 2000-2005 period) were not included.

85 Information on this case was gathered by conducting an interview with detectives who were involved in the investigation, and by analysing the CTC file. 


\subsection{Infiltration operations in the Netherlands}

In section 3.5.1, we will elaborate on the assessment of proposed infiltration operations by the CTC and the Board of Procurators General. Section 3.5.2 provides information about the grounds on which public prosecutors opt for an infiltration operation and the types of criminal offences that are targeted by these (proposed) operations. In section 3.5.3, we will look into the course and results of infiltration operations.

\subsubsection{The assessment of proposed infiltration operations by the Central Assessment Committee (CTC) and the Board of Procurators General}

During the 2000-2005 period, approval to deploy an infiltration operation was requested in 23 Dutch criminal investigations. In those cases, the public prosecutor submitted a substantiated proposal to the CTC. The CTC considered 16 of those 23 proposed operations permissible and subsequently brought those 16 proposals before the Board of Prosecutors General. In all those 16 cases, the Board followed the advice of the CTC and approved the deployment of infiltration.

In seven cases, the CTC assessed the use of an infiltration operation not admissible. For three of those cases (cases A1, B53 and B54) the reason for this negative decision lies in the fact that, according to the CTC, the undercover operation as described in the proposal should not be labelled as infiltration but rather as systematic intelligence gathering and/or (an) undercover buy(s). The fourth proposal (case B50) that was declined involved an operation targeting the sexual exploitation of minors. The operational goal of the infiltration operation came down to establishing contact with the subject and getting him to offer the sexual services of a minor. Although actual sexual activities were not to take place, the plan was judged to be ethically and politically unacceptable. A fifth and sixth proposal (cases B56 and B58) were declined because the CTC was of the opinion that, considering the course the criminal investigation was taking, it was too early to deploy an infiltration operation. In the seventh case (case B57), infiltration was not allowed since the CTC concluded that the case lacked sufficient suspicion of organized crime being committed or planned. 
Figure 1. Implementation and results of infiltration operation in The Netherlands, 2000$2005^{86}$

\section{Infiltration operation is proposed: $\mathbf{2 3}$}

\begin{tabular}{|c|c|}
\hline $\begin{array}{l}\text { Infiltration operation is } \\
\text { allowed: } 16\end{array}$ & $\begin{array}{l}\text { Infiltration operation is not } \\
\text { allowed: } 7\end{array}$ \\
\hline $\begin{array}{l}\text { Infiltration operation is } \\
\text { implemented: } 14\end{array}$ & $\begin{array}{l}\text { Infiltration operation is not } \\
\text { implemented: } \mathbf{2}\end{array}$ \\
\hline $\begin{array}{l}\text { Undercover agent makes } \\
\text { contact with target: } 13\end{array}$ & $\begin{array}{l}\text { Undercover agent makes } \\
\text { no contact with target: } 1\end{array}$ \\
\hline $\begin{array}{l}\text { Infiltration operation delivers } \\
\text { contribution to investigation } \\
\text { and/or trial: } 10 \\
\text { - evidence used for conviction of } \\
\text { suspect: } 6 \\
\text { - steering and/or rest information: } 4\end{array}$ & $\begin{array}{l}\text { Infiltration operation delivers no } \\
\text { contribution to investigation } \\
\text { and/or trial: } 4\end{array}$ \\
\hline
\end{tabular}

\subsubsection{In which cases and on what grounds does a public prosecutor opt for an infiltration operation?}

Of the 23 cases in which the public prosecutor proposed an infiltration operation, 17 involved drug trafficking investigations, four of which also targeted another criminal offence, such as illegal arms trade. The six remaining cases concerned investigations targeting terrorism (one), violence (one), illegal arms trade (one), child pornography (one), sexual abuse/exploitation (one) and human smuggling (one).

86 Year in which a proposal for an infiltration operation is submitted before the Central Assessment Committee (CTC). During the period 2000-2005 authorization for an infiltration operation was requested in 24 Dutch criminal investigations. However, as in one case the infiltration operation was still ongoing at the time the rearch was conducted, that specific case was not included. 
For 18 cases, the reason why the public prosecutor wanted to deploy an infiltration operation lay in the fact that other methods of investigation had proven (seventeen cases) or were assumed (one case) to be ineffective. This inadequacy of other policing methods particularly related to the high level of concealment maintained by the suspects; they frequently change cars, for instance, mainly have criminal meetings in person instead of 'doing business' by phone, and use concealed language. For five cases, it was impossible to point out one specific reason, for example because a combination of reasons was involved or the reason was unknown.

\subsubsection{Course and results of infiltration operations}

To determine the results, or success, of an infiltration operation, we assessed the contribution an operation has made to the investigation and/or trial. A first and most direct contribution is made when an infiltration operation generates evidence that is used to get a suspect convicted. Second, some operations may not generate evidence but do produce information that contributes in a more indirect manner. This may be steering information, i.e. information that played a part (in a minor of major way) in the course of the investigation, such as intelligence on the composition or activities of a criminal organization or information regarding the means of communication the criminals used. It may also be rest information, i.e. information, concerning suspects or criminal activities, that was not used in the investigation on behalf of which it was collected, but that was passed on to and used by another investigation team.

\section{Results}

Figure 1 summarizes the deployment and results of infiltration operations in the Netherlands during the 2000-2005 period. The course and results of infiltration operations will be exemplified with cases below.

In two of the sixteen cases in which an infiltration operation was approved, the operation was abandoned even before the start. In both cases the direct goals of the criminal investigation, the arrest and trial of the main suspects, were achieved by other policing methods prior to the start of the infiltration (see section 3.6.2).

Thus, during the 2000-2005 period, fourteen infiltration operations have actually been carried out in the Netherlands. In six cases the infiltration operation generated evidence, (partly) on the basis of which suspects were convicted. Five of these six operations not only contributed to the trial but also contributed, by producing steering information, to the investigation. For the other case this is unknown.

One of these six criminal investigations (B59), for example, focused on the production and trafficking of XTC. In this operation undercover agents had tens of contacts with the suspects, whether in person or by telephone. Meetings in person took place in catering establishments, among other places. The undercover agents and suspects engaged in leisure 
activities but only on a limited scale, since conversations soon turned to criminal activities. A first undercover buy was executed successfully. A second attempted 'deal' failed. A third undercover buy again succeeded when the suspects sold several hundreds of thousands of XTC pills, although this only amounted to slightly more than half the quantity that had been agreed upon. The two successfully completed undercover buys served as evidence, on the (partial) basis of which the main suspects, as well as other offenders, were convicted. Moreover, the infiltration operation yielded insight into the criminal activities of the main suspects.

In two other cases, the focus of criminal investigation shifted from the illegal arms trade to drug trafficking. In one of these cases (B43), the infiltration operation did produce some information regarding the illegal arms trade, but the storage location remained unknown and an attempt to buy weapons (undercover buy) failed. The undercover agents did succeed, however, in demonstrating the suspect's involvement in drug trafficking. Two undercover buys resulted in several kilos of heroin. An undercover buy involving a much larger quantity did not take place because the undercover agent and the suspect could not reach an agreed price. The earlier undercover buys as well as the undercover agents' statements served as evidence in the criminal trial against the main suspects.

Furthermore, in yet another case (B52), the criminal investigation targeted a group of people suspected of trafficking in precursor chemicals. Several undercover buys were executed in this operation. Yet, some of the samples of precursor chemicals bought by the undercover agent turned out to contain a fake substance. An intended undercover buy in which tens of litres of PMK (a precursor for the manufacture of XTC) would be acquired, eventually never took place because the suspects were unable to deliver. Nevertheless, the operation generated evidence. That evidence consisted of the undercover buys that did take place and statements made by undercover agents regarding their interaction with the suspects. Besides evidence, the operation also produced valuable steering information. As a result of the infiltration operation, an intermediary dealing in precursor chemicals was identified. Moreover, when the suspects and the undercover agent(s) had a meeting, the frequency of the telephone calls among the suspects increased as soon as the meeting was over. The taps on these telephone calls produced useful information (as well as evidence), but they also put the police on the track of a store for other illegal goods.

Four operations did not generate evidence but 'only' produced steering and/or rest information. Although these four operations did contribute to the investigation, their level of success, generally speaking, was lower than that of the six operations that yielded evidence. That is, for all infiltration operations that have been carried out, gathering evidence was one or the main objective - an objective that was not met in these four operations. 
One of these cases (B51) concerns a criminal investigation into an illegal arms trade. At first, the infiltration operation went very well. Earlier than expected, the undercover agent established a good contact with the main suspect. Despite these contacts, the main suspect was unable or unwilling to deliver weapons, as a result of which an intended undercover buy did not take place. Because of a lack of evidence, the investigation ended without any arrests, let alone convictions. Yet, the infiltration operation did produce information regarding (among other things): the specific criminal activities of an emerging ethnic group; and other criminal offences in which the main suspect appeared to be involved, which in part led to a new criminal investigation (rest information).

A criminal investigation into large-scale XTC trafficking provides another example (B42). In this investigation, the police deployed two separate infiltration operations. One of these targeted the main suspect, a very experienced and suspicious criminal. The second operation targeted one of the main suspect's fellow criminals. In the latter, an undercover agent got rather close with his target and became part of his social life, whereas the undercover agent who targeted the main suspect only established contact on a superficial level. The investigation's strategy included buying drugs from the main suspect. However, the intended undercover buys never took place, although negotiations were in an advanced state. Before those negotiations succeeded, several suspects were arrested, the main suspect among them. The arrests were a direct result of other methods of investigation (see section 3.6.2). These methods produced sufficient evidence to support the conviction of the main suspect as well as other suspects. The main suspect was convicted of trafficking many hundreds of thousands of XTC pills and leading a criminal organization, among other offences. The two infiltration operations did not produce any evidence. They did generate some information regarding the criminal organization, but it seems that this did not play a significant role in this or any other investigation.

Finally, four operations did not contribute to the investigation or trial at all. One of these cases was the only case in which the undercover agents entirely failed to penetrate their targets' social network; they could not make contact (B40). The criminal investigation ended without any arrests.

Another case concerned an investigation into terrorism in which the police found out that the suspect was trying to obtain weapons (B39). That information gave rise to a plan for a rather extraordinary infiltration operation; an undercover agent was to deliver weapons to the main suspect - who was to be arrested immediately after the delivery. ${ }^{87}$ The undercover agent and the suspect planned to meet each other to discuss conditions regarding the delivery. However, the suspect, who perhaps grew suspicious, did not show up. In spite of this lack of success of the infiltration operation - which did not contribute to the investigation or to the trial - several suspects were arrested and subsequently convicted.

87 The Dutch code of criminal procedure does not provide for an undercover sell. 
A third example clearly shows that even operations during which undercover buys are 'successfully' executed, may not contribute to the trial or criminal investigation (B48). The investigation targeted drug trafficking and focused on a main suspect who was supposed to be a key player 'behind the scenes'. This man proved very hard to make contact with. He had a very limited social life and only participated in criminal activity with people whom he knew well. Furthermore, according to a police report, he was fully aware of the fact that he might be under police surveillance. During the undercover operation, which ran for a very long time, undercover agents did establish good contact with people in the main suspect's entourage, but they met the man himself only once. The undercover agents even succeeded in buying tens of thousands of XTC pills. However, the drug deals could not be linked to the (supposed) 'key player' or other main suspects. These undercover buys as well as the infiltration operation and the criminal investigation as a whole, were closed without any arrests being made. Thus, the infiltration operation did not contribute to the trial, and since it did not produce any significant information, it did not contribute to the investigation either.

One of the reasons why some infiltration operations did not produce any results (four cases) or did not generate evidence (four cases), is the unpredictability of the interaction between the undercover agent(s) and the suspect(s), especially when it comes to undercover buys.

\subsection{Analysis: unpredictability and regulation of undercover operations}

In this section we will look more in depth into the investigative practice of infiltration operations in the Netherlands. Section 3.6.1 explores a characterizing feature that emerges from the empirical data on infiltration operations; the unpredictability of the meetings between the undercover agent and the suspect. The fundamental unpredictability of criminal investigations targeting organized crime has consequences for the practical implementation of (some) regulatory procedures. The implementation of regulatory procedures is the subject of section 3.6.2.

\subsubsection{Unpredictability, the consequence of participating in illegal markets}

An undercover agent, as mentioned in section 3.2.1, has to penetrate an offender's social network. In infiltration operations deployed against criminals who are trafficking in illegal goods, this often means that an undercover agent poses as a criminal entrepreneur, a drug dealer for instance, who is interested in doing business. The purpose of such an operation is to display (suggest) enough capability and trustworthiness to allow the suspect to think that it is profitable and safe to make his 'fellow criminal' an offer to buy drugs. However, since the undercover agent poses as a criminal entrepreneur, he is confronted with the unpredictable behaviour common to illegal markets. 
In chapter 2, we described the unpredictable course of undercover operations, especially those focusing on bringing about one or more undercover buys. That chapter focused on all undercover operations in the Netherlands executed in one year, 2004. In that specific year all undercover operations consisted of the undercover powers of systematic intelligence gathering and/or undercover buys. Infiltration was not used in 2004. The course of (intended) undercover buys that are part of infiltration operations proves to be even more erratic than the 2004 cases. In the 2000-2005 period, infiltration was used in fourteen criminal investigations. In one of these operations, the undercover agent did not establish contact with the target. Of the remaining thirteen operations, twelve focused on bringing about one or more undercover buys, among other things. Of these twelve operations, none worked out as planned.

Some undercover buys do not take place at all. One reason may be that an undercover agent, although he did make contact with the initial subject, failed to establish sufficient contact with the key player within a criminal organization. Case B47 provides an example. In this case, undercover agents made contact with several members of a criminal organization (allegedly) involved in cocaine trafficking and money laundering. On several occasions an undercover agent travelled abroad to meet the 'big man'. Yet, although they met several family members of the 'big man', in the end the key player himself never showed up. That is presumably the reason why the undercover agents never effectuated an actual drug deal (undercover buy), even though suspects promised they could deliver hundreds of kilos and discussed details and prices. The reason why the 'big man' never showed up is unknown. Perhaps, in the end, the undercover agents were not deemed capable and/or trustworthy enough. The reason, however, might also have little to do with the undercover agents' performance. As is clear from other examples, it is not easy to 'do business' with criminals efficiently; often commitments are not kept and/or expectations are not met.

Another reason why undercover buys do not take place may be that the suspect(s) is (are) unable to deliver. One example concerns an investigation into the illegal arms trade (B43). An undercover agent established contact with the suspects, who were found willing to do business. However, since their supplier in Eastern Europe had been arrested, they could not keep their promise to deliver a large quantity of weapons. During a conversation, one of the suspects offered several automatic weapons to be delivered that same evening. When later on the suspect could not be reached by the undercover agent, the suspect explained this on a later occasion by saying he was 'hot' (under police surveillance). Case B51 also concerned the illegal arms trade. In this case, undercover agents managed to establish a good contact with the main suspect relatively quickly. However, the main suspect turned out to be incapable of or unwilling to sell weapons, which was a possible consequence of (perceived) intensified security measures in the aftermath of $9 / 11$.

In some cases, a suspect turns out to be unable to deliver simply because he lacks the required resources or capability to live up to his promises. Still another reason is 
cautiousness on behalf of a suspect to do business with people he has met only recently. In these cases the suspect's unwillingness may also be caused by the fact that the undercover agent does not play his role convincingly enough. Finally, the undercover agent himself may cancel an undercover buy. In case B41, for example, an undercover agent cancelled a deal on tens of thousands of XTC pills because he had reason to believe that the delivery would probably originate from offenders outside their scope of interest.

Other undercover buys do take place but do not work out as planned. In some cases the goods that are bought from a suspect may not be what the undercover agent thought they would be, like in case B52, where samples of 'precursor chemicals' proved to contain a fake substance. Case B46 concerned a criminal investigation into child pornography. An undercover agent managed to buy several CD-ROMs from a suspect. Although the CDROMs did contain pictures, they did not contain child pornography.

Cases B43 (see section 3.5.3) and B49 provide examples of investigations that initially focused on the illegal arms trade but, after an attempt to buy weapons failed, switched to drug trafficking when drug deliveries did prove to be possible. Sometimes an undercover buy does not live up to initial expectations in another sense, like when, for instance, tens of thousands of XTC pills were bought, but the deliveries could not be linked to the main suspects (B48).

In several cases, an undercover buy took place, but only after earlier intended undercover buys failed. Furthermore, in some cases the quantity of delivered goods turned out to be (much) smaller than agreed, like in case B59 (see section 3.5.3).

The fact that an undercover operation does not work out as planned, does not automatically mean that the operation does not contribute to the investigation and/or trial. However, in general, unexpected developments such as described above do cause undercover operations to last longer or remain without the intended results.

\subsubsection{Implementation of regulatory procedures in the investigative practice}

Since the BOB Act came into effect, (most) methods of criminal investigation are covered by specific sections in the code of criminal procedure. Besides filling the legal vacuum, the BOB Act certainly has improved transparency of the use of methods of investigation. The $\mathrm{BOB}$ Act requires that a report is made of the methods of investigation used. Furthermore, when the police use a special investigative police power, its deployment, in principle, will be accounted for at trial (Beijer et al, 2004: 277-278). Before the introduction of the BOB Act, judges often were not even informed about the simple fact that an undercover operation had been deployed (Van Traa, 1997: 16). An evaluation of the BOB Act showed that Dutch judges have gained more insight into the deployment of special methods of criminal investigation (Beijer et al., 2004: 282). The importance of transparency and accountability in court, and the fact that judges seem satisfied with the reporting of and 
insight given into the use of investigative methods, also shows when examining court decisions regarding undercover operations (see chapter 2).

However, as the following subsections will show, regulatory requirements not always entirely work out as planned.

\section{Testing for subsidiarity}

How meetings between an undercover agent and a suspect will work out is very unpredictable, as was shown in section 3.6.1. However, it is not the undercover operation alone that 'suffers' from this unpredictability. Because of the relative large number of suspects in an average organized crime investigation, the erratic behaviour of these suspects, and the fact that different policing methods are usually deployed simultaneously, investigating a phenomenon such as organized crime is unpredictable in itself. Because of this fundamental unpredictability, authorization procedures may not always fit the investigative practice. For one thing, it makes it harder to test prospectively for subsidiarity.

In most cases, the reason why a public prosecutor wants to deploy infiltration lies in the fact that other methods of investigation have proven to be ineffective (section 3.5.2). When testing a proposed infiltration operation for subsidiarity, the CTC and the Board of Prosecutors General have to judge whether it is likely that the goals of the criminal investigation can be achieved by deploying other policing methods. This test has a retrospective, as well as a prospective, element. The retrospective judgement encompasses the policing methods that already have been used in a criminal investigation. The prospective judgement means assessing the probability that other methods than infiltration will produce any decisive results in the weeks and months to come.

In several cases in which the Board of Prosecutors General authorized an infiltration operation, it turned out that other methods of investigation did in fact generate decisive results, although they were deemed ineffective.

Two of these cases concerned investigations into the production/trafficking of synthetic drugs. According to the proposal for infiltration, in case B45 other methods of investigation did generate sufficient information regarding the production of XTC, but they failed to produce results in determining who was responsible for exporting the drugs. In order to fill this gap, the public prosecutor proposed infiltration, and the proposal was subsequently authorized by the Board of Prosecutors General. Yet, before the infiltration unit started its operation, wiretapping, among other methods, did reveal which players were involved in exporting the XTC. Ultimately, several suspects were convicted, the main suspects included, mainly on the grounds of information generated by wiretapping, bugging (face-to-face conversations) and statements. Case B55 showed a similar course of events. In this case, the investigation team was unable to gather evidence regarding the production of XTC and could not locate the XTC lab. Yet, only a few days after the infiltration operation was approved, the two main suspects, i.e. the owner of the XTC lab and the chemical technician, were arrested. Both 
were convicted. Here also, the evidence was collected by means of wiretapping, bugging and statements, among other methods.

In three other cases, the infiltration operation was executed, but the convictions that followed in these cases were achieved without any major contribution from the undercover operation. One of these cases concerned an investigation targeting cannabis trafficking (B44). Although several special investigative methods were used, the investigation team failed to gather concrete evidence against the main suspects. The public prosecutor therefore proposed an infiltration operation. The plan was approved. Several undercover agents were deployed in this operation and they managed to make contact with the main suspect as well as with people in his entourage. Part of the operation's strategy was to perform an undercover buy. Yet, an undercover buy never took place, since other methods of investigation produced sufficient evidence to arrest and subsequently convict several suspects. These other methods of investigation were, among others: wiretapping, observation (visual surveillance), bugging, and a house search. ${ }^{88}$

Case B42 concerned the aforementioned criminal investigation into large-scale XTC trafficking (section 3.5.3). Here also, infiltration was proposed because other policing methods did not generate decisive results. Furthermore, as the proposal mentioned, the investigation targeted a highly experienced criminal who acted very cautiously and was fully aware of possible police attention. He used concealed language when talking on the phone, used different pre-paid cell phones, adjusted his driving behaviour to render surveillance more difficult, and travelled under a false name. As the results of wiretapping clearly showed, however, other suspects were certainly not as disciplined as the main suspect was. Some of those other suspects, for instance, relatively openly discussed with each other their frustrations about the main suspect's behaviour towards them. The infiltration operations did not generate any evidence, nor did they produce any information that played a significant role in this or any other investigation. Sufficient evidence to arrest and subsequently convict several suspects, the main suspect included, was produced by other methods of investigation. Those other methods were bugging, wiretapping, statements made by suspects and witnesses, observations, covertly entering the suspect's premises (in Dutch: 'inkijkoperatie'), and using a surveillance beacon. ${ }^{89}$

When testing prospectively for subsidiarity, the CTC and the Board of Prosecutors General have to assess the likely development of a criminal investigation. The aforementioned cases show that this procedure presupposes a level of predictability that contradicts the complex and unpredictable nature of investigations into organized crime.

88 The infiltration operation did in fact produce relevant information. Thanks to the operation, a formerly unknown member of the criminal collaboration came into the picture. For tactical reasons, however, this information was not used in this case and was passed on as rest information. It actually led to police activity targeting this specific suspect, but the results of these activities are unknown.

89 Finally, an investigation into terrorism led to the arrest and conviction of the main suspect without any contribution being made by the infiltration operation that was deployed (case B39, see section 3.5.3). 


\section{Unintended effects of authorization procedures: 'interference aversion'}

If a public prosecutor wants to deploy an infiltration operation, he has to comply with several authorization requirements (as described earlier in section 3.3.2). Ultimately, he has to get approval of the highest level of authorization within the Public Prosecution Service, the Board of Prosecutors General. When a proposed infiltration operation is approved, a public prosecutor has to obtain renewed approval of the Board of Prosecutors General on a regular basis.

In the investigative practice, this centralized decision-making process may produce unintended effects. Some public prosecutors may fear that they will lose control if they choose to use infiltration, and therefore might avoid this investigative method.

A head of an undercover police unit phrases it as follows:

'That is disadvantageous to opting for an infiltration operation in an early stage. You will have to deal with the interference of the Board of Prosecutors General.'

As two members of the Central Assessment Committee (CTC) mention:

'We notice that public prosecutors want to avoid having to put a substantiated proposal before the CTC. They don't appreciate the interference. As soon as a public prosecutor has to deal with the CTC, his operation is forced into a 'straitjacket' of periodic review'.

This fear of losing control, or 'interference aversion', may constitute one of the reasons why undercover operations, especially infiltration, are so scarcely used in the Netherlands; during the 2000-2005 period, infiltration was proposed in 23 Dutch criminal investigations, 16 of which were approved, and 14 of which were actually executed. ${ }^{90}$

Earlier research among public prosecutors (and police officials) has shown that, besides avoidance of undercover operations, interference aversion may produce another outcome as well (Beijer et al., 2004: 109). When deploying an undercover operation, different undercover powers, such as systematic intelligence gathering and undercover buys, may be combined in one operation. For a public prosecutor, it might not always be clear which (combination of) undercover power(s), i.e. which legal label, is applicable to an intended undercover operation. Yet, the difference with regard to authorization requirements is very clear; infiltration requires the highest level of authorization, whereas systematic intelligence gathering and undercover buys do not. Therefore, in cases in which public prosecutors doubt whether an intended undercover operation should be labelled as

90 In the years 2006, 2007 and 2008, according to the Annual Report 2008 of the CTC, infiltration was proposed in one, two and one cases, respectively (CTC, 2009: 13). These numbers may include proposals within the context of international legal assistance. 
infiltration or as a combination of systematic intelligence gathering and undercover buys, some may be inclined to choose the latter.

\subsection{Discussion}

In this chapter, we have provided empirical insight into the deployment and results of infiltration operations in the Netherlands. Moreover, we have looked into some outcomes of regulatory procedures with regard to infiltration operations. We will summarize the most important findings and discuss some implications.

First, in the 2000-2005 period, the Board of Prosecutors General authorized the use of deployment in sixteen cases, fourteen of which were actually deployed. In six cases the infiltration operation contributed to the trial, i.e. it produced evidence on the (partial) basis of which suspects were convicted. Four operations 'only' produced steering and/or rest information, while four operations did not contribute to the investigation or trial at all.

Second, the research showed that the course of infiltration operations is very unpredictable. This unpredictability especially holds for operations that include (intended) undercover buys. In those operations, an undercover agent often poses as a fellow criminal who may want to do 'business'. Thus, he participates in a criminal market and is therefore confronted with the unreliability and unpredictability that is so typical of criminal markets. Of the thirteen infiltration operations in which the undercover agent(s) established contact, twelve operations involved one or more (intended) undercover buys. None of these twelve operations worked out as planned.

Third, the empirical results provided insight into the implementation of regulatory procedures in the investigative practice. A criminal investigation, especially when it focuses on organized crime and perhaps even more so when it involves undercover operations, is a very complex, 'unruly' process (cf. Neyroud and Disley, 2007: 553). The potential invasiveness of policing methods justifies attempts to rationalize and control this process. Criminal investigations are, in fact, increasingly subjected to laws and procedures. As we saw in section 3.6.2, the introduction of the BOB Act certainly improved transparency, and therefore the accountability, of the use of investigative instruments in criminal cases. However, laws and authorization procedures may not always completely work out as planned. The intention to restrict the use of invasive policing methods (or methods that are regarded as such) to cases that really require their deployment, is rational and legitimate. Yet, testing prospectively for subsidiarity clashes to a certain extent with the fundamental unpredictability that characterizes investigations into organized crime. Likewise, centralized authorization procedures intend to assure a well-considered use of potentially risky methods of investigation. Yet, they may also produce 'interference aversion' and thereby result in unwanted outcomes.

As we saw, criminal investigation is a relatively neglected field of research for criminologists (Grabosky, 2010: 364; see also De Poot, 2010: 102). In part, this may be 
the consequence of the choices made by criminologists. It is also caused, however, by the reluctance of authorities to open up to social scientists or to provide information on police activities, such as the number, let alone the types and results, of undercover operations. Especially in Europe, there is very little empirical knowledge on undercover policing. Therefore, even the 'leading police scholars in Europe (...) are generally forced to rely on the occasional government report of a scandal, court records, historical and mass media accounts, and their experience as citizens' (Marx, 1995: 329).

Because of the sensitive nature of policing, let alone policing methods that are deployed against organized crime, the investigative process can never be fully transparent (Walsh and Conway, 2011: 71). It is very well feasible, however, to conduct research on investigative methods without jeopardizing any specific criminal investigation or disclosing operational tactics. It is not only feasible, but it might also be very useful and even necessary. As Bean - when referring to informers and witness protection schemes - puts it: no strategy should remain so secretive as to remain without critical evaluation (Bean, 2001:161; Fyfe and Sheptycki, 2006: 350-351). Besides filling the existing scientific, criminological gap, empirical research on methods of criminal investigation may serve three goals.

First, a greater knowledge base may help the Public Prosecution Service to exercise the authority in criminal investigations.

Second, a greater transparency of investigative practice may serve the legislative debate. Methods of investigation that are used against organized crime were and still are the subject of, sometimes heated, debate. Debates regarding the invasiveness, necessity and risks of methods of investigation, can be improved when information is available on the number and kind of cases in which these methods are deployed and on the results they produce.

Third, empirical insight into the practical outcomes of formal, regulatory requirements may serve to improve regulatory quality (cf. Ayling, 2013: 15). 


\section{Profitability, power, or proximity? Organized crime offenders investing their money in legal economy}

This chapter uses empirical data from the Dutch Organized Crime Monitor to give empirical insight into the choices organized crime offenders make when they invest their money in legal economy. ${ }^{11}$ Using a dataset of 1,196 individual investments, light is shed on what kind of assets offenders purchase and where these assets are located. The results are used to assess the tenability of different theoretical perspectives and assumptions that are present in the literature on money laundering and organized crime: the standard economic approach ('profit'), the criminal infiltration approach ('power') and social opportunity structure ('proximity'). The results of this study show that offenders predominantly invest in their country of origin or in their country of residence and that their investments consist of tangible, familiar assets such as residences and other real estate and (small) companies from well-known sectors. Investments such as bonds, options, and stocks in companies in which offenders are not personally (or indirectly) involved, such as stocks in companies noted on the stock exchange, were only found in a small number of cases. In other words: offenders usually stay close to home with their investments. So, instead of profitability or power, proximity seems to be a better description of their investment choices.

A slightly different version of this chapter was earlier published as: Kruisbergen E.W., Kleemans E.R. and Kouwenberg R.F. (2015). Profitability, power, or proximity? Organized crime offenders investing their money in legal economy. European Journal on Criminal Policy and Research, 21(2): 237-256. 


\subsection{Introduction}

Organized crime aims at generating financial gain. ${ }^{92}$ Criminal earnings may be reinvested in criminal activities, they can be consumed to sustain a certain lifestyle, and, insofar necessary expenditures permit, an offender might also invest in the licit economy.

One of the greatest dangers of organized crime is often believed to be the capability of criminal groups to infiltrate in the economy and in the licit society at large (e.g. Barone and Masciandaro, 2011: 116; Europol, 2006; see also Verhage, 2009, 2011; Naylor, 2002: 34). The perceived threat of criminals earning and spending huge sums of money and gaining influence in economic, social and political spheres, was - and still is - an important driving force behind anti-money laundering measures (see for a review, e.g. Levi and Reuter, 2009). It was one of the reasons to build up an anti-money laundering system during the 'war on drugs' in the 1980s and 1990s, which, more recently, was intensified by the 'war on terror'. Although both 'wars' were proclaimed by the United States, today in many countries all over the world anti-money laundering and asset forfeiture legislation has (long) come into effect and judicial authorities are getting more and more involved in financial investigation. These efforts are not only directed at drug crimes and terrorism, but at all sorts of criminal activity (Levi, 2002: 183-186; Van der Schoot, 2006; Reuter and Truman, 2005; Gelemerova, 2011).

Despite an impressive range of anti-money laundering measures and a body of literature on this subject, empirical research is relatively scarce (see the following section). The purpose of this chapter is to contribute to the empirical evidence on money laundering. From an offender's point of view, the ultimate purpose of money laundering is the ability to use the profits of crime. Therefore, instead of looking into money laundering techniques, such as a loan back scheme for example, we will focus on how offenders actually spend their money. Our main point of interest concerns investments in the legal economy, since these kinds of investments seem to be the most important reason for concern. The data we use consist of 150 cases from the Dutch Organized Crime Monitor (see section 4.3). Examining these cases regarding financial information, we were able to construct a dataset of almost 1,200 individual assets.

We address the following research questions: 1) What do offenders in organized crime invest their money in? 2) Where do they invest their money? and 3) What can be inferred from offenders' investments about underlying strategies and motives? In the following section we look into the existing literature and explore theoretical perspectives on investment behaviour of organized crime offenders. The data we use are described in section 4.3. In section 4.4 we present empirical insight into the investments of organized

92 Besides money there might be other motivating factors promoting participation in organized crime, such as an offender's preference for an exciting life, the desire to impress peers, or, especially with regard to 'Mafia-type' organized crime, the exercise of power (Naylor, 1999: 11). 
crime offenders in the legal economy. In section 4.5 we summarize the empirical results and we use those results to assess the tenability of different theoretical perspectives.

\subsection{Theoretical perspectives and empirical research}

\subsubsection{Theoretical perspectives}

Whatever a criminal does with illegal proceeds, it is safe to assume that he wants to avoid confiscation or arrest by the authorities. Given this basic limitation, offenders still have choices to make in their investment portfolio. Existing literature provides us with theoretical notions and assumptions on possible strategies or motives underlying the choices offenders make when investing their money. Two theoretical perspectives that can be found in the literature on (anti-) money laundering are the standard economic approach and the criminal infiltration approach.

With regard to the driving forces that are supposed to determine the investment strategies of offenders, the standard economic approach may be summarized as profitability. It stresses the similarity between participants in organized crime and licit entrepreneurs and it assumes that criminal 'entrepreneurs' make cost/benefit efficient investments in a globalized economy. Comparing criminal collaborations with multinationals, D'Andria, for example, points to shared 'management practices': 'Recent transformations affecting large criminal organisations worldwide point to a mutation towards high internationalisation and management practices similar to incorporated enterprises' (D'Andria, 2011: 1). A similar assumption can be found in Shelley (2006: 43).

Besides assuming a cost/benefit focused criminal actor (see also Masciandaro et al., 2007), some authors who apply the standard economic approach elaborate assumptions regarding the highly flexible investment behaviour of organized crime. Offenders or criminal organizations are supposed to be very flexible when it comes to switching between countries or economic sectors. Investment choices are supposed to be mainly defined by expected returns and/or costs of an investment in a specific sector or country. ${ }^{93}$ The costs, in turn, are defined by (amongst others) law enforcement activity (anti-money laundering regulations, police activity) applying to a specific sector or country; strict supervision on transactions make it more difficult - expensive - to safely spend dirty money. Furthermore, some authors assume transaction costs to be non-existent. So, when the cost/benefit analysis for sector or country B produces better results than the cost/benefit analysis for sector or country A, criminal organizations will withdraw their investments from A and turn to B (D’Andria, 2011: 6-10; Barone and Masciandaro, 2011: 136).

D'Andria does include non-monetary variables when he discusses reasons that bring a person to 'join' a criminal organization (D'Andria, 2011: 3-4). 
The criminal infiltration approach was an important impetus in the development of the anti-money laundering system. In terms of the motivation behind - or the consequences of - the investment choices offenders make, it can be summarized as power; organized crime offenders gain power and influence by investing in the legal economy.

A clear example is present in documents of the Financial Action Task Force (FATF): 'Organised crime can infiltrate financial institutions, acquire control of large sectors of the economy through investment, or offer bribes to public officials and indeed governments. The economic and political influence of criminal organisations can weaken the social fabric, collective ethical standards, and ultimately the democratic institutions of society' (FATF, 1999: 3; FATF, 2014). Murray, although less distinct, states: 'money laundering [...] is the key crime enabling organised crime groups to develop their influence in our democracies' (Murray, 2013: 99). ${ }^{94}$

\subsubsection{Empirical research}

Literature on money laundering might be classified into three groups. First, several studies tried to assess the size of financial flows involved in money laundering, resulting in a wide range of estimations (Schneider, 2010; Barone and Masciandaro, 2011: 116-118; Malm and Bichler, 2013). These estimations have been criticized for being nothing more than 'speculative guesstimates' (Levi, 2012: 610; see also Naylor, 2003: 262-263). Despite this criticism, some of these estimates are frequently cited and have become 'facts by repetition' (Levi and Reuter, 2009: 362)..$^{95}$

A second category of articles and books focuses on responses to money laundering. There is an abundance of publications in which policy measures against money laundering are reviewed (Levi and Reuter, 2009: 359).

The third category consists of empirical research on how offenders actually spend their money and try to conceal its criminal background. According to several authors, empirical research is scarce, particularly concerning large scale offenders, in fraud for example (Malm and Bichler, 2013; Van Duyne and Levi, 2005 ; Levi and Reuter, 2009: 359; Suendorf, 2001: 9; Verhage, 2011: 172; Van Duyne, 2003: 68-69; Fernández Steinko, 2012: 909; Levi, 2012).

For this chapter, we conducted a literature search for empirical studies on money laundering, or more specifically the investment behaviour of offenders. Several empirical studies were found, covering various countries. So empirical research on the investments of offenders certainly exists. However, if we compare it with the body of literature on

\footnotetext{
94 Elements of these two perspectives are sometimes used next to each other.

95 Frequently cited estimations of the size of money laundering on a global or international scale, are those produced by Michel Camdessus, Managing Director of the IMF (1998, in UNODC, 2011: 19), and Walker (1999). The most well-known estimations of money laundering in the Netherlands were produced by Unger (Unger, 2008; Unger et al., 2006).
} 
anti-money laundering regulation, it is indeed relatively scarce. Furthermore, some of the studies focus on only one particular type of crime and/or do not provide any or only limited insight into foreign investments. Since some studies seem to go unnoticed, we briefly describe the major studies below. ${ }^{96}$

In the Netherlands Meloen et al. conducted a study on 52 cases that each had an estimated sum of criminal earnings of at least $€ 450,000$ (Meloen et al., 2003). They used police files to gather information on several aspects of offenders' investments in the Netherlands as well as in foreign countries. Van Duyne used the same data in several publications (e.g. Van Duyne, 2003; Van Duyne and Levi, 2005). Van Duyne also analysed the Dutch asset seizure database of the Public Prosecution Office and the Central Recovery Office, focussing on real estate and criminal funds, in the Netherlands as well as in foreign countries (Van Duyne, 2013; Van Duyne and Soudijn, 2010). Furthermore, the Dutch police publishes research reports on money laundering in which statistics, interviews and case files are analysed (Soudijn and Akse, 2012). Schneider (2004) analysed the files of 149 Canadian proceeds of crime cases from the 1990s. Three quarters of his cases consisted of drug cases. Schneider did not look into foreign investments, except for the use of foreign banks. Malm and Bichler (2013) also used Canadian data. They applied social network analysis to a dataset of 916 suspected members of organized crime networks who were known to participate in drug markets. Their dataset was based on intelligence instead of criminal cases. They did not look into foreign investments.

The investment behaviour of the Italian Mafia was studied by researchers working at research centre Transcrime (e.g. Riccardi, 2014; Transcrime, 2013). They used data on confiscated goods and mainly focused on assets in Italy.

In Spain, Fernández Steinko (2012) analysed the documents of 367 court cases, more than $90 \%$ of which were drug cases. He presented information on several types of assets and also addressed financial flows to foreign countries.

Suendorf (2001) carried out a study on German offenders. He interviewed 89 experts and evaluated 18 files that were selected by those experts. His study also presents results on investments of immigrants in foreign countries.

Petrunov (2011) wrote an article on money management in cases of human trafficking. He conducted interviews with Bulgarian traffickers and prostitutes, among others. Petrunov mainly distinguishes between investments in Bulgaria on the one hand and investments in destination countries on the other.

Finally, two studies were conducted based on interviews with imprisoned offenders in the United Kingdom. The Matrix Knowledge Group (2007) interviewed 222 prisoners convicted for drug crimes. The study only briefly addresses the assets of those convicts and does not look into foreign assets. Webb and Burrows (2009) used interviews with 45

96 We do not claim this review to be exhaustive. 
prisoners convicted for human smuggling or human trafficking offences. Their study does pay attention to investments in foreign countries.

In section 4.4 we will compare our own empirical results with the main results of the studies mentioned above. ${ }^{97}$

\subsection{Methodology}

\subsubsection{Definition}

In this chapter we focus on investments in legal economy, such as real estate objects, companies, bonds, and options, leaving aside investments in criminal activity as well as any form of consumption, such as spending money on nightlife, clothing, cars, boats, and jewellery. ${ }^{98}{ }^{99}$ Cash money and deposits are also not included in our analyses. We do not consider keeping money in cash as an 'investment'. Furthermore, if we would include cash money and deposits, as a consequence, some 'investments' would be entered twice in our dataset. This would be the case if, for example, a case report holds information indicating that an offender has smuggled cash (or put money in a bank account) to a foreign country to buy a house. In such a case the house is entered in our dataset as a real estate object; also entering the cash would result in a double entry.

\subsubsection{Data and methods}

The empirical data we use consist of a dataset of 1,196 individual assets of (suspected) participants in organized crime. This dataset covers various crimes, such as different sorts of drug trafficking/production, human smuggling, human trafficking and illegal arms trade, but also (large scale) fraud and money laundering. Furthermore, the dataset includes information on foreign assets. To build this dataset, we used all 150 cases that were analysed in the Dutch Organized Crime Monitor.

The Dutch Organized Crime Monitor is an ongoing research project. The main sources of information are closed Dutch criminal investigations into criminal groups. In four data sweeps, during the period 1996-2011, this resulted in 150 case reports. As each case focuses on a criminal network, together the 150 case reports contain information on many hundreds of suspects.

In the Dutch Organized Crime Monitor case studies are selected following a survey

${ }_{97}$ By the time this study is published, the following research projects should have published results: Organised Crime Portfolio (http://www.ocportfolio.eu), Assessing the Risk of the Infiltration of Organized Crime in EU Member states Legitimate Economies (http://arielproject.eu), and Financing of organized crime activities (FINOCA).

98 We focus on investments in the legal economy because these kinds of investments seem to be the most important reason for concern among policymakers (see section 4.1).

99 Some might argue that jewellery, such as an expensive watch, could be considered as an investment. In this chapter, however, they are viewed as consumption goods. 
of criminal investigations of the police force and special investigative policing units. The case studies are not selected randomly. In organized crime research, a random sample is inconceivable, as police priorities - highlighting certain criminal activities and certain suspects - provide the basis for any sample researchers should want to construct. We therefore opted for a strategic sample that incorporates the heterogeneity of criminal activities and offenders (see for more information: Kleemans, 2007). Richness of information is an important selection criterion and we avoid focusing solely on, for example, drug trafficking. Some types of organized crime are 'oversampled' on purpose, because they add more knowledge to what we already know (Van Koppen, 2013b: 11). ${ }^{100}$

A case study starts with an interview with a police officer and/or public prosecutor. Subsequently the police files are analysed and a case report is written, using an extensive checklist. ${ }^{101}$ The police files contain the results of all police activities that were deployed in a case, such as wiretapping, observation techniques, undercover policing, gathering intelligence, interrogations of suspects, victims and witnesses, the confiscation of goods, and financial investigation.

To build our dataset, we checked every case report for available information on offenders' assets. ${ }^{102}$ This resulted in 1,196 individual assets, which were entered in SPSS. We used every source of information available in the case reports, i.e. we did not only look for confiscated assets but also used, among other sources, statements of suspects and witnesses, intelligence from informers, seized bookkeeping and records, and monitored telephone conversations.

Due to the empirical richness of the data, the Dutch Organized Crime Monitor is a unique research project (Paoli and Fijnaut, 2004c: 606). In this specific case, the monitor enabled us to build a dataset that is one of the few that, for various crimes, contains empirical information on organized crime offenders' assets in the Netherlands as well as in foreign countries.

\subsection{Results: investments of organized crime}

Due to the illegal nature of his business, a participant in organized crime is confronted with certain risks. As a criminal 'entrepreneur', he operates in an unregulated environment. His business is always in danger of sudden termination as a consequence of seizures or arrests, and his colleagues may prove to be untrustworthy (cf. Reuter, 1983: 113-17; Naylor, 2002:

100 It is important to note that the investment behaviour of offenders was not a selection criterion.

101 The checklist elaborates upon: the composition of the group and how offenders cooperate; the illegal activities they participate in and the methods they use; the interaction with the licit as well as the criminal environment; the criminal earnings and the way these earnings are spent; the criminal investigation itself; the criminal court case; and opportunities for prevention (Van Koppen et al., 2010: 108; Kleemans and De Poot, 2008: 70; for more information, see: Kruisbergen, Van de Bunt et al., 2012; Kleemans, 2007). 
21; see also chapter 2). Because of these risks, according to Naylor, offenders do not use their profits to invest but rather spend their money on an extravagant life style, thereby enhancing their prestige among peers (Naylor, 2002: 20-21).

The 150 cases in the Dutch Organized Crime Monitor indeed present plenty examples of offenders with an exuberant consumption pattern. Conspicuous spending by offenders is mentioned by various other authors as well (e.g. Levi, 2012: 610; Fernández Steinko, 2012; Matrix Knowledge Group, 2007; Van Duyne, 2003: 87). However, an exuberant consumption pattern does not preclude the possibility of investment. In various cases spending money on expensive cars, boats, jewellery, holidays, and girlfriends, is combined with investments in real estate and legal firms. In those cases, criminal earnings simply are large enough to facilitate both (Kleemans et al., 2002: 131). In the rest of this section, we elaborate on the investments we encountered in the cases provided by the Dutch Organized Crime Monitor.

\subsubsection{Investments: property and companies}

For 124 of the 150 cases in the Dutch Organized Crime Monitor, information was available on investments in real estate objects and/or companies in the Netherlands or another country. These 124 cases account for a total of 1,196 individual assets. Table 1 gives a brief overview. ${ }^{103}$ The total number of property objects and companies per case varies from 1 to 117 . Within the 124 cases in which information on this kind of assets was found, the average number of assets is 9.7 , whereas the median is 5.0. The distribution is very skewed, as can be seen by the difference between both measures of central tendency. ${ }^{104}$ Although in $90 \%$ of the 124 cases the number of assets is less than (or equal to) 16, in some cases of fraud or money laundering the number of assets is much higher. Although only a quarter of the 124 cases fall within the category 'fraud or money laundering' as main criminal activity, they account for almost half of the 1,196 assets that were found in all 124 cases. In this category of cases we find a small number of 'businessmen' with very large investment portfolios. Or as Van Duyne and De Miranda put it: 'few move much and many move only few' (Van Duyne and De Miranda, 1999: 257; see also Fernández Steinko, 2012: 919). In following analyses we will distinguish - if necessary - between cases of drug trafficking, human smuggling, human trafficking, and illegal arms trade (and other offences) on the one hand, and cases of fraud and money laundering on the other hand. ${ }^{105}$

103 Other investments will be discussed in section 4.4.2.

104 If a distribution is skewed, the median is more informative than the mean since the former is less sensitive to extreme values than the latter.

105 In one case the category of criminal activity was changed from 'other' (extortion) into 'money laundering'. The main suspect in this case was involved in extortion. However, almost all of the tens of assets that were found in this case belonged to another offender. Since this specific offender mainly participated as a money launderer, the case was coded as a money laundering case. 
Table 1. Investments of organized crime offenders in real estate objects and companies: number of cases in which assets occur and total number of assets

\begin{tabular}{lll}
\hline & ${\text { Cases } \%(\mathbf{N})^{\mathrm{a}}}$ & Total number of assets $^{\mathrm{b}}$ \\
\hline Property & $58.0 \%(87)$ & 447 \\
Companies & $75.3 \%(113)$ & 892 \\
Property and/or companies & $82.7 \%(124)$ & 1,196 \\
No known assets/not enough information & $17.3 \%(26)$ & 1,196 \\
\hline
\end{tabular}

${ }^{a}$ Categories are not mutually exclusive, since one case may include investments in property as well as investments in companies.

b 143 Assets are coded as an investment in a company as well as an investment in real estate.

\section{Property}

As is clear from Table 1, real estate objects and companies are dominant in the investment portfolios of organized crime offenders (see also Webb and Burrows, 2009: 27; Matrix Knowledge Group, 2007: 39; Malm and Bichler, 2013). In this subsection we focus on real estate objects.

From an offender's point of view, investing the profits of crime in real estate has a number of advantages. First, real estate is, or was, viewed as a safe investment that pays off. Second, because of the price level, real estate is able to absorb a lot of money. A third advantage lies in the lack of price transparency of property markets. Fourth, ownership of property can be concealed, by using legal entities for example. Fifth, criminals need a place to live as well (Soudijn and Akse, 2012; WEF, 2011: 9-11; Van Gestel, 2010; KLPD, 2008: 141; Kruisbergen, Van de Bunt et al., 2012: 214). ${ }^{106},{ }^{107}$

Residential use of real estate turns out to be an important factor when we look closer into the real estate objects in our dataset, especially when we focus on the most comprehensive category of criminal activity that includes drug trafficking, human smuggling/trafficking, and illegal arms trade, among other crimes (Table 2). Almost $45 \%$ of the 243 individual real estate objects that were found in those cases, concerns property for residential use. It includes houses and flats used by the offenders themselves or their relatives, but also houses

106 In some cases, offenders might invest in real estate to obtain or strengthen control over a territory (Transcrime, 2013).

107 Recently, various measures have been (are being) developed to limit the vulnerability of the property market to money laundering. At the moment when this thesis was finalized (summer 2016), it was not yet clear how these measures, such as the implementation of the fourth EU anti-money laundering directive (Directive (EU) 2015/849), will work out (see also Minister van Veiligheid en Justitie, 2016). 
and flats rented out to others. The property varies from very modest dwellings to very roomy and luxurious villas. The importance of real estate for residential use is confirmed by other authors who looked into the expenditure patterns of offenders (Fernández Steinko, 2012; Van Duyne and Soudijn, 2010: 271; Van Duyne, 2003: 98-101; Schneider, 2004; Transcrime, 2013; Petrunov, 2011: 177-178).

Slightly more than $18 \%$ of the real estate objects in this category of cases concerns property for business use (commercial property), such as shops, hotels, restaurants, or commercial properties in the red light district, such as casinos or brothels. ${ }^{108} \mathrm{We}$ also found investments $(11.5 \%)$ in land without buildings, especially in foreign countries. 'Other' type of real estate objects $(25.5 \%)$ includes property such as car ports and real estate objects of which it was unclear for which purposes they were used.

The real estate portfolio of offenders in fraud and money laundering cases consists for a much greater part, $69.6 \%$, of property for commercial use. This includes the aforementioned shops and hotels but especially real estate companies, e.g. companies that buy and/or sell real estate.

\section{Companies}

In 113 of the 150 cases of the Dutch Organized Crime Monitor information was present on investments in legal firms. These 113 cases accounted for investments in 892 companies. In most cases these concern companies in which an offender is somehow personally involved, i.e. companies that are (partially) owned or controlled by an offender and that are used for criminal purposes and/or in which actual economic activity takes place on behalf of the offender. ${ }^{109},{ }^{110}$

To gain more insight into what kind of sectors offenders most frequently are involved in, we compare their companies with the distribution among different sectors within the economy as a whole (see Riccardi, 2014). This comparison only involves those companies that are located in the Netherlands; 614 companies, 44 of which could not be categorized into an economic sector. Table 3 describes the distribution among different economic sectors for the remaining 570 companies (column '\%').

108 If an offender owns the property in which commercial activity takes place, the asset, such as a restaurant or a hotel, is coded as company as well as real estate.

109 Not every company is owned or controlled by one offender; ownership or control might be shared with others. Companies in which several offenders are involved, are entered only once in the dataset.

110 Purely financial assets, by which we mean bonds, options and stocks in companies in which offenders are not personally (or indirectly) involved, such as stocks in companies noted on the stock exchange, are discussed in section 4.4.2. 
Table 2. Real estate objects of organized crime offenders: type of object per category of criminal activity, number and percentage of objects

\begin{tabular}{llll}
\hline & Drugs and other crimes $^{\mathrm{a}}$ & Fraud/money laundering $^{\text {Total }}$ \\
\hline Real estate for residential use & $44.9 \%(109)$ & $24.5 \%(50)$ & $35.6 \%(159)$ \\
Commercial properties/real estate companies & $18.1 \%(44)$ & $69.6 \%(142)$ & $41.6 \%(186)$ \\
Land without real estate & $11.5 \%(28)$ & $0 \%(0)$ & $6.3 \%(28)$ \\
Other/unknown & $25.5 \%(62)$ & $5.9 \%(12)$ & $16.6 \%(74)$ \\
Total & $100 \%(243)$ & $100 \%(204)$ & $100 \%(447)$ \\
\hline
\end{tabular}

${ }^{a}$ Human smuggling, human trafficking, illegal arms trade and other.

Table 3. Investments (or other involvement) of organized crime offenders in Dutch ${ }^{\mathrm{a}} \mathrm{com}^{-}$ panies: distribution across economic sector (NACE 20021 digit) per category of criminal activity, percentage of companies and compared to economy in general

\begin{tabular}{|c|c|c|c|c|c|c|c|}
\hline \multicolumn{2}{|c|}{ Economic sector (NACE 20021 digit) } & \multicolumn{2}{|c|}{ Drugs and other crimes ${ }^{b}$} & \multicolumn{2}{|c|}{ Fraud/money laundering } & \multicolumn{2}{|l|}{ Total } \\
\hline & & $\%$ & Ratio $^{c}$ & $\%$ & Ratio $^{c}$ & $\%$ & Ratio $^{c}$ \\
\hline$A / B$ & $\begin{array}{l}\text { Agriculture, hunting and } \\
\text { fishing }\end{array}$ & 0 & 0.00 & 0 & 0.00 & $0 \%$ & 0.00 \\
\hline C & Mining and quarrying & 0 & 0.00 & 0 & 0.00 & $0 \%$ & 0.00 \\
\hline D & Manufacturing & $1,9 \%$ & 0,27 & $1,1 \%$ & 0,15 & $1.4 \%$ & 0.19 \\
\hline$E$ & $\begin{array}{l}\text { Electricity, gas and water } \\
\text { supply }\end{array}$ & 0 & 0.00 & 0 & 0.00 & $0 \%$ & 0.00 \\
\hline $\mathrm{F}$ & Construction & $1,5 \%$ & 0,14 & $4,4 \%$ & 0,42 & $3.3 \%$ & 0.32 \\
\hline G & $\begin{array}{l}\text { Wholesale and retail trade, } \\
\text { repair }\end{array}$ & $44,2 \%$ & 1,74 & $11,5 \%$ & 0,46 & $23.3 \%$ & 0.92 \\
\hline H & Hotels and restaurants & $14,1 \%$ & 2,37 & $8,2 \%$ & 1,39 & $10.4 \%$ & 1.74 \\
\hline I & $\begin{array}{l}\text { Transport, storage and } \\
\text { communication }\end{array}$ & $8,7 \%$ & 2,11 & $4,4 \%$ & 1,06 & $6.0 \%$ & 1.44 \\
\hline J & Financial intermediation & $5,3 \%$ & 2,41 & $24,5 \%$ & 11,04 & $17.5 \%$ & 7.92 \\
\hline K & $\begin{array}{l}\text { Real estate, rentingand } \\
\text { businessactivities }\end{array}$ & $10,7 \%$ & 0,52 & $43,1 \%$ & 2,11 & $31.4 \%$ & 1.54 \\
\hline 0 & $\begin{array}{l}\text { Other community, social } \\
\text { and personal service activities }\end{array}$ & $13,6 \%$ & 1,93 & $2,7 \%$ & 0,39 & $6.7 \%$ & 0.95 \\
\hline \multicolumn{2}{|c|}{ Sub-total } & $\begin{array}{r}100 \% \\
(206)\end{array}$ & & $\begin{array}{r}100 \% \\
(364)\end{array}$ & & $\begin{array}{r}100 \% \\
(570)\end{array}$ & \\
\hline \multicolumn{2}{|c|}{ Sector unknown } & $(15)$ & & (29) & & (44) & \\
\hline \multicolumn{2}{|c|}{ Total } & $(221)$ & & (393) & & (614) & \\
\hline
\end{tabular}

a 'Dutch' refers to the location of the company.

${ }^{\mathrm{b}}$ Human smuggling, human trafficking, illegal arms trade and other.

${ }^{c}$ Percentage of Dutch companies of organized crime suspects that is (formally) active in an economic sector divided by the 16-year average (1994-2009) percentage of all Dutch companies active in the same sector. Scores $0<1$ refer to underrepresentation, scores $>1$ refer to overrepresentation. 
The column labelled 'ratio' shows the relative size of an economic sector within offenders' portfolios as compared to the size of the same sector within the economy as a whole (NACE 20021 digit). Since the data on companies of organized crime suspects were collected during a longer period of time, we use data on the Dutch economy that covers a similar time span. The 'ratio' is calculated by dividing the percentage of companies of organized crime suspects that is (formally) active in an economic sector, by the 16-year average (1994-2009) percentage of all Dutch companies active in the same sector. ${ }^{111}$ Scores smaller than 1 refer to underrepresentation, which means that in our cases the percentage of companies that falls within that specific sector is smaller than it is in the Dutch economy as a whole. Values greater than 1 refer to overrepresentation. For example, $1.4 \%$ of Dutch companies of organized crime suspects fall within the sector manufacturing, whereas for Dutch economy as a whole the 16-year average percentage of companies active in this sector is $7.3 \%$, which leads to a ratio of $(1.4 / 7.3=) 0.19$.

As far as Dutch companies are concerned, only very few investments are made, in terms of percentage of investments as well as compared to the Dutch economy as a whole, in agriculture, hunting and fishing (sector $\mathrm{A} / \mathrm{B}, 0 \%)$, mining and quarrying $(\mathrm{C}, 0 \%)$, manufacturing (D, $1.4 \%$ for total sample) and electricity, gas and water supply (E, $0 \%)$. This holds for both categories of criminal activity.

Looking at the assets of offenders within the most comprehensive category of criminal activity, wholesale and retail $(\mathrm{G})$ proves to be an important sector for investments; $44.2 \%$ of companies that were found in cases that focus on, amongst other crimes, drug trafficking, human smuggling/trafficking and illegal arms trade, are active in this sector. The companies in this sector that offenders invest in involve, for example, companies importing/exporting fruit or other goods, car companies, clothing firms, and 'coffee shops'. ${ }^{112}$ Other sectors/ companies that offenders frequently invest in are hotels, bars and restaurants (sector $\mathrm{H}$ ), transportation companies (I), and brothels (coded as 'other services', sector O). Offenders also frequently 'invest' in companies that belong to 'financial intermediation'(sector J). This generally does not involve banks but 'management' or 'investment companies' which main purpose is to hold other assets (real estate for example).

In cases of fraud and money laundering we found a partly different investment portfolio. Investments in companies in those cases more frequently involve real estate companies (sector $\mathrm{K}$ ), and the afore mentioned 'management/investment' or 'holding companies' (sector J).

111 The data on assets of organized crime suspects were collected during 1996-2011 (see section 4.3). Logically, however, the investments themselves took place earlier. Furthermore, 2009 is the most recent year for which information is available on industrial classification that is comparable with earlier years (the Dutch classification of economic activities used by Statistics Netherlands (CBS) changed in 2008). Therefore, we used data on Dutch economy during 1994-2009.

112 In the Dutch meaning of the word, i.e. shops selling cannabis. 
The following cases present examples of offenders who invest in wholesale/retail and restaurants, among others.

The criminal group smuggles cocaine from South-America to the Netherlands. Suspects are involved in several companies in their SouthAmerican land of origin as well as in the Netherlands - their country of residence. These companies concern, among others: a fish wholesale company, money transfer offices, liquor stores and car companies. The fish wholesale company is used to legitimize transports from South-America to the Netherlands. The money transfer offices are used to transfer criminal proceeds. Available information suggests that the liquor stores and car companies are also used for money laundering purposes (Case 128).

The criminal group for a large part consists of family members who originate from Turkey but who live in the Netherlands. They run a human smuggling operation. Illegal Turks are smuggled from France, Belgium and the Netherlands to England. The family owns four houses, two shops, and land in Turkey. In the Netherlands they have invested in a bar and a restaurant, which are used as an operating base for running the smuggling activities as well as a working place for the illegal immigrants. The offenders also own a restaurant in England, which is used for the English part of the smuggling operation (Case 35).

Companies, as is clear from the previous examples, might be used to support criminal activities. For more than half (53\%) of the 892 (Dutch or foreign) companies that organized crime suspects invest in, the case file holds information indicating that the company is used for criminal activities. ${ }^{113}$ Suendorf (2001), Schneider (2004), Transcrime (2013), Malm and Bichler (2013), Matrix Knowledge Group (2007), and Petrunov (2011), among others, also described the use of legal firms for criminal purposes. A legal company may serve different kinds of goals (Bruinsma and Bovenkerk, 1996; Kruisbergen, Van de Bunt et al., 2012: 297). First, a company might be used for logistic support, i.e. storage, transport or meeting place. A transportation company, for example, might be used for transportation of illegal goods. Second, a legal firm may serve to legitimize and/or conceal criminal activity; a cleaning company, for example, can be used to order certain chemicals needed for producing synthetic drugs, and a fruit company can provide offenders with cargo as

113 The information on the use of companies for criminal activities generally originates from intelligence and has not been confirmed by a judge. However, since for many companies the case file lacks information regarding the use for criminal activities, the real use for criminal purposes is probably higher. 
cover for a drug transport. Third, companies can be used for money laundering purposes; a company can serve to, for example, fake a legal profit or salary, absorb cash money, or to conceal the ownership of other assets (Schneider, 2004: 45).

Companies that are used for criminal purposes might be merely shell companies or façades, but they might also deploy real licit economic activities. Particularly if an offender can make use of a company that is engaged in legal economic activities on a certain scale, it provides him with a good opportunity to place illegal funds, among other things (Levi and Reuter, 2009).

Although investments in legal economy can support criminal operations, they might also prove to be a vulnerability. This is illustrated by the following case, which focusses on a main suspect and his fellow offenders who are involved in large-scale cannabis trafficking. In their criminal operations, an important role is played by so-called 'grow shops'; shops that provide equipment, such as light bulbs, for growing (hemp) plants indoors. The shops are legal, but it is forbidden for them to sell sprigs or weed. In this case several grow shops do sell weed to K, the main suspect. However, as this case illustrates, these shops, besides offering possibilities to criminals, might also present possibilities to the police to deploy certain methods of criminal investigation.

The offenders have six grow shops at their disposal. From one of those grow shops, tens of kilos of cannabis were sold to K. The police targets the grow shop in an undercover buy-bust operation. An undercover agent succeeds in buying two kilos of weed. Subsequently, a number of suspects were arrested, the premises were searched, and the shop's bookkeeping and records were confiscated (case 122).

\subsubsection{Scope of investments}

In this subsection we will look into the social economic as well as the geographical scope of the investments of organized crime offenders.

\section{Social economic scope}

A first aspect of the social economic scope relates to the actor who invests. D'Andria, who, like some other authors, assumes that criminal 'entrepreneurs' apply the same management strategies as their licit counterparts do, distinguishes between economic behaviour of criminal individuals on the one hand and economic behaviour of criminal organizations on the other. A criminal organization is assumed to be a separate entity with its own rationale (D'Andria, 2011: 5-6).

On theoretical grounds one might argue whether a criminal 'enterprise' really transcends its individual 'employees' and has a rationale of its own. After all, due to the illegal nature of criminal 'enterprises' and the risks that go with it, 'employees' or individual 'businessmen' 
have a strong incentive to earn and spend money according to the principle of each man for himself. ${ }^{114}$ An empirical-theoretical argument against D'Andria's assumption follows from research findings on the structure of cooperation between organized crime offenders in the Netherlands. For most cases, this structure is best described by the term 'criminal networks'; the structure of cooperation is fluid and changes over time (Kleemans et al., 2002; Kleemans, 2007: 178-179). It seems unlikely that the flexible nature of cooperation in those cases could bring about economic behaviour on behalf of 'the organization'.

A final - empirical - argument comes from the cases we studied. We did not systematically register for each case whether or not investments are made on behalf of a collective. Information that would allow for this is often lacking. In so far as available information indicates, however, the cases do no present evidence that organized crime investment portfolios in general are collective in nature. In some cases, such as some family based groups, the criminal group or organization indeed transcends the individual members and investments are made on behalf of the organization (or family or group). However, in other cases, available information suggests that profits and investments are individualized and there is no collective 'business capital' (Kruisbergen, Van de Bunt et al., 2012: 300-301). In those cases, the time horizon of the criminal 'enterprise' is much shorter than the time horizon of a licit enterprise (Naylor, 2002: 20-21), which probably will limit the scope of investments.

A second aspect of the scope of investments concerns the actual investments themselves; what is bought and what is not? In a sense, investment portfolios are rather conservative. If we focus on offenders in drug trafficking, human smuggling/trafficking, and illegal arms trade, among other crimes, it turns out that offenders predominantly invest in real estate, residences in particular, and companies, i.e. wholesale/retail companies, hotels, bars and restaurants, transportation companies and brothels. Offenders thus invest in goods and companies that, one might say, they are familiar with from everyday life (see also Bruinsma, 1996; Kleemans et al., 2002; Van Duyne and Levi, 2005). In many of the companies just mentioned offenders are somehow personally involved, i.e. companies are (partially) controlled by an offender and are used for criminal purposes and/or actual economic activity takes place within the company on behalf of the offender. Purely financial assets on the other hand, by which we mean bonds, options, and stocks in companies in which offenders are not personally involved, such as stocks in companies noted on the stock exchange, were only found in a small number of cases. ${ }^{115}$

\footnotetext{
114 Whether or not a criminal organization exists as a separate entity that transcends its individual members, might very well depend on the type of organized crime, such as transit crime or 'Mafia-type' organized crime, or other characteristics, such as family ties as a binding mechanism within a group.

115 Besides the assets we discussed so far, a small number of other investments were found, such as a power generator and sports sponsoring.
} 
A third and final aspect of the social economic scope of investments involves the influence offenders might gain through their investments. Data on organized crime in the Netherlands present some cases of offenders who gained some influence on the local level. This involves, for example, offenders who owned a large real estate portfolio, concentrated in a smaller town or a specific neighbourhood in a city, and became a factor to be considered in development plans of a municipality (Kruisbergen, Van de Bunt et al., 2012: 182-183; Soudijn and Akse, 2012: 134-138). However, in our cases we found no examples of offenders whose investments allowed them to reach from the 'underworld' to powerful social, economic or political positions on a higher, national level in the Netherlands. ${ }^{116}$ No examples were found of investments that would enable offenders to monopolize or control a region or a sector, such as the construction industry or any other sector for that matter. In cases of drug trafficking, human smuggling/trafficking and illegal arms trade in particular, most assets concern houses and other real estate and companies that through their size and nature do not account for significant influence in Dutch society (see also Van Duyne, 2003: 98-101; Van Duyne and Levi, 2005; for Spain: Fernández Steinko, 2012: 919).

This does not mean that our data do not include offenders with relevant positions in licit society. These offenders are present in our dataset. In a small number of cases of fraud and money laundering, some offenders have very large investment portfolios and/ or have an impressive professional background. However, in those cases, as information in at least some of them indicates, the movement between the 'underworld' and the 'upper world' went in the opposite direction. This concerns three cases in which people with well-established positions in the licit economy and without a criminal record, used their position to set up a rather big fraud or money laundering scheme. So in fact, these cases are about 'legal and respected' businessmen who got involved in organized crime, instead of criminals who, by investing their dirty money, infiltrated respectable business (see also Fernández Steinko, 2012: 919). The following case presents an illustration (Kruisbergen, Van de Bunt et al., 2012: 135).

The main suspects in this large scale fraud scheme hold central, licit positions within the real estate sector. They abuse those positions to enrich themselves with many millions at the expense of the organizations they work for. The suspects use fake bills provided by their own companies and/ or a bank account of a notary public to divide the criminal earnings (case 143 and 144).

116 In some cases there are indications that offenders, by contacts with (corrupt) people within the government or law enforcement and/or as a consequence of their investments, might have obtained influence in a foreign country (their country of origin) (see also Van Duyne, 2003: 98-101). 
The type of investments we found - and did not find - in our cases can partially be explained by the nature of organized crime in the Netherlands. Kleemans used the term transit crime to describe the nature of organized crime in the Netherlands; offenders are primarily involved in international illegal trade, i.e. international smuggling activities. In this type of organized crime, the Netherlands serves either as a country of destination, a transit country, or a production country (Kleemans, 2007). Offenders simply use the legal opportunities, such as the economic and physical infrastructure, instead of trying to 'infiltrate' or monopolize it, which explains the general lack of 'strategic' investments. ${ }^{117}$

The choices or strategy of investments may be quite different in 'Mafia-type' organized crime. The main activities of Mafia organizations may be described, at least historically, as racketeering. In racketeering, controlling and monopolizing sectors or regions is an important part of the criminal business model (see also Gambetta and Reuter, 1995: 116, 133-134). That might very well affect the investment choices. Riccardi analysed about 2000 companies confiscated in Italy. He argues that investment choices of Mafia participants are determined by, among other factors, the possibilities to maximize territorial control and expand political and social support (Riccardi, 2014).

\section{Geographical scope}

Where do offenders invest their money? In this subsection we look into the country of investment. More interesting than the country itself, is the relation between an offender and the country he invests in. In Table 4, the country of investment of all 1,196 real estate objects and companies are broken down into three categories: investment in country of origin of the offender; investment in country of residence of the offender (if this is not the country of origin); investment in another country. Investments of indigenous Dutch offenders in the Netherlands are classified as 'country of origin'. To determine the country of origin/residence of the offender who owns the asset, we looked at the de facto ownership/ control of the asset. If, for example, available information indicated that behind a person who has formal ownership rights another person is hidden who has actual control of an asset, we used the latter.

117 Another explanation might be found in the low level of corruption - or the high level of transparency - in the Netherlands (Transparency International, 2012), which reduces the possibility for 'strategic investments'. 
Table 4. Investments of organized crime offenders in real estate objects and companies: country of investment, number and percentage of assets

\begin{tabular}{|c|c|}
\hline Country of investment ${ }^{a}$ & Total number of assets $\%(\mathrm{~N})$ \\
\hline Country of origin & $62.5 \%(748)$ \\
\hline Country of residence & $19.6 \%(234)$ \\
\hline Subtotal: country of origin or country of residence & $82.1 \%(982)$ \\
\hline Other country & $17.9 \%(214)$ \\
\hline Total & $100 \%(1,196)$ \\
\hline
\end{tabular}

${ }^{a}$ Assets of indigenous Dutch offenders in the Netherlands are classified as assets in 'country of origin'.

It turns out that $62.5 \%$ of all assets are located in the country of origin, i.e. the Netherlands for indigenous Dutch offenders, Turkey for offenders who originate from Turkey, et cetera. Assets in the country of residence account for $19.6 \%$ of all assets. So, altogether, investments are predominantly made in offenders' 'home' countries; $82.1 \%$ takes place in the country of origin or the country of residence. Only $17.9 \%$ of the assets are located in another country. ${ }^{118}$ The Netherlands is the most frequently used country by far $(64.4 \%$ of all assets). For some offenders this is the country of origin, for others it might be the country of residence. Other frequently used countries are Turkey (4.8 \%), Suriname (3.3 $\%)$ and Belgium (3.3\%). All in all, the geographical scope proves to be rather limited, at least as far as real estate objects and companies are concerned (see also Webb and Burrows, 2009: 27; Van Duyne and Levi, 2005; Suendorf, 2001). ${ }^{119},{ }^{120}$

118 In cases of drug trafficking, human smuggling, human trafficking and illegal arms trade, $21.8 \%$ of all investments take place in 'another country'. In cases of fraud and money laundering, this holds for $13.8 \%$ of the investments.

119 Suendorf (2001) finds that migrant offenders frequently invest in their country of origin. That holds for Turkish, Italian, Albanian, Serbian, Kosovo-Albanian as well as Vietnamese offenders. Russian offenders on the other hand, according to experts Suendorf interviewed, invest their money for a large part in Europe and the United States.

120 In its Global Agenda Council on Organized Crime, the World Economic Forum gives examples of organized crime offenders' investments in real estate with a more prominent international dimension (WEF, 2011). 


\subsection{Conclusion and discussion}

\subsubsection{Empirical results}

In the previous section we presented the results of analyses on a dataset of 1,196 assets that are linked to organized crime offenders. In the portfolios of these offenders, real estate objects and companies are dominant. ${ }^{121}$ Investments in real estate consist for a large part of residences. As far as companies are concerned, offenders frequently are involved in wholesale and retail such as fruit importing companies or shops, hotels and restaurants, transportation companies, brothels and 'management' or 'investment companies' which main purpose is to hold other assets (real estate for example). A number of cases of fraud and money laundering display a different pattern. Their assets more frequently concern commercial real estate, real estate companies and the aforementioned 'management/ investment' companies. In general, investments in agriculture and fishing, mining, manufacturing, and energy are absent or strongly underrepresented. For more than half of the companies offenders invest in, available information indicates that the company is used for criminal activities, i.e. for money laundering purposes, logistics, and/or legitimization.

Offenders do not frequently invest in purely financial assets, i.e. bonds, options and stocks in companies in which offenders are not somehow personally involved, such as stocks in companies noted on the stock exchange. Those assets were found in only a small number of cases.

As far as the place of investment is concerned, it turns out that offenders predominantly invest in their home country.

\subsubsection{Profitability, power, ... or proximity?}

The empirical results allow us to post-hoc evaluate the validity of some theoretical perspectives and assumptions with regard to organized crime and investments in the licit economy.

The standard economic approach assumes that profitability is the main determining factor in the investments choices of offenders. It assumes that organized crime offenders, just like licit entrepreneurs, make cost/benefit efficient investments in a globalized economy. Offenders are also supposed to be very flexible when it comes to switching between countries or economic sectors. However, our empirical results show that offenders predominantly invest in their home country. We focused on de facto ownership (control) instead of formal ownership and we did not include cash money and deposits in our analyses. Including formal ownership as well as cash money and deposits might lead to different

121 Although involvement in companies is frequently found in organized crime cases in the Netherlands, companies are not frequently seized for confiscation (Van Duyne and Soudijn, 2009). In Italy confiscation of companies is far more common (Riccardi, 2014; Transcrime, 2013). 
results. Nevertheless, at least as far as de facto ownership (control) of real estate objects and companies is concerned, the geographical scope of offenders' investment portfolio's is rather limited, and certainly not as 'global' as assumed. Furthermore, the importance of property within their investments portfolios, limits offenders' flexibility. When a big share of your money has been invested in houses and other real estate, it probably will not be easy to swiftly withdraw your money and move it to another country of investment, at least not without high costs. ${ }^{122}$

Offenders, in cases of drug trafficking, human smuggling/trafficking and illegal arms trade in particular, mainly invest in houses and other real estate, as well as in companies they are familiar with from everyday life and that are used in many cases for criminal purposes. Investments in purely financial assets, on the other hand, were only found in a small number of cases.

Certainly, offenders will not mind making a profit. Indeed, investments in real estate, for example, can be quite profitable (although recent history has shown that this needs not be the case). However, the lack of 'global flexibility' and the rather conservative nature of the investment portfolios indicate that the standard economic approach does not suffice to describe the investment choices of organized crime offenders.

In the criminal infiltration approach, the motivation behind - or the consequences of the investment choices offenders make, can be summarized as power; investing in the licit economy brings power and influence. Our data, however, do not support the 'infiltration hypothesis'. No examples were found of investments that would allow offenders to reach from the 'underworld' to powerful legitimate positions in the Netherlands, certainly not on a national level. The data do include a small number of offenders with (very) well established positions in the licit economy, but (some of) those cases are illustrations of, one might say, infiltration the other way around; 'legitimate' businessmen and professionals without a criminal record who utilize their position in the licit economy to set up criminal activities.

Concluding, the assumptions of both these two perspectives do not fit our empirical results. Therefore we have to explore other perspectives. The results of our study show that the distance between the offender and his assets is often small, comprising both physical and social distance. They predominantly invest in their country of origin or in the country of residence, their investments consist of tangible, familiar assets such as residences and other real estate and (small) companies from well-known sectors, whereas purely financial assets, i.e. bonds, options and stocks in companies in which offenders are not somehow personally involved, are far less common. In other words: offenders usually stay close to

122 The fact that, at least in part of the cases, profits and investments are individualized and there is no collective 'business capital', is another point on which the comparison between organized crime and licit enterprise is flawed. 
home with their investments. So, instead of profitability or power, proximity seems to be a better description of their investment choices. This 'proximity' actually fits pretty well with a social opportunity approach regarding organized crime (cf. Kleemans and De Poot, 2008).

The concept of social opportunity structure merges social network theory (e.g. Burt, 1992) and opportunity theory (e.g. Clarke and Felson, 1993). Economic behaviour is embedded in social relations (see also Granovetter, 1985; Uzi and Lancaster, 2004; Kim and Skvoretz, 2013). Because of the lack of formal regulations and the constant threat of arrest, seizures or other sanctions, social ties and trust are even more important in criminal transactions (e.g. Kleemans and Van de Bunt, 1999; Morselli, 2009; Kleemans, 2014b; Beckert and Wehinger, 2013: 17-18, 21; Loughran et al., 2013: 6). Offenders have to know the right people to participate and succeed in organized crime; you have to have access to producers, clients, facilitators, and so on. For this purpose an offender uses existing social ties, or he tries to find new contacts.

The amount and quality of social capital differs among offenders. Therefore, Kleemans and De Poot (2008) coined the term 'social opportunity structure' to explain involvement in organized crime: criminal opportunities depend on social ties, which in turn depend on one's age, social, geographical and ethnic background, occupation, et cetera. This social opportunity structure not only applies to involvement mechanisms in organized crime, it is also useful to understand the choices offenders make when they invest the profits of crime: their options for investment are defined - and limited - by the opportunities offenders find in their direct social environment.

\subsubsection{Implications}

In this chapter we have given empirical insight into the assets of organized crime offenders in the Netherlands and we explored the value of different theoretical perspectives on offenders' investment behaviour. We argued that 'proximity' seems to be a better label for the investment choices offenders make than 'profitability' or 'power'. We do not pretend, however, to have given a completely unequivocal or 'final' answer to our research questions. Every research has its limitations. This especially holds for research on criminal phenomena. Our research is based on police files. Consequently, our study only involves cases that were prioritized by the police and in which offenders were caught. A further bias results from the fact that only those assets were included on which the cases could produce some information. Research based on police files always runs the risk that certain findings remain absent, not because the facts are not there, but simply because the police could not find them. This could lead to an underestimation of the importance of some types of assets or certain methods of money laundering, such as the use of secrecy havens, for example.

Although research on criminal activities has its limitations, it is the only way of acquiring knowledge. Until now, empirical research on how offenders actually spend their earnings is 
relatively scarce. As a consequence, debate as well as policy lack a firm empirical basis.

A higher level of useful knowledge requires quantitative research on topics such as the type, magnitude and place of investment, as well as qualitative, in-depth research into the mechanisms and considerations that shape the spending behaviour of organized crime offenders. To gain more insight into the considerations of offenders when spending their money, effort should be put into getting information from the ones who know best, the offenders themselves. Interviewing offenders might also partially compensate for the bias resulting from relying on police files, although we realize that this method has its own difficulties.

Since financial aspects of organized crime are a neglected field in empirical research, future research could address a broad range of questions. A specific subject of interest, however, is 'digital methods' of money laundering. Knowledge on the use of crypto currencies for money laundering purposes, for example, hardly rises above the anecdotal level.

Furthermore, research should as much as possible differentiate between different types of organized crime. Our study involved organized crime in the Netherlands. Dutch organized crime, as mentioned earlier, for a large part boils down to transit crime, i.e. international illegal trade. Research on offenders who participate in other kinds of organized crime, such as racketeering, might produce (partially) different results, as is indicated by research on Mafia investments (e.g. Riccardi, 2014). Furthermore, we found some differences within our own data; between cases of drug trafficking, human smuggling, human trafficking, and illegal arms trade on the one hand, and cases of fraud and money laundering on the other. This, together with the fact that many offender-owned companies are used for criminal activities, implies that the nature and logistics of organized crime are important factors in offenders' portfolios (see also Sieber and Bögel, 1993). For understanding as well as combating organized crime, it is therefore essential to account for different types of this phenomenon.

Finally, the apparent absence of a 'power' motive in cases of organized crime in the Netherlands and the fact that offenders for a large part invest in their own environment, do not mean that we should not worry about criminal earnings and investments or that the police should not put too much effort in investigating it. Neglecting financial investigation might cause, in effect, some offenders to accumulate an investment portfolio that actually does bring power. Furthermore, the wealth of a criminal can lead to recruitment of potential new offenders, exactly because the spending predominantly takes place in a criminal's own social environment. 


\section{Explaining attrition: investigating and confiscating the profits of organized crime}

In this chapter, we provide insight into a common but scarcely researched problem in the process of confiscating criminal earnings: attrition, that is, the gap between estimated criminal profits on the one hand and the actually recovered amount of money on the other. ${ }^{123}$ We investigate the practice and results of financial investigation and asset recovery in organized crime cases in the Netherlands by using empirical data from the Dutch Organized Crime Monitor, confiscation order court files, and the Central Fine Collection Agency. The data shed light on financial investigation in practice and give a complete picture of the confiscation order court procedures as well as the execution of those orders for 102 convicted offenders - from public prosecutors' claims and rulings of the initial court, the appeal court and the Supreme Court, to what offenders actually pay. The phenomenon of attrition can be explained by several factors, but an important factor turns out to be how 'criminal profit' is defined (determined) in law and practice.

\subsection{Introduction}

In many countries around the world, 'follow the money' has become a key concept in policy plans against crime. The focus has shifted from investigating, arresting and prosecuting offenders to taking away their money. In order to stimulate the seizure of criminal earnings, legislation has been implemented, specialized organizations have been set up, and available resources have been increased (Bartels, 2010: v; Brå, 2008; Hofmeyr, 2013; Levi, 2013; Vettori, 2006: 113). Several countries amended legislation to further enhance the possibilities for confiscation (Cabana, 2014: 17-18; Freiberg and Fox, 2000: 239-240; Kennedy, 2007: 33-34; Lusty, 2002: 345, 351).

The underlying theory - goals and assumptions - of the follow-the-money approach can be summarized as follows. First, confiscating 'dirty money' deters crime by reducing its

\footnotetext{
123 A slightly different version of this chapter was earlier published as: Kruisbergen, E.W., Kleemans, E.R. and Kouwenberg R.F. (2016). Explaining attrition: Investigating and confiscating the profits of organized crime. European Journal of Criminology, DOI: 10.1177/1477370816633262.
} 
profitability. Second, it prevents crime by diminishing the capacity of offenders to finance any future criminal activity. Third, it reinforces the norm that 'crime should not pay'. Fourth, it compensates society for the adverse impacts of crime and the costs of fighting it (Bartels, 2010: v; Lusty, 2002: 345; Nelen, 2004). ${ }^{124}$

In recent years, the amount of recovered money has grown considerably, for example in the United Kingdom and the Netherlands (Levi, 2013: 10; Bullock et al., 2009: ii; Openbaar Ministerie, 2014, 2015, 2016). However, although the value of recovered assets is rising, many countries are confronted with the problem of attrition, that is, the gap between estimated criminal profits on the one hand and the actually recovered amount of money on the other. The results are below initial political expectations, for example regarding the number of cases in which asset recovery is applied, the collection of confiscation orders, or the recovered sum in relation to the entire criminal economy (Bullock et al., 2009: ii; Cabana, 2014: 17; Freiberg and Fox, 2000: 253; House of Commons, 2014; Levi, 2013: 3; Nelen, 2004: 520-522; Van Duyne et al., 2014).

\subsubsection{Present study: purpose and research questions}

Although asset recovery as a tool to fight organized crime has received support as well as criticism, empirical research on the follow-the-money strategy is scarce (Collins and King, 2013; Fleming, 2008: 9, 10, 21; Freiberg and Fox, 2000: 239-242). In this chapter, we contribute to a better understanding of how this strategy operates in practice and provide explanations for the problem of attrition. Using three empirical data sources, we look into the practice and results of financial investigations and asset recovery in organized crime cases in the Netherlands. We focus on organized crime because the financial approach is supposed to be an important tool to fight this type of crime. We address two research questions: (1) How do the investigation and confiscation of criminal profits work out in organized crime cases? (2) What explanations can be offered for the phenomenon of attrition?

In the next section (5.2), we look into prior empirical research. In section 5.3, we explain the data we use. In section 5.4, we explain the institutional framework of 'follow the money' in the Netherlands. Subsequently, we present the results and provide empirical insight into financial investigations (section 5.5), confiscation order court procedures (section 5.6), and the collection of confiscation orders in organized crime cases in the Netherlands (section 5.7). In section 5.8, we summarize the empirical results, explore possible implications, and suggest options for further research.

124 Furthermore, financial investigations may result in convictions that would not have been achieved otherwise (Brown, 2013). 


\subsection{Prior research}

Debates on criminal law and policy often have a strong normative component. Policymakers, among others, stress the importance of asset recovery as a tool to make sure that crime does not pay; it is supposed to 'hit them where it hurts most' (Nelen, 2004). At the same time, this approach is criticized by authors who, for example, suggest that it has unintended consequences and/or argue that asset recovery regimes conflict with judicial standards. However, the empirical foundation of the legislative and academic debate is poor (Collins and King, 2013; Fleming, 2008: 9, 10, 21; Freiberg and Fox, 2000: 239-242). Some earlier, valuable research exists. Fleming (2008), for example, explored the 'judgment proof status' of convicts who received a confiscation order, that is, the ratio between the confiscation order as inflicted by the court and the established amount of criminal benefit. He did not look into the actual payment (collection) of the confiscation orders. A more comprehensive picture of attrition in England and Wales is provided by Bullock et al. (2009), who presented a quantitative overview of the confiscation procedure for 3,604 cases. To explore reasons for attrition they also examined a sub-sample of cases in more detail and interviewed practitioners.

Nelen and Sabee (1998) conducted an in-depth evaluation of Dutch confiscation legislation. Besides interviews and analyses of databases focusing on a specific phase of confiscation, they examined 58 appeal court cases for which they had information on all steps from the prosecutor's claim up to and including the appeal court decision, but excluding the phase of collection of the confiscation order. Meloen et al. (2003) also conducted a thorough study of confiscation in the Netherlands (see also Van Duyne and Levi, 2005). Their study includes information on several phases of the confiscation process, such as estimated criminal benefit during the financial investigation and the amount actually collected, but the underlying databases mostly refer to different sets of cases. More recently, Van Duyne et al. (2014) analysed the database of the Central Fine Collection Agency (CJIB), covering the collection of confiscation orders, but not including the preceding phases of confiscation. ${ }^{125}$

Besides their relatively small number, most of the existing empirical studies do not provide a complete picture for the cases studied, that is, from the investigation of the profits of crime to the actual collection of assets, and/or lack a qualitative insight into the different phases of confiscation. As a result, knowledge of 'the law in action' is limited (Vettori, 2006: 20). In this chapter, using three data sources, we look into financial investigation, give a complete picture of the confiscation order court procedures as well as the execution of those orders for 102 convicted offenders, and provide a qualitative explanation of the facts.

125 Vruggink interviewed 100 imprisoned convicts who received a confiscation order, to find out how they felt about this measure and whether the confiscation order might have any effect on criminal behaviour. 


\subsection{Methodology}

We focus on financial investigation and confiscation orders applied in organized crime cases. By 'confiscation order', we refer to the 'ontnemingsmaatregel', a measure under Dutch criminal law that can be applied against convicts to take away their criminal profit. We use three sources of empirical data. The first source consists of cases from the Dutch Organized Crime Monitor (DOCM), an ongoing research project into organized crime in the Netherlands (for more information, see Kruisbergen, Van de Bunt et al., 2012).

At the time a case is studied for the DOCM, the court procedures are often not completed, let alone the execution of measures such as confiscation orders. To collect information on confiscation orders applied in cases of the DOCM, we used a second data source: the Central Fine Collection Agency (CJIB), responsible for the execution of sanctions such as fines and confiscation orders. From the 120 cases of the first three DOCM data sweeps, ${ }^{126}$ we retrieved the names as well as date and place of birth of more than 1,600 suspects. ${ }^{127}$ These were sent to the CJIB to be matched with their confiscation database. The matching produced 119 convicts for whom it could be established that their involvement in one of the cases resulted not only in a criminal conviction but also in a confiscation order. The CJIB sent back a database with information on the actual collection of those confiscation orders.

Third, court files were analysed to retrieve information on court procedures preceding the final confiscation order (prosecutor's claim, district court's verdict, et cetera), the grounds on which a court decided whether or not to diverge from the prosecutor's claim (and/or from the decision of lower courts), and the facts and assumptions used to estimate the criminal profit. For 102 convicts the available court files produced information on all phases of the court system: the district court, the appeal court and the Supreme Court (not all cases went to higher courts). For 17 convicts, the information was not complete. The information regarding the remaining 102 confiscation cases was entered into SPSS.

These combined three data sources give insight into the financial investigations in organized crime cases, and give a complete picture of the confiscation order court procedures and the execution of those orders for 102 convicted offenders. The collection of these confiscation orders started between August 1995 and July 2011 (date of intake at the CJIB, median date May 2003). Information on the collection is up to date to 3 July 2015. On that day, the collection of 26 of the 102 confiscation orders was still ongoing.

\footnotetext{
126 Because court procedures as well as execution of confiscation orders can take a long time, the fourth DOCM data sweep was not included.

127 The more than 1,600 names include the main suspects, but also suspects who played a more peripheral role. Financial investigations often target only (some of) the main suspects, if there is sufficient evidence of criminal profits and assets.
} 


\subsection{Follow the money in the Netherlands: institutional framework}

This chapter focuses on the confiscation order. This instrument and the accompanying legislation has received the most attention in the Dutch public debate on asset recovery. The confiscation order is not the only instrument for recovering crime money. A case can be settled out of court when both the prosecutor and the defendant settle for an agreement on an amount of money the defendant is willing to pay. Another instrument is a fine, which in some cases is used for the purpose of confiscation. Furthermore, there is the possibility of seizure and forfeiture of objects that are directly linked to a crime, for example, when offenders involved in underground banking are arrested carrying tens of thousands euros in cash. ${ }^{128}$

The possibility of depriving offenders of illegally obtained profits was introduced in Dutch general criminal law in $1983 .{ }^{129}$ In 1993 new legislation was adopted to increase the statutory powers of law enforcement agencies to take away criminals' money. The new law made it possible for the prosecution, once a defendant had been convicted, not only to claim the confiscation of the earnings resulting from the facts for which he is convicted, but also to claim confiscation of profits in relation to other crimes in which he was plausibly involved. The involvement in these 'other crimes' does not have to be proven to a criminal standard; sufficient indications are adequate. Furthermore, if a defendant is convicted for an offence that falls under the most serious classification of crimes, unexplained wealth suffices to claim confiscation of profits. In that case, the prosecutor does not even have to specify a crime that generated the profit. The political debate on this legislation was inspired by the ideological notion that 'crime should not pay' and causal assumptions such as the view that taking away criminals' money acts as a deterrent and will prevent the financing of future criminal activity (Nelen, 2004: 523-524).

In 2003 and 2011, the legislation was further amended. One of the changes of 2003 concerned the possibility for the prosecution to apply for coercive custody for a maximum of three years if a convict does not pay a confiscation order. ${ }^{130}$ A convict who has served coercive custody still has to pay his confiscation order, which was not the case when an 'unwilling' convict got 'replacement custody', as was the case before 2003. New legislation in 2011 introduced, among others, the possibility to deploy special methods of criminal

128 Other instruments are: a transaction, stating conditions (for example the payment of a sum of money) under which the right to prosecute the crime that generated the profits is cancelled (an agreement cancels only the confiscation procedure), compensation for victims, and fiscal measures (Nelen, 2004: 517-520).

129 The possibility of depriving offenders of illegally obtained profits had already been introduced in Dutch economic criminal law in the 1940s (Borgers, 2001: 51-67).

130 Complete reference in Dutch: Wet van 8 mei 2003 tot wijziging en aanvulling van een aantal bepalingen in het Wetboek van Strafrecht, het Wetboek van Strafvordering en enige andere wetten met betrekking tot de ontneming van wederrechtelijk verkregen voordeel (aanpassing ontnemingswetgeving), Stb. 2003, no. 202. 
investigation, such as wiretapping, for the purpose of executing a confiscation order. ${ }^{131}$ Also the budget available for the prosecution service to take away criminals' money increased in 2011 as well as in 2013 (Borgers, 2001: 270-272; Nelen, 2004: 517-520; Van Duyne et al., 2014). ${ }^{132}$

In order to claim a confiscation order, the volume of criminal profits has to be determined by means of financial investigation, for which specialized but also regular investigative teams are used. The ultimate responsibility for the financial investigation rests with the public prosecutor.

As was explained earlier, involvement in the crimes generating profits does not have to be proven by regular standards of criminal law. The estimation of the profit itself is also subjected to a lower standard of proof than is upheld in regular criminal law cases; one piece of evidence can be a sufficient base for the estimation (Borgers, 2001: 268-270).

The law gives no definition of 'criminal profit', nor does it prescribe how criminal profit should be determined. Costs directly linked to the criminal activities under consideration may be deducted, but this is not mandatory, and a court may decide to moderate a confiscation order. What is clear from the legislative debate and rulings of the Supreme Court, though, is that the concept of 'profit' is to be understood in a broad sense. It also includes saved expenses and it is not relevant, in principle, whether or not the money is spent, for example on other criminal activities or on luxury items, or even lost, such as when a jewel thief gets robbed before he can sell his loot. What matters is the (initial) profit itself; the jewel thief has to pay the value of the items he stole (their worth on the black market), regardless of the fact he never made any money on them (Borgers and Simmelink, 2005a).

Once a person has been convicted of a crime, the prosecution service has to start a separate procedure to claim a confiscation order. A court decides on this claim, after which both the convict and the prosecution can go to the appeal court (and ultimately to the Supreme Court). Once a confiscation order is final, the case is transferred to CJIB for execution.

131 Complete reference in Dutch: Wet van 31 maart 2011 tot wijziging van het Wetboek van Strafrecht, het Wetboek van Strafvordering en enige andere wetten ter verbetering van de toepassing van de maatregel ter ontneming van wederrechtelijk verkregen voordeel (verruiming mogelijkheden voordeelontneming), Stb. 2011, no. 171.

132 In 2014 and 2015 new changes in the law came into force. Since 2015, the confiscation law contains a section that stipulates that judges can deduct costs directly linked to the criminal activities under consideration. This is in line with legal practice before this amendment came into force. However, as is clear from the explanatory memorandum, the amendment is intended to limit the actual deduction of costs (complete reference in Dutch: Wet van 19 november 2014 tot wijziging van het Wetboek van Strafrecht, het Wetboek van Strafvordering en de Wet op de economische delicten met het oog op het vergroten van de mogelijkheden tot opsporing, vervolging, alsmede het voorkomen van financieel-economische criminaliteit (verruiming mogelijkheden bestrijding financieeleconomische criminaliteit), Stb. 2014, no. 445; see chapter 6). 
In some jurisdictions, certain 'incentivisation schemes' and/or targets are used to stimulate the motivation of the organizations involved in asset recovery. In the United Kingdom and the United States, for example, part of the value of seized assets is given to the law enforcement body responsible for the seizure (Baicker and Jacobson, 2007; Levi, 2013: 10). ${ }^{133}$ Such incentives are lacking in the Netherlands. However, targets are to be achieved, or at least clearly defined objectives: the increase in the amount of recovered money should be three times greater than the additional investment in financial investigations (Government of the Netherlands, n.d.: 2).

\subsection{Financial investigation: finding clues, or not}

A confiscation order is based on an assessment of the profits of crime. Such an assessment is hindered by the fact that criminals try to hide their assets, which limits the amount of available information. In so far as the earnings are consumed, for example spent on daily expenses, this may also be hard to trace. Below we look into different types of information that can be found during a financial investigation. In particular, we explore how certain characteristics of offenders and the criminal operations they engage in relate to the amount and type of information that investigators may find. Four factors appear to be relevant: offenders' and witnesses' behaviour, the logistics and scale of criminal operations, the use of legal economic infrastructure, and operational necessities that may force offenders to expose themselves. ${ }^{134}$

Offenders, co-offenders and witnesses: vigilance and willingness to talk

Offenders differ: not all have the same degree of vigilance and discipline. Vigilance and discipline are needed, for example, to avoid communicating any concrete information regarding quantities or prices over the phone, to withstand the temptation to enjoy criminal earnings all too openly, and to make sure that the police will not find any notes or records. Although this may be pretty obvious, in daily reality it may prove quite difficult to uphold these standards, even for high-level, very experienced offenders, as is clear from the following example.

The criminal network surrounding $\mathrm{T}$ is involved in large-scale, international drug trafficking. During a raid the police seize a money counting machine, many hundreds of kilos of hashish, tens of kilos of amphetamines, tens of cell phones, and encoded bookkeeping. In the bookkeeping, codes are

\footnotetext{
133 The United States is the 'global leader' in aggressive asset forfeiture (Levi, 2013: 9). The U.S. confiscation regime includes civil as well as criminal recovery procedures. Furthermore, in many jurisdictions police agencies are allowed to keep a substantial fraction of the seized assets (Baicker and Jacobson, 2007; Worrall and Kovandzic, 2008).

134 It is not meant as an extensive overview.
} 
used to represent different types of drugs, currency, and customers. Labels with the same codes are found on the cell phones. $T$ is very much aware of potential police activity, as he uses only codes and uses a different cell phone for each 'business' contact. However, he could not prevent the police finding not only the encoded bookkeeping but also a document explaining the codes. Working through the decoded records, the police established that the turnover in 18 months was more than $€ 15,000,000$ (case 122). ${ }^{135}$

Although many co-offenders hide behind a 'wall of silence', some of them may be found willing to make statements. An offender, once arrested and on trial, may find it quite rational to give at least some information about his assets. This was the case, for example, during the court proceedings of a drug trafficker, who claimed that only $€ 50,000$ of the seized $€ 1,000,000$ in cash belonged to him (case 47). Even a suspect's statement that involves information regarding only his own earnings may prove useful to assess other suspects' earnings. In a cocaine trafficking case, the court used the amount of earnings suspect A admitted to have gained to determine the criminal earnings of suspect $\mathrm{B}$, who was assumed to hold an equal position within the criminal group (case 102).

Besides (co-)offenders themselves, there may be informers who participate in the same criminal market as the offender and who are willing to provide information, out of envy, revenge, or simply because they want to eliminate a competitor (Billingsley et al., 2001b; Van Duyne et al., 2001: 150).

In some cases, depending on the nature of the criminal activities, there are victims who could provide information on criminal earnings, which brings us to the second factor.

\section{The nature, logistics and scale of criminal operations}

Because of their consensual nature, crimes such as drug trafficking do not often produce victim reports. Non-consensual crimes such as human trafficking and extortion do (in some cases) produce victim reports, including information on, for example, how much money a trafficked prostitute was forced to hand over to her pimp.

Furthermore, the scale and logistics of the criminal business process influence whether or not certain types of information are found. It is very hard to engage in complex criminal operations, such as large-scale drug trafficking, for example, without any form of administration. ' $\mathrm{T}$ ' in the previous example was active on several links of the business process that constitutes international drug trafficking: production/supply, transport and sales. For each link, he had to manage and keep track of contacts, financial transactions and agreements, often with different partners. Beyond a certain scale and complexity of

135 In the case examples used in this chapter, all initials and numbers have been adjusted to make the people involved less easily identifiable. 
operations, human memory alone is simply not adequate. Therefore, some bookkeeping is found in several cases of, for example, drug trafficking and underground banking. Although in many cases the 'bookkeeping' consists of nothing more than notes on a piece of paper, once found it can prove very helpful in creating a picture of the (financial scope of) criminal activities.

\section{Use of legal economic infrastructure}

The legal economic infrastructure provides criminals with all sort of opportunities but using them is not without risks. In several fraud cases, the use of legal companies forms an essential part of the modus operandi. In case 142, for example, offenders use an investment company to attract money from unsuspecting customers who are tempted to participate in a promising investment project that, in fact, is nothing more than a scam. To funnel the money away, the offenders use other legal enterprises. However, precisely because these criminals use legal companies, their activities leave traces that helped to reconstruct the money trail.

In other cases, offenders turn to legal enterprises to buy chemicals or pharmaceuticals needed for producing or adulterating drugs. In some cases, the records of the sales kept by these legal enterprises are used by the police to calculate the size of the criminals' turnover.

\section{Overtness as an operational necessity}

Operational circumstances may tempt even a vigilant offender to be more overt than he would want to be. Owing to the unregulated and hostile environment in which an offender operates, a lot can go wrong during a criminal transaction; for example, there is the constant risk of seizure, business partners may prove to be unfaithful, or partners simply misunderstand each other. Since the easiest and fastest way to solve operational problems is to contact partners directly, misunderstandings and unexpected obstacles may lead to an increase in communication (Kleemans et al., 2002: 55-56). This is illustrated by the following case. During a transaction, the amount of cocaine delivered turns out to be smaller than agreed. To solve the confusion, offenders call each other (numbers represent kilos of cocaine).

C: 'There has been a miscalculation. It will be 150 and 380 ; not $160 \ldots$,'

K: 'So 530 and not 540 .'

C: 'Make a calculation and call me.'

$\mathrm{K}:$ 'OK.' ...

C: ‘... They say it's 530 and E says it's 540. I have to find out what causes the confusion.' 'Meanwhile E calls $\mathrm{K}$ and asks if he can come over. Later $\mathrm{K}$ calls $\mathrm{B}$ and puts $\mathrm{E}$ on the line] ... 
B: 'OK. How much was dropped off? Because yesterday I also talked to them about ... 530 or 540 .'

E: 'No, it was 530.'

B: '530? Yes, OK, ...' (case 124).

Various types of information produced by the investigative efforts of the police (and other parties) are used by the public prosecutor to build his confiscation case. Since in many cases factual information is far from complete, the estimation of criminal profits is based in part on extrapolations and assumptions. Ultimately it is up to the court to decide if and to what extent it goes along with the prosecutor's estimation as well as the underlying facts, extrapolations and assumptions.

\subsection{Court procedures: from public prosecutor's claim to Supreme Court}

Table 1 shows the complete court procedures of 102 confiscation order cases. Attrition takes place in all phases of the court procedure. For the 102 cases, the initial public prosecutor's claims total $€ 61,928,210$. The decisions of the district court in these cases result in confiscation orders totalling $€ 46,352,957$, which reduces further to $€ 30,471,637$ after 63 cases have gone to the appeal court, and ultimately to $€ 27,463,899$, due to the outcome of 34 cases that also went to the Supreme Court. So, from the convicts' point of view, it 'pays' to appeal. In total, the final confiscation orders in the 102 cases amount to less than half of the initial claims.

Looking at individual cases, it turns out that 82 cases result in a final confiscation order that is lower than the initial claim. In 19 cases, the confiscation order equals the initial claim, and only 1 case shows a confiscation order with a higher amount than initially claimed. Attrition during the court procedures consists of three main elements, which will be discussed below. 
Table 1. Confiscating the profits of organized crime of 102 convicted offenders:

Court procedures (in euros).

\begin{tabular}{|c|c|c|c|c|c|c|}
\hline & $\begin{array}{l}\text { District court } \\
\text { Public prosecutor's } \\
\text { claim }\end{array}$ & $\begin{array}{l}\text { Court's } \\
\text { order }\end{array}$ & $\begin{array}{l}\text { Appeal court } \\
\text { Public } \\
\text { prosecutor's } \\
\text { claim }\end{array}$ & $\begin{array}{l}\text { Court's } \\
\text { order }\end{array}$ & $\begin{array}{l}\text { Supreme } \\
\text { Court }\end{array}$ & $\begin{array}{l}\text { Final } \\
\text { confiscation order }\end{array}$ \\
\hline Court procedures & & & & & & \\
\hline$D C(N=39)$ & $4,703,962$ & $2,185,719$ & & $(2,185,719)$ & $(2,185,719)$ & $2,185,719$ \\
\hline $\begin{array}{l}D C+A C \\
(N=29)\end{array}$ & $22,309,844$ & $17,183,864$ & $12,113,334$ & $8,649,631$ & $(8,649,631)$ & $8,649,631$ \\
\hline $\begin{array}{l}\mathrm{DC}+\mathrm{AC}+\mathrm{SC} \\
(\mathrm{N}=34)\end{array}$ & $34,914,404$ & $26,983,374$ & $32,862,352$ & $19,636,287$ & $16,628,549$ & $16,628,549$ \\
\hline $\begin{array}{l}\text { Total } \\
(\mathrm{N}=102)\end{array}$ & $61,928,210$ & $46,352,957$ & & $30,471,637$ & $27,463,899$ & $27,463,899$ \\
\hline
\end{tabular}

Note: $\mathrm{DC}=$ district court, $\mathrm{AC}=$ appeal court, $\mathrm{SC}=$ Supreme Court.

\subsubsection{Court procedures: determining the amount of criminal profit}

Determining the profits of crime is more complex than follow-the-money rhetoric implies. Measuring revenues of hidden activities is difficult. Since factual information is limited, a public prosecutor has to rely on extrapolations and assumptions. Furthermore, how the amount of criminal profit should be established is not subject to strict definitions. So, different actors may use different methods and assumptions in their estimations (see also Bullock, 2014: 59-61). This produces a huge potential for disagreement, and this is exactly what becomes evident in our research. The investigated cases show a lot of disagreement - or different views - on what an offender made from his crimes. This disagreement may occur between the public prosecutor and the court, between the district court and the appeal court, or within the prosecution service itself.

In 77 of 83 cases in which the final recovery order diverges from the initial claim, court files provide information on the criminal profit as determined by the court. In 75 of those 77 cases the court disagreed with the criminal profit as estimated by the public prosecutor (in several cases the court also had other reasons to diverge from the prosecutor's claim; see following sections) (see also Meloen et al., 2003: 14, 171; Vruggink, 2001: 85).

In several cases, the court refuses to include profits made from criminal activities of which the defendant is not convicted and/or profits that, according to the court, are not based on solid and verifiable arguments. The case below is an example. 
$\mathrm{G}$ operates as the supplier in an international XTC-trafficking network. The public prosecutor puts a claim to the district court for a confiscation order of more than $€ 1,700,000$. The district court decides that a much smaller amount is appropriate, $€ 123,000$. The main reason is that the district court does not take into account two XTC transports for which $\mathrm{G}$ was not convicted but for which the prosecutor claimed there were sufficient indicators for his involvement. For the appeal court, the prosecutor claims a confiscation order of less than $€ 320,000$. However, in its estimation of the criminal profit $\mathrm{G}$ made, the appeal court includes even fewer XTC transports than the district court did, and it issues an order of less than $€ 100,000$, which, three years after the case has been transferred to CJIB for execution, G has paid (case 89).

In the following case, the appeal court disagrees with the prosecutor not so much on specific transactions, but rather on the average intensity of drug trafficking operations. Besides that, the appeal court also applied a reduction to the confiscation order.

The appeal court calculates the criminal profit of $\mathrm{F}$, a key player in a drug trafficking network, to be $€ 584,000$, almost $€ 250,000$ less than the calculation of the public prosecutor. Compared to the prosecutor, the appeal court assumes that the drug trade was less intensive - 4 kilos of cocaine per month instead of 6 - because $\mathrm{F}$ was imprisoned during a specific period, he intended to 'lie low' for a while, and because a fellow offender's death decreased trading opportunities. Furthermore, the court deducts $€ 420,000$ due to personal circumstances, as $\mathrm{F}$ is on welfare and under treatment for drug abuse. The final order boils down to $€ 164,000$, of which 11 years later F has paid less than $€ 60,000$ (case 17).

In several cases, it is not the criminal activities (alone) that are disputed, but (also) the net profits. This may concern criminal 'business costs'. Although judicial practice is rather strict regarding the deduction of costs, in some cases the court deducts more business costs than the prosecutor allows for in his estimation. This is the case, for example, in case 97, in which the prosecutor did not deduct the cost price of cocaine but the appeal court did. A dispute over the net profits may also concern the share of the estimated total profit ascribed to a convict. A court may conclude, for example, that net profits are smaller because it splits the total criminal profit among co-offenders or because it decides that the convict played a smaller part than the prosecutor assumed. 
$\mathrm{P}$ is the main offender in an extortion case. The public prosecutor puts a claim to the district court for a confiscation order of $€ 1,974,000$. The district court decides that confiscation should amount to $€ 1,709,000$, which equals the claim of the public prosecutor for the appeal court. The appeal court, however, issues a confiscation order of $€ 965,000$. Most of the difference is explained by the fact that the appeal court assumes that more than $€ 630,000$ of the extortion scheme was received by somebody other than P. More than five years after the execution of the order started, $\mathrm{P}$ has paid $€ 52,000$ (case 120).

As we have said, disagreement on the estimation of criminal profit not only occurs between court and prosecution, but also within the prosecution service. This may concern a difference between the prosecutor in the appeal phase and the prosecutor who brought the case to the district court. It also happens, however, that within one and the same phase the prosecutor changes his initial claim. Court files indicated that the latter occurred in at least 23 cases. ${ }^{136}$

The existence of diverging views is not a bad thing in itself. It is the reason a constitutional state provides the possibility to go to the appeal court. However, the level of disagreement does show that, at least in our sample, it is not quite clear how 'criminal profit' should be determined; what should and should not be understood as criminal profit, what information should be used to measure it, and how should different sources of information be weighted?

\subsubsection{Court procedures: lengthy procedures}

Another reason for attrition during the confiscation order procedure concerns reductions in the amount of the confiscation order due to violations of Article 6 of the European Convention on Human Rights (ECHR). In 21 of the 102 cases, the court decided that the confiscation court procedure exceeded the 'reasonable time' within which trials should take place according to the ECHR. As a result, the court applied a reduction to the confiscation order, varying from less than 1 percent up to 50 percent $(N=20$, missing data for one case).

Since the confiscation procedure is separated from the criminal law case, and both types of cases include the possibility to go to the appeal court and the Supreme Court, getting a final court decision on confiscation indeed takes time (see also Van Duyne et al., 2014; Vettori, 2006: 115). For half of the cases in our sample it takes at least 2.5 years to get from a decision of the district court in the criminal law case to a final confiscation order that is transferred to CJIB for execution; in a quarter of the cases it takes more than 4.5 years

136 The actual number of cases in which the prosecutor changed his claim could be greater, since court files may not always include information on this matter. 
( $N=82$, missing data for 20 cases). Looking at the data, there seem to be some incentives for offenders to extend the court procedure: an appeal, at least in our sample, is likely to result in a lower confiscation order, and, as we just noted, beyond a certain point protracted procedures may result in a reduction.

\subsubsection{Court procedures: taking into account the convict's financial capacity}

Finally, in nine cases the court decides to apply a reduction because of the limited financial capacity or other personal circumstances of the convict (for example case 17, as illustrated in a previous section). The reduction varies from 13 percent to 83 percent of the estimated criminal profit. Although the court applies a reduction in nine cases, more often requests for a reduction on grounds of insufficient financial capacity are rejected by the courts. ${ }^{137}$

\subsection{The collection of confiscation orders: What do they actually pay?}

After both the conviction in the underlying criminal law case and the court's decision regarding the confiscation order have become final, the confiscation order is transferred to CJIB for execution. To what extent are the final confiscation orders actually paid? Figure 1 provides the complete picture, from the prosecutor's claim up to and including the collection of confiscation orders. The information is up to date to 3 July 2015. On that day, 76 cases were considered as closed; in 26 cases the collection was still ongoing.

The average amount of the final confiscation order in our sample is $€ 269,254$; with a minimum of less than $€ 100$ and a maximum of more than $€ 6,000,000$. The distribution is very skewed: there are relatively many 'small' and few 'large' confiscation orders (see also Bullock et al., 2009: 7-9; Fleming, 2008: 75, 78; Van Duyne et al., 2014). Half of the confiscation orders amount to less than $€ 35,000$ and a quarter exceed $€ 100,000$. The final confiscation orders total $€ 27,463,899$. Up to 3 July $2015, € 11,325,036$ has been paid, which represents 41 percent. ${ }^{138}$ Before we look into the factors causing attrition during the collection of confiscation orders, it should be mentioned that, since the collection has not yet come to an end in 26 cases, eventually the percentage of the confiscation amount actually paid can and probably will go up. However, there are two reasons why expectations of this potential increase should be tempered. First, the collection of those confiscation

137 The overview of reasons for attrition during the court procedures includes the most prominent results of our analyses of the court files, but it is not extensive. Furthermore, some court files did not include adequate information on the court's motivation.

138 The payment rate decreases as the value of confiscation orders increases. For cases in which the order amount is lower than $€ 15,000,83$ percent of the total sum is paid $(\mathrm{N}=28)$. For cases with an order value of $€ 15,000-35,000$, $€ 35,000-100,000$, and $>€ 100,000$, the percentage drops to 78 percent $(\mathrm{N}=24), 64$ percent $(\mathrm{N}=25)$, and 39 percent $(\mathrm{N}=25)$ respectively (see also Bullock et al., 2009: 9-12). 
orders has already been running for many years (median $=8$ years) Second, if we look at cases that were transferred to CJIB for collection a long time ago, collection results do not improve dramatically. The collection percentage for all 102 cases together is 41 percent. For cases with a potential collection period of at least 7 years, the percentage is 38 percent $(N=88)$, whereas it is 52 percent $(N=60)$ for cases with a potential collection period of at least 11 years. This percentage is the same (52 percent) for cases with a potential collection period of at least 14 years $(N=38)$.

Figure 1. Confiscating the profits of organized crime of 102 convicted offenders: from public prosecutor's claim to collection.

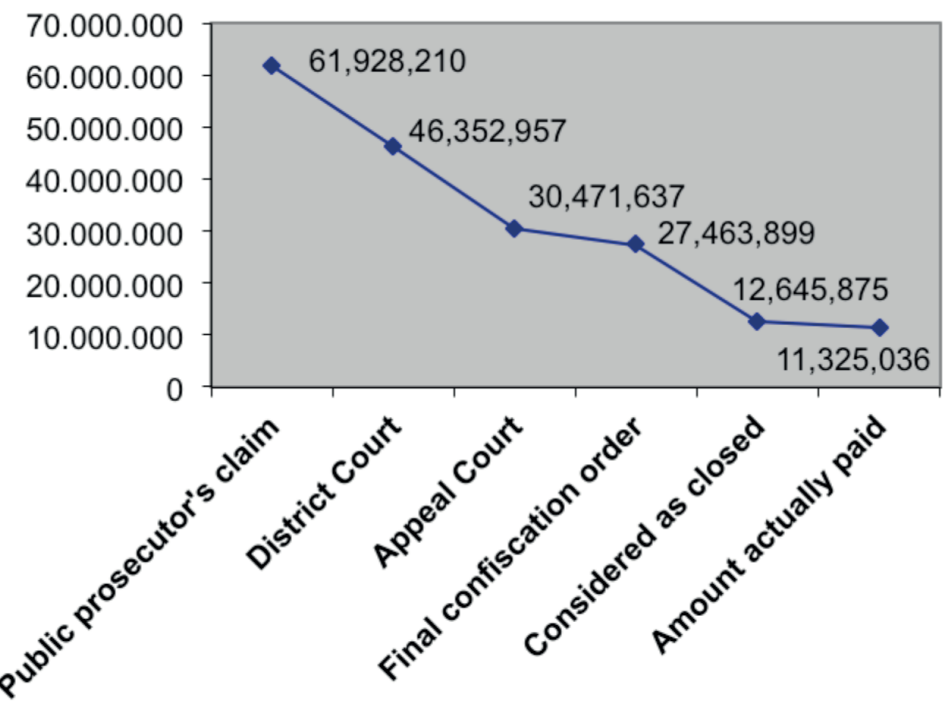

\subsubsection{Legal reasons to stop collection without (full) payment}

In 19 cases, there were legal reasons to stop collection without (full) payment. In nine cases, the court allowed for the (partial) remission of the imposed confiscation order, particularly when life circumstances of the convict worsened. Eight convicts who did not pay got 'replacement custody'. ${ }^{139}$ Furthermore, collection was precluded by reason of the lapse of time in three cases, two convicts had died before the confiscation order was fully paid, and in two cases there were 'other' reasons. Together these reasons account for $€ 1,320,839$ that was considered as 'closed' although it was not paid. So there must be other and more important reasons why $€ 16,138,863$ (59 percent of the total sum of the final

139 Replacement custody is only possible if the confiscation order became irrevocable before 1 September 2003. 
confiscation orders) remains unpaid (until now). Those other reasons boil down to convicts successfully hiding their assets from law enforcement agencies and/or convicts who are simply unable to pay. Looking at the legislation and the court procedures, as well as the literature on organized crime and financial investigation, these two main reasons can be specified as follows.

\subsubsection{Convict is unwilling to pay and succeeds in hiding his assets}

A very simple reason money is not collected boils down to convicts covering their assets and law enforcement agencies failing to trace those assets. The police might have good reasons to believe that an offender has assets, but there may be no actual signs of them (Bullock et al., 2009: 14-19; Fleming, 2008: 86-89). Furthermore, law enforcement agencies are hindered by the fact that part of an offender's assets are located abroad. Our analysis of the assets of organized crime offenders in the Netherlands has shown that more than onethird of the real estate and companies owned by them was located in a foreign country, for example in their country of origin (chapter 4). Investigating and especially confiscating the profits of crime within a country is difficult as it is; cross-border confiscation is even more difficult (Brown and Gillespie, 2015; Cabana, 2014: 19-21; Levi, 2013: 1).

Whether nationally or internationally, it all comes down to the police and other law enforcement officers focusing on 'following the money'. As Van Duyne et al. (2001: 89-94) argue, a financial investigation is partially a mental attitude, a way of looking at things that can be integrated into the daily routines of police work. Bullock $(2010: 8,12,13)$ found that financial investigations have not yet become an established part of daily policing in England and Wales. Vettori reached comparable conclusions in an EU-wide study (Vettori, 2006). Similar results were found by the Swedish National Council for Crime Prevention (Brå, 2008: 23) and, for the Netherlands, by Meloen et al. (2003: 23-24) and the Inspectie Openbare Orde en Veiligheid (2012: 10). Although the Dutch Court of Audit (2014: 6-8) concluded that capacity and expertise have improved since 2008 , it is clear from the literature that the greater emphasis policymakers put on financial investigations does not automatically and immediately produce results in investigative practice.

\subsubsection{The convict is unable to pay}

Another part of the attrition is probably not a consequence of unwillingness to pay or any failings during the phases of investigation and collection, but rather a consequence of how criminal profits are defined in law and judicial practice (see also Bullock et al., 2009: 14-19; see also Vruggink, 2001). Costs, as mentioned before, are only deductible if they are directly linked to the criminal acts that generated the profit under consideration. In practice, this means that costs an offender paid when pursuing transaction $B$ can be ignored when deciding on a confiscation order that concerns only transaction A. In case 47, for example, the appeal court decided that the cost price of 130,000 pills that were seized 
before the offender could sell them should not be deducted since the confiscation order concerned only other, successful, sells. Whether or not the money has been spent is also not taken into account when criminal profit is estimated. Earlier studies show that a part of the money offenders make is spent on an exuberant consumption pattern, that is, nightlife, cars, jewellery, clothing, holidays, et cetera (for example, Fernández Steinko, 2012; Levi, 2012: 610; see also chapter 4). These expenditures are ignored, as are others. If an offender has given some of his money away, this does not change the fact that the money was made through crime, and so the offender should pay it 'back' to the state, as was decided by the appeal court in case 86 . Nor is it taken into account if the money has been spent or lost on other criminal activities, as is illustrated by the following case.

Several offenders reinvest their earnings in counterfeited clothing. The clothing, however, is seized. The appeal court decides that the money the offenders invested should not be deducted from the criminal profit. If you reinvest in criminal activities, the appeal court argues, you deliberately take the risk of seizure. The seizure of the clothing does not change the fact that the money the offenders invested concerns profit of prior criminal activities (case 68).

So what counts for the determination of the confiscation amount is the initial profit a convict made. Whether or not the money is spent on consumption or reinvestments may be ignored, as may any losses made in prior criminal activities. Some would say that this is in line with the basic thought that a criminal should not be allowed to enjoy any benefits from his deeds. It also means, however, that a part of the 'criminal profits' might never be recovered. ${ }^{140}$

\subsection{Conclusion and discussion}

\subsubsection{Empirical results}

This chapter gives empirical insight into financial investigations and asset recovery in organized crime cases in the Netherlands. We explored how certain characteristics of offenders and the criminal operations they engage in relate to the amount and type of information that investigators may find. Four factors appear to be relevant: offenders' and witnesses' behaviour, the logistics and scale of criminal operations, the use of legal economic infrastructure, and operational necessities that may force offenders to expose themselves.

140 In the U.K. post-conviction confiscation regime, a distinction is made between 'criminal benefit', that is, the amount a defendant is adjudged to have made from criminal activities, and the 'available amount', that is, the amount that the state deems to be actually available for confiscation. However, this does not mean that the collection of confiscation orders in the United Kingdom is free from attrition (Bullock, 2014; Bullock et al., 2009). 
The information produced by investigative efforts of law enforcement agencies is used by the public prosecutor to build a confiscation case. We gave a complete picture of the confiscation order court procedures as well as the collection of those orders for 102 convicted offenders. Attrition takes place in all phases. For 102 cases, the initial public prosecutor's claims total $€ 61,928,210$. At the end of the court procedure, this is reduced to $€ 27,463,899$ (44 percent), of which $€ 11,325,036$ (41 percent) is paid (July 2015).

\subsubsection{Explaining attrition}

Summing up, attrition is substantial, both during the court procedures and during the collection of confiscation orders. Our results indicate that a fundamental factor causing attrition during the court procedures concerns the lack of clarity surrounding the determination of 'criminal profit'. The legislator created a lot of room for discretion, as there is no strict definition of 'criminal profit', nor of how it should be estimated. Combined with the fact that solid data on criminal earnings are by definition limited, this creates a huge potential for different views on actual criminal profits. At least in our sample, this potential is fully realized. In a majority of cases, the court does not agree with the criminal profit estimated by the prosecutor and decides that a (much) smaller confiscation sum is appropriate. How 'criminal profit' is defined in law and judicial practice probably also plays an important role as regards attrition taking place during the collection of confiscation orders. Spending behaviour and losses during criminal transactions are partially ignored when estimating the amount of money an offender should pay. Ignoring expenditures and losses may be well justified given the ideological position that 'crime should not pay'. However, it also increases the chance that offenders are simply not able to pay the confiscation amount in full.

Another factor causing attrition boils down to a problem that all follow-the-money initiatives suffer from: sensible offenders hide their assets and law enforcement agencies do not succeed in tracing them all. Tracing and seizing assets is further complicated by the fact that part of offenders' assets are located abroad.

Furthermore, confiscation procedures take a lot of time. In some cases, the court applies a reduction to the confiscation order because the procedure exceeded the 'reasonable time' within which trials should take place.

Finally, in some cases, the court decided that the financial capacity of the convict justified a lower confiscation amount, or there were legal reasons to stop collection before a confiscation order was paid in full.

\subsubsection{Implications}

Our sample consists of 102 cases of organized crime with a confiscation order. We do not know whether or not these cases are representative of all cases of organized crime in which confiscation orders were used (see chapter 6). Furthermore, the sample does 
not include cases in which financial investigation failed to sustain an application for a confiscation order. However, this chapter represents one of the few studies that empirically examines both financial investigations and confiscation order court procedures as well as the collection of those confiscation orders. Because of the scope of the study as well as the qualitative interpretation of the numbers we delivered, the study contributes to bridging the knowledge gap concerning the practice and results of 'follow the money'.

Our results show that how 'criminal profit' is determined in law and practice is probably an important cause for attrition. This emphasizes the need for more insight into "the law in action'. More empirical knowledge should enhance the legislative debate on the content as well as the necessity and usefulness of new legislation. It should also help to have a kind of 'reality check' of the high expectations that are prominent in the debate. Advocates of 'follow the money' often emphasize that financial investigations 'pay for themselves', and more. Whether this is the case is questionable, as research in the United Kingdom indicates (Bullock, 2014: 63; Collins and King, 2013; Levi, 2013: 10; Sproat, 2009).

The value of financial investigations, in a broad sense, should be one of the topics of interest for further research. A financial investigation is much more than a means to recover assets. It can, among others, help identify new suspects, provide information on suspects' movements, and give new insights into the role of different suspects (Brown et al., 2012: 5-9; Levi, 2013). If, to what extent, and how this potential is realized are some of the questions that need to be addressed.

As far as asset recovery itself is concerned, policymakers, as well as researchers, should recognize the distinction between measures and sanctions such as confiscation orders, fines, settlements out of court, and cash seizures. Their applicability as well as their possible costs and benefits differ. Our study focused on confiscation orders. Confiscation procedures are complicated and an 'uphill battle'. The fact that confiscation orders are not paid in full does not mean that they - let alone other measures - are not worthwhile. It is possible that the various policy measures, although the implementation is far from perfect, have some of the intended deterrent and preventive effects. The money that is taken away from offenders should at least have some impact on them. Further research should focus on the effects of different sanctions and measures (see also Collins and King, 2013; House of Commons, 2014: 11; Sproat, 2007: 183-184). How are offenders, the level and type of the criminal activities they engage in, and their modus operandi affected? Quantitative recidivism research as well as qualitative case studies (studying police files and interviewing offenders) could shed some light on these matters (e.g. Vruggink, 2001). ${ }^{141}$ Furthermore, our results indicate that further research should be done

141 Vruggink concluded from interviews with 100 imprisoned convicts (most of whom were convicted for drug trafficking, burglary and robbery) that the confiscation order has no significant influence on the decision to commit crimes (2001: 151). 
on the implementation of confiscation legislation. More insight into the decision making and problems that occur during the collection of confiscation orders, for example, should enhance our understanding of the results and could point to possibilities to improve them.

Policymakers are very productive where it concerns new legislation to enhance the possibilities for asset recovery. Debates concerning these reforms are often inspired by ideological standpoints, such as the notion that 'crime should not pay'. Our results show that determining the profits of crime is more complex than rhetoric might imply. Furthermore, recovering the profits that criminals are adjudged to have made proves to be very hard. It is not a bad thing if decision making in the political arena is based (in part) on ideology. However, legislative debates should be fuelled more by pragmatism and - above all - insight into the 'law in action'. A better understanding of how, against whom, and with what results different follow-the-money measures are applied might help to choose the 'right' objectives and priorities. It might also help to improve - or prevent - further legislative initiatives. 


\section{Conclusion and discussion}

Empirical research on organized crime policies is scarce. The aim of this thesis is to contribute to the empirical evidence by giving insight into the practice and results of two counterstrategies to organized crime in the Netherlands: the criminal justice approach and the financial approach. In chapters 2 and 3, we presented empirical evidence on a specific method of criminal investigation: undercover policing. Chapters 4 and 5 centred on the financial approach; chapter 4 looked into what organized crime offenders actually do with their money and chapter 5 analysed the efforts of law enforcement agencies to confiscate criminal earnings. In this final chapter, we will summarize the main empirical results (section 6.1), we will discuss the methodological strengths as well as the weaknesses (section 6.2), we will explore the possible implications of our results for organized crime policies (section 6.3), and we will make suggestions for further research (section 6.4).

\subsection{This thesis: research questions, data and summary of the empirical results}

\subsubsection{The criminal justice approach}

For the criminal justice approach, we focus on undercover policing. Undercover policing is one of the most controversial policing methods. Furthermore, undercover operations lay at the heart of the IRT affair (see chapter 1), which defined the course of the legislative debate. Both the first and the second sets of research questions of this thesis relate to the use of undercover police officers (the use of civilians in undercover operations is not included).

\section{Undercover policing: general overview of undercover operations in 2004}

The first set of research questions focuses on undercover policing in general, i.e. on Dutch criminal investigations in 2004 in which an undercover operation was considered:

- How often are undercover operations deployed?

- What different types of undercover operations exist?

- What results have these operations produced?

These research questions are addressed (chapter 2) by using various data sources. From specialized police undercover units, we retrieved information with regard to Dutch criminal 
investigations in 2004 during which these units were consulted and in which the deployment of an undercover operation was considered. ${ }^{142}$ Furthermore, for all criminal investigations in which an undercover operation was actually deployed, we interviewed (by telephone) the public prosecutor and/or the detective in charge of the criminal investigation. Finally, we examined Dutch case law regarding undercover operations.

In 2004, the deployment of an undercover operation was considered in 89 Dutch criminal investigations. ${ }^{143}$ In 52 cases, it was eventually decided that such an operation was not possible or unnecessary. In 37 cases, it was decided to set up an undercover operation, yet in 3 of these cases, the operation was abandoned even before the start. Thus, in 34 cases, one or more undercover agents were actually deployed. By way of comparison: in 2008, 26,425 Dutch telephone numbers were tapped (Tweede Kamer, 2008-2009, 30 517, no. 13). So, at least in the period we studied, undercover policing is not often applied. One reason may be that especially the more controversial forms of undercover operations (infiltration) are mainly used when other investigative instruments have failed, although legislation does not prescribe that undercover operations in general are only to be used as a last resort. Other possible reasons are: a lack of need for a more frequent use (due to the use of other methods); a limited knowledge of and experience with undercover operations at the Public Prosecution Service and in the police force; a reluctance to use undercover operations due to the IRT affair and its aftermath; and a reluctance to opt for this method because of the required authorization procedures, especially in the case of infiltration (see the following section).

Undercover operations vary greatly with regard to their duration, intensity and the sort of contact between the undercover agent and the subject (chapter 2). Some undercover operations consist of no more than a brief business contact with a suspect and only take a day. However, an undercover operation may also last more than a year, encompassing many meetings between undercover agent and suspect. The nature of the contacts varies as well. Contacts may be mainly businesslike, such as in many investigations targeting drugs or weapons. Yet, in cases in which an undercover agent befriends a suspect in order to get information about his involvement in a seriously violent crime, for example the murder of his wife, the undercover agent sometimes has to establish a quite intensive personal and emotional bond with the suspect.

142 Undercover operations within the context of international legal assistance were not included.

143 We retrieved information from the five specialized undercover units with regard to all 37 criminal investigations in 2004 during which an undercover unit was consulted and in which it was decided to deploy an undercover operation. Four of the five undercover units could also produce information with regard to 46 investigations in which the consultation ended in a decision not to deploy an undercover operation. Assuming that the ratio of positive decisions to negative decisions for these four units is also valid for the fifth unit, the total number of negative decisions comes down to 52, which brings the total number of criminal investigations in which an undercover unit was consulted to $(37+52=) 89$ (see chapter 1$)$. 
Furthermore, we looked into how many and what sort of results undercover operations generate. In 7 of the 34 cases, the undercover operation generated evidence that has been used in convicting one or more suspects (inclusion); in 4 cases, the investigation team decided based on the information gathered by the undercover agent(s), that the suspicion against a suspect was (partly) untrue (exclusion), in 1 case, the undercover operation resulted 'only' in steering information; and in 22 cases, the operation did not contribute anything to the investigation or trial (see chapter 2).

Besides contributions made by undercover operations to investigations and trials, the 'legal tenability' of this instrument might also be understood as a 'result'. To find out how judges respond to pleas put forward by the defence regarding undercover operations, we studied more than 60 court decisions. In these court cases, the defence argued, for example, that the undercover operations involved entrapment and/or that the operations were incompatible with the principles of proportionality and/or subsidiarity. It turned out that the vast majority of these pleas was dismissed by the judges. Transparency seems to be of great importance in this context, i.e. the extent to which the police and the Public Prosecution Service provide insight into the decision to use an undercover operation, its actual deployment, and the findings the operation has generated. In the great majority of cases, the information provided to the judges convinced them of the legitimacy of the undercover operation. In the small number of cases in which judges accepted a plea, the reason has often been the inadequate reporting of and poor insight given into the undercover operation.

The most striking feature of the undercover operations we studied is the unpredictability of how the meetings between the undercover agent and the suspect, and thus the entire operation, will work out. This unpredictability manifests itself most clearly during operations involving undercover buys. During an undercover buy, an undercover agent poses as a fellow criminal, for example, who is interested in buying drugs or weapons. In undercover operations that target profit-motivated crime, such as the drug trade, an undercover agent often poses as a criminal 'entrepreneur' who is not averse to making a profit. Criminal 'entrepreneurship' suffers from (at least) three risks (cf. Reuter, 1983: 113-117): the unregulated nature of the environment in which offenders operate; the fact that the chain of the criminal 'business' process may be disturbed at any time by seizures and arrest; and the 'colleagues' of an offender, i.e. his fellow offenders, who might turn out to be untrustworthy or incompetent. Because the undercover agent acts on the criminal market, he has to deal with the unreliable and unpredictable behaviour common to that market. Most of the undercover buys in the cases we studied did not work out according to plan. Either an undercover buy did not take place at all, e.g. because the suspect in the end turned out to be unable to deliver, or the undercover buy did take place but the suspect delivered less than initially agreed. Unexpected developments such as these do not necessarily mean that the undercover operation fails entirely but, in general, they do cause operations to last longer or to fail in getting the intended results. The great frequency with 
which commitments are not kept, trade qualifications turn out to be false or undercover buys do not meet the expectations in other ways, indicate that it is not easy to 'do business' with criminals efficiently.

This finding constitutes the flip side of an assumption present in academic discourses concerning undercover policing. Part of these discourses focuses on the manipulative nature of this method of investigation. This discourse centres on the undercover agent, who leads the suspect into a 'trap' and who, in the contact between both actors, is attributed an active, directive role, while the subject is (implicitly) attributed a passive, following role. It is certainly true that deception is an essential feature of undercover operations. However, the idea that the undercover agent is the one who completely dominates the course of the operation passes over the fact that, in many cases, the practical course taken by an operation is to a large extent determined by the unpredictable behaviour of other actors.

\section{Undercover policing: infiltration operations 2000-2005}

The Dutch code of criminal procedure distinguishes between three undercover police powers: systematic intelligence gathering; the purchase of illegal goods or substances or the rendering of illegal services (undercover buys); and infiltration (see chapter 1). Legally, infiltration is the most serious undercover power in the Dutch code of criminal procedure and is mainly deployed in organized crime cases. The undercover operations mentioned in the previous subsection all concerned systematic intelligence gathering and/or undercover buys; none of them concerned infiltration. To gain insight into the investigative practice of infiltration, which is the focus of the second set of research questions, we gathered information over the 2000-2005 period (chapter 3). The legal requirements as well as the authorization procedures with regard to the use of infiltration are stricter than they are with regard to the other two undercover powers. One of the research questions therefore specifically looks at how regulatory procedures work out in practice.

- How often are infiltration operations deployed?

- What results have these operations produced?

- What outcomes do the regulatory requirements produce in the investigative practice?

The data cover all infiltration operations in the Netherlands during the 2000-2005 period. A public prosecutor who wants to deploy an infiltration operation has to submit a proposal before the Central Assessment Committee (in Dutch: Centrale Toetsingscommissie (CTC)). If the CTC concludes that the operation is permissible, the proposal goes to the Board of Procurators General, where the ultimate decision is made about allowing the infiltration operation or not. For all Dutch criminal investigations in which an infiltration operation was proposed during the 2000-2005 period (and in which the infiltration operation was finalized at the time the research was conducted), we studied the files at the CTC and/or 
the actual police files (see chapter 3 ). ${ }^{144}$ The police files contain the results of all police activities deployed in a case, such as testimonies of undercover agents, reports of wiretaps, bugging and police observations, reports of interrogations of offenders and witnesses, and the results of financial investigation and seizures. In addition, we conducted face-to-face interviews with 35 people, 20 of whom were involved in the infiltration cases we studied. The other fifteen respondents were selected on grounds of their involvement in other cases in which undercover operations were used.

In the 2000-2005 period, approval to deploy an infiltration operation was requested in 23 Dutch criminal investigations. ${ }^{145}$ In sixteen cases, the Board of Prosecutors General authorized the use of infiltration. However, only in fourteen cases, the infiltration operation was actually deployed.

In six of those fourteen cases, the infiltration operation produced evidence on the (partial) basis of which suspects were convicted. Four operations 'only' generated steering and/or residual information (see chapter 3). The remaining four operations did not contribute to the investigation or trial at all. ${ }^{146}$ In the previous subsection, we described the unpredictable course of undercover operations, especially those focusing on bringing about one or more undercover buys. The course of infiltration operations proves to be equally or even more erratic. Of the thirteen infiltration operations in which the undercover agent actually established contact with the targets, twelve focused on bringing about one or more undercover buys, among other things. None of these worked out as planned.

Besides the infiltration operations as such, we also looked into how the regulatory procedures worked out in practice. We focused on features of the regulatory framework that do not always fit the investigative practice.

The Dutch legislator, as mentioned earlier, distinguishes between three types of undercover powers: systematic intelligence gathering, undercover buys and infiltration. Infiltration is assumed to be more risky than the deployment of an undercover buy, which, in turn, is assumed to be more risky than systematic intelligence gathering. The legal requirements for the deployment of the undercover powers differ accordingly; the legal

144 Infiltration operations within the context of international legal assistance were not included.

145 In fact, during the 2000-2005 period, authorization for an infiltration operation was requested in 24 investigations However, one case was not included because the infiltration operation was still ongoing at the time the research was conducted.

146 The results of infiltration operations, i.e. their contribution to investigations and trials, should not be compared in quantitative terms with the results of systematic information gathering and undercover buys. First, although the Dutch Code of Criminal Justice clearly distinguishes between the three undercover powers, in their actual deployment, the distinction is not always as clear. Second, several infiltration operations we studied included the preceding deployment of systematic information, and in most infiltration operations, undercover buys were deployed (or planned) as well. Third, systematic information gathering and undercover buys may be deployed in investigations targeting only one suspect, whereas infiltration is always deployed in the context of a criminal group, which increases the chance that the operation will yield evidence or other relevant information with regard to at least one suspect. 
conditions stipulated for infiltration are stricter than those stipulated for undercover buys, while the conditions for this latter power are stricter than those for systematic intelligence gathering. In the investigative practice, however, the application of systematic intelligence gathering can prove to be more invasive than infiltration is (Beijer et al., 2004: 103-104). The reason for this is that in some cases of systematic intelligence gathering, for instance when an undercover agent is deployed to find out whether a man has killed his wife, the undercover agent needs to get very close to a suspect, he has to see to it that the suspect trusts him personally, like a friend, in order to get him to talk. Building such a friendly relationship, and subsequently betraying this 'friendship', may be more psychologically taxing to an undercover agent (and the subject) than playing the role of a criminal entrepreneur in a drugs investigation, such as is the case in several infiltration operations.

Furthermore, the centralized authorization procedures that apply to infiltration may produce unwanted outcomes. A public prosecutor who wants to deploy an infiltration operation has to comply with several authorization requirements. Ultimately, he has to get the approval of the highest level of authorization within the Public Prosecution Service, the Board of Prosecutors General, an approval which, if granted, has to be renewed on a regular basis. Some public prosecutors may fear that they will lose control if they choose to use infiltration. Because of this fear, or 'interference aversion', they might avoid this investigative method or choose to use a combination of systematic intelligence gathering and undercover buys, in which case approval of the Board of Prosecutors General is not required (see also Beijer et al., 2004: 109).

Finally, to test in advance for subsidiarity, clashes to a certain extent with the fundamental unpredictability that characterizes investigations into organized crime. When testing a proposed infiltration operation for subsidiarity, the Board of Prosecutors General has to judge whether it is likely that the goals of the criminal investigation can be achieved by deploying other policing methods. The test for subsidiarity has a retrospective as well as a prospective element, the latter of which means assessing the probability that other methods than infiltration will produce any decisive results in the weeks and months to come. However, criminal investigations into organized crime are unpredictable due to the erratic behaviour of criminals, the relatively large number of suspects included in an average organized crime case, as well as the fact that, usually, different policing methods are deployed simultaneously. In several cases in which the Board of Prosecutors General authorized an infiltration operation, it turned out that, after the authorization was given, other methods of investigation did in fact generate decisive results, although they were deemed ineffective.

\subsubsection{The Financial approach}

The third and fourth sets of research questions concern the financial approach to organized crime. The financial approach consists of two main parts: anti-money laundering measures, 
which aim at criminalizing the handling of 'dirty' money and preventing criminals from using the legal financial and economic infrastructure; and confiscation laws, which aim at taking away criminals' assets (Gallant, 2005: 11).

\section{Investments of organized crime offenders in the legal economy}

The third set of research questions focuses on what organized crime offenders actually do with their money (chapter 4). The main point of interest concerns offenders' investments in the legal economy, because these kinds of investments seem to be the most important reason for concern among policymakers.

- What do offenders in organized crime invest their money in?

- Where do they invest their money?

- What can be inferred from offenders' investments about underlying strategies and motives?

The empirical data consist of cases from the Dutch Organized Crime Monitor. The Dutch Organized Crime Monitor is an ongoing research project on the nature of organized crime in the Netherlands. In four data sweeps, during the 1996-2011 period, 150 criminal investigations were analysed, covering a broad range of types of organized crime. For each case, the police files are extensively analysed and a case report is written. To answer this third set of research questions, all 150 case reports were checked for available information on offenders' assets. For 124 of the 150 cases, information was available on investments in real estate objects and/or companies in the Netherlands or another country. These 124 cases account for a total of 1,196 individual assets.

The real estate investments of offenders in cases of drug trafficking, human smuggling/ trafficking and illegal arms trade consist in large part of residences. This involves houses and flats, varying from modest dwellings to very roomy and luxurious villas, used by the offenders themselves or their relatives, but also houses and flats rented out to others.

The companies these offenders invest in frequently concern wholesale and retail businesses (for example fruit importing companies, shops), hotels and restaurants, transportation companies, brothels, and 'management' or 'investment companies, the main purpose of which is to hold other assets (real estate, for example). Some cases of fraud and money laundering show a different pattern. Among such criminals' real estate 'portfolio', we more frequently find commercial real estate. The companies they own are more often real estate companies or the aforementioned 'management/investment' companies. In general, investments in the sectors agriculture and fishing, mining, manufacturing and energy are absent or strongly underrepresented. For more than half of the companies offenders invest in, the case reports we studied include information indicating that the company is used for criminal activities, i.e. for money laundering purposes, logistics, and/or legitimization. 
With regard to companies offenders invest in, in many cases the offender is somehow personally involved, i.e. an offender (partially) controls the company directly or indirectly, and the company is used for criminal purposes and/or actual economic activity takes place on behalf of the offender. Offenders do not frequently invest in purely financial assets, i.e. bonds, options and stocks in companies in which offenders are not somehow personally involved, such as stocks in companies noted on the stock exchange. Those assets were found in only a small number of cases.

As far as the place of investment is concerned, offenders predominantly invest in their 'home country' ( $82 \%$ of individual investments). This 'home country' can be an offender's country of origin, i.e. the Netherlands for indigenous Dutch offenders, Turkey for offenders originating from Turkey, et cetera, or his country of residence, i.e. the Netherlands for offenders originating from Turkey but living in the Netherlands, et cetera. Looking at specific countries where offenders invest, $64 \%$ of all assets is located in the Netherlands, while $36 \%$ is located in other countries.

We used the results to post-hoc evaluate the tenability of different theoretical perspectives and assumptions that are present in the literature on organized crime and investments in the licit economy. One such perspective is the standard economic approach. It assumes that offenders make cost/benefit efficient investments in a globalized economy. Profitability is assumed to be the main determining factor and offenders are assumed to be very flexible when it comes to switching between countries or economic sectors. However, the geographical scope of offenders' investment portfolios turns out to be rather limited, since most investments are located in the offenders' home country. Furthermore, in particular in cases of drug trafficking, human smuggling/trafficking and illegal arms trade, offenders mainly invest in houses and other real estate (which limits the ability to swiftly withdraw money and move it to another country), as well as in companies they are familiar with from everyday life (retail, hotels, restaurants et cetera), which are used in many cases for criminal purposes. Investments in purely financial assets, on the other hand, were found in only a small number of cases. These results indicate that the standard economic approach is probably not the most adequate perspective to describe and understand the investment choices of organized crime offenders.

Nor does the criminal infiltration approach fit our empirical results. This perspective emphasizes that investing in the licit economy brings power and influence to offenders. However, no examples were found of investments that would allow offenders to reach for powerful legitimate positions in the Netherlands from the 'underworld', at least not on a national level. We did find a small number of offenders with very well established positions in the licit economy, but (some of) these are illustrations of, one might say, 'infiltration the other way around'; 'legitimate' businessmen and professionals without a criminal record who utilize their position in the licit economy to set up criminal activities. 
Instead of profitability (the standard economic approach) or power (the infiltration approach), proximity seems to be a better suited label to describe the investments of the offenders we studied. After all, the results showed that the distance between the offender and his assets is often small, comprising both physical and social distance. This 'proximity' fits pretty well with the social opportunity approach regarding organized crime. Kleemans and De Poot (2008) used the term 'social opportunity structure' to explain involvement in organized crime: criminal opportunities depend on social ties, which in turn depend on one's age, social, geographical and ethnic background, occupation, et cetera. This social opportunity structure also proves to be useful to understand the choices offenders make when they invest the profits of crime: their options for investment are defined and limited by the opportunities offenders find in their direct social environment.

\section{Investigating and confiscating the profits of organized crime}

The fourth set of research questions focuses on the efforts of law enforcement agencies to confiscate criminal earnings (chapter 5). It looks into one specific instrument to take away offenders' money: the confiscation order. The empirical data consist of cases from the Dutch Organized Crime Monitor, confiscation order court files, and data from the Central Fine Collection Agency (CJIB), responsible for the execution of confiscation orders. Together, the data sources shed light on financial investigation in practice and give a complete picture of the confiscation order court procedures as well as the execution of those orders for 102 convicted offenders. Furthermore, they provide insight into the problem of attrition, i.e. the gap between estimated criminal profits on the one hand and the actually recovered assets on the other. Two research questions are addressed:

- How do the investigation and confiscation of criminal profits work out in organized crime cases?

- What explanations can be offered for the phenomenon of attrition?

With regard to the 102 convicted offenders for which we were able to provide a complete picture of the confiscation order court procedures as well as the collection of those orders, the initial public prosecutor's claims total $€ 61,928,210$. At the end of the court procedure, this amount has been reduced to $€ 27,463,899$ (44 percent), of which, until July $2015, € 11,325,036$ (41 percent of $€ 27,463,899 ; 18$ percent of $€ 61,928,210$ ) has been paid (in 26 cases the collection was still ongoing).

So, attrition is substantial, both during the court procedures and during the collection of confiscation orders. An important factor with regard to this attrition is how 'criminal profit' is defined (determined) in law and practice. There is no strict legal definition of what constitutes 'criminal profit' or how it should be estimated. Furthermore, solid data on criminal earnings are by definition limited. This creates a huge potential for different views 
on actual criminal profits. In a majority of the cases we studied, the court did not agree with the criminal profit estimated by the prosecutor and decided that a (much) smaller confiscation sum was appropriate. How 'criminal profit' is defined in law and practice probably also plays an important role with regard to attrition taking place during the collection of confiscation orders. Spending behaviour of an offender and losses during criminal transactions are partially ignored when estimating the amount of money he should pay. This may be well justified on legal and ideological grounds, but it also increases the chance that offenders are unable to pay the confiscation amount in full.

Another, obvious factor causing attrition boils down to a problem all follow-themoney initiatives suffer from: the fact that (sensible) offenders hide their assets, sometimes abroad, and law enforcement agencies simply do not succeed in tracing them all.

Furthermore, in some cases, the court applies a reduction to the confiscation order because the procedure has exceeded the 'reasonable time' within which trials should take place. Also, in some cases, the court decided that the financial capacity of the convict justified a lower confiscation amount, or there were legal reasons to stop collecting before a confiscation order was paid in full.

\subsection{Scope of this research and methodological considerations}

This thesis focuses on counterstrategies to organized crime. Our aim is to give insight into partly hidden instruments (undercover operations) that are deployed against persons who, in turn, probably do everything they can to stay out of sight. This limits the possibilities for a researcher by definition. Methods chosen and data used always have limitations, and this is even more so in the case of research on the fight against a hidden phenomenon such as organized crime. In this section, we will elaborate on the limitations as well as the strengths of the research design.

\subsubsection{Scope and limitations}

\section{Undercover policing}

Our study on undercover policing is one of the very few that gives empirical insight into the investigative practice as well as the results of this policing method. Furthermore, the data collection that took place for this study is comprehensive. We gathered information for all 89 undercover operations that were considered in one year, 2004 (chapter 2). ${ }^{147}$

147 From the five specialized undercover units, information was retrieved with regard to all 37 criminal investigations in 2004 during which an undercover unit was consulted and in which the decision was made to deploy an undercover operation. Four of the five undercover units could also produce information with regard to 46 investigations in which the consultation ended in a decision not to deploy an undercover operation. Assuming that the ratio of positive decisions to negative decisions for these four units is also valid for the fifth unit, the total number of negative decisions comes down to 52 , which brings the total number of criminal investigations in which an undercover unit was consulted to $(37+52=) 89$ (see chapter 1 ). 
For infiltration, which is (even) less often used than systematic information gathering and undercover buys, we gathered information with regard to all 23 criminal cases during the 2000-2005 period in which a proposal for an infiltration operation was submitted to the CTC (chapter 3). ${ }^{148}$ Taken together, we used the following data sources: files of the Central Assessment Committee (in Dutch: Centrale Toetsingscommissie (CTC)), police files, information of the specialized police undercover units, interviews, and case law.

The research design, however, also has its limitations. For one thing, we did not interview undercover agents. Undercover agents were excluded mainly for security reasons. Undercover agents' security is a top priority when undercover operations are deployed. The circle of people familiar with their identity or appearance is kept as small as possible. We did, however, interview the agents' immediate supervisors, the heads of the special police undercover units. ${ }^{149}$

Another limitation relates to the fact that the cases we studied concern either 2004 or the 2000-2005 period. Has the investigative practice changed since then and, perhaps more importantly, are these changes of such a nature that they affect the validity of the results of our study? Institutional changes did take place. Whether these institutional developments actually changed the investigative practice cannot be determined, simply because there is no recent study with which to compare our results. We will discuss these as well as other possible changes below.

In 2005, there were five active, specialized undercover units within the Dutch police - one national and four regional teams. As the result of a reorganization that took place in 2008, the various undercover teams have been joined into one centrally controlled unit: the Unit Werken Onder Dekmantel (WOD), which translates as the Working Undercover Unit. This 'new' unit aimed, among other things, at the diversification of undercover agents, in terms of expertise and background, as well as the type of cases in which undercover operations are deployed. The undercover unit WOD consists of highly specialized police officers. In 2009, internal police guidelines ${ }^{150}$ were created for the deployment of regular police officers (i.e. not working in the WOD unit) for small, 'simple' undercover buys, such as the purchase of stolen property being on offer on the Internet. These police officers still have to be trained, but their training is far less intensive than the training required for members of the WOD unit. Whether and which effect the creation of the WOD unit and the accompanying changes have had on the investigative practice is not clear at this point. It is possible, however, that it has led to an increase of the use of undercover operations. In the

148 In fact, during the 2000-2005 period, authorization for an infiltration operation was requested in 24 investigations. However, one case was not included because the infiltration operation was still ongoing at the time the rearch was conducted.

149 There are studies focusing on the (psychological) effects of working undercover on police officers, e.g. Girodo, 1991; Girodo et al., 2002; Macleod, 1995; Miller, 2006. 
very month this last chapter of this thesis was finished, May 2016, a newspaper published information indicating that the use of undercover operations has indeed increased. In 2011, 2012 and 2013, according to the published information, the specialized undercover police unit (WOD) deployed operations in 55, 82 and 68 cases, respectively (Voskuil, 2016). The newspaper acquired this information as a result of a successful appeal to the Wet openbaarheid van bestuur (WOB), which translates as the Freedom of Information Act. Other factors might also have contributed to an increase in the use of this policing method. The possible reluctance among police officers and public prosecutors to use undercover operations may have decreased compared to fifteen years ago, for example, because the chronological and mental distance to the IRT affair has increased. ${ }^{151}$ Furthermore, the use of the Internet has probably become more important during the past decade, for offenders as well as for the police. Online undercover operations may be less laborious than offline operations are, possibly resulting in a rise of the total number of undercover operations.

A final remark, with regard to the scope of this study, concerns the interpretation of our research findings. Our research explored the results the police obtained by deploying undercover operations. We described the contributions these operations made to investigations and trials. One might wonder how the results of undercover policing should be judged: how good or bad are these results? Such a question cannot be answered (at this moment). First of all, since research on methods of criminal investigations is scarce, we cannot compare these results with results produced by other methods. Second, comparing results of methods of investigation is hard because, in general, the investigative practice differs greatly from a (classic) experimental setting in which the influence of a specific factor can be isolated from the influence of other factors. This applies in particular to investigations into organized crime. Methods such as undercover policing, the use of informers, wiretapping and/or bugging, are often used in combination with other methods. Information generated by one method is often used on behalf of (a more effective) deployment of another method. Furthermore, the circumstances under which methods are deployed differ and are not easy to control, e.g. regulation and its interpretation, and the reasons and goals guiding the choice of specific methods.

\section{Investments of organized crime offenders in the legal economy}

Empirical research on investments of organized crime offenders in the legal economy is scarce, too. Our study, discussed in chapter 4, gives insight into assets of offenders found in 150 cases from the Dutch Organized Crime Monitor. We argued that 'proximity' seems to be a better label for the investment choices offenders make than 'profitability' or 'power'

151 The change in regulation with regard to the use of criminal civilian infiltrators (see chapter 1) might be seen as an illustration of a decreasing reluctance towards the special methods of investigation that were highly criticized during the IRT affair and its aftermath. 
are. Above all, our results point to the importance of social embeddedness if we want to understand investment patterns, as opposed to, for example, economistic approaches (see also section 6.3.2). We do not pretend, however, that our results should be seen as a completely unequivocal or 'final' answer to questions concerning investments of organized crime offenders. Our study has its limitations.

Our research is mainly based on police files. As a consequence, our study only involves cases that were prioritized by the police and in which offenders were caught, just as it only includes assets about which the cases could produce some information. Using police files poses the risk that certain results remain undisclosed, not because the facts are not there, but simply because the police could not find them. ${ }^{152}$ A possible consequence may be that the importance of some types of assets or certain methods of money laundering are underestimated, such as investments in foreign countries. Furthermore, we focused on de facto ownership (control) instead of formal ownership, and we did not include cash money and deposits in our analyses. If formal ownership and cash money and deposits were included, the results might be different. Finally, our study involved organized crime in the Netherlands, which in large part boils down to transit crime (international illegal trade). Research on offenders who participate in other kinds of organized crime, such as racketeering, might produce (partially) different results, as is indicated by research on Mafia investments (e.g. Riccardi, 2014). ${ }^{153}$

\section{Investigating and confiscating the profits of organized crime}

In chapter 5, we empirically examined financial investigations and confiscation. By combining three data sources, i.e. case reports of the Dutch Organized Crime Monitor, data from the Central Fine Collection Agency (CJIB) and court files, the study contributes to the knowledge of the practice and results of 'following the money'. For a sample of 102 cases, we analysed data on the confiscation order court procedures as well as the collection of those confiscation orders. For those 102 cases, we presented a complete picture: from public prosecutors' claims and rulings of the initial court, the appeal court and the Supreme Court, to what offenders actually pay. Because by studying the court files, we also gathered information about the grounds on which a court decided whether or not to diverge from the prosecutor's claim (and/or from the decision of lower courts), we were also able to give a

152 One may argue that police files by definition do not cover assets, obtained with crime money, that were successfully laundered. However, this limitation is somewhat mitigated by the fact that, when checking the police files for available information on offenders' assets, every source of information was used, i.e. not only confiscated assets were taken into account but also, among other sources, intelligence from informers and monitored telephone conversations (see chapter 1).

153 Riccardi analysed companies confiscated in Italy. He argued that the investment portfolios of Mafia participants are determined by, among other factors, the possibilities to maximize territorial control and expand political and social support (Riccardi, 2014; Savona, 2015; see also Kleemans, 2015). 
qualitative interpretation of the numbers we delivered. Most of the relatively small number of other empirical studies do not provide a complete picture for the cases studied and/or lack qualitative insight into the different phases of confiscation.

We do not know whether or not our sample of 102 cases is representative of all cases of organized crime in which confiscation orders were used. However, the main results we found in our sample do correspond with what is known from other sources: a skewed distribution of confiscation orders (many 'small' and few 'large' confiscation orders) (Van Duyne et al., 2014); high levels of attrition during the court procedures (Openbaar Ministerie and Politie, 2015: 13-14); and high levels of attrition during the collection of confiscation orders (Minister van Veiligheid en Justitie, 2015: 3; requested data of CJIB, unpublished; Van Duyne et al., 2014; for England and Wales, see Bullock et al., 2009).

Our results only pertain to confiscation orders. The confiscation order, as an instrument to recover crime-related money, has received the most attention in the Dutch public debate on asset recovery. There are, however, other instruments, such as seizures and forfeitures and settlements out of court. In recent years, the total amount of recovered money has grown considerably, which is to a large extent due to settlements out of court. In section 6.3.3, we will elaborate on this.

Finally, the legislation with regard to confiscation has been changed several times (see chapter 5). In addition, the budget available for taking away criminals' money increased in 2011 as well as in 2013. Whether and, if so, what kind of effect these changes will have on the confiscation results (in the longer term), is unknown.

\subsubsection{Value of this study}

\section{Grasping the complexity of criminal investigations}

This study aimed, among other things, at producing a broad as well as deep insight into the use of undercover operations in criminal investigations. We studied actual cases, used an open, qualitative approach, and combined different data sources: police files (as well as CTC files), administrative information of police undercover units, interviews, and case law. This enabled us, not only to present information on the nature and number of undercover police operations in the Netherlands, but also to give insight into how this method contributes to investigations and trials, how the unpredictable interaction between undercover agents and their targets determines the course of undercover operations, and how regulation works out in the investigative practice.

Criminal investigation is a relatively neglected field of research for criminologists, especially when organized crime cases are concerned (e.g. De Poot, 2010: 102; Grabosky, 2010: 364). This does not mean that research on policing is entirely lacking. There is a growing number of evaluations of police activity, in the United States and the United Kingdom, for example. These studies fuel evidence-based policing as a method for 
making decisions about 'what works' in policing: which practices and strategies accomplish policing objectives most cost-effectively. Evidence-based policing studies centre on the quantitative measurement of processes and effects of policing, ideally by means of randomized controlled trials. Effects of policing are measured, using indicators such as victimization, recorded offences, recidivism, number of arrests and number of convictions. The evidence-based policing movement has generated an impressive number of evaluative studies on a broad range of topics, such as police approaches to domestic violence, the effects of the prosecution of juvenile offenders on repeat offending, and neighbourhood watch programmes (Sherman, 2013). Furthermore, it has contributed to the acknowledgement that research is important and that effort should be put into providing an empirical knowledge base for the use of police strategies.

However, not all relevant aspects of criminal investigations, nor all 'results' of specific methods of investigation, can be grasped by using a completely prestructured research design. Some topics of interest are too complex or under-researched to allow for such an approach. To gain insight into the investigative practice and results of undercover policing, for example, it was necessary to engage in in-depth analyses of actual cases in order to take into account the context in which this method is deployed, in terms of type of offenders and criminal activity, the offender-agent interaction, other methods deployed, choices made with regard to the undercover operation, and the outcome of the case. Because of our design, we were able to interpret the results of an undercover operation in relation to the specific characteristics of the criminal investigation in which it was used (De Poot, 2010: 102-104). In the existing literature on undercover policing, the 'results' of undercover operations are generally discussed in terms of arrests, seizures and convictions. However, as we illustrated in chapters 2 and 3, the reality of criminal investigation is less linear, and less simple, than seems to be assumed. Undercover operations may also contribute to criminal investigations in other ways. They can yield the insight that a suspicion is probably untrue and lead to the exclusion of a person from further investigation. Besides convictions (inclusion) and exclusion, an undercover operation may also generate steering information. Such information may be used, for instance, to deploy another method (more effectively), such as when information is gathered about the means of communication or the smuggling methods used by suspects.

Furthermore, the value of research into the deployment of methods of criminal investigation is much broader than exploring the results that these methods may produce. Methods of investigation, and counterstrategies to organized crime in general, are likely to involve a breach of fundamental human rights and are often the subject of legal and academic debate. To prevent these debates from being mainly based on untested assumptions, insight is needed into the way in which these methods are used and into how regulation works out in the investigative practice. Such an insight, at least when previous empirical 
research is scarce, requires an open, more qualitative approach and the use of various data sources, such as police files, interviews and case law. ${ }^{154}$

\section{Discussion: using police files in research}

Police files were an important data source for the empirical studies that are the basis of this thesis. Using police files for scientific purposes has certain limitations. The most fundamental limitation concerns the fact that the researcher depends on police processes for the selection of both persons (suspects) and topics. A police file is the result of many choices and factors that are beyond the researcher's influence: the choice of which offender or criminal group is to be targeted; the choice of which methods of criminal investigation are to be deployed; the choice of the topics information gathering should focus on; whether or not the police are successful in collecting that information; and the choice of how the results should be written down by the responsible police officer. Ultimately, police files only include persons who have come to the attention of the police and about whom the police were able and willing to collect information, and the same applies to activities these persons participate in. This could lead to biased research results. Activities of organized crime offenders that stay beyond the scope of the police remain hidden for the researcher as well. Furthermore, police reports of investigative activities are by definition written from a 'biased', i.e. criminal justice, perspective (see also Hobbs, 2013: 5-7).

However, from a researcher's point of view, police files also have important strengths. Everyone who wants to look into criminal phenomena, be it a journalist, a researcher or a police officer, is confronted with the 'walls of secrecy and silence' surrounding criminal activities, especially where organized crime is concerned (Van de Bunt, 2007, 2010). But only the police have exclusive powers to use far-reaching investigative methods to break through these 'walls'. A researcher who has access to police files benefits from these exclusive powers and may gain equally exclusive insights into the activities offenders participate in, or into the way they relate to each other and their environment.

A researcher may, of course, engage in interviews with offenders to talk about the same or other topics. Interviews with offenders can produce valuable insights (e.g. Van Koppen, 2013; for an overview, see e.g., Bernasco, 2010), may prove to be worthwhile and are necessary in relation to certain research aims. Yet, this means of data collection comes with its own fundamental problems, such as how to select respondents and get them to participate, how to create a natural environment for respondents and how to stimulate them to speak freely and truthfully. A researcher using transcripts of a bugged conversation between two drug traffickers in a 'safe' house, for example, does not have to

154 Quantitative approaches have very strong advantages of their own, just as studies at the other end of the spectrum, i.e. ethnographic $\mathrm{N}=1$ studies. Other aspects of organized crime policies are in fact suited for the application of quantitative methods (see section 6.4). 
deal with such problems. ${ }^{155}$ Policing methods are forced upon suspects; they are deployed without offenders' permission and sometimes, as is the case with bugging, wiretapping and undercover policing, even without them knowing. This 'unobtrusive' way of collecting data is very valuable for empirical research into topics that are hard to address through other empirical methods.

The value of police files for research purposes not only depends on whether or not a researcher has access to them, but also on the type of methods the police use and the amount of information the police write down in reports. In the Netherlands, the police are relatively open to researchers. In addition, Dutch police have to mention every method they have used in an investigation and write down the results (as far as relevant) in a report, whether it concerns undercover policing, bugging, wiretapping, the use of informers or any other method.

\subsection{Implications}

Given the empirical results, what lessons can be learned with regard to counterstrategies to organized crime? We will elaborate on this in three separate sections. In section 6.3.1, we will focus on the control and transparency of methods of criminal investigation. Section 6.3.2 will centre on the investments of organized crime offenders in the legal economy. In the last section, 6.3.3, we will discuss implications with regard to the investigation and confiscation of illegal profits.

\subsubsection{Controlling the use of special methods of criminal investigation}

The current Dutch legislation with regard to special methods of investigation was developed in the aftermath of the IRT affair. This affair, which took place roughly twenty years ago, centred on special investigation squads that used 'experimental' investigative methods to target organized crime groups. These special operations were deployed without (adequate) supervision and, since there were no specific sections in the Dutch code of criminal procedure that covered these methods, in a legal vacuum. The Parliamentary Inquiry Committee (PEO) that looked into the IRT affair concluded that, overall, criminal investigation in the Netherlands suffered from fundamental flaws (PEO, 1996, Eindrapport; see chapter 1).

The committee's report provided the foundation for the Act on Special Investigative Police Powers (in Dutch: Wet bijzondere opsporingsbevoegdheden (BOB Act)), which came into force in 2000. The BOB Act is built on three basic principles. First, special methods of criminal investigation should have a statutory basis, i.e. they should be covered by specific sections in the code of criminal procedure. With regard to undercover operations,

\footnotetext{
155 Although this example shows that drug traffickers might have very sound reasons to refrain from speaking their mind even in their own homes.
} 
the act distinguishes between three undercover powers. Second, the public prosecutor has the authority over a criminal investigation. The BOB Act enhances the role of the public prosecutor in the criminal investigation process. The public prosecutor formally decides on the use of investigative powers. Third, the use of methods of criminal investigation should be verifiable and, therefore, transparent; reports have to be made of the methods of investigation used and, in principle, these methods have to be accounted for at trial (Beijer et al, 2004: 277-278; Bokhorst et al., 2002: 185-186; Kleemans, 2007: 164-165).

The introduction of the $\mathrm{BOB}$ Act fits within a broader, international trend. Internationally, the past decades have shown a growth in instruments and measures strengthening the control of police activities (Cockcroft and Beatty, 2009; Hale et al., 2004; Newburn et al., 2007: 547-548; Neyroud and Disley, 2007: 552; Terpstra, 2011). Policing is increasingly subjected to formal, statutory regulation. This has occurred in continental law jurisdictions such as Belgium and the Netherlands, but also in common law jurisdictions such as England and Wales (Conway and Walsh, 2011: 241-242; De Roy and Van Dromme, 2004; Kruisbergen, Kleemans et al., 2012; Roberts, 2007: 97-102; Traest and Meese, 2000). Legislation has transformed a method such as undercover policing from an 'arcane and unregulated' means of investigation into a 'highly regulated process' (Neyroud and Disley, 2007: 553). Besides regulation with regard to specific methods of investigation, other, more general developments contributed to a strengthening of the control of police activities as well. ${ }^{156}$ One such development concerns a centralization (and standardization) process. Both the Dutch police and the Public Prosecution Service have been centralized (to a certain extent) and there is a body of (national) guidelines and standards regarding the conduct of criminal investigations (see also Hale et al., 2004; Terpstra, 2011: 101; Terpstra and Van der Vijver, 2005; Van de Bunt and Kleemans, 2007: 163-166, 182; Van de Bunt, 2004: 711-712). Performance management can be seen as another instrument to control police activities (Neyroud and Disley, 2007: 558-561). Due to the rise of performance management, policing as well as other public services are regarded as businesslike production processes; they are expected to be efficient and accountable (Manning, 2008: 284). In order to assess and manage performance, policing is centrally monitored on the basis of quantitative results. ${ }^{157}$

156 Neyroud and Disley commented on the growing supervision of criminal investigations in the United Kingdom. They stated that, today, 'every role is defined, every action logged and every decision externally accountable' (Neyroud and Disley, 2007: 568).

157 In 2003, the Dutch government introduced performance contracts, including measurable results that regional police forces had to achieve. In 2007, the system was altered: less emphasis was placed on quantitative performance indicators. However, according to Terpstra, police forces internally often retained fixed production targets (Terpstra, 2011: 91-96). Furthermore, quantitative performance indicators, e.g. with regard to the number of criminal collaborations targeted and the amount of crime money recovered, are central in recent policy documents on the fight against organized crime (e.g. Openbaar Ministerie and Politie, 2015). 
Regulation, performance management, and centralization and standardization all seek 'to rationalize what is, in reality, a highly complex, "messy" task (...)' (Neyroud and Disley, 2007: 553). The potential invasiveness of police activities justifies the attempts to rationalize and control criminal investigations. The 'need to have control' is especially strong where a controversial method such as undercover policing is concerned. ${ }^{158}$ Thanks to the BOB Act, methods of investigation such as undercover policing are subjected to specific rules in the code of criminal procedure; the legal vacuum within which the police operated before the introduction of this act no longer exists. Furthermore, the act has improved the transparency of the use of special methods of investigation and it has strengthened the public prosecutor's authority (Beijer et al., 2004; Bokhorst et al., 2002). However, not every aspect of legislation and other control-strengthening instruments is perfectly attuned to the investigative practice. First, detailed regulation and judicial distinctions may not always fit the investigative practice. The execution of the type of undercover operation for which the legislator has stipulated the lightest conditions (systematic intelligence gathering), may in practice be more invasive than the execution of the legally most serious undercover operation (infiltration) (chapter 2). Second, centralized authorization procedures with regard to infiltration may lead to 'interference aversion' (chapter 3). Third, testing proposed infiltration operations prospectively for subsidiarity, clashes to a certain extent with the fundamental unpredictability that characterizes investigations into organized crime (chapter 3). Fourth, it can be argued that the complex and unpredictable nature of criminal investigations into organized crime also relates badly to the increased need for controllability that goes with a focus on performance management. ${ }^{159}$

The need to regulate and control police operations has been soundly justified, as we just explained. Furthermore, the fact that regulation and authorization procedures, for example, can in some cases produce unwanted outcomes, does not imply that the BOB Act or authorization procedures as such are inadequate. Our results do indicate, however, that the investigative practice is unpredictable and complex and less malleable than regulation, authorization procedures, performance management and other control-strengthening instruments would suggest. Policing in general and investigations into organized crime in particular will probably continue to be the subject of debate. These debates should not focus on further strengthening the (illusion of) direct control of the process of criminal investigation. Rather, effort should be put into enhancing the transparency of the investigative practice, the most essential principle of the BOB Act. Criminal investigations are 'controllable' (steerable) only to a limited extent, yet they can and should be made 'verifiable' and 'evaluable'.

\footnotetext{
158 According to Walsh and Conway (2011: 61), the rise of proactive policing strategies is one of the reasons for the growing attention for questions regarding police governance and accountability.

159 Our own empirical research did not centre on the application of performance management with regard to criminal investigations. For a review of the side effects of management guided by output, see, for example, Van Thiel and Leeuw, 2002 (see also Cockcroft and Beattie, 2009; Garland, 2002: 119-120; Pollitt, 1993; Ross, 2007: 520-521).
} 


\section{Transparency}

Obviously, the investigative process, let alone undercover policing, can never be fully transparent. Transparency, however, can and should be enlarged (Walsh and Conway, 2011: 71; Kruisbergen, Kleemans et al., 2012). The BOB Act certainly has improved the transparency of the use of methods of investigation. The act requires that a report is made of the methods of investigation used and that the deployment of special police powers will, in principle, be accounted for at trial (Beijer et al, 2004: 277-278). Before the introduction of the BOB Act, judges were often not even informed about the fact that an undercover operation had been used (Van Traa, 1997: 16). An evaluation of the BOB Act showed that Dutch judges seem satisfied with the reporting of and insight given into the use of investigative methods (Beijer et al., 2004: 282). This also shows when court decisions regarding undercover operations are examined (chapter 2). However, there is more to transparency than accountability in court. Methods of criminal investigation should also be subjected to other types of critical evaluation, other than from a purely judicial perspective that focuses mainly on singular cases, as takes place in court.

Methods of criminal investigation, and organized crime policies in general, should be the subject of debate, and they are. Unfortunately, both the academic and the legislative debate are for an important part based on normative grounds and untested assumptions, simply because sufficient empirical information is lacking. In the current situation, in the Netherlands, there is almost no publicly available information that provides basic insight into the investigative practice of undercover policing. Recently, in May 2016, a newspaper published information on the number of undercover operations in three consecutive years. The newspaper received the information as a result of a successful appeal to the Freedom of Information Act (see section 6.2.1). Yet, in general, information on matters such as the number and the form of undercover operations deployed each year, the crimes these operations target, and the results they generate, is not available. The same is true for many other methods of investigation. Furthermore, research on how and when certain methods are used and how regulation is actually implemented, is scarce.

A larger knowledge base would provide a stronger foundation for academic and legislative debate. A stronger empirical foundation would also improve the possibilities of regulatory bodies to monitor the use of investigative methods and to make well-informed decisions regarding these methods. As a result, regulatory quality may benefit. To realize this foundation, information on the topics as mentioned should be generated, and made available, on a regular basis. Furthermore, criminologists and other researchers should choose, and be allowed, more often to study the investigative practice.

The affair that resulted in the appointment of a Parliamentary Inquiry Committee on Criminal Investigation Methods (PEO) (and ultimately led to the BOB Act), took place roughly twenty years ago. Due to its thorough fact-finding work, the committee could feed the legislative debate with information. The transparency that was realized by the 
committee's work, should, to a certain extent, be continued and should not be dependent on an 'affair' or specific request to initiate such openness.

\subsubsection{Crime money and the legal economy}

In chapter 4 , we concluded that, as a theoretical approach to organized crime, a social opportunity approach is useful to understand offenders' investments in the legal economy. An offender's options for investment are defined and limited by the opportunities he finds in his direct social environment. A social opportunity approach (proximity) turned out to be better suited to describe these investments than a standard economic approach (profitability) or an infiltration approach (power) would be. Our 'rejection' of the standard economic approach, or perhaps we should say an economistic approach, does not imply, of course, that we believe that offenders object to making a profit when they invest their money in the legal economy. Nor does our rejection of the infiltration approach mean that influence and power in regular society are completely irrelevant where offenders' investments in the legal economy are concerned. Although power might not be the main driving force when an offender invests his money, these investments could ultimately lead to such influence, especially when an offender or criminal group remains beyond the scope of the police for a long time. The prevention of criminal infiltration in legal society is, therefore, one of several reasons why the investigation and confiscation of criminal earnings is so important.

Results of the analysis of the investments of organized crime offenders, as well as other studies, showed that real estate is a popular investment category (Webb and Burrows, 2009: 27; Matrix Knowledge Group, 2007: 39; Malm and Bichler, 2013). For an offender, investing in real estate has several benefits. First, real estate is often seen as a safe and profitable investment. Second, real estate can absorb a lot of money. Third, real estate markets lack price transparency. A fourth advantage lies in the fact that the ownership of property can be concealed. In the fifth place, criminals need a place to live, just like everyone else (Soudijn and Akse, 2012; WEF, 2011: 9-11; Van Gestel, 2010; KLPD, 2008: 141; Kruisbergen, Van de Bunt et al., 2012: 214). ${ }^{160}$ The real estate market is of great importance for the legal economy as well. This implies that it may be difficult to take effective measures against the influx of crime money in the real estate market, that will not have any effect on legal actors at the same time. It may be worthwhile, however, to invest in such measures and to (further) intensify the focus of law enforcement agencies on real estate. ${ }^{161}$

160 The drawback of investing money in real estate (at least when you actually buy a house, for example, instead of investing your money in real estate-related financial products), is that it may be hard to transfer your investment into cash, especially during a period when the volume of transactions is low (Soudijn, 2011: 44-45).

161 Recently, various measures have been (are being) developed to limit the vulnerability of the property market to money laundering. At the moment when this thesis was finalized (summer 2016), it was not yet clear how these measures, such as the implementation of the fourth EU anti-money laundering directive (Directive (EU) 2015/849), will work out (see also Minister van Veiligheid en Justitie, 2016). 


\subsubsection{Investigating and confiscating the proceeds of organized crime}

Since the confiscation legislation came into force, there have been several initiatives to enhance the legal possibilities for asset recovery. These initiatives are often born out of the desire to solve perceived problems in the existing legislation or in its implementation. However, some of these initiatives seem to be more inspired by indignation over disappointing results, than by adequate insight into the practice of confiscation (see also Borgers and Simmelink, 2005b; Borgers et al., 2007). Looking at the parliamentary debate, some initiatives suggest that attrition is mainly caused by legislation or its implementation that is too lax.

An example is the legislation that came into force January $2015 .{ }^{162}$ The amendment is intended to limit the actual deduction of costs when the amount is determined of the criminal profit that has to be confiscated. The parliamentary debate on this topic showed that there was discontent about the fact that, in some cases, judges deduct criminal business costs when they determine the criminal profit an offender has made. Although the explanatory memorandum to the confiscation law, as it was introduced in 1993, explicitly mentions the possibility of deducting costs (Tweede Kamer, 1989-1990, 21 504, no. 3: 16), which has been explained further in case law that came into being since then, the deduction of costs appears to be interpreted as an unjustified favour done to offenders. The amendment that became effective in January 2015 is meant to undo the perceived imbalance in the implementation of the confiscation law (Tweede Kamer, 2011-2012, 29 911, no. 56, 57; Tweede Kamer, 2012-2013, 33 685, no. 3; Kooijmans and Borgers, 2012).

The question is, however, whether this initiative is based on a sound problem analysis. The amendment itself is in line with the legal practice before it came into force; costs can only be deducted under certain conditions. This would render the amendment somewhat redundant, although the explanatory memorandum makes clear that the amendment is intended to limit the actual deduction of costs (Kooijmans and Borgers, 2012; Borgers and Simmelink, 2005b). Furthermore, it seems that the interpretation of this legal practice as being too lax, is more an expression of the opinion that deduction of costs is wrong in itself, than it is the result of a thorough analysis of case law. More importantly, the assumptions underlying initiatives such as this - 'offenders are getting away too easily' - are preventing a clear picture of the real problems.

The results presented in chapter 5 indicate that an important factor causing attrition is how 'criminal profit' is defined (determined) in law and practice. With regard to attrition during the court procedures, this concerns the fundamental difficulty of unambiguously determining the amount of 'criminal profit'. The definition of 'criminal profit' in law and

162 Complete reference in Dutch: Wet van 19 november 2014 tot wijziging van het Wetboek van Strafrecht, het Wetboek van Strafvordering en de Wet op de economische delicten met het oog op het vergroten van de mogelijkheden tot opsporing, vervolging, alsmede het voorkomen van financieel-economische criminaliteit (verruiming mogelijkheden bestrijding financieel-economische criminaliteit), Stb. 2014, no. 445. 
judicial practice probably also plays an important role in the attrition taking place during the collection of confiscation orders. Precisely because spending behaviour and losses during criminal transactions are in part not taken into account when estimating the amount of money an offender should pay, a part of the confiscation orders is likely to remain not fully paid. ${ }^{163}$

The policy and debate with regard to 'follow the money' should be fuelled more by pragmatism, facts and analysis. Members of Parliament and members of government are very productive where new policy initiatives are concerned. Debate and legislative initiatives may be improved by increased insight into the practice of financial investigation and confiscation, as well as a sound analysis of the goals to be achieved, instruments to be used, and problems to be solved. Further debate on 'follow the money' should include the following points of departure.

First, a financial investigation is much more than a necessary condition for the confiscation of assets. The debate seems to be focused on taking away criminals' money, but financial investigation has a much broader function for fighting crime. The non-financial value of financial investigations is perhaps underestimated. Financial investigation may help identify new suspects, provide information on suspects' movements, and give new insights into the role of different suspects (Brown et al., 2012: 5-9; Levi, 2013; see also Slot et al., 2015). When financial investigation succeeds in discovering money flows, it may also help to prove an offender's involvement in the crime that generated the money. This is the case, for example, in cases of human trafficking and extortion, where the transfer of money from a victim to an offender can be used to sustain a suspicion against the latter (Nationaal Rapporteur Mensenhandel en Seksueel Geweld tegen Kinderen, 2014: $145-146){ }^{164}$

163 Attrition is also caused by the fact that offenders successfully hide their assets. Tracing and seizing assets, for example, is complicated by the fact that a part of offenders' assets is located abroad (chapter 4). A more adequate international cooperation may facilitate a more effective financial investigation and confiscation of assets abroad, which in turn would reduce attrition during the collection phase and contribute to counter international organized crime.

164 An aspect of financial investigation that is certainly not underestimated, perhaps the opposite, is its financial value. Investments in financial investigation are expected to result in significant increases in the amount of recovered money. Financial investigations are assumed to 'pay for themselves ', and (much) more. Whether the financial benefits generated by 'follow the money' indeed exceed the costs, is questionable, as research in the United Kingdom indicates (Levi, 2013: 10; Sproat, 2009; Collins and King, 2013; Bullock, 2014: 63) (furthermore, the cost-benefit ratio probably differs greatly among the different instruments used to take away criminals' money, as is explained in this section). Financial profitability is not - or should not be - the main issue involved in the confiscation of crime money. In addition to reinforcing the ideological standpoint that 'crime should not pay', it may serve to prevent future criminal activities. The fact that confiscation orders are not paid in full, does not mean that they - let alone other measures - are completely ineffective in producing the intended effects. It is due to confiscation orders and other measures that money is indeed taken away from offenders. That should at least have some impact on them. 
Second, those involved in the debate on 'follow the money' should recognize the distinction between different instruments used to take away criminals' money. Taking away criminals' money is often discussed as if it is a homogeneous activity. Yet, the possible costs and benefits as well as the applicability of instruments such as confiscation orders, settlements out of court, and cash seizures, differ greatly.

In recent years, the value of recovered money has grown considerably. Taking together confiscation orders, settlements out of court, and cash and other seizures and forfeitures, the total value of assets taken away from offenders has risen each year during the 2012-2015 period: $€ 50$ million in 2012, €90 million in 2013, €136 million in 2014 and $€ 144$ million in 2015. In 2012, the collection of confiscation orders generated $€ 19.6$ million, almost $40 \%$ of the total value of recovered assets, whereas in 2015 , the collection of confiscation orders generated $€ 22.8$ million, a near $16 \%$ of the total amount (rounded numbers). The impressive rise of the total value of recovered assets is caused for a significant part by a few 'white-collar' crime cases that have been settled out of court. In 2013, the First Curacao International Bank N.V. (FCIB), which was convicted for acting in contravention with financial regulation, paid a settlement of $€ 35$ million. In 2015, SBM offshore paid $€ 61$ million as part of a settlement for involvement in bribery (Minister van Veiligheid en Justitie, 2013, 2015; Openbaar Ministerie, 2014, 2015, 2016; requested data of CJIB, unpublished). Another relevant factor concerns the focus of the police in recent years on underground banking and money couriers, which results in the seizure of considerable amounts of cash money (Openbaar Ministerie and Politie, 2015). Instead of bringing all the arrested money couriers (and bankers) to court, the Public Prosecution Service chooses to settle some cases out of court, especially where first offenders are involved. In those cases, the couriers lose the money they carried and have to pay an additional sum.

In the white-collar crime cases just mentioned and the cases against (the first offenders among the) money couriers, the cases were settled out of court. In this way, although large sums of money are recovered, long-lasting court procedures, which confiscation procedures can turn into, are avoided. Furthermore, the collection of the money is realized with relative ease: the parties involved in settlements agreed to pay (and they really do (Minister van Veiligheid en Justitie, 2015)). As far as the couriers are concerned, their money is seized the moment they are arrested. ${ }^{165}$ With regard to the cost-benefit ratio of asset recovery, settlements and seizures and forfeitures are probably more efficient than confiscation orders are. However, efficiency is not the only criterion, nor is it perhaps the most important one.

The instruments also differ significantly from one another in their applicability. Settlement out of court, for example, is only feasible in cases in which both the Public Prosecution Service and the suspect are willing (and able) to settle (pay). Seizing cash,

165 Except, of course, for the additional sum they have to pay. 
obviously, is only possible in cases in which there is cash to be found. The distinction between these different instruments, in terms of their applicability and possible costs and benefits, should play an important role in debates on asset recovery. ${ }^{166}$

Third, and most fundamentally, thoughts have to be spent on what we hope to achieve with financial investigation and confiscation. There are significant functional and economic differences between the instruments to recover assets, as was just explained. If recovering a maximum amount of money for the lowest costs is a target, settlements out of court and cash seizures are perhaps more appropriate instruments than confiscation orders are. If, on the other hand, authorities uphold the general principle that they should at least try to recover every illegally obtained euro, then they should accept that the financial costs might very well be higher than the financial returns. And in so far as the main priority of followthe-money efforts is not asset recovery in itself but rather the disturbance and prevention of organized crime, this might again lead to different choices, choices that should be based on adequate analyses of financial aspects of different types of organized crime.

\subsection{Research on counterstrategies to organized crime}

In this final section, we will discuss some directions for further research on counterstrategies to organized crime.

\subsubsection{Why should we do research on organized crime policies?}

Why should we do research on organized crime policies? The scientific importance of a study is determined by the extent to which it produces empirical 'evidence' regarding research questions that have not yet been adequately addressed. It is also determined by the extent to which it contributes to the theoretical understanding of the topic of interest. In this respect, it is not hard to make a case for more research on organized crime policies and related phenomena, simply because empirical research in this area is relatively scarce. Many questions have still to be answered. These questions relate to issues such as the choices made, methods used and results produced during criminal investigations into organized crime; how offenders handle the financial aspects of their activities; and the interaction between organized crime policies and the way offenders operate.

Besides its scientific importance, research may also be judged in terms of societal relevance. Will research on organized crime policies lead to a greater number of arrested and convicted organized crime offenders, and will it produce an increase in the amount of money taken away from criminals? Such direct effects should neither be the aim nor the justification of research in this area. Practitioners such as police officers and public

166 In May, 2015, the Minister of Security and Justice complied with a request of Parliament for an overview of the amounts of money that were recovered as a result of the respective instruments (Minister van Veiligheid en Justitie, 2015). 
prosecutors know how to catch offenders (Kleemans, 2014a). The societal relevance of research on organized crime policies lies primarily in its ability to provide an empirical basis for debate, policymaking and democratic control. The results of this thesis indicate that some implicit assumptions underlying the legal and/or academic debate might be flawed and that some regulatory procedures might produce unwanted outcomes. This does not mean that certain policies are completely erroneous or that actors involved in the debate are incapable. Because of the scarcity of empirical information, it is simply inevitable that organized crime policies and debates are based on untested assumptions. That is exactly why empirical research is important (Kleemans, 2014a; see also Leeuw, 2003, 1991).

\subsubsection{Suggestions for further research}

As far as undercover policing is concerned, future research should focus on, among other topics, online undercover operations (as compared to undercover operations in the offline world). The Internet offers possibilities for criminals as well as for law enforcement agencies. The Internet offers offenders possibilities, for example, to reach customers, co-offenders or victims who might remain out of reach in the offline world. Likewise, police officers can exploit the possibilities to set up online cover identities and front stores. Online undercover operations relate to issues concerning transparency as well, since online interactions between an undercover agent and his target can, at least in principle, be logged with relative ease. How are these possibilities used in practice, does the dynamic of online interactions differ fundamentally from offline interactions between undercover agents and their targets, and are there any specific risks involved in online undercover operations?

Empirical research on the use of methods of criminal investigation is relatively scarce. So far, some studies have been done on, for example, the use of specific methods of investigation such as undercover operations (the present study; Kruissink et al., 1999) and wiretapping (Odinot et al., 2012; Reijne et al., 1996). Bugging of face-to-face conversations and the use of crown witnesses are two other methods that, because of their perceived invasiveness, the perceived risks attached to them, and/or because they are heavily debated, deserve to be the subject of in-depth study (see Beune and Giebels, 2013). However, there is more to criminal investigation than choosing which investigative method to use. Police officers and public prosecutors targeting organized crime have to make other choices as well: who are the main suspects; how many suspects should be targeted; should the focus be on leading figures, lower-level suspects and/or facilitators; and should investigative efforts focus on gathering as much evidence as possible regarding the most serious criminal activities, or should the aim be to intervene as soon as possible? Case studies might shed light on how these and other choices are made, enlarging our understanding of the investigative process (see also De Poot et al., 2004). Such studies should focus specifically on the extent to which the course of a criminal investigation is determined by strategic and tactical considerations of the investigation team or by 
factors beyond its control, such as incidents in the criminal environment. This last issue brings us to perhaps one of the most interesting questions in this area: how do offenders interact with the counterstrategies law enforcement agencies deploy against them (e.g. Spapens, 2006)? Studying interaction more or less implies that a researcher follows his research subjects for a longer period of time. That makes this question as interesting as it is methodologically hard to address. However, using data such as reports of wiretapping, bugging and observation operations, and transcripts of interrogations, might produce some answers to questions such as how offenders anticipate police activities, how they react to seizures and arrests of fellow offenders, and how adaptable their modus operandi is.

With regard to the financial approach to organized crime, there are also many topics of interest that are currently not sufficiently addressed. Empirical research on how offenders actually spend their money, for example, is still relatively scarce. Qualitative as well as quantitative methods can and should be used to reach a higher level of knowledge. Qualitative, in-depth research is necessary to gain insight into the mechanisms and considerations that shape the spending behaviour of organized crime offenders. To gain these insights, effort should be put, among other sources, into getting information from the ones who know best, the offenders themselves (e.g. Matrix Knowledge Group, 2007; Webb and Burrows, 2009). This might also partially compensate for the bias resulting from relying on police data, although we realize that interviewing offenders has its own difficulties. The insights generated by qualitative research can, in turn, give direction to quantitative analyses on casefiles and databases of seized assets. Those analyses may focus on the type, magnitude and place of investment as well as on possible differences on these issues between different types of offenders.

Another topic of interest concerns money laundering methods, digital methods specifically. The use of crypto currencies such as bitcoin for money laundering purposes, for example, raises some interesting questions. How do offenders handle their illegally obtained bitcoins; do they transfer most of it into traditional currencies or is part of it spent or stalled as bitcoin? Do bitcoin-related money laundering services mainly concern the transfer of bitcoins into traditional currencies or does it also work the other way around, i.e. offenders who exchange their illegally obtained euros or dollars for bitcoins? What are the main bottlenecks for offenders to use bitcoin for their operations? And does the illegal use of this 'new' payment method also bring with it a new type of facilitators?

Furthermore, researchers should focus on increasing insight into the practice and results of financial investigation and confiscation (see also chapter 5). The financial approach is based on the idea that taking away their money 'hits them where it hurts most'. Yet, little is known about the effects of this approach. To what extent and how are offenders and the criminal activities they engage in affected? Different methods should be explored to address these matters. Databases with criminal records can be used for a quantitative analysis of levels of recidivism of offenders who were 'hit' financially, compared to those 
who were not. Qualitative methods can contribute to understanding how financial sanctions may work out. Studying police sources such as recorded conversations between offenders, and interviewing offenders, can shed some light on how offenders anticipate and react to these sanctions (e.g. Vruggink, 2001).

\subsubsection{Concluding remarks}

In this chapter, we argued for more research and more transparency with regard to organized crime policies. More research and transparency will generate a more thorough insight into how organized crime policies work out in practice. This, in turn, allows for more rational discussions on this topic. This is not to be confused with a plea for the further rationalization of police activities in the sense of more regulation, more controllability, et cetera. A greater insight into how organized crime policies work out in practice might, in fact, for some be reason to plead for new or adjusted regulation. For others, however, such an insight will be a reason to adjust one's image of 'organized crime' or to make comments on existing policy theories. This is up to policymakers and others involved in the organized crime debate. Providing a foundation for debates on and democratic control of organized crime policies, is what researchers should aim for.

Recently, the call for societal relevance and the valorisation of research is intensifying. It is not so hard, compared to other fields of interest, to point to the potential societal value of research on crime-related issues. When discussing this societal value, one readily comes across the argument that more knowledge leads to more effective crime policies and hence to less crime. Working from this perspective on policy-relevant research, research often focuses on what works and best practices. The societal relevance of research that actually does generate answers to questions with regard to what type of instruments are most effective in reducing crime, is beyond dispute. A focus on what works, however, ignores a preceding question that, given the current level of empirical knowledge as well as the complexity of organized crime and its control, is perhaps more essential: How does it work? 


\section{References}

Akse, Th. (2003). En de kleur is vuil. Zoetermeer: KLPD.

Albanese, J.S. (2011). Transnational Crime and the 21st Century. New York: Oxford University Press.

Allen, R.J., Luttrell, M., and Kreeger, A. (1999). Clarifying entrapment. The Journal of criminal Law and Criminology, 89(2): 407-431.

Andreas, P. and Nadelmann, E. (2006). Policing the Globe: Criminalization and Crime Control in International Relations. Oxford: Oxford University Press.

Ashworth, A. (2002). Re-drawing the boundaries of entrapment. Criminal Law Review, 3, 161-179.

Ayling, J. (2013). Haste makes waste: Deliberative improvements for serious crime legislation. Australian and New Zealand Journal of Criminology, 46(1): 12-31.

Ayling, J. (2014). "Going Dutch"? Comparing Approaches to Preventing Organised Crime in Australia and the Netherlands. The European Review of Organised Crime, 1(1): 78-107.

Baicker, K. and Jacobson, M. (2007). Finders keepers: Forfeiture laws, policing incentives, and local budgets. Journal of Public Economics, 91(11/12): 2113-2136.

Barone, R., and Masciandaro, D. (2011). Organized crime, money laundering and legal economy: theory and simulations. European Journal of Law and Economics, 32: 115-142.

Bartels, L. (2010). A Review of Confiscation Schemes in Australia. Technical and Background Paper No. 36. Canberra: Australian Institute of Criminology.

Bean, P. (2001). Informers and witness protection schemes. In R. Billingsley, T. Nemitz and P. Bean (eds.), Informers: policing, policy and practice (153-163). Devon: Willan Publishing.

Beare, M. and Woodiwiss, M. (2014). U.S. organized crime control policies exported abroad. In L. Paoli (ed.), The Oxford Handbook of Organized Crime (545-571). Oxford: Oxford University Press.

Beckert, J. and Wehinger, F. (2013). In the shadow: illegal markets and economic sociology. SocioEconomic Review, 11(1): 5-30.

Beijer, A., Bokhorst, R.J., Boone, M., Brants, C.H. and Lindeman, J.M.W (2004). De Wet Bijzondere Opsporingsbevoegdheden: Eindevalvatie. Meppel: Boom Juridische Uitgevers.

Bernasco, W. (ed.) (2010). Offenders on offending: Learning about crime from criminals. Cullompton, Devon: Willan Publishing.

Beune, K. and Giebels, E. (2013). The management of protected witnesses: A behavioural perspective. Enschede: Universiteit Twente.

Billingsley, R. (2001). Informers' careers: motivations and change. In R. Billingsley, T. Nemitz and P. Bean (eds.), Informers: policing, policy and practice (pp. 81-97). Devon: Willan Publishing. Billingsley, R. (2008). Editor's Introduction. In R. Billingsley (ed.), Covert Human Intelligence Sources. The 'Unlovely' Face of Police Work (pp. xiii-xxv). Sherfield Gables: Waterside Press. Billingsley, R. Nemitz, T., and Bean, P. (2001a). Introduction. In R. Billingsley, T. Nemitz and P. Bean (eds.), Informers: policing, policy and practice (pp. 5-24). Devon: Willan Publishing. 
Billingsley, R. Nemitz, T. and Bean, P. (eds.) (2001b). Informers: policing, policy and practice. Devon: Willan Publishing.

Bokhorst, R.J., Kogel, C.H. de, and Van der Meij, C.F.M. (2002). Evaluatie van de Wet BOB - fase 1: De eerste praktijkervaringen met de Wet Bijzondere opsporingsbevoegdheden. Den Haag: Boom Juridische uitgevers.

Borgers, M.J. (2001). De ontnemingsmaatregel: Een onderzoek naar het karakter en de voorwaarden tot oplegging van de maatregel ter ontneming van wederrechtelijk verkregen voordeel (artikel $36^{\mathrm{e}}$ Wetboek van Strafrecht). Den Haag: Boom Juridische Uitgevers.

Borgers, M.J. and Simmelink, J.B.H.M. (2005a). Recente rechtspraak over de ontnemingsmaatregel: Het voordeelsbegrip en hoofdelijkheid. Delikt en Delinkwent, 3: 335-349.

Borgers, M.J. and Simmelink, J.B.H.M. (2005b). Oplossingen voor niet bestaande problemen met de ontneming van voordeel. Nederlands Juristenblad, 19: 992-993.

Borgers, M.J., Kooijmans, T. and Simmelink, J.B.H.M. (2007). Hoofdelijkheid bij ontneming van voordeel: Alweer een oplossing voor niet-bestaande problemen. Nederlands Juristenblad, 1, 17-20.

Bowers, R. and McCullough, J. (1982). Assessing the 'Sting': An Evaluation of the LEAA Property Crime Program. Washington, DC: University Science Center.

Brå (Brottsförebyggande rådet) [The Swedish National Council for Crime Prevention] (2008). Criminal Assets Recovery in Sweden, English summary of Brå report no. 2008:10. Stockholm: Brå.

Brodeur, J.P. (1992). Undercover Policing in Canada: Wanting What Is Wrong. Crime, Law and Social Change, 18: 105-136.

Brown, R. (2013). Reaching the parts other investigations cannot reach: Securing convictions for organised crime through financial investigation. Journal of Financial Crime, 20(3): 259-266.

Brown, R., Evans, E., Webb, S., Holdaway, S., Berry, G., Chenery, S., Gresty, B. and Jones, M. (2012). The Contribution of Financial Investigation to Tackling Organised Crime: A Qualitative Study. London: Home Office.

Brown, R. and Gillespie S (2015). Overseas financial investigation of organised crime: Examining the barriers to effective implementation. Journal of Money Laundering Control, 18(3): 371-381.

Bruinsma, G.J.N. (1996). Georganiseerde misdaad en legale economische sectoren. In F. Bovenkerk (ed.), De georganiseerde criminaliteit in Nederland (pp. 125-132). Gouda: Quint.

Bruinsma, G.J.N., and Bovenkerk, F. (1996). Inleiding. In G.J.N. Bruinsma and F. Bovenkerk (eds.), De georganiseerde criminaliteit in Nederland: branches (pp. 2-8). Den Haag: SDU.

Bullock, K. (2010). The confiscation investigation: Investigating the financial benefit made from crime. Policing: A Journal of Policy and Practice, 4(1): 7-14.

Bullock, K. (2014). Criminal benefit, the confiscation order and the post-conviction confiscation regime. Crime, Law and Social Change, 62(1): 45-64.

Bullock, K., Mann, D., Street, R. and Coxon, C. (2009). Examining Attrition in Confiscating the Proceeds of Crime. London: Home Office. 
Burt, R.S. (1992). Structural holes. Cambridge, MA: Harvard University Press.

Butterfield, R., Edwards, C. and Woodall, J. (2005). The New Public Management and Managerial Roles: The Case of the Police Sergeant. British Journal of Management, 16(4): 329-341.

Cabana, P.F. (2014). Improving the recovery of assets resulting from organised crime. European Journal of Crime, Criminal Law and Criminal Justice, 22(1): 13-32.

Choo, A.L.T. and Mellors, M. (1995). Undercover Police Operations and What the Suspect Said (or Didn't Say). Web Journal of Current Legal Issues, 2: 8-10.

Clarke, R.V. and Felson, M. (eds.) (1993). Routine activity and rational choice. Advances in criminological theory, Vol 5. New Brunswick: Transaction.

Cockcroft, T. and Beattie, I. (2009). Shifting Cultures: Managerialism and the Rise of "Performance". Policing: An International Journal of Police Strategies and Management, 32(3): 526-540.

Cohn, E.G. and Farrington, D.P. (2012). Scholarly Influence in Criminology and Criminal Justice Journals in 1990-2005. Criminal Justice Review, 37(3): 360-383.

Collins, M. and King, C. (2013). The disruption of crime in Scotland through non-conviction based asset forfeiture. Journal of Money Laundering Control, 16(4): 379-388.

Colquitt, J.A. (2004). Rethinking Entrapment. American Criminal Law Review, 41: 1389-1437.

Conway, V. and Walsh, D.P.J. (2011). Current Developments in Police Governance and Accountability in Ireland. Crime, Law and Social Change, 55(2-3): 241-257.

Court of Audit (2014). Combating Money Laundering: State in 2013. The Hague: Court of Audit.

Croes, M. (2005). Leren van het verleden? Centraal of lokaal aangestuurde politie in Nederland. Tijdschrift voor Criminologie, 47(4): 395-401.

CTC (Centrale Toetsingscommissie [Central Assessment Committee]) (2009). Jaarverslag 2008 [Annual Report 2008]. Rotterdam: CTC

D'Andria, D. (2011). Investment strategies of criminal organizations. Policy Studies, 32(1), 1-19.

De Poot, C.J., Bokhorst, R.J., Van Koppen, P.J. and Muller, E.R. (2004). Rechercheportret. Over dilemma's in de opsporing. Alphen aan den Rijn: Kluwer.

De Poot, C.J. (2010). Kennisgestuurd rechercheren: evidence based onderzoek voor de opsporingspraktijk. Cahier Politiestudies, 2010-4/17: 101-125.

De Roy, C. and Van Dromme, S. (2004). Bijzondere opsporingsmethoden en aanverwante onderzoeksmethoden. Antwerpen: Intersentia.

Den Boer, M. (1997). Undercover Policing and Accountability from an International Perspective. Maastricht: European Institute of Public Administration.

Den Breejen, M. (2011). Pseudokoop of simpel politieoptreden. Blauw, 21: 16-20.

Dillof, A.M. (2004). Unraveling unlawful entrapment. The Journal of Criminal Law and criminology, 94/4: 827-896.

Enhus, E. and Ponsaers, P. (2005). Onmacht tot cultuurverandering. Politiehervorming in België. Tijdschrift voor Criminologie, 47(4): 345-354. 
European Monitoring Centre for Drugs and Drug Addiction (2015). European Drug Report 2015. Trends and Developments. Luxembourg: Publications Office of the European Union.

Europol (2006). OCTA: EU organized crime threat assessment. The Netherlands: European Police Office.

Fernández Steinko, A. (2012). Financial channels of money laundering in Spain. British Journal of Criminology, 52(5): 908-931.

Fijnaut, C.J.C.F. (1983). De zaak-François: Beschouwingen naar aanleiding van het vonnis. Antwerpen: Kluwer.

Fijnaut, C.J.C.F. (2014). Criminologie en strafrechtsbedeling. Een historische en transatlantische inleiding. Antwerpen/Cambridge: Intersentia.

Fijnaut, C.J.C.F., Bovenkerk, F., Bruinsma, G. and Van de Bunt, H. (1998). Organized Crime in the Netherlands. Boston: Kluwer Law International.

Fijnaut, C.J.C.F. and Marx, G.T. (1995a). Introduction: The Normalization of Undercover Policing in the West: Historical and Contemporary Perspectives. In C.J.C.F. Fijnaut and G.T. Marx (eds.), Undercover: Police Surveillance in Comparative Perspective (pp. 1-27). The Hague: Kluwer.

Fijnaut, C.J.C.F. and Marx, G.T. (1995b). Undercover: Police Surveillance in Comparative Perspective. The Hague: Kluwer.

Financial Action Task Force (1999). Money Laundering. Policy Brief July 1999. Paris: FATF/OECD.

Financial Action Task Force (2014). Money Laundering. http://www.fatf-gafi.org/pages/faq/ moneylaundering. Accessed March 212014.

Fleming, M.H. (2008). An examination of the means of establishing the efficacy of asset recovery and anti-money laundering policies. $\mathrm{PhD}$ thesis. London: University of London.

Freiberg, A. and Fox, R.G. (2000). Evaluating the effectiveness of Australia's confiscation laws. Australian and New Zealand Journal of Criminology, 33(3): 239-265.

Frielink, P.M. (1990). Infiltratie in het strafrecht: Een onderzoek naar de materieelrechtelijke en formeelrechtelijke aspecten van het opsporen van strafbare feiten door middel van infiltratie. Arnhem: Gouda Quint.

Fulda, J. (2002). Do Internet Stings Directed at Pedophiles Capture Offenders or Create Offenders? And Allied Questions. Sexuality and Culture, 6: 73-100.

Fyfe, N. and Sheptycki, J. (2006). International Trends in the Facilitation of Witness Co-operation in Organized Crime Cases. European Journal of Criminology, 3(3): 319-355.

Gallant, M.M. (2005). Money Laundering and the Proceeds of Crime: Economic Crime and Civil Remedies. Cheltenham: Edward Elgar Publishing Limited.

Gambetta, D. and Reuter, P. (1995). Conspiracy among the many: the Mafia in legitimate industries. In G. Fiorentini and S. Peltzman (eds.), The Economics of Organised Crime (pp. 116-136). Cambridge: Cambridge University Press.

Garland, D. (2002). The Culture of Control. Crime and Social Order in Contemporary Society. Oxford: Oxford University Press. 
Gelemerova, L.Y. (2011). The anti-money laundering system in the context of globalisation: A panopticon built on quicksand? Nijmegen: Wolf Legal Publishers.

Gershman, B.L. (1982). Abscam, the Judiciary, and the Ethics of Entrapment. The Yale Law Journal, 91: 1565-1591.

Giacomantonio, C. (2011). Kouri T Keenan and Joan Brockman, Mr. Big: Exposing Undercover Investigations in Canada. Australian and New Zealand Journal of Criminology, 44(3): 452-455.

Gibbon, E. (1831), The History of the Decline and Fall of the Roman Empire. Volume 1. New York: Harper.

Girodo, M. (1991), 'Drug Corruption in Undercover Agents: Measuring the Risk', Behavioral Sciences and the Law, 9: 361-370.

Girodo, M., Deck, T. and Morrison, M. (2002). Dissociative-type identity disturbances in undercover agents: Socio-cognitive factors behind false-identity appearances and re-enactments. Social Behavior and Personality, 30(7): 631-644.

Goddard, H. (1957). Memoirs of a Bow Street Runner. New York: Morrow.

Government of the Netherlands (n.d.). Chain Programme Recovery. URL (accessed 10 February 2016): https://www.om.nl/algemeen/english/@87759/recovery/.

Grabosky, P. (2010). Perspectives on Criminal Investigation. Journal of Contemporary Criminal Justice, 26(4): 364-366.

Granovetter, M. (1985). Economic Action and Social Structure: The Problem of Embeddedness. American Journal of Sociology, 91: 481-510.

Greer, S. (2001). Where the grass is greener? Supergrases in comparative perspective. In R. Billingsley, T. Nemitz and P. Bean (eds.), Informers: policing, policy and practice (pp. 123140). Devon: Willan Publishing.

Groenhuijsen, M.S. and Kooijmans, T. (2011). Financial investigation and confiscation orders in a broader perspective: Developments in Dutch criminal law. In G.A. Antonopoulos, M.S., Groenhuijsen, J. Harvey, T. Kooijmans, A. Maljevic and K. Von Lampe (eds.), Usual and unusual organising criminals in Europe and beyond: Profitable crimes, from underworld to upper world, Liber Amicorum Petrus van Duyne (pp. 55-79). Apeldoorn/Antwerpen/Portland: Maklu.

Hale, C., Heaton, R. and Uglow, S. (2004). Uniform Styles? Aspects of Police Centralization in England and Wales. Policing and Society, 14(4): 291-312.

Harfield, C. (2008). Paradigms, Pathologies, and Practicalities - Policing Organized Crime in England and Wales. Policing, 2(1): 63-73.

Hobbs, B. (2013). Lush Life: Constructing Organised Crime in the UK. Oxford: Oxford University Press.

Hofmeyr, W. (2013). The effective use of asset recovery. Commonwealth Law Bulletin, 39(1): 59-63.

Hsu, S. (2012). The context of invisible finance. Crime, Law and Social Change, 57(3): 209-220 
Inspectie Openbare Orde en Veiligheid (2012). Follow the Money! Een onderzoek naar financieel opsporen door de politie in het licht van het landelijk programma FinEC Politie. Den Haag: Inspectie Openbare Orde en Veiligheid, Ministerie van Veiligheid en Justitie.

Joh, E.E. (2009). Breaking the Law to Enforce It: Undercover Police Participation in Crime. Stanford Law Review, 62: 155-199.

John, T. and Maguire, M. (2007). Criminal Intelligence and the National Intelligence Model. In T. Newburn, T. Williamson and A. Wright (eds.), Handbook of Criminal Investigation (pp. 176202). Cullompton: Willan Publishing.

Jongeneel-Van Amerongen, M. (1997). Centralization and Control of Undercover Police Operations. In M. Den Boer (ed.), Undercover Policing and Accountability from an International Perspective (pp. 59-64). Maastricht: European Institute of Public Administration.

Kennedy, A. (2007). An evaluation of the recovery of criminal proceeds in the United Kingdom. Journal of Money Laundering Control, 10(1): 33-46.

Kilchling, M. (2014). Finance-Oriented Strategies of Organized Crime Control. In L. Paoli (ed.), The Oxford Handbook of Organized Crime (pp. 655-673). Oxford: Oxford University Press.

Kim, S. and Skvoretz, J. (2013). Structural embeddedness, uncertainty, and international trade. International Journal of Comparative Sociology, 54(2): 124-143.

Kleemans, E.R. (2004). Crossing borders: Organized Crime in the Netherlands. In C. Fijnaut and L. Paoli (eds.), Organized Crime in Europe, Concepts, Patterns and Control Policies in the European Union and Beyond (pp. 303-331). Dordrecht/Norwell, Massachusetts: Springer.

Kleemans, E.R. (2007). Organized Crime, Transit Crime, and Racketeering. In M. Tonry and C. Bijleveld (eds.), Crime and Justice in the Netherlands. Crime and Justice. A Review of Rese arch. Volume 35 (pp. 163-215). Chicago: The University of Chicago Press.

Kleemans, E.R. (2012). Organized crime and the visible hand: A theoretical critique on the economic analysis of organized crime. Criminology and Criminal Justice, 13(5): 615-629 .

Kleemans, E.R. (2014a). Organized crime research: challenging assumptions and informing policy. In E. Cockbain and J. Knutsson (eds.), Applied Police Research: Challenges and Opportunities (Crime Science Series) (pp. 57-67). London / New York: Routledge.

Kleemans, E.R. (2014b). Theoretical perspectives on organized crime. In L. Paoli (ed.), Oxford Handbook of Organized Crime (pp. 32-52). Oxford: Oxford University Press.

Kleemans, E.R (2015). Follow the Money. Introduction to the Special Issue 'Financial Aspects of Organized Crime'. European Journal on Criminal Policy and Research, 21(2): 213-216.

Kleemans, E.R., Brienen, M.E.I., Van de Bunt, H.G., Kouwenberg, R.F., Paulides, G. and Barensen, J. (2002). Georganiseerde criminaliteit in Nederland: Tweede rapportage op basis van de WODC-monitor. Den Haag: WODC.

Kleemans, E.R. and De Poot, C.J. (2008). Criminal Careers in Organized Crime and Social Opportunity Structure. European Journal of Criminology, 5(1): 69-98.

Kleemans, E.R., De Poot, C.J. and Verhage, A. (2014). Criminologie en opsporing (redactioneel). Tijdschrift voor Criminologie, 56(4): 5-9. 
Kleemans, E.R. and Van de Bunt, H.G. (1999). The Social Embeddedness of Organized Crime. Transnational Organized Crime, 5(1): 19-36.

Kleemans, E.R., Van den Berg, E.A.I.M. and Van de Bunt, H.G. (1998). Georganiseerde criminaliteit in Nederland: Rapportage op basis van de WODC-monitor. Den Haag: WODC.

Klerks, P. (1995). Covert Policing in the Netherlands. In C.J.C.F. Fijnaut and G.T. Marx (eds.), Undercover: Police Surveillance in Comparative Perspective (pp. 1-27). The Hague: Kluwer.

KLPD (Korps landelijke politiediensten) (2008). Nationaal dreigingsbeeld 2008: Georganiseerde criminaliteit. Zoetermeer: KLPD, Dienst IPOL.

Kooijmans, T. and Borgers, M.J. (2012). Doorpakken bij het afpakken? Over de aftrek van kosten, de flexibilisering van het boeteplafond en de verhoging van de strafmaxima van de witwasdelicten, ter bestrijding van financieel-economische criminaliteit. Delikt en Delinkwent, 8: 683-701.

Kroeker, R.G. (2014). The pursuit of illicit proceeds: from historical origins to modern applications, Journal of Money Laundering Control, 17(3): 269-280.

Kruisbergen, E.W. (2013). Infiltrating organized crime groups. Theory, regulation and results of a last resort method of investigation, Cahier Politiestudies, 2013-3/28: 109-136.

Kruisbergen, E.W. and De Jong, D. (2010). Opsporen Onder Dekmantel: Regulering, Uitvoering en Resultaten van Undercovertrajecten. Meppel: Boom Juridische Uitgevers.

Kruisbergen, E.W., De Jong, D. and Kleemans, E.R. (2011). Undercover Policing: Assumptions and Empirical Evidence. British Journal of Criminology, 51(1): 394-412.

Kruisbergen, E.W., Kleemans, E.R. and De Jong, D. (2012). Controlling Criminal Investigations: The Case of Undercover Operations. Policing, 6(4): 398-407.

Kruisbergen E.W., Kleemans E.R. and Kouwenberg R.F. (2015a). Profitability, power, or proximity? Organized crime offenders investing their money in legal economy. European Journal on Criminal Policy and Research, 21(2): 237-256.

Kruisbergen, E.W., Kleemans, E.R. and Kouwenberg, R.F. (2015b). Wat doen daders met hun geld? Uitkomsten van de Monitor Georganiseerde Criminaliteit. Justitiële Verkenningen, 41(1): 84-102.

Kruisbergen, E.W., Kleemans, E.R. and Kouwenberg R.F. (2016). Explaining attrition: Investigating and confiscating the profits of organized crime. European Journal of Criminology, DOI: $10.1177 / 1477370816633262$.

Kruisbergen, E.W. and Soudijn, M.R.J. (2015). Wat is witwassen eigenlijk? Introductie tot theorie en praktijk. Justitiële Verkenningen, 41(1): 10-23.

Kruisbergen E.W., Van de Bunt, H.G. and Kleemans, E.R. (2012). Georganiseerde criminaliteit in Nederland. Vierde rapportage op basis van de Monitor Georganiseerde Criminaliteit. Meppel: Boom Lemma Uitgevers.

Kruissink, M., Van Hoorn, A.M. and Boek, J.L.M. (1999). Infiltratie in het Recht en in de Praktijk. Den Haag: Ministerie van Justitie. 
Langworthy, R.H. (1989). Do Stings Control Crime? An Evaluation of a Police Fencing Operation. Justice Quarterly, 6: 27-45.

Leeuw, F.L. (1991). Policy theories, knowledge utilization, and evaluation. Knowledge and Policy, 4: 73-92.

Leeuw, F.L. (2003). Reconstructing program theories: Methods available and problems to be solved. American Journal of Evaluation, 24(1): 5-20.

Levi, M. (2002). Money laundering and its regulation. Annals of the American Academy of Political and Social Science, 582(1): 181-194.

Levi, M. (2012). The Organization of Serious Crimes for Gain. In M. Maguire, R. Morgan and R. Steiner (eds.), The Oxford Handbook of Criminology (5th edition, pp. 595-622). Oxford: Oxford University Press.

Levi, M. (2013). Drug Law Enforcement and Financial Investigation Strategies. London: International Drug Policy Consortium.

Levi, M. (2014). Money Laundering. In: L. Paoli (ed.), The Oxford Handbook of Organized Crime (pp.419-443). Oxford: Oxford University Press.

Levi, M. and Reuter, P. (2009). Money Laundering. In M. Tonry (ed.), Handbook on Crime and Public Policy (pp. 356-380). New York: Oxford University Press.

Loftus, B. and Goold, B. (2011). Covert surveillance and the invisibilities of policing. Criminology and Criminal Justice, 12(/3): 275-288.

Loughran, T.A., Nguyen, H., Piquero, A.R. and Fagan, J. (2013). The Returns to Criminal Capital. American Sociological Review, 78(6): 925-948.

Lusty, D. (2002). Civil forfeiture of proceeds of crime in Australia. Journal of Money Laundering Control, 5(4): 345-359.

Macleod, A.D. (1995). Undercover Policing: A Psychiatrist Perspective. International Journal of Law and Psychiatry, 18: 239-247.

Maguire, M. and John, T. (1996). Covert and Deceptive Policing in England and Wales: Issues in Regulation and Practice. European Journal of Crime, Criminal Law and Criminal Justice, 4: 316-334.

Malm, A. and Bichler, G. (2013). Using friends for money: the positional importance of moneylaunderers in organized crime. Trends in Organized Crime, 16(4): 365-381.

Manning, P.K. (2008). Performance Rituals. Policing, 2(3): 284-293.

Martellozzo, E. (2012). Online Child Sexual Abuse: Grooming, Policing and Child Protection in a Multi-Media World. Abingdon: Routledge.

Marx, G.T. (1988). Undercover: Police Surveillance in America. Berkeley, Los Angeles, London: University of California Press.

Marx, G.T.(1992). Some Reflections on Undercover: Recent Developments and Enduring Issues. Crime, Law and Social Change, 18: 193-217. 
Marx, G.T. (1995). Undercover in Comparative Perspective: Some Implications for Knowledge and Social Research. In C.J.C.F. Fijnaut and G.T. Marx (eds.), Undercover: Police Surveillance in Comparative Perspective (pp. 323-337). The Hague: Kluwer.

Masciandaro, D., Takats, I. and Unger, B. (2007). Introduction. In D. Masciandaro, I. Takats and B. Unger (eds.), Black finance: the economics of money laundering (pp. ix-xx). Cheltenham: Edward Elgar.

Matrix Knowledge Group (2007). The illicit drug trade in the United Kingdom. Home Office Online Report 20/07. London: Home Office.

Meloen, J.D., Landman, R., De Miranda, H., Van Eekelen, J., Van Soest, S., Van Duyne, P.C. and Van Tilburg, W. (2003). Buit en besteding: Een empirisch onderzoek naar de omvang, de kenmerken en de besteding van misdaadgeld. Zoetermeer: Nationale Recherche Informatie.

Miller, L. (2006). Undercover Policing: A Psychological and Operational Guide. Journal of Police and Criminal Psychology, 21: 1-24.

Mitchell, K.J., Wolak, J. and Finkelhor, D. (2005). Police Posing as Juveniles Online to Catch Sex Offenders: Is It Working? Sexual Abuse: A Journal of Research and Treatment, 17: 241-267.

Morselli, C. (2009). Inside criminal networks. New York: Springer.

Murray, K. (2013). A square go: tackling organised crime where it doesn’t want to be tackled. Journal of Money Laundering Control, 16(2): 99-108.

Nationaal Rapporteur Mensenhandel en Seksueel Geweld tegen Kinderen (2014). Mensenhandel in en uit beeld II. Cijfermatige rapportage 2008-2012. Den Haag: Nationaal Rapporteur.

Naylor, R.T. (1999). Wash out: A critique of follow-the-money methods in crime control policy. Crime Law and Social Change, 32(1): 1-58.

Naylor, R.T. (2002). Wages of crime: Black markets, illegal finance, and the underworld economy. Ithaca: Cornell University Press.

Naylor, R.T. (2003). Follow-the-Money Methods in Crime Control Policy. In M.E. Beare (ed.), Critical Reflections on Transnational Organized Crime, Money Laundering, and Corruption (pp. 256-288). Toronto: University of Toronto Press.

Nelen, J.M. (2004). Hit them where it hurts most? The proceeds-of-crime approach in the Netherlands. Crime, Law and Social Change, 41(5): 517-534.

Nelen, J.M. and Sabee, V.(1998). Het Vermogente Ontnemen: Evaluatie van de Ontnemingswetgeving - Eindrapport. Den Haag: WODC.

Newburn, T., Williamson, T. and Wright, A. (2007). Governance of Criminal Investigation. In T. Newburn, T. Williamson and A. Wright (eds.), Handbook of Criminal Investigation (pp. 547548). Cullompton: Willan Publishing.

Newman, G.R. (2007). Sting operations. Problem-oriented guides for police response guides, no. 6. Washington, DC: U.S. Department of Justice.

Neyroud, P. and Disley, E. (2007). The Management, Supervision and Oversight of Criminal Investigations. In T. Newburn, T. Williamson and A. Wright (eds.), Handbook of Criminal Investigation (pp. 549-571). Cullompton, UK: Willan Publishing. 
Noorlander, P. (1998). The impact of the human rights act 1998 on covert policing: Principles and practice. The International Journal of Human Rights, 3(4): 49-66.

Odinot, G., De Jong, D., Van der Leij, J.B.J., De Poot, C.J. and Van Straalen, E.K. (2012). Het gebruik van de telefoon- en internettap in de opsporing. Meppel: Boom Lemma Uitgevers.

Openbaar Ministerie (2014) Jaarbericht 2013. Den Haag: Openbaar Ministerie.

Openbaar Ministerie (2015). Jaarbericht 2014. Den Haag: Openbaar Ministerie.

Openbaar Ministerie (2016). Jaarbericht 2015. Den Haag: Openbaar Ministerie.

Openbaar Ministerie and Politie (2015). Verantwoording aanpak georganiseerde criminaliteit 2014. Den Haag: Openbaar Ministerie.

Paoli L. (2014) Introduction. In L. Paoli (ed.), The Oxford Handbook of Organized Crime (pp. 545571). Oxford: Oxford University Press.

Paoli, L. and Fijnaut, C.J.C.F. (2004a). Introduction to Part I: The History of the Concep. In C.J.C.F. Fijnaut and L. Paoli (eds.), Organized Crime in Europe, Concepts, Patterns and Control Policies in the European Union and Beyond (pp. 21-46). Dordrecht/Norwell, Massachusetts: Springer.

Paoli, L. and Fijnaut, C.J.C.F. (2004b). General Conclusion. In C.J.C.F. Fijnaut and L. Paoli (eds.), Organized Crime in Europe, Concepts, Patterns and Control Policies in the European Union and Beyond (pp. 1043-1044). Dordrecht/Norwell, Massachusetts: Springer.

Paoli, L. and Fijnaut, C.J.C.F. (2004c). Comparative Synthesis of Part II. In C.J.C.F. Fijnaut and L. Paoli (eds.), Organised Crime in Europe. Concepts, Patterns and Control Policies in the European Union and Beyond (pp. 603-621). Dordrecht/Norwell, Massachusetts: Springer.

Paoli L. and Fijnaut, C.J.C.F. (2006). Organised crime and its control policies in Europe. European Journal of Crime, Criminal Law and Criminal Justice, 14(3): 307-327

PEO (Parlementaire Enquêtecommissie Opsporingsmethoden) (1996). Inzake opsporing: Enquête opsporingsmethoden.

Eindrapport. Den Haag: Sdu: Uitgevers.

Bijlage V: Opsporingsmethoden. Den Haag: Sdu: Uitgevers.

Bijlage X: deelonderzoek III onderzoeksgroep Fijnaut: De georganiseerde criminaliteit in Nederland: de vrije beroepsbeoefenaren: advocaten, notarissen, accountants; fraude en witwassen. Den Haag: Sdu: Uitgevers.

Petrunov, G. (2011). Managing money acquired from human trafficking: case study of sex trafficking from Bulgaria to Western Europe. Trends in Organized Crime, 14: 165-186.

Pollitt, C. (1993). Managerialism and the Public Services. Oxford: Blackwell Publishers.

Puddister, K. and Riddell, T. (2012). The RCMP's 'Mr. Big' sting operation: A case study in police independence, accountability and oversight. Canadian public administration, 55(3): 385-409.

Reijne, Z., Kouwenberg, R.F. and Keizer, M.P. (1996). Tappen in Nederland. Arnhem: Gouda Quint.

Reuter, P. (1983). Disorganized Crime: The Economics of the Visible Hand. Cambridge: MIT Press. Reuter, P. and Truman, E.M. (2005). Money Laundering Controls and Terrorist Finance. Financial Regulator, 10(2): 35-37. 
Riccardi, M. (2014). When Criminals Invest in Businesses: Are We Looking in the Right Direction? An Exploratory Analysis of Companies Controlled by Mafias. In S. Caneppele and F. Calderoni (eds.), Organized Crime, Corruption and Crime Prevention Essays in Honor of Ernesto U. Savona (pp. 197-206). Cham: Springer.

Roberts, A. (2000). Crime Creation? Some Questions of Fairness and Efficacy in Covert Operations. The Police Journal, 73: 263-276.

Roberts, P. (2007). Law and Criminal Investigation. In T. Newburn, T. Williamson and A. Wright (eds.), Handbook of Criminal Investigation (pp. 92-145). Cullompton: Willan Publishing.

Ross, J.E. (2004). Impediments to Transnational Cooperation in Undercover Policing: A Comparative Study of the United States and Italy. The American Journal of Comparative Law, 52: 569-623.

Ross, J.E. (2007). The Place of Covert Surveillance in Democratic Societies: A Comparative Study of the United States and Germany. The American Journal of Comparative Law, 55: 493-579.

Ross, J.E. (2008). Undercover Policing and the Shifting Terms of Scholarly Debate: The United States and Europe in Counterpoint. Annual Review of Law and Social Science, 4: 239-273.

Savona, E.U. (2015). The Businesses of Italian Mafias. European Journal on Criminal Policy and Research, 21(2): 217-236.

Schneider, F. (2010). Turnover of organized crime and money laundering: some preliminary empirical findings. Public Choice, 144(3): 473-486.

Schneider, F. and Windischbauer, U. (2008). Money laundering: Some facts. European Journal of Law and Economics, 26(3): 387-404.

Schneider, S. (2004). Money laundering in Canada: an analysis of RCMP cases. Toronto: Nathanson Centre for the Study of Organized Crime and Corruption, York University.

Shelley, L. (2006). The Globalization of Crime and Terrorism. eJjournal USA, The Challenges of Globalization, 11(1): 42-45.

Sherman, L.W. (2013). The rise of evidence-based policing: targeting, testing, and tracking. Crime Justice, 42(1): 377-451.

Sieber, U. and Bögel, M. (1993). Logistik der Organisierten Kriminalität. Wiesbaden: Bundeskriminalamt.

Slot, B., De Swart, L., Deleanu, I., Merkus, E, Levi, M. and Kleemans, E.R. (2015). Needs assessment on tools and methods of financial investigation in the European Union. Rotterdam: Ecorys.

Smith, S.M., Stinson, V. and Patry, M.W. (2009). Using the the 'Mr. Big' technique to elicit confessions: Successful innovation or dangerous development in the Canadian legal system? Psychology, Public Policy, and Law, 15(3): 168-193.

Soudijn, M.R.J. (2011). Geen smoesjes meer: De strategie van 'removing excuses' toegepast op financiële facilitators. Justitiële verkenningen, 37(2): 40-57.

Soudijn, M.R.J. and Akse, Th. (2012). Witwassen. Criminaliteitsbeeldanalyse 2012. Driebergen: KLPD, Dienst Nationale Recherche. 
Spapens, A.C. (2006). Interactie tussen criminaliteit en opsporing: De gevolgen van opsporingsactiviteiten voor de organisatie en afscherming van xtc-productie en -handel in Nederland. Antwerpen: Intersentia.

Sproat, P.A. (2007). An evaluation of the UK's anti-money laundering and asset recovery regime. Crime, Law and Social Change, 47(3): 169-184.

Sproat, P.A. (2009). Payback time? To what extent has the new policing of assets provided new assets for policing? Journal of Money Laundering Control, 12(4): 392-405.

Stuesser, L. (2008). 'Mr Big' comes to Australia. The National Legal Eagle, 14(1): 1-4.

Suendorf, U. (2001). Geldwäsche: eine kriminologische Untersuchung. Luchterhand: Neuwied und Kriftel.

Terpstra, J. (2011). Governance and Accountability in Community Policing. Crime, Law and Social Change, 55(2-3): 87-104.

Terpstra, J. and Van der Vijver, K. (2005). Het Nederlandse politiebestel en de druk tot centralisatie. Tijdschrift voor Criminologie, 47(4): 335-344.

Traest, P. and Meese, J. (2000). België. In Tak, P.J.P. (ed.), Heimelijke opsporing in de Europese Unie: De normering van bijzondere opsporingsmethoden in de landen van de Europese Unie (pp. 9-65). Antwerpen, Groningen: Intersentia Rechtswetenschappen.

Transcrime (2013). Progetto PON Sicurezza 2007-2013. Gli investimenti delle mafie, Summary. www.investimentioc.it. Accessed April 272014.

Transparency International (2012). Transparency International Corruption Perceptions Index 2012. Berlin: Transparency International International Secretariat.

U.S. Senate (1951). Final report of the special committee to investigate organized crime in interstate commerce (Kefauver Committee). 82ND Congress, 1st Session. Washington: U.S. Government Printing Office.

Unger, B. (2008). Effectiviteit van anti-witwasbeleid in Nederland. Economisch Statistische Berichten, 93(4543S): 45-50.

Unger, B., Siegel, M., Ferwerda, J., De Kruijf, W., Busuioic, M., Wokke, K. and Rawlings, G. (2006). The amounts and the effects of money laundering. Report for the Ministry of Finance, February 16, 2006. Utrecht: Utrecht School of Economics; Canberra, Australia: Australian National University.

United Nations (1988). United Nations Convention against Illicit Traffic in Narcotic Drugs and Psychotropic Substances. Vienna: United Nations.

UNODC (United Nations Office on Drugs and Crime) (2011). Estimating illicit financial flows resulting from drug trafficking and other transnational organized crimes. Vienna: UNODC.

UNODC (United Nations Office on Drugs and Crime) (2015). World Drug Report 2015. Vienna: UNODC.

Uzi, B. and Lancaster, R. (2004). Embeddedness and Price Formation in the Corporate Law Market. American Sociological Review, 69(3): 319-344. 
Van de Bunt, H. (2004). Organised Crime Policies in the Netherlands. In C.J.C.F. Fijnaut and L. Paoli (eds.), Organized Crime in Europe, Concepts, Patterns and Control Policies in the European Union and Beyond (pp. 677-716). Dordrecht/Norwell, Massachusetts: Springer.

Van de Bunt, H.G. (2007). Muren van Stilzwijgen. In H.G. van de Bunt, P. Spierenburg and R. van Swaaningen (eds.), Drie perspectieven op sociale controle (pp. 133-136). Den Haag: Boom Juridische Uitgevers.

Van de Bunt, H.G. (2010). Walls of secrecy and silence: The Madoff case and cartels in the construction industry. Criminology and Public Policy, 9(3): 435-453.

Van de Bunt, H.G. and Kleemans, E.R. (2007). Georganiseerde criminaliteit in Nederland: Derde rapportage op basis van de Monitor Georganiseerde Criminaliteit. Den Haag: Boom Juridische uitgevers.

Van de Bunt, H.G. and Van der Schoot, C.R.A. (eds.) (2003). Prevention of organized crime: A situational approach. Den Haag: Boom Juridische uitgevers.

Van der Schoot, C.R.A. (2006). Organised Crime Prevention in the Netherlands: Exposing the Effectiveness of Preventive Measures. Den Haag: Boom Juridische Uitgevers.

Van der Tak, P.J.P. (2000). Inleiding. In P.J.P. Tak (ed.), Heimelijke opsporing in de Europese Unie: De normering van bijzondere opsporingsmethoden in de landen van de Europese Unie (pp. 207298). Antwerpen, Groningen: Intersentia Rechtswetenschappen.

Van der Vorm, B. (2016). Ernstig gevaar: Een juridisch-empirisch onderzoek naar aard, doel en toepassing van de Wet Bibob. Oisterwijk: Wolf Legal Publishers

Van Duyne, P.C. (2003). Money laundering policy. Fears and facts. In P.C. van Duyne, K. von Lampe and J.L. Newell (eds.), Criminal finances and organising crime in Europe (pp. 67-104). Nijmegen: Wolf Legal Publishers.

Van Duyne, P.C. (2013). Crime-money and financial conduct. In B. Unger and D. van der Linde (eds.), Research handbook on Money laundering (pp. 232-250). Cheltenham: Edward Elgar.

Van Duyne, P.C. and De Miranda, H. (1999). The emperor's cloths of disclosure: hot money and suspect disclosures. Crime, Law and Social Change, 31(3): 245-271.

Van Duyne, P.C, De Zanger, W.S. and Kristen, F.G.H. (2014). Greedy of crime money. The reality and ethics of asset recovery. In P.C. van Duyne (ed.), Corruption, Greed and Crime Money: Sleaze and Shady Economy in Europe and beyond (pp. 235-266). Oisterwijk: Wolf Legal Publishers.

Van Duyne, P.C. and Levi, M. (2005). Drugs and Money: Managing the Drug Trade and Crimemoney in Europe. Abingdon: Routledge.

Van Duyne, P.C., Pheijffer, M., Kuijl, H.G., Van Dijk, A.T.M. and Bakker, G.J.C.M. (2001). Financial Investigation of Crime. Den Haag: Koninklijke Vermande.

Van Duyne, P.C. and Soudijn, M.R.J. (2009). Hot money, hot stones and hot air: crime-money threat, real estate and real concern. Journal of Money Laundering Control, 12(2): 173-188.

Van Duyne, P.C. and Soudijn, M.R.J. (2010). Crime-money in the financial system: what we fear and what we know. In M. Herzog-Evans (ed.), Transnational Criminology Manual (pp. 253-279). Nijmegen: Wolf Legal. 
Van Duyne, P.C. and Vander Beken, T. (2009). The incantations of the EU organised crime policy making. Crime, Law and Social Change, 51(2): 261-281.

Van Gestel, B. (2010). Mortgage fraud and facilitating circumstances. In K. Bullock, R.V. Clarke and N. Tilly (eds.), Situational prevention of organised crimes (pp. 111-129). Cullompton: Willan.

Van Koppen, M.V. (2013a). Pathways into organized crime: Criminal opportunities and adultonset offending. Amsterdam: Vrije Universiteit.

Van Koppen, M.V. (2013b). Involvement mechanisms for organized crime. Crime, Law and Social Change, 59(1): 1-20.

Van Koppen, M.V., De Poot, C.J., Kleemans, E.R. and Nieuwbeerta, P. (2010). Criminal Trajectories in Organized Crime. British Journal of Criminology, 50(1): 102-123.

Van Oss, G. (1994). De undercoveragent: Problemen van normafwijking, corruptie en controle. Lelystad: Koninklijke Vermande.

Van Thiel, S. and Leeuw, F.L. (2002). The Performance Paradox in the Public Sector. Public Performance and Management Review, 25: 267-281.

Van Traa, M. (1997). The Findings of the Parliamentary Inquiry Viewed from a International Perspective. In M. den Boer (ed.), Undercover Policing and Accountability from an International Perspective (pp. 15-24). Maastricht: European Institute of Public Administration.

Verhage, A. (2009). Between the hammer and the anvil? The anti-money laundering-complex and its interactions with the compliance industry. Crime, Law and Social Change, 52(1): 9-32.

Verhage, A. (2011). The anti-Money laundering Complex and the Compliance Industry. Abingdon: Routledge.

Vettori, B. (2006). Tough on Criminal Wealth: Exploring the Practice of Proceeds from Crime Confiscation in the EU. Dordrecht: Springer.

Von Lampe, K. (2001). Not a process of enlightenment: the conceptual history of organized crime in Germany and the United States of America. Forum on Crime and Society, 1(2): 99-116.

Vruggink, J.C. (2001). Gepakt en gezakt: Invloed van de ontnemingsmaatregel op daders. Leiden.

Wachtel, J. (1992). From Morals to Practice: Dilemmas of Control in Undercover Policing. Crime, Law and Social Change, 18: 137-158.

Wagner, G.A. (2007). United States' Policy Analysis on Undercover Operations. International Journal of Police Science and Management, 9: 371-380.

Walker, J. (1999). How big is global money laundering? Journal of Money Laundering Control, 3(1): 25-37.

Walsh, D.P.J. and Conway, V. (2011). Police Governance and Accountability: Overview of Current Issues. Crime, Law and Social Change, 55(2-3): 241-257.

Webb, S. and Burrows, J. (2009). Organised immigration crime: a post-conviction study, Home Office Research Report 15. London: Home office.

Webster, D.W., Bulzacchelli, M.T. and Vernick, J.S. (2006). Effects of Undercover Police Stings of Gun Dealers on the Supply of New Guns to Criminals. Injury Prevention, 12: 225-230. 
WEF (World Economic Forum) (2011). Global Agenda Council on Organized Crime. 2010-2011 Term report. Geneva: World Economic Forum.

Worrall, J.L. and Kovandzic, T.V. (2008). Is policing for profit? Answers from asset forfeiture. Criminology and Public Policy, 7(2): 219-244.

\section{Newspapers}

Voskuil, K. (2016). Politie lokt crimineel vaker in val. Algemeen Dagblad, 2016, May 18: 1.

\section{Case law}

EHRM, 15 juni 1992, LJN AC4221 m.nt. E.E.Alkema (Lüdi tegen Zwitserland).

EHRM, 23 april 1997, LJN AD4540 (Van Mechelen tegen Nederland).

EHRM, 09 juni 1998, LJN AD4193 (Teixeira de Castro tegen Portugal).

EHRM, 15 december 2005, LJN AV3573 (Vanyan tegen Rusland).

EHRM, 26 oktober 2006, LJN AZ6230 (m.nt. F.P. Ölçer (Khudobin tegen Russia)).

EHRM, 5 februari 2008, LJN BC8752 (Ramanauskas tegen Litouwen)).

Hoge Raad, 04 december 1979, LJN AB7429 (m.nt. Th.W. van Veen (Tallon)).

Hoge Raad, 17 september 1981, NJ 1981, 536 (m.nt. G.E. Mulder).

Hoge Raad, 17 januari 1984, LJN AC8248.

Hoge Raad, 24 oktober 1989, LJN ZC8256.

Hoge Raad, 04 december 1990, LJN AB8965.

Hoge Raad, 5 december 1995, LJN ZD0315

Hoge Raad, 19 december 1995, LJN ZD0328, m.nt. T.M. Schalken (Zwolsman).

Hoge Raad, 14 maart 2000, LJN ZD1649

Hoge Raad, 26 september 2000, LJN AA7233 (m.nt. T.M. Schalken)

Hoge Raad, 14 november 2000, LJN AA8295.

Hoge Raad, 23 januari 2001, LJN ZD2194 (m.nt. Y. Buruma).

Hoge Raad, 2 juli 2002, LJN AD9915.

Hoge Raad, 15 oktober 2002, LJN AE7668.

Hoge Raad, 4 februari 2003, LJN AE9069.

Hoge Raad, 7 oktober 2003, LJN AG2528.

Hoge Raad, 9 maart 2004, LJN AN9195.

Hoge Raad, 23 november 2004, LJN AQ8478.

Hoge Raad, 12 april 2005, LJN AS5843.

Hoge Raad, 28 maart 2006, LJN AU5471.

Hoge Raad, 18 april 2006, LJN AV2377.

Hoge Raad, 28 oktober 2008, LJN BE9817.

Gerechtshof Amsterdam, 2 februari 1979, LJN AB7252. 
Gerechtshof Amsterdam, 25 maart 1991, LJN AD1363.

Gerechtshof Amsterdam, 26 juni 2002, LJN AE7045.

Gerechtshof Amsterdam, 28 januari 2008, LJN BC5069.

Gerechtshof Arnhem, 30 juni 1989, LJN AD0852.

Gerechtshof Arnhem, 12 mei 2003, LJN AF8395.

Gerechtshof 's-Gravenhage, 12 april 2002, LJN AE4747.

Gerechtshof 's-Gravenhage, 15 mei 2002, LJN AE4754.

Gerechtshof 's-Gravenhage, 12 november 2002, LJN AF0783.

Gerechtshof 's-Gravenhage, 11 juli 2003, LJN AH9732.

Gerechtshof 's-Gravenhage, 26 september 2003 LJN AN7589.

Gerechtshof 's-Gravenhage, 21 november 2003, LJN AN8750.

Gerechtshof 's-Gravenhage, 21 november, 2003, LJN AN8752.

Gerechtshof 's-Gravenhage, 4 maart 2005, LJN AS9042.

Gerechtshof 's-Gravenhage, 29 september 2006, LJN AZ0109.

Gerechtshof 's-Hertogenbosch, 14 februari 2001, LJN AB0272.

Gerechtshof 's-Hertogenbosch, 03 augustus 2001, LJN AF4420.

Gerechtshof 's-Hertogenbosch, 3 juni 2003, LJN AO9091.

Gerechtshof 's-Hertogenbosch, 23 juli 2003, LJN AO9528.

Gerechtshof 's-Hertogenbosch, 26 september 2003, LJN AN7589.

Gerechtshof 's-Hertogenbosch, 31 oktober 2003, LJN AP0289.

Gerechtshof 's-Hertogenbosch, 19 december 2003, LJN AP0560.

Gerechtshof 's-Hertogenbosch, 25 april 2005, LJN AT5241.

Gerechtshof 's-Hertogenbosch, 29 november 2006, LJN AZ4125.

Gerechtshof 's-Hertogenbosch, 9 mei 2008, LJN BD8152.

Rechtbank Almelo, 18 september 2007, LJN BB3740.

Rechtbank Amsterdam, 22 maart 1978, LJN AC6223.

Rechtbank Amsterdam, 20 september 1978, LJN AC6350.

Rechtbank Amsterdam, 8 november 2001, LJN AD5311.

Rechtbank Amsterdam, 27 april 2007, LJN BA4017.

Rechtbank Assen, 13 december 2002, LJN AF1854.

Rechtbank Breda, 04 februari 2002, LJN AD9165.

Rechtbank Breda, 24 december 2002, LJN AF3743.

Rechtbank Breda, 26 oktober 2004, LJN AR4560.

Rechtbank Dordrecht, 22 maart 2006, LJN AX 0773.

Rechtbank 's-Gravenhage, 23 november 2001, LJN AD6065.

Rechtbank Roermond, 23 december 2005, LJN AU8633.

Rechtbank Rotterdam, 30 januari 1991, LJN AD1325.

Rechtbank Rotterdam, 14 juni 2002, LJN AE4239.

Rechtbank Rotterdam, 30 september 2003, LJN AN7719. 
Rechtbank Rotterdam, 11 augustus 2006, LJN AY6630.

Rechtbank Rotterdam, 19 december 2006, LJN AZ8683.

Rechtbank Utrecht, 03 april 2008, LJN BC8607.

Rechtbank Zwolle 03 mei 2007, LJN BA4345.

\section{Legislation and parliamentary documents}

Council Directive 91/308/EEC of 10 June 1991 on prevention of the use of the financial system for the purpose of money laundering (Official Journal L 166 of 28.06.1991).

Directive 2001/97/EC Directive 2001/97/EC of the European Parliament and of the Council of 4 December 2001 amending Council Directive 91/308/EEC on prevention of the use of the financial system for the purpose of money laundering.

Directive 2005/60/EC Directive 2005/60/EC of the European Parliament and of the Council of 26 October 2005 on the prevention of the use of the financial system for the purpose of money laundering and terrorist financing.

Directive (EU) 2015/849 of the European Parliament and of the Council of 20 May 2015 on the prevention of the use of the financial system for the purposes of money laundering or terrorist financing, amending Regulation (EU) No 648/2012 of the European Parliament and of the Council, and repealing Directive 2005/60/EC of the European Parliament and of the Council and Commission Directive 2006/70/EC.

House of Commons, Committee of Public Accounts (2014). Confiscation Orders, Forty-ninth Report of Session 2013-14 (HC 942). London: The Stationery Office.

Minister van Veiligheid en Justitie (2013). Beantwoording Kamervragen over megaschikking met een oliehandelaar en het afkopen van strafvervolging, brief, kenmerk 4263 12. Den Haag: Ministerie van Veiligheid en Justitie.

Minister van Veiligheid en Justitie (2015). Antwoorden Kamervragen over misdaadgeld en de werkelijkheid van voordeelsontneming, brief, kenmerk 6268 55. Den Haag: Ministerie van Veiligheid en Justitie.

Minister van Veiligheid en Justitie (2016). Aanpak Misbruik Vastgoed, brief, kenmerk 721273.

Den Haag: Ministerie van Veiligheid en Justitie.

Tweede Kamer, vergaderjaar 1989-1990, 21 504, no. 3.

Tweede Kamer, vergaderjaar 1996-1997, 25 403, no. 3.

Tweede Kamer, vergaderjaar 1999-2000, 27 159, no. 3.

Tweede Kamer, vergaderjaar 2002-2003, 27 834, no. 28.

Tweede Kamer, vergaderjaar 2008-2009, 30 517, no. 13.

Tweede Kamer, vergaderjaar 2011-2012, 29 911, no. 56, 57.

Tweede Kamer, vergaderjaar 2012-2013, 29 911, no. 83.

Tweede Kamer, vergaderjaar 2012-2013, 33 685, no. 3. 
Wet van 10 december 1992 tot wijziging van het Wetboek van Strafrecht en het Wetboek van Strafvordering en enkele andere wetten ter verruiming van de mogelijkheden tot toepassing van de maatregel van ontneming van wederrechtelijk verkregen voordeel en andere vermogenssancties, Stb. 1993, no. 11.

Wet van 16 december 1993 houdende nieuwe bepalingen inzake identificatie van cliënten bij financiële dienstverlening (Wet identificatie bij financiële dienstverlening 1993), Stb. 1993, no. 704.

Wet van 16 december 1993 betreffende melding ongebruikelijke transacties bij financiële dienstverlening (Wet melding ongebruikelijke transacties), Stb. 1993, no. 705.

Wet van 27 mei 1999 tot wijziging van het Wetboek van Strafvordering in verband met de regeling van enige bijzondere bevoegdheden tot opsporing en wijziging van enige andere bepalingen (bijzondere opsporingsbevoegdheden), Stb. 1999, no. 245.

Wet van 6 december 2001 tot wijziging van het Wetboek van Strafrecht en enkele andere wetten in verband met de strafbaarstelling van het witwassen van opbrengsten van misdrijven, Stb. 2001, no. 606 .

Wet van 20 juni 2002, houdende regels inzake de bevordering van integriteitsbeoordelingen door het openbaar bestuur met betrekking tot beschikkingen of overheidsopdrachten (Wet bevordering integriteitsbeoordelingen door het openbaar bestuur), Stb. 2002, no. 347.

Wet van 8 mei 2003 tot wijziging en aanvulling van een aantal bepalingen in het Wetboek van Strafrecht, het Wetboek van Strafvordering en enige andere wetten met betrekking tot de ontneming van wederrechtelijk verkregen voordeel (aanpassing ontnemingswetgeving), Stb. 2003, no. 202.

Wet van 31 maart 2011 tot wijziging van het Wetboek van Strafrecht, het Wetboek van Strafvordering en enige andere wetten ter verbetering van de toepassing van de maatregel ter ontneming van wederrechtelijk verkregen voordeel (verruiming mogelijkheden voordeelontneming), Stb. 2011, no. 171 .

Wet van 19 november 2014 tot wijziging van het Wetboek van Strafrecht, het Wetboek van Strafvordering en de Wet op de economische delicten met het oog op het vergroten van de mogelijkheden tot opsporing, vervolging, alsmede het voorkomen van financieel-economische criminaliteit (verruiming mogelijkheden bestrijding financieel-economische criminaliteit), Stb. 2014, no. 445 . 


\section{Samenvatting (Dutch summary)}

\section{Bestrijding van georganiseerde criminaliteit: Een onderzoek naar undercoveroperaties en de financiële aanpak}

De bestrijding van georganiseerde criminaliteit is regelmatig onderwerp van, soms hevig, academisch en politiek-maatschappelijk debat. De hoeveelheid beschikbare feitelijke informatie over dit onderwerp is echter beperkt. De debatten lijken dan ook vaak meer door normatieve stellingnames dan door empirisch inzicht te worden gestuurd. Het doel van dit proefschrift is het vergroten van het empirisch inzicht in de georganiseerde criminaliteit en vooral haar bestrijding. We richten ons op twee vormen van bestrijding van georganiseerde criminaliteit: de strafrechtelijke aanpak en de financiële aanpak ('follow the money'). Voor wat betreft de strafrechtelijke aanpak concentreert dit proefschrift zich op door de politie uitgevoerde undercoveroperaties (hoofdstuk 2 en 3). Voor de financiële aanpak kijken we naar wat daders eigenlijk doen met hun geld (hoofdstuk 4) alsook naar de uitvoeringspraktijk van een maatregel die is bedoeld om criminele inkomsten af te pakken, de ontnemingsmaatregel (hoofdstuk 5). De Nederlandse samenvatting die u nu leest is een vrijwel integrale vertaling van het afsluitende hoofdstuk 'Conclusion and discussion' (hoofdstuk 6). Hieronder worden allereerst de onderzoeksvragen, gebruikte databronnen en de belangrijkste empirische uitkomsten besproken (paragraaf S.1). Vervolgens bespreken we de sterke alsook de methodologisch zwakkere punten van dit proefschrift (paragraaf S.2), verkennen we de mogelijke implicaties voor het beleid (paragraaf S.3) en doen we suggesties voor verder onderzoek (paragraaf S.4).

\section{S.1 Onderzoeksvragen, databronnen en empirische resultaten}

\section{S.1.1 De strafrechtelijke aanpak}

Undercoveroperaties zijn een van de meest controversiële opsporingsmethoden. Het is ook een opsporingsmethode (althans een specifieke vorm ervan) die aan de basis lag van de IRTaffaire, welke een bepalende invloed heeft gehad op het debat rondom opsporingsmethoden. Zowel de eerste als de tweede set onderzoeksvragen richt zich op door de politie uitgevoerde undercoveroperaties (de inzet van burgers in undercoveroperaties valt hierbuiten). ${ }^{167}$

${ }_{167}$ Zie Kruisbergen en De Jong (2010) voor een meer uitgebreide Nederlandstalige toelichting. 


\section{Undercoveroperaties: algemeen overzicht van undercoveroperaties in 2004}

Het Nederlandse Wetboek van Strafvordering maakt onderscheid tussen drie undercoverbevoegdheden: het stelselmatig inwinnen van informatie; de pseudo-koop of -dienstverlening; en infiltratie. De eerste set onderzoeksvragen richt zich op undercoveroperaties in het algemeen, dat wil zeggen Nederlandse opsporingsonderzoeken waarin in 2004 is overwogen om een of meerdere undercoverbevoegdheden in te zetten.

- Hoe vaak worden undercoveroperaties ingezet?

- Welke verschillende soorten undercoveroperaties zijn er?

- Welke resultaten hebben deze undercoveroperaties opgeleverd?

Voor de beantwoording van deze vragen zijn verschillende informatiebronnen gebruikt. Van politiële infiltratieteams is informatie verkregen over Nederlandse opsporingsonderzoeken ten behoeve waarvan in 2004 contact is opgenomen met een infiltratieteam en waarin de inzet van een undercoveroperatie is overwogen. ${ }^{168}$ Daarnaast is voor alle opsporingsonderzoeken waarin een undercoveroperatie ook daadwerkelijk is ingezet, de officier van justitie en/of teamleider van de politie telefonisch geïnterviewd. Verder is Nederlandse jurisprudentie aangaande het gebruik van undercoveroperaties bestudeerd.

In 2004 is de inzet van een undercoveroperatie overwogen in 89 Nederlandse opsporingsonderzoeken. ${ }^{169}$ In 52 zaken is uiteindelijk besloten dat de inzet van een undercoveroperatie niet mogelijk of niet (meer) nodig was. In 37 opsporingsonderzoeken is besloten om wel een undercoveroperatie in te zetten, maar in 3 van deze zaken werd afgezien van inzet van de operatie nog voordat die van start was gegaan. In 34 opsporingsonderzoeken zijn dus daadwerkelijk een of meer undercoveragenten ingezet. In al deze gevallen ging het om de toepassing van het stelselmatig inwinnen van informatie en/of pseudo-koop of -dienstverlening; geen enkele keer betrof het infiltratie.

Undercoveroperaties, in ieder geval in de onderzochte periode, worden dus niet vaak toegepast. Ter vergelijking: in 2008 zijn 26.425 Nederlandse telefoonnummers getapt (Tweede Kamer, 2008-2009, 30 517, nr. 13). Een verklaring voor het relatief geringe gebruik van undercoveroperaties zou kunnen zijn dat undercoveroperaties, vooral wanneer

168 Undercoveroperaties in het kader van internationale rechtshulpverzoeken zijn niet meegenomen.

169 We verzamelden informatie van de vijf operationele politiële infiltratieteams omtrent alle 37 opsporingsonderzoeken ten behoeve waarvan in 2004 contact is opgenomen met een infiltratieteam en waarin is besloten om een undercoveroperatie in te zetten. Vier van de vijf politiële infiltratieteams konden ook informatie aanleveren met betrekking tot 46 opsporingsonderzoeken waarin het raadplegen van het infiltratieteam uitmondde in de beslissing om géén undercoveroperatie in te zetten. Aangenomen dat de verhouding tussen positieve en negatieve beslissingen (wel/geen inzet undercoveroperatie) zoals die bij deze vier infiltratieteams ligt ook geldt voor het vijfde infiltratieteam, komt het totale aantal negatieve beslissingen op 52, wat het totale aantal opsporingsonderzoeken waarin de inzet van een undercoveroperatie is overwogen op $(37+52=) 89$ brengt (zie hoofdstuk 1). 
het om infiltratie gaat, pas worden gebruikt wanneer andere opsporingsmethoden hebben gefaald, hoewel de wetgeving niet voorschrijft dat undercoveroperaties in het algemeen uitsluitend als laatste redmiddel mogen worden ingezet. Andere mogelijke redenen zijn: het ontbreken van de behoefte om het middel vaker in te zetten; een beperkte kennis van en ervaring met undercoveroperaties; terughoudendheid om undercoveroperaties in te zetten als gevolg van de IRT-affaire en haar nasleep; en terughoudendheid vanwege de vereiste autorisatieprocedures, vooral in het geval van infiltratie (zie de tweede set van onderzoeksvragen).

Undercoveroperaties variëren sterk wat betreft hun duur, intensiteit en het soort contact tussen undercoveragent en subject. Sommige operaties bestaan uit niet meer dan een kort zakelijk contact tussen undercoveragent en het subject en duren niet langer dan een dag. Er zijn echter ook undercoveroperaties die langer dan een jaar duren en uit vele contacten bestaan. Het soort contact verschilt ook. Contacten kunnen vooral zakelijk van aard zijn, zoals in veel opsporingsonderzoeken die zich richten op drugs of wapens. Maar soms moet een undercoveragent juist een vrij hechte persoonlijke en emotionele band opbouwen met een subject, zoals in een zaak waarin een undercoveragent 'bevriend' moet raken met een subject om informatie te vergaren over zijn betrokkenheid bij een moord.

Verder hebben we gekeken naar de resultaten die undercoveroperaties voor een opsporingsonderzoek genereren. In 7 van de 34 opsporingsonderzoeken leverde de undercoveroperatie bewijs op dat is gebruikt bij de veroordeling van een of meer verdachten, in 4 zaken besloot het opsporingsteam op basis van de door de undercoveroperatie gegenereerde informatie dat de verdenking tegen een verdachte (gedeeltelijk) onterecht was (uitsluiting), in 1 zaak leverde de undercoveroperatie 'alleen' sturingsinformatie op; en in 22 zaken leverde de undercoveroperatie geen bijdrage aan het onderzoek of de berechting.

Behalve de bijdrage die undercoveroperaties leveren aan opsporing en berechting van verdachten, kunnen ook gerechtelijke uitspraken over de toelaatbaarheid van dit instrument worden gezien als 'resultaat'. Om te zien hoe rechtscolleges omgaan met verweren die door advocaten ten aanzien van undercoveroperaties naar voren worden gebracht, bestudeerden we meer dan 60 gerechtelijke uitspraken. In deze zaken bracht de verdediging van de verdachte bijvoorbeeld naar voren dat er sprake was geweest van ontoelaatbare uitlokking en/of dat de uitvoering van de operatie niet in overeenstemming was met de beginselen van proportionaliteit en/of subsidiariteit. Het overgrote deel van de verweren in de onderzochte uitspraken werd door de rechtscolleges verworpen. Voor de uitkomst van de beoordeling door een rechtscollege blijkt de transparantie van groot belang, dat wil zeggen de mate waarin het Openbaar Ministerie inzicht verschaft in de beslissing om tot inzet van een undercoveroperatie over te gaan alsmede in de daadwerkelijke uitvoering en in de uitkomsten van de operatie. In het overgrote deel van de zaken overtuigde de voorgelegde informatie het rechtscollege van de legitimiteit van de undercoveroperatie. In het relatief 
kleine aantal zaken waarin het rechtscollege een gevoerd verweer wel gegrond heeft verklaard, lag de reden daarvan vaak in een te geringe transparantie en controleerbaarheid van de undercoveroperatie.

Het meest opvallende kenmerk van de bestudeerde undercoveroperaties is de onvoorspelbaarheid van het verloop van de contacten tussen undercoveragent en subject, en dus van de undercoveroperatie als zodanig. Deze onvoorspelbaarheid komt het sterkst naar voren in operaties waarvan een of meer pseudo-kopen deel uitmaken. Tijdens een pseudo-koop doet een undercoveragent zich bijvoorbeeld voor als een medecrimineel die geïnteresseerd is in het kopen van wapens of drugs. In undercoveroperaties die zich richten op winstgemotiveerde criminaliteit zoals wapen- of drugshandel, doen undercoveragenten zich in feite voor als spelers op een criminele 'markt'. Criminele markten worden echter gekenmerkt door specifieke risico's (vergelijk Reuter, 1983: 113-117): het ongereguleerde karakter van de omgeving waarin spelers opereren; het feit dat het criminele 'bedrijfsproces' op ieder moment verstoord kan worden door arrestaties en inbeslagnames; en de 'collega's' van een speler - zijn medecriminelen - die onbetrouwbaar of incompetent kunnen blijken te zijn. Wanneer een undercoveragent zich op een criminele markt begeeft, wordt hij geconfronteerd met het onbetrouwbare en onvoorspelbare gedrag dat zo kenmerkend is voor die markt. De meeste van de pseudo-kopen in de door ons onderzochte zaken verliepen dan ook niet volgens plan. Ofwel een pseudo-koop ging helemaal niet door, bijvoorbeeld omdat het subject uiteindelijk niet kon leveren, ofwel een pseudo-koop ging wel door maar het subject bleek minder dan de afgesproken hoeveelheid te leveren. Onverwachtse ontwikkelingen zoals deze betekenen niet automatisch dat een undercoveroperatie (totaal) faalt, maar in het algemeen betekenen zij wel dat een operatie langer duurt of niet de gewenste resultaten oplevert. Vanwege de grote frequentie waarmee toezeggingen niet worden waargemaakt, handelskwalificaties niet blijken te kloppen of pseudo-kopen in andere opzichten niet aan de verwachtingen blijken te voldoen, is het in ieder geval niet eenvoudig om efficiënt zaken te doen met criminelen.

Deze bevinding contrasteert met een (impliciete) assumptie in het debat over undercoveroperaties. Een deel van het academische debat richt op het manipulatieve karakter van deze opsporingsmethode. Dit discours richt zich op de undercoveragent die het subject in een 'val' lokt en een actieve, sturende rol wordt toegeschreven in het contact met het subject, dat vooral een passieve, volgende rol lijkt te hebben. $\mathrm{Nu}$ is het zeker waar dat misleiding een essentieel kenmerk is van undercoveroperaties. Echter, het idee dat de undercoveragent degene is die het verloop van de contacten volledig domineert, gaat voorbij aan het feit dat, in veel zaken, het feitelijke verloop van een operatie in grote mate bepaald wordt door het onvoorspelbare gedrag van andere actoren. 


\section{Undercoveroperaties: infiltratie 2000-2005}

De undercoveroperaties uit 2004 die in de vorige subparagraaf zijn besproken, hebben zoals gezegd allen betrekking op de toepassing van het stelselmatig inwinnen van informatie en/ of pseudo-koop of -dienstverlening; geen van die zaken betrof infiltratie. Om inzicht te krijgen in de uitvoeringspraktijk van infiltratie, hetgeen de focus is van de tweede set onderzoeksvragen, is informatie verzameld over een langere periode, te weten de periode 2000-2005. De wettelijke voorwaarden voor de inzet van undercoverbevoegdheden verschillen per undercoverbevoegdheid. De voorwaarden die gelden voor infiltratie zijn zwaarder dan die voor pseudo-koop of -dienstverlening en de voorwaarden voor pseudokoop of -dienstverlening zijn weer zwaarder dan die voor het stelselmatig inwinnen van informatie. Infiltratie is dus de meeste 'zware' undercoverbevoegdheid in het Wetboek van Strafvordering en wordt hoofdzakelijk ingezet tegen criminaliteit in georganiseerd verband. Behalve de wettelijke vereisten zijn ook de autorisatieprocedures die gelden voor infiltratie zwaarder dan die voor de andere twee undercoverbevoegdheden. Eén van de onderzoeksvragen richt zich specifiek op hoe deze regulering uitpakt in de praktijk.

- Hoe vaak worden infiltratieoperaties ingezet?

- Welke resultaten hebben deze infiltratieoperaties opgeleverd?

- Hoe werkt de regulering van infiltratieoperaties uit in de uitvoeringspraktijk?

De data beslaan alle infiltratieoperaties in Nederland gedurende de periode 2000-2005. Een officier van justitie die een infiltratieoperatie in wil zetten moet (via de hoofdofficier van justitie) een voorstel daartoe indienen bij de Centrale toetsingscommissie (CTC). Als de CTC van oordeel is dat infiltratie geoorloofd is, wordt het voorstel doorgeleid naar het College van procureurs-generaal, dat de uiteindelijke beslissing neemt omtrent wel of geen goedkeuring. Voor alle Nederlandse opsporingsonderzoeken waarin gedurende de periode 2000-2005 een verzoek om toestemming voor infiltratie is ingediend bij de CTC (en waarin de infiltratieoperatie was afgerond op het moment dat ons onderzoek werd verricht), hebben we de CTC-dossiers en/of de eigenlijke opsporingsdossiers bestudeerd. ${ }^{170}$ De opsporingsdossiers bevatten de (relevante) gegevens omtrent alle ingezette politieactiviteiten, zoals verslagen van undercoveroperaties, verslagen van afgeluisterde telefoon- en face-to-face gesprekken, verslagen van observaties, verslagen van verhoren van verdachten en getuigen, en de resultaten van financiële onderzoeken en inbeslagnames. Verder namen we face-to-face interviews af bij 35 mensen, waarvan er 20 betrokken waren bij een of meer van de door ons bestudeerde infiltratieoperaties. De andere vijftien respondenten werden geselecteerd op grond van hun betrokkenheid bij andere zaken waarin infiltratie is ingezet.

170 Infiltratieoperaties in het kader van internationale rechtshulpverzoeken zijn niet meegenomen. 
In de periode 2000-2005 is in 23 Nederlandse opsporingsonderzoeken toestemming gevraagd voor de inzet van een infiltratieoperatie. ${ }^{171}$ In zestien gevallen gaf het College van procureurs-generaal toestemming voor het gebruik van dit middel. In veertien zaken is de infiltratieoperatie ook daadwerkelijk uitgevoerd. In zes van die veertien zaken heeft de infiltratieoperatie bewijs opgeleverd dat een rol heeft gespeeld bij de veroordeling van een of meer verdachten. Vier operaties genereerden 'alleen' sturings- en/of restinformatie. De overige infiltratieoperaties leverden geen bijdrage aan de opsporing of berechting van verdachten. ${ }^{172}$ In de vorige subparagraaf bespraken we het onvoorspelbare verloop van undercoveroperaties, vooral die operaties waarvan een of meer pseudo-kopen deel uitmaken. Het verloop van infiltratieoperaties blijkt minstens even onvoorspelbaar. Van de dertien infiltratieoperaties waarin de undercoveragent erin slaagde contact te maken met het subject, richtten er twaalf zich op het voortbrengen van een of meer pseudo-kopen. Geen enkele van die twaalf voorgenomen pseudo-kooptrajecten verliep volgens plan.

Behalve de infiltratieoperaties zelf bekeken we ook hoe de regulering van dit middel uitwerkt in de praktijk. Bij de beschrijving hiervan richten we ons op die aspecten van de regulering die niet altijd volledig blijken aan te sluiten op de uitvoeringspraktijk.

Zoals eerder aangegeven wordt in het Nederlandse Wetboek van Strafvordering onderscheid gemaakt tussen drie undercoverbevoegdheden: het stelselmatig inwinnen van informatie; de pseudo-koop of -dienstverlening; en infiltratie. Infiltratie wordt verondersteld riskanter te zijn dan de pseudo-koop of -dienstverlening en het stelselmatig inwinnen van informatie. De wettelijke voorschriften voor toepassing verschillen navenant: de voorwaarden voor infiltratie zijn zwaarder dan die voor pseudo-koop of -dienstverlening, terwijl de voorwaarden voor laatstgenoemde bevoegdheid weer zwaarder zijn dan die voor het stelselmatig inwinnen van informatie. In de uitvoeringspraktijk kan de toepassing van het stelselmatig inwinnen van informatie echter ingrijpender zijn dan de toepassing van infiltratie (Beijer et al., 2004: 103-104). De reden is dat in sommige gevallen van het stelselmatig inwinnen van informatie, bijvoorbeeld wanneer een undercoveragent wordt ingezet om te achterhalen of een man zijn vrouw heeft vermoord, de undercoveragent een vrij hechte band moet opbouwen met de verdachte; hij moet een zodanige persoonlijke

171 In feite is gedurende de periode 2000-2005 in 24 opsporingsonderzoeken toestemming gevraagd voor infiltratie. Eén van deze opsporingsonderzoeken is echter niet meegenomen omdat de infiltratieoperatie nog lopende was op het moment dat onze dataverzameling plaatsvond.

172 Het is niet zinvol om de resultaten van infiltratieoperaties (in kwantitatieve termen) te vergelijken met de resultaten van het stelselmatig inwinnen van informatie en pseudo-koop of -dienstverlening. Ten eerste is het onderscheid tussen de drie in het Wetboek van Strafvordering onderscheiden undercoverbevoegdheden, in de uitvoeringspraktijk niet altijd even scherp. Ten tweede zijn verschillende infiltratieoperaties voorafgegaan door de inzet van het stelselmatig inwinnen van informatie en de meeste infiltratieoperaties gingen gepaard met het gebruik van pseudo-koop. Ten derde worden het stelselmatig inwinnen van informatie en pseudo-koop of -dienstverlening ook ingezet in opsporingsonderzoeken die zich richten op één enkele verdachte, terwijl infiltratie altijd wordt ingezet in het kader van een criminele groepering, wat de kans groter maakt dat de operatie bewijs of andere relevante informatie oplevert ten aanzien van tenminste één verdachte. 
band met de verdachte opbouwen dat deze zich vrij voelt om open en eerlijk te zijn. Het opbouwen van een dergelijke vertrouwensband en het vervolgens verraden van deze 'vriendschap', kan psychologisch veel belastender zijn voor de undercoveragent en het subject dan wanneer de undercoveragent een drugshandelaar (of wapenhandelaar) speelt, zoals in verschillende infiltratieoperaties het geval is.

Verder kunnen gecentraliseerde autorisatieprocedures leiden tot een terughoudendheid onder officieren van justitie ten opzichte van undercoveroperaties, met name infiltratie. Een officier van justitie die infiltratie in wil zetten moet voldoen aan verschillende autorisatievereisten. Uiteindelijk moet de goedkeuring worden verkregen van het hoogste niveau binnen het Openbaar Ministerie, het College van procureurs-generaal, een goedkeuring die, wanneer zij wordt verleend, bovendien periodiek moet worden verlengd. Als gevolg van deze procedure kan bij officieren van justitie de vrees ontstaan dat zij, wanneer zij voor dit middel kiezen, de controle over het opsporingsonderzoek verliezen. Vanwege die vrees zouden zij de inzet van infiltratie kunnen vermijden of kiezen voor een combinatie van het stelselmatig inwinnen van informatie en pseudo-koop, in welk geval geen tostemming van het College van procureurs-generaal is vereist (zie ook Beijer et al., 2004: 109).

Ten slotte blijkt het prospectieve element van de toets op subsidiariteit in zekere zin te botsen met de fundamentele onvoorspelbaarheid die kenmerkend is voor opsporingsonderzoeken naar georganiseerde criminaliteit. Wanneer een voorgestelde infiltratieoperatie wordt getoetst op subsidiariteit, moet het College van procureurs-generaal beoordelen of het doel van het opsporingsonderzoek niet met andere middelen kan worden bereikt. Deze toetst op subsidiariteit heeft zowel een retrospectief als een prospectief element. Het retrospectieve element betreft de opsporingsinstrumenten die al zijn ingezet op het moment dat het voorstel voor de toepassing van infiltratie wordt ingediend. Het prospectieve element behelst de inschatting dat andere opsporingsinstrumenten dan infiltratie in de komende weken en maanden tot doorslaggevende resultaten zouden kunnen leiden. Het verloop van opsporingsonderzoeken naar georganiseerde criminaliteit is echter erg onvoorspelbaar. Factoren die aan die onvoorspelbaarheid ten grondslag liggen, zijn het grillige gedrag van criminelen, het relatief grote aantal verdachten dat in het vizier komt tijdens opsporingsonderzoeken naar georganiseerde criminaliteit en het feit dat vaak verschillende opsporingsinstrumenten tegelijkertijd worden ingezet. In verschillende zaken waarin het College van procureurs-generaal toestemming had gegeven voor de inzet van infiltratie bleken, nadat de toestemming was gegeven, andere opsporingsinstrumenten toch beslissende resultaten te genereren, ook al werden zij als ineffectief beoordeeld. 


\section{S.1.2 De financiële aanpak}

De derde en de vierde set onderzoeksvragen concentreren zich op de financiële aanpak van georganiseerde criminaliteit. Deze financiële aanpak bestaat uit twee hoofdelementen. Enerzijds gaat het om anti-witwasmaatregelen, die zich vooral richten op het strafbaar stellen van handelingen met uit misdaad afkomstig geld en het tegengaan van het gebruik door criminelen van de legale financiële en economische infrastructuur. Anderzijds gaat het om maatregelen gericht op het afpakken van de criminele verdiensten van daders (Gallant, 2005: 11).

\section{Investeringen van daders in de legale economie}

De derde set onderzoeksvragen richt zich op wat daders eigenlijk doen met hun geld. Het belangrijkste punt van aandacht betreft de investeringen van daders in de legale economie, aangezien dergelijke investeringen een belangrijke reden voor zorg zijn onder beleidsmakers (zie ook Kruisbergen et al., 2015b).

- Waar investeren daders hun geld in?

- In welke landen doen zij die investeringen?

- Wat kan uit de investeringen van daders worden afgeleid over onderliggende strategieën en motieven?

De data die wij voor de beantwoording van deze vragen gebruiken bestaan uit zaaksverslagen van de Monitor Georganiseerde Criminaliteit. De Monitor Georganiseerde Criminaliteit is een doorlopend onderzoeksproject naar de aard van de georganiseerde criminaliteit in Nederland. In vier rondes van dataverzameling, die de periode 19962011 beslaan, zijn 150 zaken geanalyseerd. Voor deze 150 zaken, die een brede variatie van vormen van georganiseerde criminaliteit omvatten, is aan de hand van een itemlijst het opsporingsdossier uitgebreid bestudeerd. Dit heeft geresulteerd in 150 zogenoemde zaaksverslagen. Om de derde set van onderzoeksvragen te beantwoorden, zijn alle 150 zaaksverslagen doorzocht op aanwezige informatie over het vermogen van verdachten. In 124 van de 150 zaken werd informatie gevonden over investeringen in onroerend goed en/ of bedrijven in Nederland of een ander land. In totaal ging het in die 124 zaken om 1.196 individuele bezittingen.

De investeringen van daders in onder andere drugs-, mensensmokkel-, mensenhandel en wapenhandelzaken, bestaan voor een groot deel uit woningen. Deze woningen variëren van bescheiden onderkomens tot zeer luxueuze villa's, die worden gebruikt door de daders zelf of hun naasten of worden verhuurd. De bedrijven waar deze daders in investeren betreffen vooral bedrijven in de groot- en detailhandel (bedrijven die fruit importeren bijvoorbeeld), horecabedrijven, transport bedrijven, bordelen, en bedrijven die behoren tot de financiële dienstverlening. Bij laatstgenoemde gaat het niet om banken, maar om management-/ 
investeringsbedrijven of holdings die bijvoorbeeld worden gebruikt om ander bezit, zoals onroerend goed, onder te brengen. Een deel van de zaken uit de categorie fraude en witwassen laten een ander patroon zien. In de 'onroerendgoedportfolio' van deze daders zien we meer zakelijk onroerend goed. Onder de bedrijven waarin deze daders investeren zien we meer vastgoedbedrijven en de zojuist genoemde holdings. In het algemeen (over categorieën van misdrijven heen) zijn investeringen in de sectoren landbouw, mijnbouw, industrie en energie afwezig of sterk ondervertegenwoordigd. Verder bevatten de zaaksdossiers voor meer dan de helft van de bedrijven waarin daders hebben geïnvesteerd indicaties dat het bedrijf wordt gebruikt voor criminele activiteiten. De criminele doeleinden waarvoor de bedrijven worden gebruikt liggen op het vlak van witwassen, logistiek of legitimering.

Voor bedrijven waar daders in investeren geldt dat in de meeste gevallen de dader op enigerlei wijze persoonlijk betrokken is bij het bedrijf, dat wil zeggen dat het bedrijf (gedeeltelijk) onder controle staat van de dader en voor criminele doeleinden wordt gebruikt en/of dat er daadwerkelijk legale economische activiteiten plaatsvinden ten gunste van de dader. Puur financiële investeringen daarentegen, dat wil zeggen obligaties, opties en aandelen in bedrijven waarbij daders nít persoonlijk betrokken zijn, zoals beursgenoteerde bedrijven, werden maar in een klein aantal zaken aangetroffen.

Wat betreft het land waarin de investeringen worden gedaan, geldt dat daders overwegend investeren in het 'thuisland' ( $82 \%$ van de individuele bezittingen). Dit 'thuisland' is ofwel het land van herkomst, dat wil zeggen Nederland voor autochtone daders, Turkije voor daders van Turkse afkomst etc., ofwel het woonland, dat wil zeggen Nederland voor in Nederland woonachtige daders van bijvoorbeeld Turkse afkomst. Kijken we naar specifieke landen waarin is geïnvesteerd, dan zien we dat $64 \%$ van alle bezittingen zich in Nederland bevindt, terwijl 36\% zich bevindt in een ander land.

De analyses van de investeringen van daders waren vooral verkennend van aard. Toch kunnen zij ons iets leren over de houdbaarheid van verschillende theoretische benaderingen die in de literatuur over witwassen en georganiseerde criminaliteit zijn te vinden. Eén zo'n benadering is de economische (of economistische) benadering. Deze benadering gaat ervan uit dat daders bij investeringsbeslissingen vooral kosten- en batenafwegingen maken en daarbij een mondiaal perspectief hebben, dat wil zeggen dat ze investeren in een sterk geglobaliseerde economie. De belangrijkste factor voor het kiezen van een investering is hierbij winstgevendheid en daders worden verondersteld erg flexibel te zijn wat betreft het van land van investering, al naar gelang de uitkomst van de kosten- en batenafweging. De geografische horizon van de investeringsportfolio's van onderzochte daders blijkt echter vrij beperkt, aangezien de meeste investeringen worden gedaan in het 'thuisland'. Bovendien investeren daders, vooral in (onder andere) drugs-, mensensmokkel-, mensenhandel- en wapenhandelzaken, onder andere in woningen en ander onroerend goed, hetgeen de mogelijkheid beperkt om snel investeringen te verplaatsen. Ook investeren ze in bedrijven waarmee ze (waarschijnlijk) bekend zijn vanuit het dagelijks leven (groot-/ 
detailhandel, horeca) en die vaak worden gebruikt voor criminele activiteiten. Puur financiële investeringen daarentegen werden veel minder vaak aangetroffen. Deze uitkomsten wijzen uit dat de economische benadering waarschijnlijk niet het meest adequate perspectief biedt om de investeringsbeslissingen van daders te begrijpen.

De criminele-infiltratiebenadering past ook niet goed bij onze empirische resultaten. Deze benadering benadrukt dat investeringen in de legale economie macht (invloed) voor daders met zich meebrengen. Er werden echter geen voorbeelden gevonden van daders die dankzij hun investeringen vanuit de 'onderwereld' opklommen naar machtige posities op nationaal niveau in de Nederlandse 'bovenwereld'. Wel vonden we een klein aantal daders met sterke gevestigde posities in de reguliere samenleving, maar (sommige van) deze gevallen zijn eerder een illustratie van 'infiltratie' in omgekeerde richting; 'legitieme' zakenmensen en professionals zonder antecedenten die hun positie in de legale economie misbruiken om criminele activiteiten te ontplooien.

In plaats van winstgevendheid (economische benadering) of macht (crimineleinfiltratiebenadering), lijkt nabijheid een meer geschikte term om de investeringen in de bestudeerde zaken te beschrijven. De resultaten laten immers zien dat de afstand tussen de dader en zijn investeringen vaak klein is, zowel in fysieke als in sociale zin. Deze 'nabijheid' past goed binnen een benadering van georganiseerde criminaliteit die de nadruk legt op de sociale gelegenheidsstructuur. Kleemans en De Poot (2008) gebruikten de term 'sociale gelegenheidsstructuur' om de betrokkenheid bij georganiseerde criminaliteit te verklaren: criminele mogelijkheden hangen af van het sociale netwerk van personen, dat op zijn beurt weer afhangt van iemands leeftijd, sociale en geografische/etnische herkomst, beroep etc. Deze sociale gelegenheidsstructuur blijkt ook van nut wanneer we het investeringsgedrag van daders willen duiden: de mogelijkheden om te investeren worden bepaald, én beperkt, door iemands directe sociale omgeving.

\section{Het opsporen en ontnemen van uit misdaad afkomstig vermogen}

De vierde set onderzoeksvragen richt zich op pogingen van de autoriteiten om criminele verdiensten af te pakken. We concentreren ons op één specifiek instrument dat daartoe wordt gebruikt: de ontnemingsmaatregel. De empirische data bestaan uit zaken van de Monitor Georganiseerde Criminaliteit, vonnissen van ontnemingszaken, en gegevens van het Centraal Justitieel Incassobureau (CJIB), dat verantwoordelijk is voor de uitvoering van ontnemingsmaatregelen. Tezamen geven deze bronnen onder andere een compleet beeld van de rechtsgang - van de eis van de officier van justitie in eerste aanleg tot en met een eventuele uitspraak van de Hoge Raad - alsook de incasso van de ontnemingsmaatregel bij 102 veroordeelde daders. Daarmee geven deze bronnen tevens inzicht in het probleem van uitval bij de ontneming, dat wil zeggen het grote verschil tussen de geschatte criminele winsten enerzijds en de daadwerkelijk ontnomen bedragen anderzijds. Twee onderzoeksvragen worden beantwoord: 
- Hoe werkt het opsporen en ontnemen van criminele verdiensten uit in zaken die zich afspelen in de georganiseerde criminaliteit?

- Welke verklaringen zijn er voor het fenomeen van uitval in ontnemingszaken?

Voor de 102 veroordeelden waarvoor we een compleet konden geven van zowel de gehele rechtsgang als de incasso van de ontnemingsmaatregel, bedraagt het totale bedrag aan ontnemingsvorderingen dat door de officieren van justitie in eerste aanleg is geëist $€ 61.928 .210$. Aan het eind van de rechtsgang, wanneer de rechtbank en eventueel ook het gerechtshof en de Hoge Raad zich over de zaak hebben gebogen, is dit gereduceerd tot $€ 27.463 .899$ (44 procent), waarvan juli $2015 € 11.325 .036$ (41 procent van $€ 27.463 .899 ; 18$ procent van $€ 61.928 .210$ ) is betaald (in 26 zaken is de incasso nog gaande).

De uitval is dus aanzienlijk, zowel gedurende de rechtsgang als tijdens de executie van de ontnemingsmaatregel. Een belangrijke factor daarbij is hoe het 'wederrechtelijk verkregen voordeel' (criminele verdiensten) wordt vastgesteld in de rechtspraktijk. Er bestaat geen eenduidige, bindende omschrijving van 'wederrechtelijk verkregen voordeel' of van hoe dat voordeel moet worden vastgesteld. Bovendien is de beschikbare hoeveelheid betrouwbare informatie om criminele verdiensten vast te stellen per definitie beperkt. Door deze 'fundamentele onbepaaldheid' bestaat er een brede variatie aan mogelijke zienswijzen op criminele verdiensten. Dit komt duidelijk naar voren in de bestudeerde zaken. In de meeste van de onderzochte zaken nam het rechtscollege de vaststelling van de criminele verdiensten door het Openbaar Ministerie niet over en werd besloten dat een (veel) lager bedrag van toepassing was. Hoe criminele verdiensten worden bepaald in het recht en de praktijk speelt waarschijnlijk ook een belangrijke rol bij de uitval die plaatsvindt gedurende de incasso van ontnemingsmaatregelen. Het uitgavenpatroon van een veroordeelde en verliezen gedurende criminele transacties worden (gedeeltelijk) niet meegenomen wanneer het te ontnemen bedrag wordt vastgesteld. Dit is mogelijk goed te verdedigen op juridische en ideologische gronden, maar het brengt ook het risico met zich mee dat veroordeelden een ontnemingsmaatregel niet volledig kunnen voldoen.

Een andere oorzaak van de uitval betreft een probleem waar de financiële aanpak van georganiseerde criminaliteit in het algemeen onder gebukt gaat: het feit dat (verstandige) daders hun vermogen verbergen, voor een deel in het buitenland, en de autoriteiten er niet in slagen dat vermogen volledig op te sporen. Verder is een deel van de uitval het gevolg van het feit dat rechtscolleges in sommige zaken een korting toepassen omdat de duur van de rechtsgang naar hun oordeel de redelijke termijn heeft overschreden. Ten slotte was in een aantal zaken de draagkracht van de veroordeelde voor het rechtscollege een reden om een lager bedrag op te leggen of waren er juridische gronden om de incasso van de ontnemingsmaatregel voortijdig te staken. 


\section{S.2 Bereik van het onderzoek en methodologische overwegingen}

Dit proefschrift richt zich op de bestrijding van georganiseerde criminaliteit. $\mathrm{Nu}$ is het zo dat criminaliteit zich doorgaans in het verborgene afspeelt. Hetzelfde geldt overigens in zekere zin voor de bestrijding ervan. Dit kenmerk van het onderzoeksveld brengt beperkingen met zich mee voor een onderzoeker. De methoden die een onderzoeker kiest en de databronnen die worden gebruikt kennen altijd beperkingen, en dit geldt des te meer voor onderzoek naar een verborgen fenomeen als georganiseerde criminaliteit. Wat zijn de specifieke beperkingen, en de sterke punten, van onze onderzoeksopzet?

\section{S.2.1 Bereik en beperkingen}

\section{Undercoveroperaties}

Ons onderzoek is een van de zeer weinige studies die empirisch inzicht bieden in de uitvoeringspraktijk en de resultaten van deze undercoveroperaties. Bovendien vond er een vrij uitgebreide dataverzameling plaats. We verzamelden informatie over alle 89 undercoveroperaties die in één jaar, 2004, werden overwogen. ${ }^{173}$ Voor infiltratie, dat (nog) minder vaak wordt ingezet dan het stelselmatig inwinnen van informatie en pseudo-koop, verzamelden we informatie over alle 23 opsporingsonderzoeken waarin gedurende de periode 2000-2005 een voorstel was ingediend voor infiltratie bij de Centrale toetsingscommissie (CTC). ${ }^{174}$ Voor de twee deelonderzoeken naar undercoveroperaties zijn de volgende bronnen gebruikt: CTC-dossiers, opsporingsdossiers, informatie van de infiltratieteams, interviews en jurisprudentie.

Het onderzoeksontwerp heeft echter ook zijn beperkingen. Zo hebben we bijvoorbeeld geen undercoveragenten geïnterviewd. Zij zijn vooral vanwege veiligheidsoverwegingen buiten het onderzoek gehouden. Bij de inzet van een undercoveroperatie is de veiligheid van undercoveragenten een topprioriteit voor het Openbaar Ministerie en de politie. De kring van personen bij wie de identiteit van een undercoveragent bekend is, wordt

173 We verzamelden informatie van de vijf operationele politiële infiltratieteams omtrent alle 37 opsporingsonderzoeken ten behoeve waarvan in 2004 contact is opgenomen met een infiltratieteam en waarin is besloten om een undercoveroperatie in te zetten. Vier van de vijf politiële infiltratieteams konden ook informatie aanleveren met betrekking tot 46 opsporingsonderzoeken waarin het raadplegen van het infiltratieteam uitmondde in de beslissing om géén undercoveroperatie in te zetten. Aangenomen dat de verhouding tussen positieve en negatieve beslissingen (wel/geen inzet undercoveroperatie) zoals die bij deze vier infiltratieteams ligt ook geldt voor het vijfde infiltratieteam, komt het totale aantal negatieve beslissingen op 52, wat het totale aantal opsporingsonderzoeken waarin de inzet van een undercoveroperatie is overwogen op $(37+52=) 89$ brengt (zie hoofdstuk 1).

174 In feite is gedurende de periode 2000-2005 in 24 opsporingsonderzoeken toestemming gevraagd voor infiltratie. Eén van deze opsporingsonderzoeken is echter niet meegenomen omdat de infiltratieoperatie nog lopende was op het moment dat onze dataverzameling plaatsvond. 
zo klein als mogelijk gehouden. We hebben overigens wel de leidinggevenden van de undercoveragenten, de teamleiders van de infiltratieteams, geïnterviewd. ${ }^{175}$

Een andere beperking betreft het feit dat de zaken die we hebben bestudeerd betrekking hebben op 2004 dan wel de periode 2000-2005. Is de uitvoeringspraktijk sindsdien veranderd en zijn die veranderingen zodanig dat zij de validiteit van de uitkomsten aantasten? Institutionele veranderingen hebben er in ieder geval wel plaatsgevonden. Of door die institutionele veranderingen de uitvoeringspraktijk is gewijzigd kan niet worden gezegd, omdat er geen recent onderzoek is waarmee we onze uitkomsten kunnen vergelijken. Hieronder gaan we in op deze institutionele (en andere) veranderingen.

In 2005 waren er vijf actieve gespecialiseerde politiële infiltratieteams; één landelijk en vier regionale teams. Als gevolg van een reorganisatie die plaatsvond in 2008 zijn deze teams samengevoegd in één centraal aangestuurd landelijk team: de Unit Werken Onder Dekmantel (WOD). Deze nieuwe unit moest onder andere een grotere diversiteit tot stand brengen, zowel wat betreft de expertise en achtergrond van undercoveragenten als de soort zaken waarin het middel wordt ingezet. De unit WOD bestaat uit gespecialiseerde politieambtenaren. In 2009 verscheen er een richtlijn van de politie die toeziet op de inzet van reguliere politieambtenaren (niet werkzaam bij de unit WOD), bij kleine, 'eenvoudige' pseudo-kopen, zoals bij de aankoop van een goed dat via internet te koop wordt aangeboden. Deze politieambtenaren hebben weliswaar een specifieke opleiding gevolgd, maar deze is veel minder intensief dan die is vereist voor leden van de unit WOD. Of en zo ja welke effecten de creatie van de unit WOD en de daarmee samenhangende veranderingen hebben gehad op de uitvoeringspraktijk, is op dit moment niet duidelijk. Het is echter mogelijk dat het heeft geleid tot een toename van het gebruik van undercoveroperaties. In de maand waarin het laatste hoofdstuk van dit proefschrift werd afgerond, mei 2016, publiceerde het Algemeen Dagblad informatie waaruit zou blijken dat het aantal undercoveroperaties inderdaad is toegenomen. In 2011, 2012 en 2013 heeft de unit WOD, aldus de gepubliceerde informatie, operaties uitgevoerd in respectievelijk 55, 82 en 68 opsporingsonderzoeken (Voskuil, 2016). De krant verkreeg deze informatie via een beroep op de Wet openbaarheid van bestuur (WOB). Ook andere factoren kunnen hebben bijgedragen aan een toename van het aantal undercoveroperaties. Zo kan de terughoudendheid onder politieambtenaren en officieren van justitie ten opzichte van de inzet van undercoveroperaties bijvoorbeeld zijn afgenomen, omdat de afstand tot de IRT-affaire zowel chronologisch als mentaal is gegroeid. ${ }^{176}$ Verder is sinds het meest recente jaar waarop onze data betrekking heeft (2005) het belang van internet waarschijnlijk toegenomen, zowel voor daders als voor de opsporing.

175 Een aantal studies richt zich specifiek op de effecten op undercoveragenten zelf van het onder dekmantel opereren, zoals Girodo, 1991; Girodo et al., 2002; Macleod, 1995; Miller, 2006.

176 Het veranderde beleid ten aanzien van de criminele burgerinfiltrant (zie hoofdstuk 1) zou kunnen worden gezien als een illustratie van een afnemende terughoudendheid ten opzichte van opsporingsmethoden die ten tijde van de IRT-affaire en haar nasleep erg werden bekritiseerd. 
Ook dit kan hebben bijgedragen aan een toename van het aantal undercoveroperaties, bijvoorbeeld omdat online undercoveroperaties minder arbeidsintensief zouden zijn dan offline operaties.

Een laatste opmerking omtrent het bereik van onze studie naar undercoveroperaties betreft de interpretatie van onze onderzoeksuitkomsten. Ons onderzoek richtte zich op de resultaten die de politie behaalde met de inzet van undercoveroperaties. We beschreven de bijdragen van deze operaties aan opsporingsonderzoek en berechting. Iemand zou zich af kunnen vragen hoe deze resultaten beoordeeld moeten worden: hoe goed of slecht zijn deze resultaten? Een dergelijke vraag kan (op dit moment) niet worden beantwoord. Ten eerste kunnen we de door ons in kaart gebrachte resultaten niet of nauwelijks in vergelijkend perspectief plaatsen omdat onderzoek naar opsporingsmethoden schaars is. Ten tweede is het vergelijken van resultaten van verschillende opsporingsmiddelen toch al lastig, aangezien de opsporingspraktijk in het algemeen sterk afwijkt van een (klassiek) experimentele setting waarin de invloed van één specifieke factor kan worden onderscheiden van de invloed van andere factoren. Dit geldt des te meer voor opsporingsonderzoeken naar georganiseerde criminaliteit. In onderzoeken naar georganiseerde criminaliteit worden opsporingsmiddelen zoals undercoveroperaties, het gebruik van informanten of het afluisteren van telefoon- en/of face-to-face gesprekken, vaak in combinatie met andere middelen gebruikt. Informatie gegenereerd door een opsporingsmiddel wordt daarbij vaak aangewend voor (een meer effectieve) inzet van een ander middel. Ook verschillen de voorwaarden waaronder opsporingsmiddelen worden ingezet en zijn deze lastig te sturen, zoals (interpretatie van) de geldende regulering en de redenen en doelen van inzet.

\section{Investeringen van daders in de legale economie}

Net als empirisch onderzoek naar de toepassing van opsporingsmethoden, is ook onderzoek naar investeringen van daders in de legale economie schaars. Onze studie geeft inzicht in de bezittingen van daders op basis van 150 zaken uit de Monitor Georganiseerde Criminaliteit. Onze resultaten wezen vooral op het belang van de sociale gelegenheidsstructuur wanneer we investeringspatronen willen begrijpen. We concludeerden dat 'nabijheid' een meer geschikte term is om de investeringsbeslissingen van daders te beschrijven dan 'winstgevendheid' of 'macht'. We pretenderen echter niet dat onze resultaten een volledig eenduidig of definitief antwoord bieden op vragen omtrent investeringen van daders. Ook dit deelonderzoek heeft zijn beperkingen.

Het deelonderzoek is vooral gebaseerd op informatie uit opsporingsdossiers. Dat betekent in ons geval dat de studie alleen betrekking heeft op zaken die aandacht kregen van de politie en waarin verdachten werden aangehouden en dat alleen die investeringen in beeld zijn gekomen waarover de politie enige informatie kon verzamelen. Het gebruik van opsporingsdossiers brengt het risico met zich mee dat bepaalde resultaten verborgen blijven, 
niet omdat de feiten er niet zijn maar simpelweg omdat de politie ze niet kon vinden. ${ }^{177}$ Een mogelijk gevolg hiervan kan zijn dat het belang van bepaalde vermogensbestandsdelen of witwasmethoden worden onderschat, zoals investeringen in het buitenland. Verder richtten we ons op het feitelijk bezit van bijvoorbeeld onroerend goed en niet op het formele eigendom. Bovendien hebben we het aanhouden van contant geld en spaartegoeden niet meegenomen in onze analyses (zie hoofdstuk 4). Wanneer formeel eigendom, contant geld en spaartegoeden wel meegenomen zouden worden, zou dit tot andere uitkomsten kunnen leiden. Ten slotte is het zo dat onze data betrekking hebben op georganiseerde criminaliteit in Nederland, die in belangrijke mate bestaat uit transit crime, dat wil zeggen internationale illegale handel. Onderzoek naar investeringen van daders die participeren in andere types van georganiseerde criminaliteit, zoals het via afpersing en protectie gedeeltelijk overnemen van bedrijfstakken of regio's (racketeering), kan tot deels andere uitkomsten leiden, zoals naar voren komt uit analyses van investeringen van de Italiaanse maffia (zie bijvoorbeeld Riccardi, 2014). ${ }^{178}$

\section{Het opsporen en ontnemen van uit misdaad afkomstig vermogen}

Voor het onderzoek naar het opsporen en ontnemen van uit misdaad afkomstig vermogen gebruikten we drie databronnen, te weten zaken uit de Monitor Georganiseerde Criminaliteit, data van het Centraal Justitieel Incassobureau (CJIB) en vonnissen van ontnemingszaken. Door de combinatie van deze databronnen draagt de studie bij aan het inzicht in de praktijk en resultaten van de financiële aanpak van georganiseerde criminaliteit. Voor 102 daders analyseerden we zowel de rechtsgang als de incasso van de ontnemingsmaatregel. Voor die 102 daders gaven we een compleet beeld: van de eis van officier van justitie in de ontnemingszaak in eerste aanleg, de uitspraak van de rechtbank in eerste aanleg, het hoger beroep, cassatie bij de Hoge Raad tot en met wat de daders uiteindelijk daadwerkelijk betaalden. Omdat we ook de ontnemingsvonnissen hebben bestudeerd, waarmee we inzicht verkregen in de gronden waarop rechtscolleges beslisten om al dan niet af te wijken van de eis van de officier van justitie (of van de uitspraak van een lager rechtscollege), konden we bovendien een kwalitatieve duiding geven aan de gepresenteerde cijfers. De meeste van het relatieve kleine aantal andere empirische onderzoeken op dit terrein geven geen compleet beeld van de ontnemingsketen voor de bestudeerde gevallen en/of ontberen een kwalitatieve

177 Beargumenteerd kan worden dat opsporingsdossiers per definitie geen informatie bevatten over investeringen die via succesvolle witwasmethoden zijn aangeschaft. Deze beperking wordt enigszins gecompenseerd door het feit dat we bij het bestuderen van de zaaksdossiers alle beschikbare informatie over het vermogen van daders hebben gebruikt; niet alleen informatie over in beslag genomen goederen maar ook informatie afkomstig van bijvoorbeeld informanten of afgeluisterde gesprekken (zie hoofdstuk 1).

178 Riccardi analyseerde geconfisceerde bedrijven in Italië. Hij concluderde dat de samenstelling van de investeringsportfolio van personen binnen de maffia wordt bepaald door onder andere de mogelijkheid om via de investeringen territoriale controle uit te oefenen en/of politieke en sociale relaties uit te bouwen (Riccardi, 2014; Savona, 2015; zie also Kleemans, 2015). 
duiding. We weten niet in welke mate de 102 ontnemingszaken representatief zijn voor alle ontnemingsprocedures die worden gevoerd tegen daders in de georganiseerde criminaliteit. De uitkomsten van de analyses van deze steekproef komen echter op hoofdlijnen overeen met wat bekend is uit andere bronnen: een scheve verdeling wat betreft de hoogte van de ontnemingsmaatregelen (veel 'kleine' en weinig 'grote' ontnemingen) (Van Duyne et al., 2014); grote uitval gedurende de rechtsgang (Openbaar Ministerie en Politie, 2015: 1314); en grote uitval bij de incasso van de ontnemingsmaatregelen (Minister van Veiligheid en Justitie, 2015: 3; data van het CJIB, niet gepubliceerd; Van Duyne et al., 2014; voor Engeland en Wales, zie Bullock et al., 2009).

Onze resultaten hebben alleen betrekking op ontnemingsmaatregelen. De ontnemingsmaatregel heeft als instrument om uit misdaad afkomstige verdiensten af te pakken de meeste aandacht gekregen in het Nederlandse debat op dit terrein. Er zijn echter andere instrumenten, zoals inbeslagnames en verbeurdverklaringen, en schikkingen (en transacties). In de laatste jaren is het totale bedrag aan 'afgepakt' geld sterk toegenomen, wat voor een belangrijk deel het resultaat is van een schikkingen. In paragraaf S.3.3. gaan we hier verder op in. Verder is het wettelijk kader voor het ontnemen van uit misdaad afkomstig geld verschillende keren gewijzigd (zie hoofdstuk 5) en is het beschikbare budget voor 'afpakken' verhoogd. Of, en zo ja in welke mate, deze veranderingen van invloed (zullen) zijn op de resultaten, is nog onbekend.

\section{S.2.2 Toegevoegde waarde van de onderzoeksopzet}

\section{Zicht op de complexiteit van opsporingsonderzoeken}

In deze studie beoogden we, onder andere, om een zowel breed als diep inzicht te bieden in het gebruik van undercoveroperaties in opsporingsonderzoeken. We verzamelden informatie over concrete zaken waarin dit middel is ingezet, gebruikten een open, kwalitatieve benadering en combineerden verschillende databronnen: opsporingsdossiers (en CTC-dossiers), informatie van infiltratieteams, interviews en jurisprudentie. Dit stelde ons in staat om niet alleen informatie te verschaffen over de aard van en het aantal undercoveroperaties in Nederland, maar om tevens inzicht te bieden in hoe dit middel bijdraagt aan opsporing en berechting van daders, hoe de interactie tussen undercoveragent en subject verloopt, en hoe regulering uitwerkt in de praktijk.

De opsporing van georganiseerde criminaliteit is niet een populair onderzoeksterrein onder criminologen (De Poot, 2010: 102; Grabosky, 2010: 364). Dit betekent niet dat onderzoek naar het handelen van de politie volledig ontbreekt. Er is, bijvoorbeeld in de Verenigde Staten en het Verenigd Koninkrijk, een groeiend aantal evaluaties van politieactiviteiten. Deze studies vormen de basis voor evidence-based policing, waarbij politieactiviteiten worden gestuurd op grond van 'bewijs' met betrekking tot 'wat werkt' (what works): met welke praktijken en strategieën worden de doelen van politieoptreden 
het meest kosteneffectief bereikt. Studies die vanuit dit kader opereren richten zich vaak op het kwantitatief meten van de processen en effecten van het politiewerk, bij voorkeur door middel van gerandomiseerd onderzoek met een controlegroep. Effecten worden daarbij gemeten door gebruik te maken van indicatoren als slachtofferschap, geregistreerde misdrijven, recidive en aantallen arrestaties en veroordelingen. Vanuit het evidence-based policing-perspectief is een groot aantal studies voortgekomen op een breed scala aan onderwerpen, zoals politieoptreden bij huiselijk geweld, de effecten van het vervolgen van jeugdige daders op recidivisme en buurtpreventieprogramma's (Sherman, 2013). Bovendien heeft het bijgedragen aan de erkenning dat onderzoek belangrijk is en dat geprobeerd moet worden om een empirisch fundament te creëren voor het gebruik van politiemiddelen.

Echter, niet alle relevante kenmerken van opsporingsonderzoeken, noch alle resultaten van opsporingsmethoden, kunnen gevangen worden in een volledig voorgestructureerd onderzoeksontwerp. Bij sommige onderwerpen laat de complexiteit of het gebrek aan eerder onderzoek een dergelijke benadering niet toe. Om inzicht te verkrijgen in de uitvoeringspraktijk en resultaten van undercoveroperaties, bijvoorbeeld, was het nodig om zaken waarin dit middels is ingezet vrij uitvoerig te bestuderen. Alleen dan ontstaat er een beeld van de context waarin de inzet plaatsvindt, wat betreft de soort daders en criminele activiteiten waar die inzet zich op richt, de interactie tussen undercoveragent en het subject, andere opsporingsinstrumenten die zijn ingezet, gemaakte keuzes tijdens de undercoveroperaties en de uitkomst van de zaak. Door onze onderzoeksopzet waren we in staat om de resultaten van een undercoveroperatie te interpreteren in relatie tot de specifieke kenmerken van het opsporingsonderzoek waarin de operatie is ingezet (De Poot, 2010: 102-104). In de bestaande literatuur over undercoveroperaties worden de resultaten van dit middel vooral besproken in termen van arrestaties, inbeslagnames en veroordelingen. Zoals in ons onderzoek is geïllustreerd, kunnen undercoveroperaties echter ook op andere manieren bijdragen aan de opsporing. Ze kunnen het inzicht genereren dat een verdenking waarschijnlijk (gedeeltelijk) onterecht is, op basis waarvan een persoon uitgesloten kan worden van verder onderzoek. Behalve veroordelingen en uitsluiting kan een undercoveroperatie ook sturingsinformatie voortbrengen. Dergelijke informatie kan bijvoorbeeld worden gebruikt ten behoeve van de (meer effectieve) inzet van een ander middel, zoals wanneer een undercoveragent informatie verzamelt over de door daders gebruikte communicatiemiddelen of smokkelmethoden.

Het belang van het doen van onderzoek naar het gebruik van opsporingsmethoden is bovendien veel breder dan het in kaart brengen van de resultaten die deze methoden voortbrengen. Opsporingsmethoden, en maatregelen tegen georganiseerde criminaliteit in het algemeen, gaan vaak gepaard met een inbreuk op fundamentele rechten van de mens en zijn regelmatig onderwerp van debat. Om te voorkomen dat deze debatten vooral worden gevoerd op grond van ongefundeerde assumpties, in inzicht nodig in hoe opsporingsmethoden in de praktijk worden toegepast en hoe regulering in diezelfde praktijk 
uitwerkt. Een dergelijk inzicht vereist, in ieder geval wanneer (voldoende) voorafgaand empirisch onderzoek ontbreekt, een open, meer kwalitatieve benadering en het gebruik van verschillende databronnen, zoals opsporingsdossiers, interviews en jurisprudentie. ${ }^{179}$

\section{Discussie: het gebruik van opsporingsdossiers voor onderzoek}

Opsporingsdossiers waren een belangrijke databron voor de empirische studies die ten grondslag liggen aan dit proefschrift. Het gebruik van politiegegevens voor onderzoeksdoeleinden kent bepaalde beperkingen. De meest fundamentele beperking betreft het feit dat de onderzoeker voor de selectie van personen (verdachten) en onderwerpen afhankelijk is van processen binnen de politie. Een opsporingsdossier is het resultaat van veel keuzes en factoren die buiten de invloedssfeer van de onderzoeker liggen: de keuze van de dader of de criminele groepering waarop de politie zich richt; de keuze van de in te zetten opsporingsinstrumenten; de keuze van onderwerpen waarop de informatieverzameling zich richt; of de politie al dan niet succesvol is bij het verzamelen van die informatie; en hoe de resultaten van de informatieverzameling worden opgeschreven in het dossier. Uiteindelijk hebben opsporingsdossiers alleen betrekking op personen en activiteiten die onder de aandacht van de politie kwamen en waarover de politie informatie wilde en kon verzamelen. Dit kan leiden tot een vertekening in de onderzoeksuitkomsten. Activiteiten van daders die buiten het zicht vallen van de politie, blijven immers ook buiten beeld van de onderzoeker. Bovendien is de verslaglegging in een opsporingsdossier in zekere zin per definitie 'vertekend', het verzamelen van informatie en rapportage vindt immers plaats vanuit een strafrechtelijk perspectief.

Echter, vanuit het perspectief van een onderzoeker heeft het gebruik van opsporingsdossiers ook een belangrijk voordeel. Iedereen die zich wil verdiepen in criminele fenomenen, of het nu een onderzoeker is, een journalist of een politieambtenaar, wordt geconfronteerd met de 'muren van stilzwijgen' die criminele activiteiten omringen, vooral wanneer het om georganiseerde criminaliteit gaat (Van de Bunt, 2007, 2010). Alleen de politie echter heeft verregaande bevoegdheden om, via de inzet van opsporingsmethoden, door deze 'muren' heen te breken. Een onderzoeker die toegang heeft tot opsporingsdossiers profiteert van deze exclusieve bevoegdheden en kan zo een eveneens exclusief inzicht krijgen in de activiteiten van daders of in de wijze waarop zij zich tot elkaar en hun omgeving verhouden.

Een onderzoeker kan natuurlijk ook interviews afnemen bij daders en met hen praten over deze of andere onderwerpen, ervan uitgaande dat ze daartoe bereid zijn. Dergelijke interviews kunnen belangrijke inzichten opleveren (zie bijvoorbeeld Van Koppen, 2013; zie ook Bernasco, 2010) en zijn voor sommige onderzoeksdoeleinden misschien zelfs

179 Kwantitatieve benaderingen hebben eveneens belangrijke voordelen (evenals studies die zich bevinden aan het andere eind van het methodologische spectrum, etnographische ' $\mathrm{N}=1$ '-onderzoeken). Bepaalde aspecten van het beleid tegen georganiseerde criminaliteit zijn goed geschikt om onderzocht te worden met behulp van kwantitatieve onderzoeksmethoden (zie paragraaf S.4). 
noodzakelijk. Maar ook deze methode van dataverzameling kent zijn problemen. Hoe selecteer je bijvoorbeeld de respondenten, hoe krijg je hen bereid mee te doen aan het onderzoek en kan je hen zover krijgen om vrijuit en naar waarheid te vertellen. Een onderzoeker die toegang heeft tot bijvoorbeeld verslagen van afgeluisterde gesprekken tussen twee drugshandelaren, hoeft zich om deze problemen geen zorgen te maken. ${ }^{180}$ Ten aanzien van de methoden die de politie gebruikt om informatie te verzamelen, zijn verdachten een 'lijdend voorwerp'; de methoden worden ingezet zonder hun toestemming en in het geval van bijvoorbeeld afluisteren en undercoveroperaties ook zonder dat zij ervan op de hoogte zijn. Deze 'onopvallende' wijze van dataverzameling is erg waardevol voor het doen van onderzoek op een terrein dat anderszins weinig toegankelijk is.

De rol die opsporingsdossiers kunnen spelen voor onderzoeksdoeleinden is natuurlijk afhankelijk van de mate waarin onderzoekers toegang hebben tot deze bron, maar ook van de opsporingsmethoden die de politie gebruikt en van de mate waarin van de resultaten van die methoden verslag wordt gelegd. In relatieve zin is de Nederlandse politie vrij toegankelijk voor onderzoekers. Verder kent Nederland geen traditie van plea bargaining; personen die worden verdacht van serieuze strafbare feiten worden in beginsel voor de rechter gebracht, hetgeen de nodige dossiervorming met zich meebrengt. Bovendien moet de Nederlandse politie verslag doen (proces-verbaal opmaken) van de methoden die zijn ingezet en van de bevindingen die daarmee zijn verkregen. Deze verslagen vormen onderdeel van het opsporingsdossier.

\section{S.3 Implicaties}

Welke mogelijke implicaties hebben onze empirische resultaten voor het beleid ten aanzien van georganiseerde criminaliteit? Hierop gaan we in drie aparte paragrafen in. In paragraaf S.3.1 richten we ons op de aansturing en transparantie van de opsporing. Paragraaf S.3.2 concentreert zich op de investeringen van daders in de legale economie. In de laatste paragraaf (S.3.3) bespreken we de implicaties ten aanzien van de opsporing en het afpakken van criminele verdiensten.

\section{S.3.1 Aansturing en transparantie van de opsporing}

De huidige Nederlandse wetgeving met betrekking tot het gebruik van bijzondere opsporingsbevoegdheden is tot stand gekomen in de nasleep van de IRT-affaire. Deze affaire, die twintig jaar geleden plaatshad, draaide om opsporingsteams die 'experimentele' opsporingsmethoden toepasten in de strijd tegen de georganiseerde criminaliteit. Deze

180 Hoewel dit voorbeeld zelf al aantoont dat daders ook wanneer zij onder elkaar zijn goede redenen kunnen hebben om niet vrijuit te praten. 
speciale operaties werden uitgevoerd zonder (adequaat) toezicht en bovendien, aangezien zij geen expliciete basis hadden in het Wetboek van Strafvordering, in een wettelijk vacuüm. De Parlementaire Enquêtecommissie Opsporingsmethoden (PEO) die werd ingesteld naar aanleiding van de IRT-affaire, concludeerde dat er sprake was van een 'crisis in de opsporing' (PEO, 1996, Eindrapport; zie hoofdstuk 1). Het rapport dat de commissie uitbracht heeft aan de basis gelegen van de Wet bijzondere opsporingsbevoegdheden (Wet $\mathrm{BOB}$ ), die in 2000 van kracht is geworden. De Wet BOB kent drie uitgangspunten. Ten eerste dienen bijzondere opsporingsmethoden een expliciete wettelijke basis te hebben, dat wil zeggen dat ze 'gedekt' moeten worden door specifieke secties in het Wetboek van Strafvordering. Wat betreft undercoveroperaties maakt de Wet BOB onderscheid tussen drie verschillende bevoegdheden. Ten tweede versterkt de Wet BOB de rol van de officier van justitie. De officier van justitie heeft de formele leiding over het opsporingsonderzoek; hij beslist over de inzet van opsporingsmethoden. Ten derde moet de inzet van opsporingsmethoden controleerbaar en dus transparant zijn; van het gebruik van opsporingsmethoden moet verslag worden gemaakt en in beginsel moeten de gebruikte bevoegdheden in het openbaar ter terechtzitting worden verantwoord (Beijer et al, 2004: 277-278; Bokhorst et al., 2002: 185-186; Kleemans, 2007: 164-165; Kruisbergen en De Jong, 2010: 37-42).

De introductie van de Wet $\mathrm{BOB}$ past binnen een bredere, internationale trend. De laatste decennia zijn in verschillende landen instrumenten en maatregelen ingevoerd ter versterking van de greep op politieactiviteiten (Cockcroft en Beatty, 2009; Hale et al., 2004; Newburn et al., 2007: 547-548; Neyroud en Disley, 2007: 552; Terpstra, 2011). Zo is de opsporing in toenemende mate onderworpen aan formele regelgeving. Dit is gebeurd in landen met een continentaal rechtsstelsel, zoals België en Nederland, maar ook in landen waar ze het gewoonterecht (common law) als rechtsstelsel hebben, zoals Engeland en Wales (Conway en Walsh, 2011: 241-242; De Roy en Van Dromme, 2004; Kruisbergen, Kleemans et al., 2012; Roberts, 2007: 97-102; Traest en Meese, 2000). Dankzij wetgeving is de uitvoering van undercoveroperaties, voorheen een 'geheim en ongereguleerd' proces, aan strikte regulering onderworpen (Neyroud en Disley, 2007: 553). Behalve regulering met betrekking tot specifieke opsporingsmethoden zijn er ook andere, meer algemene ontwikkelingen die hebben bijgedragen aan een versterkte greep op, of aansturing van, politieactiviteiten. ${ }^{181}$ Centralisering (en standaardisering) is zo'n ontwikkeling. Zowel de Nederlandse politie als het Openbaar Ministerie heeft een zekere mate van centralisering doorgemaakt en er bestaan verschillende aanwijzingen en standaarden voor de opsporing (zie ook Hale et al., 2004; Terpstra, 2011: 101; Terpstra en Van der Vijver, 2005; Van de Bunt en Kleemans, 2007: 163-166, 182; Van de Bunt, 2004: 711-712; Jongeneel-Van Amerongen,

181 Neyroud en Disley merkten met betrekking tot de sturing van de opsporing in het Verenigd Koninkrijk op dat 'iedere rol (is) gedefinieerd, iedere activiteit geregistreerd en voor iedere beslissing is rekenschap verschuldigd' (Neyroud en Disley, 2007: 568). 
1997: 62-63). Het toegenomen belang van performancemanagement (prestatiesturing) is een andere ontwikkeling wat betreft de sturing van de opsporing (Neyroud en Disley, 2007: 558-561). Met de opkomst van performancemanagement werden publieke taken, waaronder de politie, beschouwd als bedrijfsmatige processen; de uitvoering moet efficiënt zijn en er dient verantwoording over te worden afgelegd (Manning, 2008: 284). Om (op basis van) de prestaties te kunnen sturen, worden politieactiviteiten afgemeten aan de hand van (onder andere) kwantitatieve resultaten. ${ }^{182}$

Regulering, prestatiesturing en centralisering (en standaardisering) van politieactiviteiten zijn instrumenten die dienen (onder andere) ter rationalisering van iets dat, voor zover het de opsporing betreft, in werkelijkheid heel complex is en in zekere zin 'rommelig' verloopt (Neyroud en Disley, 2007: 553). De inbreuken op mensenrechten die politieactiviteiten met zich mee kunnen brengen rechtvaardigen pogingen om die activiteiten te rationaliseren en aan te sturen. Zeker bij controversiële opsporingsmethoden als undercoveroperaties is de behoefte aan rationalisering en sturing sterk. ${ }^{183}$ Dankzij de Wet BOB zijn opsporingsmethoden als undercoveroperaties onderworpen aan specifieke voorschriften in het Wetboek van Strafvordering, waardoor het vacuüm waarin de politie opereerde voor de introductie van de wet is opgevuld. Bovendien heeft de Wet BOB de transparantie van het gebruik van opsporingsmethoden vergroot en de autoriteit van de officier van Justitie versterkt (Beijer et al., 2004; Bokhorst et al., 2002). Echter, niet ieder aspect van wetgeving en andere instrumenten die de greep op de opsporing moeten versterken is perfect afgestemd op de uitvoeringspraktijk. Ten eerste sluiten gedetailleerde regulering en de daarin gehanteerde onderscheiden niet altijd aan op de uitvoeringspraktijk. De uitvoering van de undercoverbevoegdheid waarvoor de wetgever de minst zware voorwaarden heeft opgesteld, het stelselmatig inwinnen van informatie, kan in de praktijk meer ingrijpend zijn dan de uitvoering van de undercoverbevoegdheid waarvoor de zwaarste voorwaarden gelden, infiltratie (hoofdstuk 2). Ten tweede kunnen gecentraliseerde autorisatieprocedures officieren van justitie afschrikken en daarmee wellicht onbedoelde gevolgen hebben (hoofdstuk 3). Ten derde botst het prospectief toetsen op subsidiariteit in zekere mate met de fundamentele onvoorspelbaarheid die kenmerkend is voor onderzoeken naar georganiseerde criminaliteit (hoofdstuk 3). Ten vierde zou beargumenteerd kunnen worden dat het complexe en

182 In 2003 introduceerde de Nederlandse overheid prestatiecontracten waarin meetbare resultaten waren opgenomen die die regionale politie-eenheden moesten behalen. In 2007 veranderde de opzet; er werd minder nadruk gelegd op kwantitatieve indicatoren. Lokale politie-eenheden, aldus Terpstra, behielden intern echter vaak streefwaarden voor de 'productie' (Terpstra, 2011: 91-96). Bovendien spelen kwantitatieve prestatieindicatoren, met betrekking tot het aantal aangepakte criminele samenwerkingsverbanden en de hoeveelheid geld die van daders wordt afgepakt, een belangrijke rol in het door het Openbaar Ministerie en de politie uitgedragen beleid tegen de georganiseerde criminaliteit (Openbaar Ministerie en Politie, 2015).

183 Volgens Walsh en Conway (2011: 61) is de opkomst van proactieve opsporingsmethoden een van de oorzaken van de toegenomen aandacht voor vraagstukken rondom (onder andere) de aansturing van de politie. 
onvoorspelbare karakter van onderzoeken naar georganiseerde criminaliteit zich ook slecht verhoudt tot de toegenomen behoefte aan stuurbaarheid die gepaard kan gaan met prestatiesturing. ${ }^{184}$

Gezien het ingrijpende karakter van politieactiviteiten is het gerechtvaardigd deze te willen reguleren en aan te sturen, zoals we al eerder aangaven. Bovendien betekent het feit dat bijvoorbeeld de Wet BOB en autorisatieprocedures in sommige gevallen tot ongewenste uitkomsten kunnen leiden, niet dat deze instrumenten als zodanig inadequaat zijn. Onze resultaten laten wel zien dat de opsporingspraktijk onvoorspelbaar en complex is en minder stuurbaar dan instrumenten als regulering, autorisatieprocedures en prestatiesturing zouden kunnen doen vermoeden. De opsporing, en met name de opsporing van georganiseerde criminaliteit, zal waarschijnlijk onderwerp van debat blijven. Deze debatten zouden zich niet moeten richten op een eventuele verdere versterking van de (illusie van) directe sturing van het opsporingsproces. Eerder zou ingezet moeten worden op vergroting van de transparantie van de opsporing, waarschijnlijk het meest essentiële uitgangspunt van de Wet BOB. Opsporingsonderzoeken zijn maar in beperkte mate stuurbaar, maar ze kunnen en moeten wel controleerbaar en evalueerbaar zijn.

\section{Transparantie}

Vanzelfsprekend kan het opsporingsproces nooit volledig transparant zijn, en dat geldt des te meer voor methoden als undercoveroperaties. Echter, de transparantie zou wel vergroot kunnen worden (Walsh en Conway, 2011: 71; Kruisbergen, Kleemans et al., 2012). De Wet BOB heeft de transparantie ten aanzien van het gebruik van opsporingsmethoden zeker vergroot. De wet schrijft voor dat verslag wordt gemaakt van de methoden die zijn gebruikt in een opsporingsonderzoek en in beginsel moeten deze methoden in het openbaar ter terechtzitting worden verantwoord (Beijer et al, 2004: 277-278). Voor de introductie van de Wet BOB waren rechters vaak niet eens op de hoogte van het feit dat een undercoveroperatie was ingezet (Van Traa, 1997: 16). Een evaluatie van de Wet BOB liet zien dat Nederlandse rechters tevreden zijn met de verslaglegging van en het geboden inzicht in het gebruik van opsporingsmethoden (Beijer et al., 2004: 282), hetgeen ook naar voren kwam bij het bestuderen van gerechtelijke beslissingen ten aanzien van undercoveroperaties (hoofdstuk 2). Transparantie heeft echter niet alleen betrekking op het inzicht dat gerechtscolleges wordt geboden. Opsporingsmethoden zouden ook onderwerp moeten zijn van andere soorten van kritische evaluatie, anders dan vanuit een zuiver juridisch perspectief in een specifieke zaak, zoals het geval is bij de strafrechter.

184 Ons eigen empirisch onderzoek richtte zich niet op de toepassing van performance management (prestatiesturing) ten aanzien van de opsporing. Voor een overzicht van de mogelijke neveneffecten van sturing op output, zie, bijvoorbeeld, Van Thiel en Leeuw, 2002 (zie ook Cockcroft en Beattie, 2009; Garland, 2002: 119-120; Pollitt, 1993; Ross, 2007: 520-521). 
Opsporingsmethoden, en wanneer het om georganiseerde criminaliteit gaat ook de andere instrumenten die tegen dit fenomeen worden ingezet, zouden het onderwerp van debat moeten zijn, en dat zijn ze ook. Helaas is echter zowel het academische als het parlementaire debat voor een belangrijk deel gebaseerd op normatieve standpunten en onbeproefde veronderstellingen, simpelweg omdat empirische informatie niet voldoende aanwezig is. In de huidige situatie is er in Nederland vrijwel geen openbare informatie die een basaal inzicht geeft in de uitvoering van undercoveroperaties. Recentelijk, mei 2016, heeft een krant informatie gepubliceerd over het aantal uitgevoerde undercoveroperaties in drie verschillende jaren. Deze krant ontving deze informatie na een beroep op de Wet openbaarheid van bestuur (WOB) (zie paragraaf S.2.1). In het algemeen is echter informatie als het aantal en de soort van undercoveroperaties die worden ingezet, het type misdrijven waarbij dat gebeurt en de resultaten die ermee worden behaald, niet beschikbaar. Hetzelfde geldt voor veel andere opsporingsmethoden. Bovendien is onderzoek naar hoe en wanneer bepaalde opsporingsmethoden worden gebruikt en hoe regulering in de praktijk uitwerkt schaars.

Een grotere kennis zou een sterkere fundering bieden voor het debat. Ook zou een sterkere empirische fundering regelgevende organen beter in staat stellen toezicht te houden op het gebruik van opsporingsmethoden en, wanneer nodig, goedgeïnformeerde besluiten te nemen. De kwaliteit van regelgeving kan daarvan profiteren. Om een dergelijke empirische fundering mogelijk te maken, moet informatie over de genoemde onderwerpen op regelmatige basis worden gegenereerd en toegankelijk gemaakt. Bovendien zouden criminologen vaker moeten kiezen voor - en worden toegelaten tot - de opsporingspraktijk als onderzoeksterrein.

De affaire die leidde tot het instellen van de Parlementaire Enquêtecommissie Opsporingsmethoden (PEO), en uiteindelijk tot introductie van de Wet BOB, speelde zich grofweg twintig jaar geleden af. Vanwege haar grondige onderzoek kon deze commissie het parlementaire debat van informatie voorzien. De transparantie die dankzij het werk van de commissie tot stand werd gebracht zou, tot op zekere hoogte, gecontinueerd moeten worden en zou niet afhankelijk moeten zijn van een 'affaire' of van specifieke verzoeken om informatie.

\section{S.3.2 Misdaadgeld en de legale economie}

In hoofdstuk 4 concludeerden we dat een theoretische benadering van georganiseerde criminaliteit die de nadruk legt op de sociale gelegenheidsstructuur goed bruikbaar is om de investeringen van daders in de legale economie te verklaren. De keuzes die een dader maakt bij het investeren worden bepaald en beperkt door de mogelijkheden die hij vindt in zijn directe sociale omgeving. Een benadering die de nadruk legt op de sociale gelegenheidsstructuur bleek meer geschikt om de gevonden investeringen te beschrijven dan een economische benadering of een criminele-infiltratiebenadering. Onze 'verwerping' 
van de economische, of misschien moeten we zeggen economistische, benadering, betekent natuurlijk niet dat we ervan uitgaan dat daders geen winst zouden willen maken wanneer zij hun geld investeren in de legale economie. Evenmin betekent het afwijzen van de criminele-infiltratiebenadering dat de investeringen van daders volstrekt irrelevant zijn wat betreft invloed en macht in de reguliere samenleving. Hoewel macht in het algemeen misschien niet de belangrijkste drijfveer is wanneer daders hun geld investeren, zouden deze investeringen uiteindelijk wel kunnen leiden tot een zekere mate van invloed, zeker wanneer een dader of criminele groepering voor langere tijd buiten het bereik van de politie blijft. Het voorkomen dat daders bepaalde posities verkrijgen in de reguliere samenleving is dan ook wel degelijk een van de redenen waarom het opsporen en afpakken van criminele verdiensten belangrijk is.

Onze analyse van investeringen van daders, evenals andere studies, lieten zien dat onroerend goed een belangrijke investeringscategorie is (Webb en Burrows, 2009: 27; Matrix Knowledge Group, 2007: 39; Malm en Bichler, 2013). Voor een dader heeft investeren in onroerend goed verschillende voordelen. Ten eerste wordt onroerend goed vaak beschouwd als een veilige en renderende investering. Ten tweede kan onroerend goed, vanwege het prijsniveau, veel geld absorberen. Ten derde is de prijsvorming van onroerend goed weinig transparant. Een vierde voordeel ligt in de mogelijkheid om het eigendom van onroerend goed af te schermen. Ten vijfde hebben ook criminelen, net als andere mensen, een plek om te wonen nodig (Soudijn en Akse, 2012; WEF, 2011: 9-11; Van Gestel, 2010; KLPD, 2008: 141; Kruisbergen, Van de Bunt et al., 2012: 214). ${ }^{185}$ De vastgoedmarkt is ook voor de legale economie van groot belang. Dat betekent dat het moeilijk kan zijn om effectieve maatregelen te nemen tegen de instroom van misdaadgeld in de vastgoedmarkt die niet tegelijkertijd ook raken aan de belangen van legale actoren. Het kan echter de moeite lonen om toch te investeren in dergelijke maatregelen en om het zicht van autoriteiten op onroerend goed (verder) te versterken. ${ }^{186}$

\section{S.3.3 Het opsporen en ontnemen van uit misdaad afkomstig vermogen}

Sinds de ontnemingswetgeving van kracht werd, zijn er verschillende maatregelen genomen om de wettelijke mogelijkheden voor ontneming te verruimen. Deze maatregelen kwamen vaak voort uit de behoefte om gepercipieerde problemen ten aanzien van de bestaande

185 Een nadeel van investeringen in onroerend goed, in ieder geval wanneer daadwerkelijk bijvoorbeeld een woning wordt aangekocht in plaats van vastgoedgerelateerde financiële producten, is dat het geld letterlijk vastzit, vooral in een periode waarin het aantal transacties sterk is gedaald (Soudijn, 2011: 44-45).

186 Recentelijk zijn (worden) er verschillende maatregelen ontwikkeld die de kwetsbaarheid van de vastgoedmarkt ten aanzien van witwassen moeten beperken. Op het moment dat dit proefschrift werd afgerond (zomer 2016), was het nog niet duidelijk hoe deze maatregelen, zoals de implementatie van de vierde EU-anti-witwasrichtlijn (Directive (EU) 2015/849), uitwerken (zie ook Minister van Veiligheid en Justitie, 2016). 
wetgeving of de uitvoering daarvan te verhelpen. Soms lijkt een dergelijk initiatief echter meer geïnspireerd door verontwaardiging over behaalde resultaten, dan door een inzicht in de uitvoeringspraktijk van ontnemingen (zie ook Borgers en Simmelink, 2005b; Borgers et al., 2007). Het parlementaire debat rondom ontneming lijkt soms te suggereren dat de uitval in ontnemingszaken vooral wordt veroorzaakt door wetgeving of toepassing van die wetgeving die te soepel is voor een veroordeelde.

Een voorbeeld hiervan is wetgeving die januari 2015 van kracht is geworden. ${ }^{187}$ Deze wijziging van de ontnemingswetgeving is bedoeld om de aftrek van kosten bij het bepalen van de hoogte van het te ontnemen bedrag in te perken. De wetsgeschiedenis laat zien dat er verontwaardiging was over het feit dat in sommige zaken rechters bij het bepalen van criminele verdiensten rekening houden met kosten die een veroordeelde heeft gemaakt. Hoewel de memorie van toelichting bij de ontnemingswetgeving zoals die in 1993 is ingevoerd expliciet de mogelijkheid van kostenaftrek noemt (Tweede Kamer, 1989-1990, 21 504, nr. 3: 16), hetgeen verder is uitgewerkt in jurisprudentie die sindsdien is ontstaan, lijkt de aftrek van kosten te worden gezien als een ten onrechte verleende gunst aan veroordeelden. De wetswijziging die januari 2015 is ingegaan is bedoeld om deze gepercipieerde onevenwichtigheid in de uitvoering van de ontnemingsmaatregel te herstellen (Tweede Kamer, 2011-2012, 29 911, nr. 56, 57; Tweede Kamer, 2012-2013, 33 685, nr. 3; Kooijmans en Borgers, 2012).

De vraag is echter of de probleemanalyse achter dit wetsvoorstel een juiste is. De gewijzigde wetgeving zelf wijkt op het punt van kostenaftrek niet af van hetgeen in de praktijk in ontnemingszaken al gebeurde; kostenaftrek is alleen onder bepaalde voorwaarden mogelijk. De wijziging lijkt daarmee wat overbodig, ware het niet dat de toelichting bij de wetgeving duidelijk maakt dat deze is bedoeld om tot een beperking van kostenaftrek te komen (Kooijmans en Borgers, 2012; Borgers en Simmelink, 2005b). Bovendien lijkt het oordeel dat de huidige rechtspraak op dit punt te soepel of onevenwichtig is, niet zozeer de uitkomst van een grondige analyse van de rechtspraak, maar vooral een uiting van de mening dat kostenaftrek bij ontnemingen op zichzelf verkeerd is. Het uitgangspunt dat wetgeving zoals deze lijkt in te geven, namelijk dat veroordeelden er 'te gemakkelijk vanaf komen', vertroebelt het zicht op de uitvoeringspraktijk.

In hoofdstuk 5 beargumenteerden we dat de uitval in ontnemingszaken waarschijnlijk samenhangt met de wijze waarop criminele verdiensten worden vastgesteld in de rechtspraktijk. Wat betreft de uitval gedurende de rechtsgang in ontnemingszaken gaat het dan vooral om de fundamentele onbepaaldheid van het 'wederrechtelijk verkregen voordeel' (criminele verdiensten), waardoor er in concrete zaken veel ruimte is voor uiteenlopende

187 Wet van 19 november 2014 tot wijziging van het Wetboek van Strafrecht, het Wetboek van Strafvordering en de Wet op de economische delicten met het oog op het vergroten van de mogelijkheden tot opsporing, vervolging, alsmede het voorkomen van financieel-economische criminaliteit (verruiming mogelijkheden bestrijding financieel-economische criminaliteit), Stb. 2014, nr. 445. 
zienswijzen op waar dat voordeel precies uit bestaat. Ook bij de uitval die plaatsvindt gedurende de incasso van ontnemingsmaatregelen speelt hoe criminele verdiensten worden bepaald in het recht en de praktijk een rol. Juist omdat het uitgavenpatroon van een veroordeelde en verliezen gedurende criminele transacties gedeeltelijk niet worden meegenomen bij het vaststellen het te ontnemen bedrag, zullen veroordeelden een ontnemingsmaatregel niet altijd volledig kunnen voldoen. ${ }^{188}$

Het beleid en debat rondom het afpakken van criminele verdiensten zou meer gevoed moeten worden door pragmatisme, feiten en analyse. Aan beleidsvoorstellen rondom dit thema is er geen gebrek. Zowel het beleid als het debat kan profiteren van een beter inzicht in de uitvoeringspraktijk van het opsporen en afpakken van criminele verdiensten alsook van een heldere analyse van de te bereiken doelen, de daarbij in te zetten instrumenten en de op te lossen knelpunten. Toekomstig debat rondom de financiële aanpak van georganiseerde criminaliteit zou (onder andere) van de volgende vertrekpunten uit moeten gaan.

Ten eerste is financiële recherche veel meer dan een noodzakelijke voorwaarde voor het afpakken van criminele verdiensten. Het debat lijkt erg gericht op het 'afpakken', maar opsporing met een financiële invalshoek heeft een veel breder nut voor de bestrijding van criminaliteit. Zo kan financieel rechercheren nieuwe verdachten in beeld brengen, informatie opleveren over de verblijfplaats en bewegingen van verdachten en het kan inzicht verschaffen in de rol die verschillende verdachten binnen een samenwerkingsverband spelen (Brown et al., 2012: 5-9; Levi, 2013; zie ook Slot et al., 2015). Ook kunnen in kaart gebrachte geldstromen bijdragen aan het bewijs dat een dader een achterliggend delict heeft gepleegd. Zo kan bijvoorbeeld in een geval van mensenhandel of afpersing de overdracht van geld van een slachtoffer naar een verdachte bijdragen aan de verdenking tegen laatstgenoemde (Nationaal Rapporteur Mensenhandel en Seksueel Geweld tegen Kinderen, 2014: 145-146). ${ }^{189}$

188 Uitval wordt ook veroorzaakt door het feit dat (sommige) daders (een deel van) hun vermogen verborgen weten te houden. Het opsporen en afpakken van vermogen wordt bijvoorbeeld bemoeilijkt doordat een deel van de vermogensbestanddelen zich in het buitenland bevindt (hoofdstuk 4). Een sterkere internationale samenwerking zou de opsporing en ontneming van deze buitenlandse vermogensbestanddelen ten goede komen.

189 Een element van het financieel rechercheren dat zeker niet wordt onderschat, misschien eerder het tegenovergestelde, is de financiële opbrengst die het genereert. Van investeringen in de financiële aanpak wordt verwacht dat ze resulteren in grote stijgingen van het afgepakte vermogen. Financieel rechercheren wordt verondersteld zichzelf terug te verdienen, en (veel) meer dan dat. Of de financiële baten van de financiële aanpak ook daadwerkelijk de kosten overstijgen, is echter maar helemaal de vraag, zoals onderzoek in het Verenigd Koninkrijk indiceert (Levi, 2013: 10; Sproat, 2009; Collins en King, 2013; Bullock, 2014: 63) (de kosten-batenratio zal bovendien ook sterk variëren tussen de verschillende instrumenten die worden gebruikt om vermogen af te pakken, zoals in deze subparagraaf ook wordt toegelicht). Financiële winst is ook niet het enige en misschien ook niet het meest belangrijke oogmerk van het afpakken van criminele verdiensten. Behalve het bekrachtigen van het normatieve standpunt dat misdaad niet mag lonen, kan het een ook rol spelen bij het voorkomen van toekomstige misdrijven. Het feit dat ontnemingsmaatregelen niet volledig worden geïncasseerd, betekent namelijk niet dat zij - laat staan andere instrumenten - volledig falen in het bereiken van de gewenste effecten. Er wordt via deze en andere instrumenten immers wel degelijk vermogen afgepakt van daders en je mag veronderstellen dat dat op zijn minst enige uitwerking op hen heeft. 
Ten tweede moet in het debat rondom de financiële aanpak het onderscheid tussen de verschillende instrumenten om geld af te pakken in ogenschouw worden genomen. Het afpakken van criminele verdiensten lijkt in het debat nogal eens als een homogene activiteit te worden gezien. De potentiële kosten en baten en de toepasbaarheid van instrumenten als de ontnemingsmaatregel, schikkingen en inbeslagnames van contant geld, verschillen echter sterk.

Kijken we naar de kosten en baten van het 'afpakken', dan zien we dat de totale waarde van het afgepakte vermogen de laatste jaren fors is toegenomen. In de periode 2012-2015 is het gezamenlijke resultaat van ontnemingsmaatregelen, schikkingen (en transacties), en inbeslagnames en verbeurdverklaringen, sterk gestegen: $€ 50$ miljoen in 2012, $€ 90$ miljoen in $2013, € 136$ miljoen in 2014 en $€ 144$ miljoen in 2015. In 2012 leverde de incasso van ontnemingsmaatregelen $€ 19,6$ miljoen op, bijna $40 \%$ van de totale waarde aan afgepakt vermogen. In 2015 werd er weliswaar voor $€ 22,8$ miljoen aan ontnemingsmaatregelen geïncasseerd, maar dit vertegenwoordigde nog maar bijna $16 \%$ van de totale waarde aan afgepakt vermogen. De indrukwekkende toename van het afgepakte vermogen is in belangrijke mate toe te schrijven aan een klein aantal zaken van zogenoemde witteboordencriminaliteit die met een schikking en/of transactie zijn afgedaan. Zo werd in 2013 door de First Curaçao International Bank N.V. (FCIB), die was veroordeeld wegens overtreding van regelgeving voor financiële instellingen, een regeling getroffen met het OM waarbij de bank $€ 35$ miljoen betaalde. In 2015 betaalde SBM offshore $€ 61$ miljoen als onderdeel van een regeling naar aanleiding van betrokkenheid bij omkooppraktijken (Minister van Veiligheid en Justitie, 2013, 2015; Openbaar Ministerie, 2014, 2015, 2016; data van het CJIB, niet gepubliceerd). Een andere relevante factor bij de toename van het afgepakte vermogen is de aandacht die de politie besteedt aan ondergronds bankieren en geldkoeriers, welke resulteert in de inbeslagname van aanzienlijke hoeveelheden contant geld (Openbaar Ministerie en Politie, 2015). Het Openbaar Ministerie kiest ervoor om een deel van deze zaken niet via een gang naar de rechter maar via een transactie te regelen, vooral wanneer het om zogenoemde 'first offenders' gaat. In dergelijke gevallen moet de betreffende persoon, behalve dat hij of zij het aangetroffen contante geld verliest, een aanvullend geldbedrag betalen.

De zaken van witteboordencriminaliteit die we zojuist bespraken en de acties die zich richtten op de geldkoeriers (de 'first offenders' onder hen), werden afgedaan zonder een gang naar de rechter. Via het treffen van een regeling werd voorkomen dat het 'afpakken' onderwerp werd van langdurige gerechtelijke procedures, zoals bij ontnemingsmaatregelen het geval kan zijn. Bovendien verloopt de incasso in deze zaken relatief gemakkelijk: de betrokken partijen stemmen immers in met betaling (en ze betalen ook (zie de cijfers over de afdoening van schikkingen in Minister van Veiligheid en Justitie, 2015)). Voor de koeriers geldt bovendien nog dat de inbeslagname van hun geld vaak samenvalt met 
hun aanhouding. ${ }^{190}$ Wanneer het om de verhouding tussen financiële kosten en baten van 'afpakken' gaat, zullen schikkingen en transacties, en inbeslagnames, waarschijnlijk dan ook efficiënter zijn dan ontnemingsmaatregelen. Efficiëntie is echter niet het enige en misschien ook niet het meest belangrijke criterium. Zoals gezegd verschillen de instrumenten om criminele verdiensten af te pakken ook van elkaar wat betreft hun toepasbaarheid. Schikkingen zijn bijvoorbeeld alleen mogelijk in zaken waarin zowel het Openbaar Ministerie als de dader(s) willen (en kunnen) schikken (betalen). Verder is het in beslag nemen van geld vanzelfsprekend alleen mogelijk in zaken waarin contant geld is te vinden. Het onderscheid tussen de verschillende instrumenten, wat betreft hun toepasbaarheid en de mogelijke kosten en baten, moet een uitgangspunt zijn van het debat over de financiële aanpak. ${ }^{191}$

Een derde - en het meest essentiële - vertrekpunt voor toekomstig debat rondom de financiële aanpak van georganiseerde criminaliteit is dat moet worden nagedacht over wat we willen bereiken met die aanpak. Zojuist zijn we ingegaan op de grote verschillen tussen de instrumenten die worden gebruikt om criminele verdiensten af te pakken. Als het doel is om een zo hoog mogelijke afpakopbrengst te realiseren tegen de laagst mogelijke kosten, dan zijn schikkingen en transacties, en inbeslagnames, misschien meer geschikte instrumenten dan ontnemingsmaatregelen. Als daarentegen het uitgangspunt is dat in ieder geval geprobeerd moet worden om iedere met criminaliteit verdiende euro af te pakken, dan moet geaccepteerd worden dat de financiële kosten daarvan hoger zouden kunnen zijn dan de opbrengsten. In plaats van het afpakken van criminele verdiensten, zou ook de bestrijding en preventie van georganiseerde criminaliteit als belangrijkste doel van de financiële aanpak kunnen worden aangemerkt. Dit zou deels tot weer andere keuzes kunnen leiden wat betreft de invulling van deze aanpak, keuzes die bij voorkeur zijn gebaseerd op inzicht in de financiële aspecten van verschillende typen van georganiseerde criminaliteit.

190 Dit geldt natuurlijk niet voor het aanvullende bedrag dat ze moeten betalen.

191 Mei 2015 heeft de Minister van Veiligheid en Justitie een overzicht van de afpakresultaten naar de Tweede Kamer gestuurd waarin onderscheid wordt gemaakt tussen de verschillende instrumenten (Minister van Veiligheid en Justitie, 2015). 


\section{S.4 Onderzoek naar de bestrijding van georganiseerde criminaliteit}

Ten slotte bespreken we het nut en de mogelijke invulling van toekomstig onderzoek naar de bestrijding van georganiseerde criminaliteit.

\section{S.4.1 Waarom is onderzoek naar de bestrijding van georganiseerde criminaliteit nodig?}

Waarom zouden we onderzoek doen naar bestrijding van georganiseerde criminaliteit? Het wetenschappelijke belang van een onderzoek hangt af van de mate waarin het empirische informatie genereert ten aanzien van onderzoeksvragen die nog niet afdoende zijn behandeld. Het hangt ook af van de mate waarin een onderzoek bijdraagt aan het theoretische begrip van het onderwerp in kwestie. Zo bezien is het niet moeilijk om te pleiten voor meer onderzoek naar bestrijding van georganiseerde criminaliteit, simpelweg omdat empirisch onderzoek relatief schaars is. Veel vragen zijn nog onvoldoende beantwoord. Deze vragen raken onderwerpen als: de gemaakte keuzes, gebruikte methoden en behaalde resultaten in opsporingsonderzoeken naar georganiseerde criminaliteit; hoe daders de financiële aspecten van hun activiteiten afhandelen; en de interactie tussen verschillende interventies tegen georganiseerde criminaliteit enerzijds en het opereren van daders anderzijds.

Behalve op basis van het wetenschappelijk belang kan onderzoek ook worden beoordeeld op grond van maatschappelijk belang. Zal onderzoek naar interventies tegen georganiseerde criminaliteit leiden tot meer arrestaties en veroordelingen? Zal het resulteren in betere afpakresultaten? Zulke directe effecten zouden niet het oogmerk of de rechtvaardiging van onderzoek op dit terrein moeten vormen. Medewerkers van politie en het Openbaar Ministerie weten hoe zij criminelen moeten vangen (Kleemans, 2014a). De maatschappelijke relevantie van onderzoek naar interventies tegen georganiseerde criminaliteit is primair gelegen in het verschaffen van een empirische basis voor het debat, beleid en de democratische controle. De uitkomsten van dit proefschrift indiceren dat sommige impliciete assumpties onder het academische en/of politiek-maatschappelijke debat wel eens onjuist kunnen zijn en dat regulering soms tot ongewenste uitkomsten kan leiden. Dit betekent niet dat het beleid faalt of dat betrokkenen bij het debat incompetent zouden zijn. Vanwege het gebrek aan empirische informatie is het simpelweg onvermijdelijk dat beleid en debat met betrekking tot georganiseerde criminaliteit berusten op ongefundeerde assumpties. Dat is dan ook precies de reden waarom empirisch onderzoek zo belangrijk is (Kleemans, 2014a; zie ook Leeuw, 2003, 1991).

\section{S.4.2 Suggesties voor verder onderzoek}

Wat betreft undercoveroperaties zou toekomstig onderzoek zich onder andere moeten richten op het online toepassen van deze opsporingsmethode. Het internet biedt zowel 
criminelen als opsporingsorganisaties kansen. Het internet biedt criminelen bijvoorbeeld de mogelijkheid om klanten, mededaders en slachtoffers te bereiken die anders misschien buiten bereik zouden blijven. Evenzo kunnen politieambtenaren de mogelijkheden benutten om online dekmantelidentiteiten op te bouwen. Het online uitvoeren van undercoveroperaties raakt ook aan het vraagstuk van transparantie, aangezien de online interacties tussen een undercoveragent en een subject in beginsel relatief eenvoudig geregistreerd kunnen worden. Hoe worden deze mogelijkheden in de praktijk gebruikt, verschilt de dynamiek van online interacties tussen undercoveragenten en hun subjecten van interacties in de offline wereld en spelen er specifieke risico's wanneer undercoveragenten online opereren?

Empirisch onderzoek naar het gebruik van opsporingsmethoden is relatief schaars. Tot nu is een aantal studies verricht naar het gebruik van specifieke opsporingsmethoden, zoals undercoveroperaties (de voorliggende studie; Kruissink et al., 1999) en de telefoontap (Odinot et al., 2012; Reijne et al., 1996). Het afluisteren van face-to-face gesprekken en het gebruik van kroongetuigen zijn twee andere methoden die, vanwege hun ingrijpendheid, de veronderstelde risico's die aan deze methoden verbonden zijn en/of omdat ze aanleiding geven tot debat, het verdienen onderwerp te zijn van grondig onderzoek (zie Beune en Giebels, 2013). Er zijn echter meer relevante aspecten in een opsporingsonderzoek dan de keuze van de te gebruiken opsporingsmethoden. Politieambtenaren en officieren van justitie moeten in onderzoeken naar georganiseerde criminaliteit verschillende andere keuzen maken: wie zijn de belangrijkste verdachten; hoeveel verdachten moeten in het onderzoek worden meegenomen; moet het onderzoek zich vooral richten op leidende figuren, uitvoerende verdachten en/of facilitators; en moet de inzet van opsporingsmiddelen gericht zijn op het vergaren van zoveel mogelijk bewijs met betrekking tot de meest ernstige criminele activiteiten, of moet het doel zijn om zo snel als mogelijk (via aanhoudingen bijvoorbeeld) in te grijpen? Case studies kunnen een licht werpen op hoe deze en andere keuzen worden gemaakt en daarmee ons begrip van het opsporingsproces vergroten (zie ook De Poot et al., 2004). Zulke studies zouden zich specifiek moeten richten op de mate waarin het verloop van een opsporingsonderzoek wordt bepaald door strategische en tactische overwegingen van het opsporingsteam dan wel door factoren die buiten de invloedsfeer van het team liggen, zoals gebeurtenissen in het criminele milieu. Dit raakt aan wat misschien wel een van de meest interessante vragen is op dit terrein: hoe verloopt de interactie tussen daders enerzijds en de door de autoriteiten ingezette tegenmaatregelen anderzijds (zie bijvoorbeeld Spapens, 2006)? Het bestuderen van interactie impliceert min of meer dat een onderzoeker zijn onderzoekssubjecten voor een bepaalde periode volgt. Hierdoor is de genoemde onderzoeksvraag behalve interessant ook moeilijk te behandelen. Echter, het gebruik van data zoals verslagen van telefoontaps, afgeluisterde face-to-face gesprekken, observaties en verhoren, zou antwoorden kunnen genereren op meer specifieke vragen als hoe anticiperen daders op politieactiviteiten, hoe reageren ze op inbeslagnames en aanhoudingen van mededaders, en hoe aanpasbaar is hun modus operandi? 
Met betrekking tot de financiële aanpak zijn er eveneens nog veel onderwerpen die nog niet voldoende zijn onderzocht. Zo is empirisch onderzoek naar waar daders hun verdiensten aan besteden nog relatief schaars. Zowel kwalitatieve als kwantitatieve methoden kunnen (en moeten) gebruikt worden om tot een hoger niveau van kennis te komen. Kwalitatief onderzoek is nodig om inzicht te verschaffen in de mechanismen en overwegingen die een rol spelen bij hoe daders in de georganiseerde criminaliteit hun geld besteden. Om dat inzicht te krijgen, zou geprobeerd moeten worden om informatie te krijgen van hen die hier het meeste over weten, de daders zelf (zie bijvoorbeeld Matrix Knowledge Group, 2007; Webb en Burrows, 2009). Het gebruik van deze databron zou ten dele ook een tegenwicht kunnen bieden aan de mogelijke vertekening die samengaat met het gebruik van opsporingsdossiers, hoewel het interviewen van daders natuurlijk weer zijn eigen problemen met zich meebrengt. De door kwalitatief onderzoek verkregen inzichten kunnen op hun beurt een basis vormen voor kwantitatieve analyses van opsporingsdossiers en databestanden van in beslag genomen goederen. Dergelijke analyses zouden zich kunnen richten op de aard, omvang en plaats van investering en op eventuele verschillen op deze punten tussen daders.

Witwasmethoden vormen een ander onderwerp van onderzoek dat aandacht verdient, en dan met name digitale witwasmethoden. Het gebruik van bijvoorbeeld bitcoin voor witwasdoeleinden roept interessante vragen op. Wat doen daders met hun via misdaad verkregen bitcoins; zetten ze deze bitcoins vooral om in traditionele munteenheden of wordt een deel ervan als bitcoin bewaard of uitgegeven? Hebben bitcoingerelateerde witwasdiensten vooral betrekking op de omwisseling van bitcoins voor traditionele munteenheden, of werkt dit ook de andere kant op, dat wil zeggen daders die bijvoorbeeld hun via criminele wijze verkregen euro's omzetten in bitcoins? Welke problemen brengt het gebruik van bitcoin voor daders met zich mee? Heeft het criminele gebruik van deze betaalmethoden ook geleid tot nieuwe soorten facilitators?

Ten slotte zouden onderzoekers zich moeten richten op het vergroten van het inzicht in de praktijk en de resultaten van het opsporen en afpakken van criminele verdiensten (zie hoofdstuk 5). De financiële aanpak is gebaseerd op de veronderstelling dat het afpakken van hun verdiensten daders het meeste 'pijn' doet. Toch weten we erg weinig over de effecten van deze aanpak. Hoe en in welke mate worden daders en hun criminele activiteiten geraakt door het 'afpakken'? Verschillende methoden kunnen worden gebruikt om dit vraagstuk te benaderen. Zo kan via kwantitatieve analyses worden onderzocht of de recidive verschilt tussen daders die respectievelijk wel en niet financieel zijn 'aangepakt'. Kwalitatief onderzoek kan op zijn beurt bijdragen aan een groter begrip van hoe financiële interventies uitwerken. Het bestuderen van bijvoorbeeld door de politie afgeluisterde gesprekken tussen daders, en het interviewen van daders, kan licht werpen op hoe daders anticiperen en reageren op die interventies. 


\section{S.4.3 Afsluitende opmerkingen}

In het voorafgaande pleitten we voor meer onderzoek en transparantie aangaande de bestrijding van georganiseerde criminaliteit. Meer onderzoek en transparantie zal leiden tot een grondiger inzicht in hoe interventies tegen georganiseerde criminaliteit in de praktijk uitwerken. Dat maakt het op zijn beurt beter mogelijk om rationeel te discussiëren over dit onderwerp. Dit moet niet verward worden met een pleidooi voor verdere rationalisering van politieactiviteiten in de zin van meer regulering en meer sturing. Een groter inzicht in hoe beleid tegen georganiseerde criminaliteit in de praktijk uitpakt, zou voor sommigen inderdaad aanleiding kunnen zijn om nieuwe of aangepaste regulering in gang te zetten. Voor anderen echter kan een dergelijk inzicht reden geven om zijn of haar beeld van de 'georganiseerde criminaliteit' aan te passen of om kritische kanttekeningen te plaatsen bij bestaande beleidstheorieën. Wat met kennis wordt gedaan is geheel aan beleidsmakers en andere betrokkenen bij het debat over georganiseerde criminaliteit. Het is de taak van de onderzoeker om te voorzien in een basis voor dat debat.

Recentelijk wordt meer nadruk gelegd op de maatschappelijke relevantie en valorisatie van onderzoek. In beginsel is het, vergeleken met andere terreinen van onderzoek, niet moeilijk om de potentiële maatschappelijke waarde te benoemen van onderzoek naar aan criminaliteit gerelateerde onderwerpen. Daarbij kan je al snel het argument aantreffen dat meer kennis leidt tot een effectiever criminaliteitsbeleid en dus tot minder criminaliteit. Werkend vanuit dit perspectief richt onderzoek zich dan nogal eens op het in kaart brengen van what works en best practices. De maatschappelijke waarde van onderzoek dat er daadwerkelijk in slaagt om antwoord te geven op vragen naar welke maatregelen het meest effectief zijn in het verminderen van criminaliteit, staat buiten kijf. Een eenzijdige nadruk op wat werkt, gaat echter voorbij aan een voorliggende vraag die, gegeven het huidige niveau aan empirische kennis, misschien essentiëler is: Hoe werkt het? 


\section{Curriculum vitae}

Edwin William Kruisbergen was born in The Hague, the Netherlands, on the $30^{\text {th }}$ of June 1971. He obtained his masters degree in Sociology at the Erasmus University Rotterdam in 1997, where he specialized in Methods and Statistics in Social Sciences, and Labour and Social Security Studies. Between 1997 and 2004 he worked as a researcher at the Social Security Supervisory Board (Ctsv), the Institute for Research on Public Expenditure (IOO), and the Institute of Sociological-Economic Research (ISEO) at the Erasmus University Rotterdam. In those years, his research focused on implementation and results of social security and labour market policies, and immigrant integration. In 2004 he started working at the Research and Documentation Centre (WODC) of the Dutch Ministry of Security and Justice. At the WODC, he focused on organized crime and methods of criminal investigation. He coordinates the Dutch Organized Crime Monitor, an ongoing systematic analysis of police files on organized crime in the Netherlands. So far, 150 cases were analysed, which will add up to 180 when the fifth data sweep is finished (2017). Furthermore, he did research on money laundering, the confiscation of criminal earnings, drug smuggling through Amsterdam Schiphol Airport, the use of DNA in criminal investigations, and undercover police operations. 


\section{Publications}

Kruisbergen, E.W. (in press). When other methods fail... Infiltrating organized crime groups in the Netherlands. In J.M. Nelen and D. Siegel (eds.), Contemporary organized crime: developments, challenges and responses (preliminary title). Dordrecht/Norwell, Massachusetts: Springer.

Kruisbergen, E.W., Kleemans, E.R. and Kouwenberg R.F. (2016). Explaining attrition: Investigating and confiscating the profits of organized crime. European Journal of Criminology, DOI: $10.1177 / 1477370816633262$.

Kruisbergen E.W., Kleemans E.R. and Kouwenberg R.F. (2015). Profitability, power, or proximity? Organized crime offenders investing their money in legal economy. European Journal on Criminal Policy and Research, 21(2): 237-256.

Kruisbergen, E.W. and Soudijn, M.R.J. (eds.) (2015). Themanummer Misdaadgeld, witwassen en ontnemen. Justitiële Verkenningen, 41(1).

Kruisbergen, E.W. and Soudijn, M.R.J. (2015). Inleiding. Justitiële Verkenningen, 41(1): 5-9.

Kruisbergen, E.W. and Soudijn, M.R.J. (2015). Wat is witwassen eigenlijk? Introductie tot theorie en praktijk. Justitiële Verkenningen, 41(1): 10-23.

Kruisbergen, E.W., Kleemans, E.R. and Kouwenberg, R.F. (2015). Wat doen daders met hun geld? Uitkomsten van de Monitor Georganiseerde Criminaliteit. Justitiële Verkenningen, 41(1): 84102.

Kruisbergen, E.W. (2014). Annual meeting of the American Society of Criminology, Atlanta. Een verslag. Centre for Information and Research on Organized Crime (CIROC) Nieuwsbrief, 14(1): $5-6$.

Kruisbergen, E.W. (2014). Book review. Fijnaut, C. (2014). Criminology and the administration of criminal law. Centre for Information and Research on Organized Crime (CIROC) Newsletter, August 2014: 3-4.

Kleemans, E.R., Kruisbergen, E.W. and Kouwenberg, R.F. (2013). Women, brokerage and transnational organized crime. Empirical results from the Dutch Organized Crime Monitor. Trends in Organized Crime, 17(1): 16-30.

Kruisbergen, E.W. (2013). Infiltrating organized crime groups. Theory, regulation and results of a last resort method of investigation. Cahier Politiestudies, 2013-3/28: 109-136.

Kruisbergen, E.W., Kleemans, E.R. and Van de Bunt, H.G. (2013). Georganiseerde criminaliteit in Nederland. Centre for Information and Research on Organized Crime (CIROC) Nieuwsbrief, 13(1): 3-4.

Kruisbergen, E.W., Kleemans, E.R. and Van de Bunt, H.G. (2013). Organized Crime Monitor. Centre for Information and Research on Organized Crime (CIROC) Newsletter, August 2013: 3-4.

Kruisbergen, E.W. and De Jong, D. (2012). Undercoveroperaties: een noodzakelijk kwaad? Heden, verleden en toekomst van een omstreden opsporingsmiddel. Justitiële Verkenningen, 38(3): 50-67.

Kruisbergen, E.W., Kleemans, E.R. and De Jong, D. (2012). Controlling Criminal Investigations: The Case of Undercover Operations. Policing, A Journal of Policy and Practice, 6(4): 398-407. 
Kruisbergen E.W., Van de Bunt, H.G. and Kleemans, E.R. (2012). Georganiseerde criminaliteit in Nederland. Vierde rapportage op basis van de Monitor Georganiseerde Criminaliteit. Meppel: Boom Lemma Uitgevers.

Kruisbergen, E.W., Croes, M. and Flap, H. (2011). Tekenen voor de Waffen-SS: Wie en waarom? Een aanzet tot een historisch sociologisch onderzoek. In G. Kraaykamp, M. Levels and A. Need (eds.), Problemen en Theorieën in Onderzoek. Een staalkaart van de hedendaagse Nederlandse empirisch-theoretische sociologie (331-343). Assen: Koninklijke Van Gorcum b.v.

Kruisbergen, E.W., De Jong, D. and Kleemans, E.R. (2011). Undercover Policing: Assumptions and Empirical Evidence. British Journal of Criminology, 51(1): 394-412.

De Jong, D. and Kruisbergen, E.W. (2010). Opsporen onder dekmantel. Centre for Information and Research on Organized Crime (CIROC) Nieuwsbrief, 10(1): 4-5.

Kruisbergen, E.W. and De Jong, D. (2010). Opsporen Onder Dekmantel: Regulering, Uitvoering en Resultaten van Undercovertrajecten. Meppel: Boom Juridische Uitgevers.

Kruisbergen, E.W. and De Jong, D. (2010). Undercovermethoden na de Wet BOB. Openheid over een verborgen opsporingsinstrument. Nederlands Juristenblad, 85(6): 341-347.

Kruisbergen, E.W. (2008). Afname DNA bij veroordeelden leidt tot steeds grotere databank. Centre for Information and Research on Organized Crime (CIROC) Nieuwsbrief, 8(2): 3-4.

Kruisbergen, E.W. (2008). Van vonnis tot DNA-profiel. Procesevaluatie van de Wet DNA-onderzoek bij veroordeelden. Den Haag: WODC, Cahiers 2008-02.

Kruisbergen, E.W. and De Poot, C.J. (2007). Toepassing van DNA-wetgeving in de praktijk: nog veel onbeantwoorde vragen. Nederlands Juristenblad, 82(28): 1728-1735.

Kruisbergen, E.W. and De Poot, C.J. (2006). Kringen rond de dader. Grootschalig DNA-onderzoek als instrument in de opsporing. Centre for Information and Research on Organized Crime (CIROC) Nieuwsbrief, 6(3): 2.

Kruisbergen, E.W. and Croes, M.T. (2006). Verdeelde belangen: vergrijzing en de multi-etnische samenleving. Justitiële Verkenningen, 32(3): 42-54.

De Poot, C.J. and Kruisbergen, E.W (2006). Kringen rond de dader. Grootschalig DNA-onderzoek als instrument in de opsporing. Meppel: Boom Juridische Uitgevers, Den Haag: WODC.

Kruisbergen, E.W. (2005). Voorlichting: doen of laten? Theorie van afschrikwekkende voorlichtingscampagnes toegepast op de casus van bolletjesslikkers. Beleidswetenschap, 19(3): $38-51$.

Kruisbergen, E.W. (2004, 2005). Confidential reports on drug smuggling (not publicly available).

Kruisbergen, E.W. and Veld, Th. (2004). Inleiding. In ISEO en COS, Minderhedenmonitor 2003: Integratie en inburgering in Rotterdam (1-12). Rotterdam: ISEO/COS.

Kruisbergen, E.W. and Veld, Th. (2004). Integratie en inburgering: het beleid. In ISEO en COS, Minderhedenmonitor 2003: Integratie en inburgering in Rotterdam (13-30). Rotterdam: ISEO/ COS. 
Distelbrink, D., Ergun, C., Geense, P., Kruisbergen, E.W., Veld, Th. and Van der Zanden, W. (2003). Conclusies en aanbevelingen. In ISEO and COS, Minderhedenmonitor 2002: Etnische minderheden in Rotterdam (203-220). Rotterdam: ISEO/COS.

Kruisbergen, E.W. (2003). Inleiding. In ISEO and COS, Minderhedenmonitor 2002: Etnische minderheden in Rotterdam (1-4). Rotterdam: ISEO/COS.

Kruisbergen, E.W. (2003). Diversiteit bij de Bestuursdienst. In ISEO and COS, Minderhedenmonitor 2002: Etnische minderheden in Rotterdam (117-162). Rotterdam: ISEO/COS.

Kruisbergen, E.W. and Van der Zanden, W. (2003). Demografie en huisvesting. In ISEO and COS, Minderhedenmonitor 2002: Etnische minderheden in Rotterdam (5-34). Rotterdam: ISEO/COS.

Dominguez Martinez, S., Groeneveld, S. and Kruisbergen, E.W. (2002). Integratiemonitor 2002. Rotterdam: ISEO/EUR.

Fris, P., Kruisbergen, E.W. and Hof, H. (2002). Heroriëntatie Toekomstscenario's WUBO, WUV en $W P B$. Zoetermeer: IOO.

Kruisbergen, E.W. and Veenman, J. (2002). Arbeid en inkomen. In J. Veenman (ed.), De toekomst in meervoud. Perspectief op multicultureel Nederland (85-114). Assen: Van Gorcum.

Kruisbergen, E.W. and Veld, Th. (2002). Een gekleurd beeld. Over beelden, beoordeling en selectie van jonge allochtone werknemers. Assen: Van Gorcum.

Kruisbergen, E.W., Kok, L.M. and Ten Broeke, L. (2001). Ontwikkelingen in de Wajong. Amsterdam: Lisv.

Cordia, L.A.J., Buurman, M.W.J.M., Kruisbergen, E.W. and Lucas, A. (2001). De kunst van het aanbesteden. Onderzoek naar werking van de aanbestedingsprocedure bij inkoop van reïntegratieactiviteiten. R01/01. Zoetermeer: Ctsv.

Buurman, M.W.J.M., Kok, L.M., Kruisbergen, E.W. and Van Ingen, D.C. (2000). Tussen Gak en Arbeidsvoorziening. De dienstverlening aan arbeidsgehandicapten voor en na de fusie. Zoetermeer: IOO.

Kruisbergen, E.W. and Hof, A. (2000). Toekomstscenario's voor aanspraken op de WUBO, WUV en de WBP. Zoetermeer: IOO.

Cordia, L.A.J., Bosselaar, H. and Kruisbergen, E.W. (eds.) (1999). Augustusrapportage handhaving 1999. Trends en thema's in handhaving van sociale verzekeringen. Zoetermeer: Ctsv.

Doeschot, R.G.P., Fiseler, J.G., Houwen, R.J., Kruisbergen, E.W., Raadschelders, J.M.M. and Vijgen, J. (1999). Straffen met beleid. Uitvoering van de Wet boeten, maatregelen en terug- en invordering sociale zekerheid. Zoetermeer: Ctsv.

Cordia, L.A.J., Bosselaar, H., Kruisbergen, E.W., Lucas, A. and Nool, J.W. (1998). Augustusrapportage handhaving 1998. De stand van handhaving in de sociale verzekering. Zoetermeer: Ctsv. 